UNIVERSIDADE DE SÃO PAULO

FACULDADE DE FILOSOFIA, LETRAS E CIÊNCIAS HUMANAS

DEPARTAMENTO DE LETRAS MODERNAS

PROGRAMA DE PÓS-GRADUAÇÃO EM ESTUDOS LINGUÍSTICOS E LITERÁRIOS EM INGLÊS

HENRIQUE MATIUSSI FRANCO

ORIENTADORA: ELIZABETH HARKOT-DE-LA-TAILLE

Semiótica, intertextualidade e videogame

Versão corrigida

São Paulo

2020 
HENRIQUE MATIUSSI FRANCO

henrique.matiussi.franco@usp.br

\title{
Semiótica, intertextualidade e videogame
}

\author{
Versão corrigida
}

Dissertação apresentada ao Programa de Pós-Graduação em Estudos Linguísticos e Literários em Inglês do Departamento de Letras Modernas da Faculdade de Filosofia, Letras e Ciências Humanas da Universidade de São Paulo para a obtenção do título de Mestre em Letras.

Área de Concentração: Estudos Linguísticos e Literários em Inglês.

Orientadora: Prof. ${ }^{a}$ Dr. ${ }^{a}$ Elizabeth Harkotde-La-Taille

São Paulo 
Autorizo a reprodução e divulgação total ou parcial deste trabalho, por qualquer meio convencional ou eletrônico, para fins de estudo e pesquisa, desde que citada a fonte.

Catalogação na Publicação

Serviço de Biblioteca e Documentação

Faculdade de Filosofia, Letras e Ciências Humanas da Universidade de São Paulo

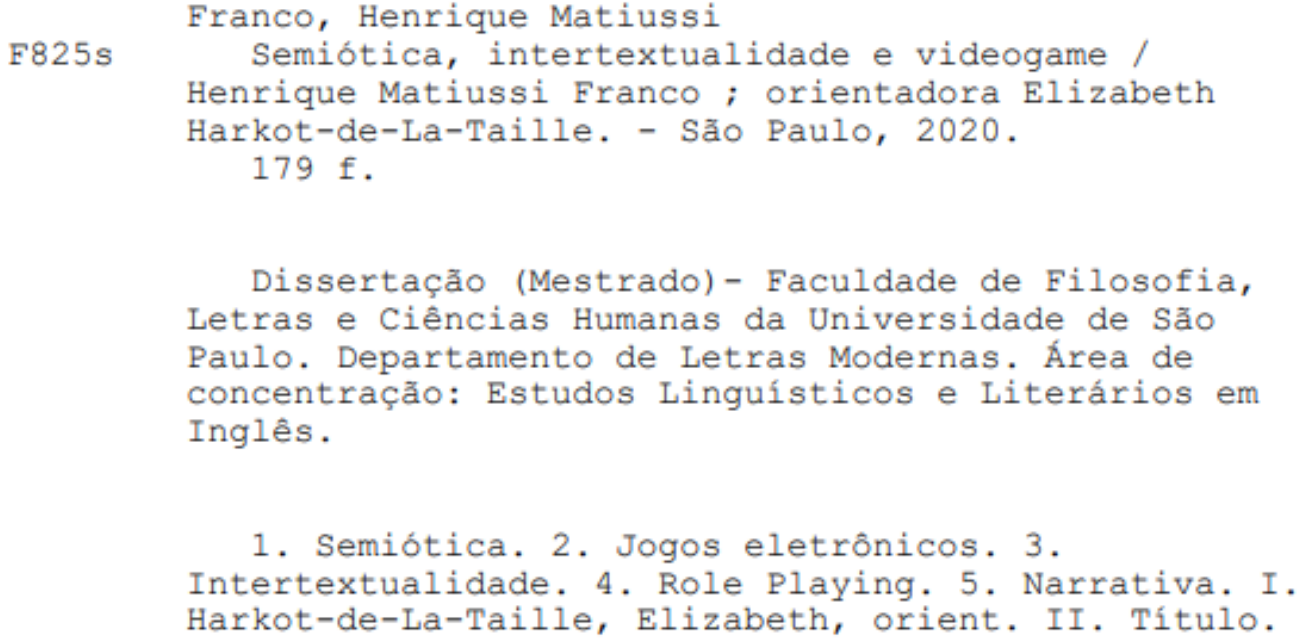


$\zeta^{n} \mathrm{C}$ CI $\mathrm{C}$ UNIVERSIDADE DE SÃO PAULO

FACULDADE DE FILOSOFIA, LETRAS E CIÊNCIAS HUMANAS

\section{ENTREGA DO EXEMPLAR CORRIGIDO DA DISSERTACCÃO/TESE}

Termo de Ciência e Concordância do (a) orientador (a)

Nome do (a) aluno (a): Henrique Matiussi Franco

Data da defesa: $13 / 03 / 2020$

Nome do Prof. (a) orientador (a): Elizabeth Harkot de La Taille

Nos termos da legislação vigente, declaro ESTAR CIENTE do conteúdo deste EXEMPLAR

CORRIGIDO elaborado em atenção às sugestões dos membros da comissão Julgadora na sessão de defesa do trabalho, manifestando-me plenamente favorável ao seu encaminhamento e publicação no Portal Diqital de Teses da USP.

São Paulo, 05/05/2020

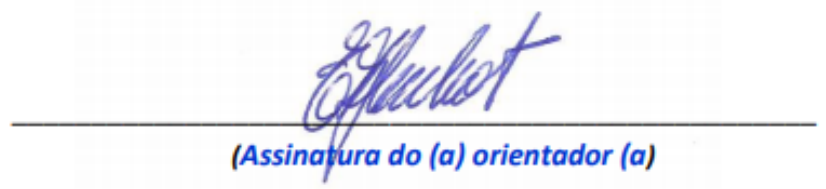


FRANCO, H. M. Semiótica, intertextualidade e videogame. Dissertação apresentada à Faculdade de Filosofia, Letras e Ciências Humanas da Universidade de São Paulo para obtenção do título de Mestre em Letras.

Aprovado em: 13/03/2020

\section{Banca Examinadora}

Prof. Dr. Instituição:

Julgamento: Assinatura:

Prof. Dr. Instituição:

Julgamento: Assinatura:

Prof. Dr. Instituição:

Julgamento: Assinatura: 
Para minha mãe, meu pai e minha irmã.

Vocês são as colunas que me sustentaram e me deram suporte para crescer até aqui. 


\section{Agradecimentos}

Aos meus pais, que sempre proporcionaram um apoio incondicional aos meus sonhos e estiveram junto a mim em todas as minhas conquistas, mas principalmente, nos momentos mais difíceis.

A Juliana, minha irmã, por todo o apoio, motivação e por ser a minha melhor amiga desde sempre.

À Faculdade de Filosofia, Letras e Ciências Humanas da Universidade de São Paulo, pela oportunidade da realização da Pós-Graduação.

À minha orientadora, Elizabeth Harkot-de-La-Taille, por todo o incentivo, enriquecimento cultural, conhecimento, apoio e, principalmente, pela paciência nesta minha jornada.

Aos membros da banca, pela leitura e comentários enriquecedores.

Às professoras Norma Discini e Renata Mancini, por terem participado da banca de Qualificação, cujos apontamentos, observações e sugestões foram fundamentais para o desenvolvimento desta Dissertação.

À minha querida Julia, por todo o apoio dado, desde antes de eu entrar no Programa de Pós-Graduação.

Ao Felipe, meu cunhado e grande irmão.

Ao Lucão, querido primo e irmão, pelas muitas conversas que constantemente trocamos, de domingo em domingo, sobre a vida universitária, um sempre incentivando o outro.

Aos meus queridos companheiros auxiliares de jovens da "velha guarda" Raphael Marchetto, Filipe Rocha e Felipe Corcovado.

Ao meu parceiro beletrista, poeta e grande amigo João Pedro.

Aos meus amigos Leonardo, Rodrigo, Victor, Daniela, Letícia, Rafa e Julião.

Aos companheiros auxiliares de jovens Jean, Matheus, Mayko e Pepê. 
Ao meu grande amigo Eric Muccio, companheiro de jornada desde o Ensino Fundamental até os assentos das salas de aula da FFLCH.

Aos estimados companheiros da Letras, também da mesa de RPG e grandes amigos Lucas Bento, Gustavo Martins, Igor Camargo e Rodrigo Kagan.

A Thaís Janoti, pelo apoio e pela maravilhosa tradução do artigo "Les parcours passionels de l'indifférence", fundamental para o desenvolvimento desta Dissertação.

Aos meus admiráveis colegas do GES-USP. Sempre vou me sentir uma formiguinha em meio à sua grandeza acadêmica. Vocês são inspirações.

Aos meus professores da graduação, principalmente ao Waldir Beividas, Antônio Vicente Seraphim Pietroforte e Ivã Carlos Lopes, por terem me apresentado a Semiótica e, por conseguinte, me instigado a tentar fazer Iniciação Científica.

Ao caríssimo Ronério Candian.

Ao meu amado avô Orlando Matiussi, exemplo de fé, persistência e humildade. 
- What are you making me choose now?

- Between the road to light and the road to darkness.

- Neither suits me. I'm taking the middle road.

- Do you mean the twilight road to nightfall?

- No. It's the road to dawn.

(Riku e Diz - Kingdom Hearts Re: Chain of Memories) 


\section{RESUMO}

FRANCO, Henrique Matiussi. Semiótica, intertextualidade e videogame. 2020. 179 f. Dissertação (Mestrado) - Faculdade de Filosofia, Letras e Ciências Humanas, Universidade de São Paulo, 2020.

Ancorados principalmente na teoria semiótica francesa (GREIMAS; COURTÉS, 2016; GREIMAS; FONTANILLE, 1993; ZILBERBERG, 2011), propomos, nesta Dissertação, investigar a maneira como o recurso da intertextualidade enriquece episódios narrativos presentes no enredo do jogo eletrônico The Witcher III: Wild Hunt. Escolhendo dentro de uma grande quantidade de missões presentes no jogo, procuramos comparar três variantes com seus textos-base, verificando se o recurso intertextual utilizado foi paráfrase, estilização, paródia ou polêmica, apoiados no estudo que Discini (2004) faz da intertextualidade no conto maravilhoso. Pela necessidade de contextualizar o objeto de estudo, mais precisamente, episódios narrativos de um videogame da geração atual de jogos eletrônicos do gênero RPG de ação, no primeiro capítulo desta pesquisa exploramos a origem do role playing game, mais precisamente, voltando a atenção para Dungeons \& Dragons, mundialmente conhecido. A partir daí, investigamos o conceito de jogo e como o RPG pode ser considerado “jogo" em si, também analisando sua adaptação para o meio eletrônico. Dentro do mesmo capítulo, por considerarmos pertinente, também é explorada a questão das estratégias enunciativas que compõem o RPG. No capítulo seguinte, voltamos o olhar para as raízes de The Witcher III: Wild Hunt, a série de livros escrita pelo polonês Andrzej Sapkowski, direcionando a atenção para algumas questões passionais que envolvem o protagonista Geralt de Rívia. A análise da intertextualidade se dá no Capítulo 3, onde inicialmente demonstramos exemplos de relações intertextuais presentes em textos da mídia contemporânea e, assim, debruçamo-nos sobre nosso principal objeto de estudo, demonstrando como a intertextualidade enriquece a narrativa de The Witcher III: Wild Hunt.

Palavras-chave: Semiótica, Intertextualidade, Jogos Eletrônicos. 


\begin{abstract}
FRANCO, Henrique Matiussi. Semiótica, intertextualidade e videogame. 2020. 179 f. Thesis (Master's) - Faculdade de Filosofia, Letras e Ciências Humanas, Universidade de São Paulo, 2020.

Based mainly on French semiotics (GREIMAS; COURTÉS, 2016; GREIMAS; FONTANILLE, 1993; ZILBERBERG, 2011), we propose to investigate how the resource of intertextuality enriches narrative episodes present on the plot of the electronic game The Witcher III: Wild Hunt. Choosing from a great variety of quests inside the game, we intend to compare three variants with their base text, verifying if the intertextual resource employed characterizes a paraphrasis, stylization, parody or polemics, supported by Discini's studies (2004) related to intertextuality in the wonder tale. By the necessity of contextualizing our object of study, precisely, narrative episodes from an action RPG video game from contemporary electronic games generation, in the first chapter of this research we explore the origins of the roleplaying game, more precisely, turning our attention to the worldly known Dungeons \& Dragons. Thenceforth, we investigate the concept of game and how RPG can be considered a "game" itself, also analyzing its adaptation to the electronic environment. In the same chapter, due to relevance, we also explore the matter of enunciative strategies that compose the RPG. In the following chapter, we turn our observation to the roots of The Witcher III: Wild Hunt, the series of books written by Polish writer Andrzej Sapkowski, directing our attention to some passional matters that involve the protagonist Geralt of Rivia. The analysis of intertextuality takes place in Chapter 3, where in the beginning we show examples of intertextual relations present in contemporary media texts and, then, we focus on our main object of study, demonstrating how the intertextuality enriches the narrative of The Witcher III: Wild Hunt.
\end{abstract}

Keywords: Semiotics, Intertextuality, Video Games. 


\section{LISTA DE FIGURAS}

Figura 1.1 - Tabela criada por Jesper Juul, indicando exemplos de JOGOS, CASOS FRONTEIRIÇOS (denominados por ele "quase-jogos") e NÃO JOGOS

Figura 1.2 - Colossal Cave Adventure (1976). As expressões ">s", ">n" e ">w" representam comandos que o jogador digitava para indicar ao "narrador-computador" em qual direção sua personagem se deslocava, respectivamente ">south", ">north" e ">west".

Figura 1.3 - Adventure (1979). O jogador comanda um quadrado (em frente ao portão do castelo) que deve explorar o cenário em busca de um cálice mágico. .45

Figura 1.4 - O clássico controlador do console Atari .46

Figura 1.5 - Criação de personagem em Dragon Age Origins .47

Figura 1.6 - Distribuição de pontos de atributos 47

Figura 1.7 - Legenda da cena diz: "Hoje, seu irmão mais velho assume o estandarte da Família Cousland em serviço à Coroa - não contra os homens de Orlais, mas contra os bestiais criassombrias que se erguem ao sul"....

Figura 1.8 - Após ser informado pelo pai que seu irmão mais velho marchará para batalha, o protagonista recebe quatro opções de escolha de frases para dar continuidade ao diálogo .49

Figura 1.9 - Zoom da Figura 1.8, focando na caixa de texto do jogo. O jogador pode optar por uma das seguintes falas para dar continuidade ao diálogo: 1. Você está certo? O que envolve uma tarefa como essa? / 2. Vou dar o meu melhor, Pai. / 3. O quê? Por que eu não posso marchar para a batalha com você e Fergus? / 4. Isso é mesmo necessário?

Figura 1.10 - The Witcher III: Wild Hunt (CD Projekt)........................... 51

Figura 1.11 - The Elder Scrolls V: Skyrim vivenciado em primeira pessoa...................53

Figura 1.12 - The Elder Scrolls V: Skyrim vivenciado em terceira pessoa....................54

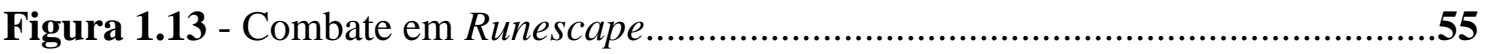


Figura 1.14 - Protagonista enfrentando um inimigo considerado "invencível"

Figuras 2.1 e 2.2 - Quadrado semiótico do sujeito......................................................61

Figura 2.3 - Interface de The Witcher III: Wild Hunt...............................63

Figura 2.4 - Os cinco sinais de The Witcher III: Wild Hunt .........................................64

Figura 2.5 - Menu de pausa de The Witcher 3: Wild Hunt............................66

Figura 2.6 - Mapa com marcadores de viagem rápida, representados por placas de

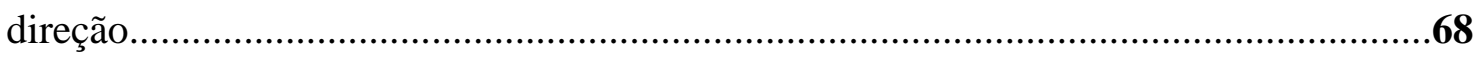

Figura 2.7 - Cifra tensiva. Adaptado de ZILBERBERG (2011)..................................74

Figura 2.8 - Geralt vê as atrocidades cometidas por Willy e diz: "Degenerado de merda. Se ele tiver tocado na Ciri, eu o mato."........................................................................86

Figura 2.9 - Cifra tensiva do acontecimento. Adaptado de ZILBERBERG (2011).......87

Figura 2.10 - Zoom da Figura 2.8. A mensagem "Mate o Filho da Puta Júnior" indica qual é o próximo passo para o jogador concluir a missão. .88

Figura 2.11 - Júnior não entende o que está acontecendo ao ver Geralt adentrando seu quarto, indagando "Que porra é isso?"

Figura 2.12 - Sem hesitar, Geralt golpeia Willy repetidamente................................90

Figura 2.13 - Depois de ser espancado, Willy ainda tenta fingir que não sabe do que se trata. .90

Figura 2.14 - Geralt se inclina e diz querer conversar. .91

Figura 2.15 - "Levei muito tempo para te encontrar. Não foi um caminho fácil. Estou furioso e cansado". Sujeito expressa seu descontentamento 91

Figura 2.16 - "Sinto que mais uma mentira seria a última gota em um cálice cheio de tristeza. E, então... então eu faria algo do qual me arrependeria." Sujeito ameaçando vingança. 
Figura 3.1 - Thor direciona a eletricidade conduzida por seu martelo à cúpula em que o androide meio humano está.

Figura 3.2 - O compartimento explode

Figura 3.3 - O homem-máquina se levanta de seu leito

Figura 3.4 - L (abaixo) enxuga os pés de Light.

Figura 3.5 - Beau Gray explica a situação para Arthur. "Eu a amo, sabe" diz. 103

Figura 3.6 - "Mas é impossível...". 103

Figura 3.7 - "Ela é uma Braithwaite". 104

Figura 3.8 - "Nós, Grays, temos sido leais ao Estado..." 104

Figura 3.9 - "e letais para os Braithwaite há tanto tempo...". 105

Figura 3.10 - "ninguém sabe explicar o porquê.". 105

Figura 3.11 - Arthur entrega a carta a Penelope. A jovem se queixa: "O resto das nossas famílias está preso na Idade das Trevas ou..."..... 106

Figura 3.12 - "não sei, talvez no tempo das cavernas.". 106

Figura 3.13 - "Noite estrelada sobre o Pontar", de Van Rogh. Quadro leiloado na narrativa de The Witcher III: Wild Hunt, fazendo alusão intertextual à pintura de Van Gogh 108

Figura 3.14 - "Noite estrelada sobre o Ródano", de Van Gogh. 109

Figura 3.15 - Quadrado semiótico do nível fundamental de Bela Adormecida. 112

Figura 3.16 - Programa narrativo do príncipe. 112

Figura 3.17 - Geralt (à esquerda), encontra Anabelle (mancha negra à direita), espectro que diz não ver a saída da torre

Figura 3.18 - Anabelle diz: "Ele me deu uma poção. Se eu fosse descoberta, eu devia bebê-la... Ele disse que tudo ficaria bem.”.

Figura 3.19 - "Que tipo de poção era? Lembra do cheiro, da aparência?" 115

Figura 3.20 - "Eu só lembro que fiquei com medo de beber.". 
Figura 3.21 - "Não confiou no mago?".

Figura 3.22 - "Na vila diziam que ele mexia com doenças. Não curando, mas causando. Disseram que ele atraía ratos para a torre, infectava-os com a Catriona.".

Figura 3.23 - "E então eu o ouvi, o meu amado Graham. Ele me chamou. Eu abri a porta, mas os outros correram para dentro. Eles se jogaram sobre mim e... e..."

Figura 3.24 - "Eram muitos. "Deixem ela em paz!", ele gritou. Ele tentou impedi-los, mas eles só riram...”.

Figura 3.25 - "Eles me pegaram pelos braços, rasgaram o meu vestido... Eu consegui fugir e beber a poção, e, então... nada.”

Figura 3.26 - "Eu acordei mais tarde. Estava sozinha. Estava escuro. Só que havia ratos por toda parte, dúzias, centenas. E eu não conseguia me mexer.".

Figura 3.27 - "Uma poção de sono. Os efeitos ainda não tinham passado. Você estava paralisada...".

Figura 3.28 - "Uma maldição gerada com ódio me prende a este lugar. Apenas o poder do amor poderia desfazê-la, mas... Quem amaria uma aparição?"

Figura 3.29 - "E o seu amado? Ele também está morto?"

Figura 3.30 - "Graham? Não. Ele vive. Eu saberia se ele estivesse morto, mas ele fugiu e me abandonou! Me deixou aqui sozinha!"

Figura 3.31 - "Uma maldição prendeu Anabelle e os demais espíritos na ilha. O amor pode desfazer esse poder e libertar a todos."

Figura 3.32 - Geralt avisa Graham que o beijo tem que ser de alguém cujo amor seja verdadeiro

Figura 3.33 - Graham diz amar Anabelle com todo o seu ser.

Figura 3.34 - A dama da peste pede a Graham que a beije

Figura 3.35 - O rapaz beija a monstruosidade e quebra a maldição

Figura 3.36 - Graham morre logo após o beijo.

Figura 3.37 - Quadrado semiótico do nível fundamental da história de Anabelle 126 
Figura 3.38 - PN de base de "Uma torre repleta de ratazanas"

Figura 3.39 - Programa narrativo de Graham

Figura 3.40 - Programa narrativo de Caim

Figura 3.41 - Programa narrativo de Abel

Figura 3.42 - Geralt pergunta aos camponeses: "O que estão fazendo aqui?".

Figura 3.43 - "O quê? Esse veio voando da lua? Estamos fazendo ofertas para o Deus Supremo, é claro!"....

Figura 3.44 - "Você também pode pedir a Sua ajuda. Quer dizer, se tiver ofertas adequadas. Ele rejeitou as nossas e amaldiçoou o vilarejo inteiro."

Figura 3.45 - "Então, o que há de errado com as suas oferendas?"

Figura 3.46 - "Não precisa debochar de nós. Pode ver bem que só trouxemos restos. Antes da guerra, não daria isto nem aos meus cães, mas o que podemos fazer? São os tempos."

Figura 3.47 - E eles vão piorar. O Deus Supremo disse que se não tiver uma tira de bacon e um barril de cerveja pelo menos, os rios se encherão de sapos, grilos e afins que devorarão as colheitas!".

Figura 3.48 - Geralt invoca ao deus dos camponeses: "Oh, Deus Supremo, ajude um pobre coitado necessitado, por favor."

Figura 3.49 - A voz abafada responde do altar: "Como ousa perturbar o meu descanso divino, mortal?!"

Figura 3.50 - "Eu ouso perturbar porque quero que vossa divindade desfaça a, ahm, maldição que lançou. Aqueles camponeses não têm...".

Figura 3.51 - "Eles devem trazer oferendas dignas ou todos enfrentarão uma seca! Geadas! Terremotos! Avalanches! Tenho dito!"

Figura 3.52 - O monstro indaga: "O quê? Quem ousa perturbar o meu ser divino?!".....138 
Figura 3.53 - Geralt satiriza o porte da criatura: "Esperava que o Deus Supremo fosse uma força corpórea, mas nunca esperei que fosse... corpulento. Você engordou bem por conta dos camponeses."

Figura 3.54 - "Não vai dizer nada sobre a ajuda que dei a eles, as bençãos, absolvições, conselhos? Creia-me, esse povo precisava disso tudo! Cuidaria deles ainda se eles cumprissem com os seus deveres, mas recentemente eles me oferecem essas migalhas patéticas...".

Figura 3.55 - "...Que eles roubam das bocas dos seus filhos. E, para piorar, você os amaldiçoou.". .140

Figura 3.56 - E eu não vou desfazer a maldição até me trazerem oferendas dignas! Tenho que me contentar com feijão e trigo? Sem chance. E pode dizer isso a eles!"

Figura 3.57 - "Tenho novidades. O seu deus está morto. Era só um monstro comum senciente, mas malvado, que tirou vantagem de vocês. Vocês passaram fome enquanto ele engordava."

Figura 3.58 - O camponês reage: "O que foi que você fez?! O Deus Supremo nos alertou. Ele disse que uma morte depravada nos aguardaria! Vamos, Trebor, devemos contar aos demais. Somente orações em grupo poderão nos salvar agora."

Figura 3.59 - Programa narrativo de "Um deus ganancioso"

Figura 3.60 - O aldeão explica a situação: "O bando da Chapeuzinho quer atacar o vilarejo. Ela quer vingança pelo Bertram. Não temos muito, mas estamos dispostos a pagar se nos defender."

Figura 3.61 - Geralt pergunta sobre a Chapeuzinho

Figura 3.62 - "Dizem que ela transa com lobos e que pode partir um homem em dois com as mãos! Uma fera em um corpo humano. Porém, alguns dizem que ela é bela."

Figura 3.63 - "Ela lidera um bando de desertores, lixo, de exércitos diferentes. Do tipo que sabe matar e pilhar.".

Figura 3.64 - "O bando da Chapeuzinho estava aterrorizando o nosso vilarejo. Não tínhamos quem nos defendesse. Então, Bertram falou com os caçadores e pediu a eles." 
Figura 3.65 - "Aí os caçadores foram atrás deles. Tivemos um tempo de paz, mas agora a Chapeuzinho ficou sabendo de tudo. Ela quer matar o Bertram. Ele já era se você não ajudar."

Figura 3.66 - Geralt indaga Chapeuzinho: "O que o Bertram fez que te faça querer vingança?" .154

Figura 3.67 - "Quer dizer que não mencionaram essa parte? Então, escute: ele veio até mim há meio ano. Disse que diria quem valia a pena roubar. Em troca, ele queria parte do que pegássemos."

Figura 3.68 - "Mas daí, depois de um tempo, o desgraçado ficou ganancioso. Queria mais, e eu recusei. Foi então que ele mandou os caçadores de bruxas para cima de nós. Perdi metade de meus homens por causa dele!" 155

Figura 3.69 - "Agora, saia do meu caminho, bruxo. Isto não é assunto seu. Queremos o Bertram e mais ninguém. Você tem a minha palavra" diz Chapeuzinho, determinada. .155

Figura 3.70 - "Não me importo muito com o que tenha a dizer. Pegue os seus homens e suma, ou teremos derramamento de sangue." frisa Geralt 156

Figura 3.71 - Chapeuzinho se transforma em um lobisomem (centro) 156 


\section{LISTA DE TABELAS}

Tabela 1 - Tabela de exemplos de temas e figuras no nível discursivo de "A bela adormecida no bosque". Autoria própria.. 113

Tabela 2 - Tabela com a comparação entre os temas e figuras dos textos, enfatizando as $\begin{array}{llll}\text { figuras } & \text { em } & \text { comum. } & \text { Autoria }\end{array}$

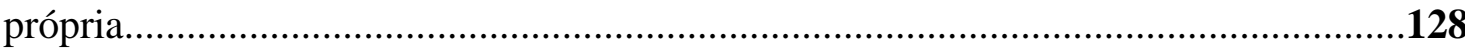


Introdução.

1. O RPG sob a lente da semiótica francesa.........................................................27

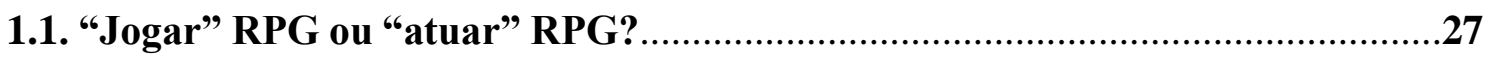

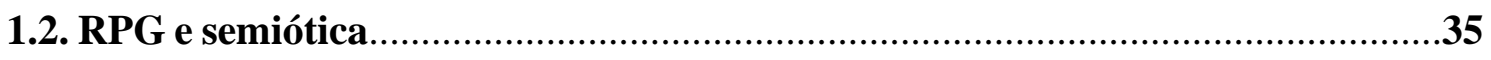

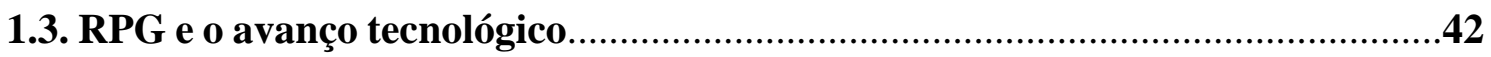

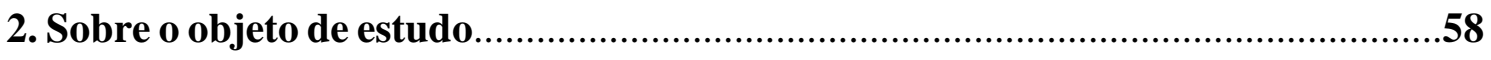

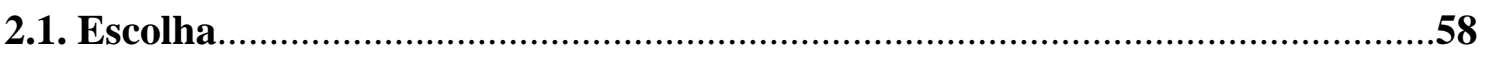

2.1.1. O que é The Witcher III: Wild Hunt ..................................59

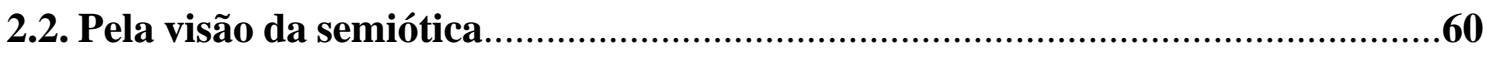

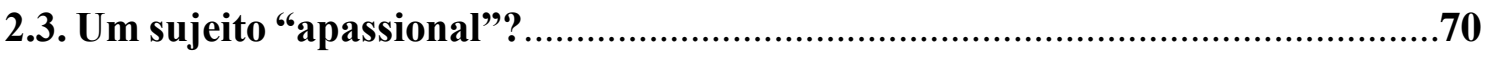

3. Intertextualidade em The Witcher III: Wild Hunt ............................94

3.1. Intertextualidade e as mídias ..........................................94

3.2. Análise da intertextualidade em The Witcher III: Wild Hunt ...........................108

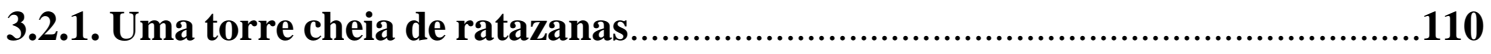

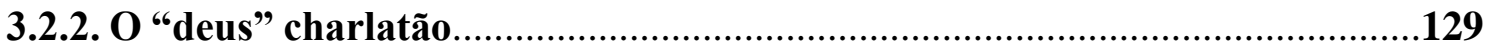

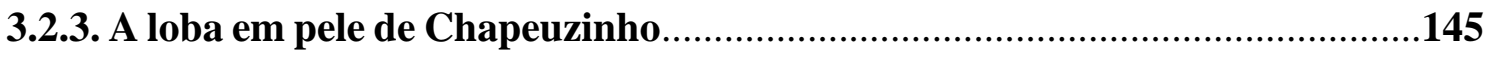

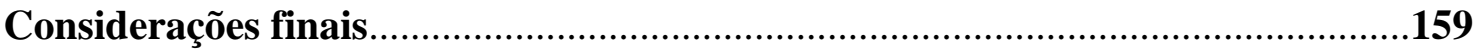

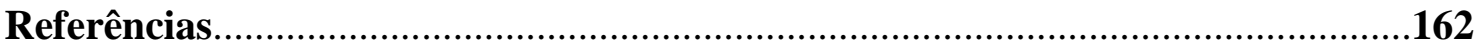

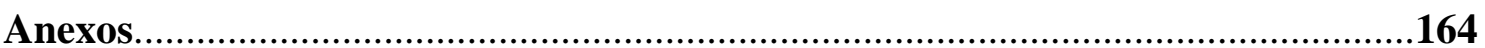




\section{Introdução}

$\mathrm{O}$ videogame tem conquistado cada vez mais espaço quando o assunto de discussão é o lazer. O produto que inicialmente era um grupo de dados de programação manifestados em pixels na tela de um monitor evoluiu em escala surpreendente para obras interativas de apresentação de nível artístico e narrativas complexas, de modo que a indústria dos jogos eletrônicos superou a do cinema, em questões de produção orçamentária e lucro ${ }^{1}$.

Tendo notado o avanço nas estratégias narrativas presentes nos jogos eletrônicos, optamos por considerar o videogame como texto, na definição da semiótica:

Considerado enunciado, texto opõe-se a discurso, conforme substância de expressão gráfica ou fônica - utilizada para a manifestação do processo linguístico. Segundo alguns linguistas (R. Jakobson), a expressão oral e, por conseguinte, o discurso, é anterior à escrita: esta seria apenas um derivado, uma tradução da manifestação oral. Para outros (L. Hjelmslev), pelo contrário, o ponto de vista genético não é pertinente, já que uma forma semiótica pode ser manifestada por diferentes substâncias.

Com frequência, o termo texto é tomado como sinônimo de discurso, o que acontece, sobretudo, em decorrência da interpretação terminológica com aquelas línguas naturais que não dispõem de equivalente para o termo francês. Nesse caso, semiótica textual não se diferencia, em princípio, de semiótica discursiva. Os dois termos - texto e discurso podem ser empregados indiferentemente para designar o eixo sintagmático das semióticas não linguísticas: um ritual, um balé podem ser considerados textos ou discursos. (GREIMAS, COURTÉS, 2016, p. 502-3, grifos nossos).

Considerando o jogo eletrônico como texto e, portanto, passível de análise semiótica, nesta Dissertação nos debruçamos sobre o título The Witcher III: Wild Hunt, o qual chamou-nos a atenção como objeto de estudo, não só pela grande quantidade de prêmios internacionais de reconhecimento recebidos, ou pela qualidade gráfica ou de jogabilidade, mas principalmente, pelas estratégias de enriquecimento da narrativa através da intertextualidade. Desta forma, buscamos, ancorados em Discini (2004), analisar a manifestação da intertextualidade em três dos muitos episódios narrativos

\footnotetext{
${ }^{1}$ https://www.correiobraziliense.com.br/app/noticia/diversao-earte/2015/07/30/interna_diversao_arte,492553/videogames-fazem-frente-a-poderosa-industriacinematografica.shtml, acesso em 21/01/2020.
} 
presentes no jogo. Para isso, baseamo-nos principalmente na teoria semiótica francesa, na qual foi desenvolvido o conceito de percurso gerativo de sentido, idealizado pelo Grupo de Paris.

Pelo percurso gerativo do sentido podemos depreender a produção do sentido por trás dos textos-base e das suas variantes e, então, colocá-los lado a lado para comparação. De acordo com a semiótica narratológica francesa, um texto seria composto por níveis, dos quais, um profundo, mais abstrato, chamado fundamental, um narrativo e um discursivo, mais concreto.

No nível fundamental analisamos quais são as oposições semânticas que fundamentam o texto, representadas por semas que são contrários (por exemplo, /natureza/ VS. /cultura/) e que também possuem equivalentes contraditórios (/nãocultura/, /não-natureza/). Para se analisar qual categoria semântica predomina no desenrolar do texto, utilizamos do quadrado semiótico.

Compreende-se por quadrado semiótico a representação visual da articulação lógica de uma categoria semântica qualquer. A estrutura elementar da significação, quando definida - num primeiro momento - como uma relação entre ao menos dois termos, repousa apenas sobre uma distinção de oposição que caracteriza o eixo paradigmático da linguagem: ela é, portanto, suficiente para constituir um paradigma composto de $n$ termos, mas não permite por isso mesmo distinguir, no interior desse paradigma, categorias semânticas baseadas na isotopia (o "parentesco") dos traços distintivos que nele podem ser reconhecidos. Faz-se necessária uma tipologia das relações, por meio da qual se possam distinguir os traços intrínsecos, constitutivos da categoria, dos traços que lhe são alheios. (Idem, p. 400)

Dessa forma, segundo o Dicionário de semiótica, para construirmos um quadrado semiótico com o intuito de analisar o nível fundamental de um texto, só podemos considerar categorias semânticas que sejam de um "mesmo parentesco" e cujos traços distintivos possam ser reconhecidos. Uma oposição entre os termos /vida/ e /morte/ é possível, já que se distinguem pelo traço "vida". Vida e morte são claramente opostas. Este mesmo tipo de oposição lógica já não seria possível com termos como /círculo/ e /triângulo/, por exemplo.

Após análises de muitos contos maravilhosos de Vladimir Propp, Greimas chegou ao esquema narrativo canônico. Toda narrativa possui seus actantes. 
O conceito de actante substitui com vantagem, mormente na semiótica literária, o termo personagem, e também "dramatis personae" (V. Propp), visto que cobre não só seres humanos, mas também animais, objetos e conceitos. Além disso, o termo personagem é ambíguo pelo fato de corresponder, também, em parte, ao conceito de ator (em que se pode realizar um sincretismo de actantes) definido como a figura e/ou o lugar vazio onde se investem tanto as formas sintáticas como as formas semânticas. (Idem, p. 21).

O protagonista, pertencente ao nível discursivo, é reconhecido no nível narrativo como actante sujeito e busca, geralmente, a conjunção com o seu objeto de valor ( $\cap$ Ov). A essa busca chamamos programa narrativo (PN) de base. Esse PN de base é dividido em quatro momentos: manipulação, aquisição de competência, performance e sanção.

A manipulação se dá comumente no início do PN, onde um destinador convence o sujeito a ir atrás de seu objeto, ou seja, o actante destinador é o que faz o sujeito fazer, instigando nele o querer-fazer ou o dever-fazer. No entanto, para que o sujeito consiga efetivamente conjungir com seu objeto de valor, ele também precisa saber-fazer e poderfazer. Geralmente há um novo PN (do qual chamamos programa narrativo de uso), onde o sujeito descobre algo crucial para obter a sua vitória, ou consegue um objeto essencial para melhor lutar, entre outras possibilidades narrativas. À obtenção desses saber-fazer e poder-fazer chamamos aquisição de competência.

Ao momento de embate entre o sujeito e seu antissujeito dá-se o nome de performance. É através dela que o protagonista finalmente conjunge com o seu objeto de valor. À conclusão, há a fase de sanção, onde o destinador sanciona os feitos do sujeito, recompensando-o ou punindo-o. À toda essa jornada do sujeito, somando seu PN de base aos seus PN's de uso, chamamos percurso narrativo.

Já no nível discursivo, voltamos a atenção às projeções de pessoa, espaço e tempo, assim como ao revestimento temático e figurativo que um texto possui.

(...) se entende por percurso figurativo um encadeamento isotópico de figuras, correlativo a um tema dado. Esse encadeamento, fundamentado na associação das figuras - próprio de um universo cultural determinado -, é em parte livre e em parte obrigatório, na medida em que, lançada uma primeira figura, essa exige apenas algumas, com exclusão de outras. Dadas as múltiplas possibilidades de figurativizar um único e mesmo tema, 
este pode estar subjacente a diferentes percursos figurativos; isso permite explicar as variantes. Assim, o tema "sagrado" pode ser assumido por figuras diferentes, tais como a do "padre", do "sacristão" ou do "bedel": nesse caso, o desdobramento figurativo da sequência se encontrará afetado por elas; os modos de ação, os lugares e o tempo em que esta deverá realizar-se, de acordo sempre com a figura inicialmente escolhida, diferirão entre si nas mesmas proporções. (Idem, p. 213).

Feito breve panorama do conceito de percurso gerativo do sentido, já que o leitor pode ser um entusiasta dos jogos, mas não necessariamente semioticista, também lançaremos mão de outros conceitos desenvolvidos pela teoria em momentos pontuais deste trabalho.

Por abordarmos um texto ainda não tão comum ao universo da semiótica, decidimos percorrer uma jornada de contextualização até chegarmos realmente à análise da intertextualidade manifesta em The Witcher III: Wild Hunt.

Fazendo breve busca por pesquisas que abordassem os temas "videogame/jogo eletrônico", "RPG/role playing game" e "semiótica" no sistema de bibliotecas integradas à Universidade de São Paulo (Dedalus-USP), notamos que há abordagens do jogo eletrônico como objeto da teoria da comunicação ${ }^{2}$, como influenciador em questões psicomotoras de seus usuários ${ }^{3}$, como representativo histórico ${ }^{4}$ e como objeto epistêmico ${ }^{5}$. Quanto ao RPG, já foi estudado como uma ferramenta de suporte didático para o ensino da língua portuguesa em turmas de Ensino Fundamental $\mathrm{II}^{6}$, e de física para

\footnotetext{
${ }^{2}$ Corrêa, Francisco Tupy Gomes. Ponto de equilíbrio entre a nova teoria da comunicação, o vídeo game e o Minecraft. Tese encontrada em http://dedalus.usp.br/F/KA29BD74AH6169ADQ8844PI9AGH7UTFF5B6VJRFV5Q7I4G7P1U21419 ?func=full-set-set\&set_number=002111\&set_entry=000007\&format=999, acesso em 21/01/2020.

${ }^{3}$ Um exemplo encontrado é:

Silva, Erika Cristina Gouveia e. Efeitos do videogame interativo Nintendo® Wii Sports na função motora de membros superiores de indivíduos com síndrome pós poliomielite: ensaio clínico aleatorizado de aplicabilidade, segurança, aceitabilidade. Tese encontrada em http://dedalus.usp.br/F/KA29BD74AH6169ADQ8844PI9AGH7UTFF5B6VJRFV5Q7I4G7P1U20242 ?func=full-set-set\&set_number $=002111 \&$ set_entry $=000002 \&$ format $=999$, acesso em 21/01/2020.

${ }^{4}$ Bello, Robson Scarassati. $O$ videogame como representação histórica: narrativa, espaço e jogabilidade em Assassin's Creed (2007-2015). Dissertação encontrada em http://dedalus.usp.br/F/KA29BD74AH6169ADQ8844PI9AGH7UTFF5B6VJRFV5Q7I4G7P1U25166 ?func=full-set-set\&set_number=002128\&set_entry=000011\&format=999, acesso em 21/01/2020. ${ }^{5}$ Lima, Luiz Henrique Magnani Xavier de. Isto não é só um jogo: videogames e construção de sentidos. Tese encontrada em http://dedalus.usp.br/F/KA29BD74AH6169ADQ8844PI9AGH7UTFF5B6VJRFV5Q7I4G7P1U31663 ?func=full-set-set\&set_number=002186\&set_entry=000018\&format=999, acesso em 21/01/2020. ${ }^{6}$ Torres, Patrícia. Escolhas lexicais e caracterização de personagens: uma proposta de atividade didática com base na leitura e no Role Playing Game. Dissertação encontrada em http://dedalus.usp.br/F/KA29BD74AH6169ADQ8844PI9AGH7UTFF5B6VJRFV5Q7I4G7P1U38971 ?func=full-set-set\&set_number=002206\&set_entry=000006\&format=999, acesso em 21/01/2020.
} 
turmas de Ensino Médio ${ }^{7}$. Abordando o jogo eletrônico da perspectiva da semiótica e da ludologia, destaca-se a Dissertação Ensaio semiótico sobre a narratividade nos jogos digitais, de Renato Razzino Ernica (2014), que nos foi fundamental para o desenvolvimento desta pesquisa.

Como já mencionado acima, a abordagem do RPG e do jogo eletrônico nesta Dissertação se difere das outras dantes citadas, de modo que o principal intento é, demonstrativamente, analisar como que o recurso da intertextualidade enriquece narrativamente episódios de The Witcher III: Wild Hunt.

O jogo escolhido pertence ao gênero "RPG de ação", de modo que nos foi necessário mergulhar nas raízes do RPG e problematizá-lo em questão de se apresentar como um fenômeno diferente do que se espera de um jogo pelas definições ludológicas consultadas. No Capítulo 1, analisamos as origens do RPG, mais precisamente do famoso Dungeons \& Dragons, voltamos a atenção para a sua inserção no meio eletrônico e problematizamos questões semióticas relativas ao gênero. Dado este primeiro passo, no Capítulo 2 contextualizamos o principal objeto de estudo desta Dissertação, voltando a atenção para a manifestação passional do sujeito protagonista de The Witcher III: Wild Hunt, ancorados na Semiótica das paixões e conceitos trabalhados por Claude Zilberberg (2011). Ao atingirmos o Capítulo 3, temos a análise da relação intertextual entre três episódios do jogo escolhido e textos literários da Cultura Ocidental.

A proposta desta Dissertação é, primeiramente, demonstrar que essa relação intertextual existe, o que enriquece e aumenta o peso narrativo do jogo e, em segunda instância, convidar o leitor a considerar, cada vez mais, o valor acadêmico que um jogo de videogame tem.

Contextualizada a pesquisa, damos início a esta de maneira similar a uma partida de RPG de mesa:

"Você adentra a sua sala de leitura. Os raios do sol penetram o vitrô lateral da sala, iluminando parcialmente a sua confortável poltrona de couro preto, o abajur

\footnotetext{
${ }^{7}$ Nascimento Júnior, Francisco de Assis. Role-playing games nas aulas de física. Artigo encontrado em http://dedalus.usp.br/F/KA29BD74AH6169ADQ8844PI9AGH7UTFF5B6VJRFV5Q7I4G7P1U43143?func=full-set-set\&set_number=002206\&set_entry=000013\&format=999, acesso em 21/01/2020.
} 
vizinho dela e a samambaia que orna um belo vaso preso à parede. As cortinas mal balançam, já que o vento que adentra a janela é quase inexpressivo.

Você olha à sua frente. $O$ tapete está impecavelmente esticado e a sua estante de livros está belamente organizada. O desejo de ler aflora. Caminhando alguns passos para a sua escrivaninha, encontra um calhamaço de papel. Pela sua curiosidade, você leva as mãos até o livro e o aproxima de seu rosto. A capa intitula uma Dissertação de Mestrado sobre intertextualidade e jogos eletrônicos. Você abrirá o livro e mergulhará no conteúdo inesperado?" 


\section{Capítulo 1}

\section{O RPG sob a lente da semiótica francesa}

\section{1. “Jogar” RPG ou "atuar” RPG?}

A sigla RPG denota "role playing game”, o que indica que é um jogo voltado para a interpretação de papéis. Sua origem se deu no fim do século XX, quando um grupo de jogadores de jogos de tabuleiro de estratégia (conhecidos como wargames) modificou tanto as regras que acabou criando o próprio jogo. Gary Gygax, inspirado pela literatura de J. R. R. Tolkien e junto de Dave Anderson, criou uma narrativa voltada para esses jogos em que um grupo de heróis deveria se infiltrar em uma fortaleza, direcionando o foco da brincadeira para a história dos infiltradores. Com a mistura de elementos de fantasia épica, um cenário similar à era medieval e o enfoque do jogo voltado para um grupo de aventureiros singulares, em meados dos anos 1970 nasceu o aclamado Dungeons \& Dragons, que se propagou mundialmente (VEUGEN, 2004, p. 82) ${ }^{8}$.

Dungeons \& Dragons - D\&D para os iniciados - é um jogo armado em uma mesa, geralmente com meia dúzia de participantes. É vendido em lojas e tem regras específicas, como Banco Imobiliário ou Scrabble, mas é radicalmente diferente. D\&D é um roleplaying game, um jogo onde os participantes controlam personagens em um mundo que basicamente só existe em sua imaginação coletiva (EWALT, 2016, p. 12)

Dungeons \& Dragons se passa em um mundo de fantasia inventado por seus jogadores, mas inspirado por séculos de narrativas e literatura. Livros como $O$ senhor dos anéis, de J. R. R. Tolkien, ajudaram a moldar o tom: cavaleiros heroicos e velhos magos sábios combatendo as forças do mal. Uma sessão típica de D\&D seria composta por um grupo de aventureiros em busca de tesouros em um complexo de cavernas ou lutando contra monstros gosmentos à espreita nas trevas.

Mas D\&D não é um jogo de tabuleiro com um mapa impresso e jogadas aleatórias (jogue um dado, mova quatro quadrados para perto do tesouro, pegue um cartão: "Você se assustou com um duende! Volte dois quadrados"). Em vez disso, cada partida é concebida antecipadamente por um dos participantes e, então, explorada de forma ativa pelos jogadores. (Idem, p. 13-14).

\footnotetext{
${ }^{8}$ Disponível em: https://brasilescola.uol.com.br/curiosidades/rpg.htm. Acesso em 21/01/2020.
} 
O indivíduo que prepara a partida de forma antecipada geralmente é eleito pelo restante do grupo de participantes e é conhecido como dungeon master, ou mestre, que é responsável pela criação do enredo que os jogadores vivenciarão, incluindo nele todos os desafios.

A pessoa que faz toda a preparação é chamada de Mestre. É tarefa dele imaginar um cenário, algo como "Arqueólogos descobriram a tumba de um faraó no deserto e os jogadores são ladrões de túmulos que precisam entrar no local e roubar o tesouro escondido". Ele também precisa organizar os detalhes, como desenhar um mapa e decidir onde há armadilhas, qual a localização do tesouro e que tipo de monstros o guarda.

Esse ato de criação entrega aos jogadores um mundo desconhecido para explorar e mantém cada partida diferente da anterior. É como sentar para jogar Banco Imobiliário sem saber os nomes ou os valores das propriedades até cair nelas. (Idem, p. 14).

O mestre de $D \& D$ também é responsável pela interpretação de todos os NPC ${ }^{9}$ 's da trama, tendo que atuar por todo novo personagem que surja na história, exercendo também a função de assumir o papel de inimigos, como monstros e criaturas, que irão se levantar contra os aventureiros.

Já aos jogadores, cabe primeiramente ter a noção de em qual ambiente a história estará ancorada, para que possam pensar na criação de seus personagens.

Os jogadores são tanto espectadores quanto autores em D\&D; eles consomem a ficção do Mestre, mas reescrevem a história com suas ações. Como autores, são livres para tomar as próprias resoluções. Se um troll está tentando engolir você, é possível golpeá-lo com a espada, atirar uma flecha ou implorar por misericórdia - a decisão é sua. Você pode até cantar uma música para ele, recrutá-lo para a cientologia ou tirar um cochilo. Sua escolha pode ser idiota, mas ela é unicamente sua.

Diferentemente dos jogos de tabuleiro, que limitam o participante a uma pequena variedade de ações, ou dos videogames, que oferecem uma larga, porém finita gama de possibilidades, os role-playing games dão ao jogador o livre arbítrio. Contanto que as regras do universo ficcional não sejam quebradas (...), você pode fazer o que quiser. (Idem, p. 16).

\footnotetext{
${ }^{9}$ A sigla denota non-playable character. Um NPC é um personagem que interage com os personagens dos jogadores, mas que não está no controle deles.
} 
O livro de Dungeons \& Dragons dispõe de regras para distribuição de pontos em atributos e habilidades, de modo que, se um jogador quiser encarnar um cavaleiro destemido, por exemplo, seria mais aconselhável investir os seus pontos em força, enquanto se uma outra jogadora pretende atuar como uma feiticeira, os pontos devem ser distribuídos em inteligência e assim por diante.

Um jogador em uma partida de D\&D não empurra por um tabuleiro uma peça de plástico pré-moldada. Em vez disso, ele cria um Personagem ou $\mathrm{PC}^{10}$ [Sigla em inglês que popularizou o termo], uma personalidade única para ser habitada como um ator, imbuindo-a de motivação, desejos e ação. (Idem, p.18, grifos nossos).

Quando todos os jogadores estão com os seus personagens criados, dá-se início à história, narrada pelo mestre. Ao encarnarem seus personagens, os jogadores devem interagir com o ambiente criado pelo dungeon master, explorando os cenários, resolvendo problemas, enfrentando inimigos, etc.

Uma "partida" (ou sessão) de $D \& D$ se assemelha a um exercício de teatro de improviso, afinal, Ewalt se refere aos jogadores também como atores, como descreve na página dezoito de seu Dados e homens, no entanto, há um elemento de sorte que influencia todo o progresso da narrativa: os dados, ferramentas fundamentais para o jogo.

No início de uma nova partida, os jogadores lançam um punhado de dados para determinar os atributos básicos de seus $\mathrm{PJs}^{11}$, seguindo as orientações de um livro de regras. Alguns desses atributos definem o personagem fisicamente: quão forte, habilidoso ou destemido ele será. Outros medem os traços de personalidade - se são perspicazes ou esquecidos, obstinados ou desistentes. Cada contagem é anotada pelo jogador e mantida para uma futura referência.

Ao longo da sessão, o jogador irá continuamente se basear em tais atributos para medir seu sucesso em determinadas ações. Deseja levantar uma pedra pesada e jogá-la nos bárbaros que estão invadindo seu castelo? Isso exigirá um número alto de força. Quer mergulhar por baixo do portão de ferro antes que ele feche? Desculpe, mas sua destreza é muito baixa. (Idem, p. 19).

\footnotetext{
${ }^{10}$ A sigla denota Player character.

${ }^{11} \mathrm{O}$ tradutor opta por usar a sigla PJ, que indica Personagem do jogador.
} 
Vê-se que, ao criar um personagem, o jogador deve levar em consideração o número obtido no lançamento dos dados para seus traços físicos. Um valor baixo obtido para uma característica indica que seu personagem é desfavorável em relação a ela. Em $D \& D$, não é uma atitude lógica um personagem com um valor baixo obtido para "força", por exemplo, tentar remover uma grande rocha da entrada de uma caverna com as próprias mãos.

Lançar um dado ainda pode indicar que um jogador está tentando executar uma ação específica. Dependendo do valor da face do dado somado aos pontos que o personagem já possui, o mestre anunciará, por meio da sua própria narração, se o personagem do jogador conseguiu executar aquilo que desejava.

Apesar de a sigla mencionar um "jogo de interpretação de papéis", questiona-se se realmente RPG seria um jogo ou exercício teatral. Segundo Johan Huizinga,

o jogo é uma atividade ou ocupação voluntária, exercida dentro de certos e determinados limites de tempo e de espaço, segundo regras livremente consentidas, mas absolutamente obrigatórias, dotado de um fim em si mesmo, acompanhado de um sentimento de tensão e alegria e de uma consciência de ser diferente da "vida quotidiana" (HUIZINGA, 2014, p. 33).

Pela descrição dada pelo historiador holandês podemos considerar, em role playing game, a existência de tensão no momento em que um jogador arremessa um dado procurando atingir um certo valor numérico para exercer uma ação, ao mesmo tempo em que a alegria se dá quando o grupo de jogadores vence o desafio imposto pelo mestre.

O sociólogo Roger Caillois divide jogo em quatro categorias:

Agôn - Todo um grupo de jogos aparece como competição, isto é, como um combate em que a igualdade das oportunidades é artificialmente criada para que os adversários se enfrentem em condições ideais, suscetíveis de dar um valor preciso e incontestável ao triunfo do vencedor. Portanto, sempre se trata de uma rivalidade que se concentra em uma única qualidade (rapidez, resistência, força, memória, destreza, engenhosidade, etc.), que se exerce em limites definidos e sem nenhum auxílio externo, de tal modo que o vencedor apareça como o melhor em uma determinada categoria de proeza. (CAILLOIS, 2017, p. 49).

Alea - Em latim é o nome de jogo de dados. Utilizo-o aqui para designar todos os jogos baseados, exatamente ao contrário do agôn, em uma decisão que não depende do jogador, 
sobre a qual não poderia ter a mínima ascendência e que, consequentemente, trata de ganhar mais do destino do que do adversário. Melhor dizendo, o destino é o único artesão da vitória, e esta, quando existe rivalidade, significa exclusivamente que o vencedor foi mais beneficiado por ele do que vencido. Alguns exemplos puros oferecidos por esta categoria de jogos são os dados, a roleta, o cara ou coroa, o bacará, a loteria, etc. (Idem, p. 53).

Mimicry - Todo jogo supõe a aceitação temporária, se não de uma ilusão (ainda que esta última palavra signifique apenas entrar no jogo: in-lusio), pelo menos de um universo fechado, convencional e, sob certos aspectos, fictício. O jogo pode consistir não em exibir uma atividade ou em experimentar um destino em um meio imaginário, mas em tornar a si mesmo um personagem ilusório e em se conduzir de acordo com ele. Encontramo-nos então diante de uma série variada de manifestações que tem como característica comum apoiar-se no fato de o sujeito simular crer, fazer crer a si próprio ou fazer com que os outros creiam que é um outro diferente de si mesmo. Esquece, dissimula, despoja-se passageiramente de sua personalidade para fingir uma outra. $\mathrm{O}$ termo escolhido para designar tais manifestações foi mimicry, que nomeia em inglês o mimetismo, principalmente dos insetos, para ressaltar a natureza fundamental e elementar, quase orgânica, do impulso que as suscita. (Idem, p. 57).

Ilinx - Uma última categoria de jogos reúne aqueles que se baseiam na busca da vertigem e que consistem em uma tentativa de destruir por um instante a estabilidade da percepção e de infligir à consciência lúcida uma espécie de pânico voluptuoso. De todo modo, tratase de aceder a uma espécie de espasmo, de transe ou de aturdimento que destrói a realidade com uma soberana brusquidão. (Idem, p. 62).

A partir da descrição das classes do jogo elucidada por Caillois, podemos afirmar que o role playing game se adequa à terceira classe, Mimicry, já que está no cerne do jogo o ato de o participante "vestir a máscara" de seu personagem e atuá-lo durante toda a partida, agindo como se fosse alguém diferente, porém, com elementos da segunda classe, Alea, já que o arremesso dos dados e os resultados completamente aleatórios deste implicam em consequências para o prosseguir da partida.

Já o game designer e teórico dos game studies Jesper Juul nos apresenta outra definição de jogo:

Um jogo é um sistema formal baseado em regras, com um resultado variável e quantificável, onde diferentes resultados são atribuídos por diferentes valores, de modo que o jogador investe esforço para influenciar tais resultados, sentindo-se vinculado ao resultado, proporcionando consequências opcionais e negociáveis através desta atividade. (JUUL, 2003, tradução nossa). ${ }^{12}$

\footnotetext{
${ }^{12}$ Transcrição do texto original: A game is a rule-based formal system with a variable and quantifiable outcome, where different outcomes are assigned different values, the player exerts effort in order to influence the outcome, the player feels attached to the outcome, and the consequences of the activity are optional and negotiable.
} 
O dinamarquês ainda cria uma tabela para indicar exemplos de atividades que se encaixam na sua definição, considerando RPG de lápis e pape ${ }^{13}$ como um caso fronteiriço entre jogo e não-jogo.

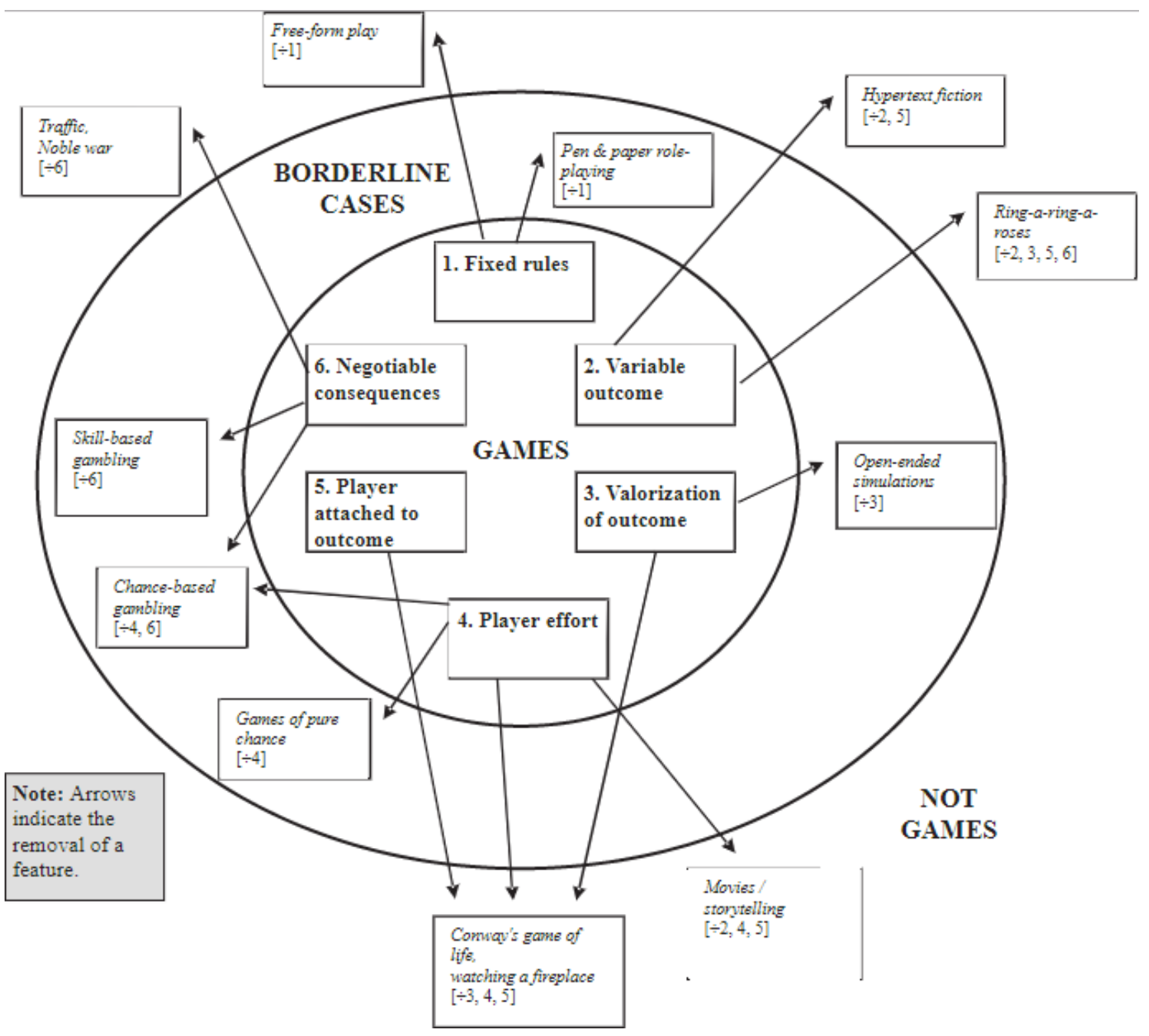

(Figura 1.1 - Tabela criada por Jesper Juul, indicando exemplos de JOGOS, CASOS FRONTEIRIÇOS (denominados por ele "quase-jogos") e NÃO JOGOS. Disponível em:

https://www.jesperjuul.net/text/gameplayerworld/6gamefeatures.svg, acesso em 21/01/ 2020)

\footnotetext{
${ }^{13}$ Aqui, o autor difere o RPG de lápis e papel, também conhecido como "RPG de mesa", com o qual estamos trabalhando neste item, do gênero "RPG" dentro dos jogos eletrônicos, o qual abordaremos no item 1.3 desta pesquisa.
} 
Segundo Juul, “jogos de interpretação com lápis e papel não são jogos normais porque, com um mestre humano, suas regras não são indiscutivelmente fixas" (Idem, tradução nossa $)^{14}$ o que não se coaduna com a primeira categoria fundamental de um jogo estipulada por ele.

Jogos têm regras. As regras dos jogos devem ser suficientemente bem definidas de modo que possam ser programadas em um computador, ou suficientemente bem definidas para que você não tenha que discutir sobre elas toda vez que for jogar. De fato, jogar um jogo não-eletrônico é uma atividade que, por si, envolve tentar retirar qualquer não-clareza das regras: Se há discordância em relação às regras do jogo, o mesmo é pausado até que a dúvida seja resolvida. (Ibidem, tradução nossa). ${ }^{15}$

Mais recentemente, o pesquisador Guilherme Xavier também propõe a sua definição própria de o que é um jogo:

(...) uma atividade notoriamente recreativa, normalmente envolvendo um ou mais participantes. Normalmente o jogo se apresenta com objetivos que precisam ser atingidos através de um conjunto de regras que permitem e proíbem ações e comportamentos. Ainda que os jogos apregoem uma finalidade de entretenimento, podem e são costumeiramente usados como exercício (para fins educativos, instrutivos e psicológicos). (XAVIER, 2010, p. 50-51).

Após sucinta apresentação da definição de jogo apresentada por diversos autores, notamos que tratar do role playing game é um desafio. A pergunta que norteia este item ainda se mantém, afinal, há, inclusive, modalidades de RPG em que os jogadores realmente encarnam os seus personagens ${ }^{16}$, trajando-se especificamente para o jogo e dispondo de suas habilidades teatrais para fazer fluir a aventura, de modo que cria-se uma linha tênue entre o que é uma partida e o que é uma "peça" de improviso, criada

\footnotetext{
${ }^{14}$ Transcrição do texto original: Pen and paper Role-playing games are not normal games because with a human game master, their rules are not fixed beyond discussion.

${ }^{15}$ Transcrição do texto original: Games have rules. The rules of games have to be sufficiently well defined that they can either be programmed on a computer or sufficiently well defined that you do not have to argue about them every time you play. In fact, the playing of a non-electronic game is an activity that in itself involves trying to remove any unclearness in the game rules: If there is disagreement about the rules of the game, the game is stopped until the disagreement has been solved.

${ }^{16} \mathrm{https} / / /$ pt.wikipedia.org/wiki/Live_action_(RPG). Acesso em 21/01/2020.
} 
concomitante à narração do mestre. Apesar de lançada a problematização, a maneira "padrão" de se jogar RPG, especificamente $D \& D$, o qual estamos analisando desde o começo deste capítulo, é sentando-se à mesa, pegando os dados, caneta e papel e preparando-se para atuar quando for o momento de dar voz ao personagem.

Lançamos mão de quatro definições de jogo propostas por pesquisadores de diferentes épocas e propomos breve análise de como o RPG se adequa às quatro, considerando-o uma atividade lúdica híbrida que permeia os campos do jogo e da dramaturgia. É um jogo pertencente à classe Mimicry esboçada por Caillois, permeado por elementos aleatórios, como mencionamos acima, e ainda pode ser considerado um tipo de entretenimento com um fim, como define Xavier, no caso, educativo, contribuindo para o desenvolvimento de habilidades de interação social dos jogadores ${ }^{17}$.

Todavia, o RPG de lápis e papel não se adequa à definição dada pelo historiador holandês, já que não há necessidade de o mestre encarar as regras do jogo como “absolutamente obrigatórias" (HUIZINGA, 2014, p. 33). Dungeons \& Dragons, por exemplo, possui um conjunto de regras pré-definido conhecido pelos jogadores como "livro do mestre". É neste caderno que o criador das aventuras checa todas as regras para resolver conflitos que podem se desenrolar ao longo da história, porém, e é aí que Juul tem um ponto, ater-se completamente às regras do livro é uma ação opcional do mestre.

Para exemplificar, digamos que o criador da história está narrando uma aventura em que os jogadores encarnam um grupo de cavaleiros buscando um tesouro. O mestre já inicia a narração posicionando os jogadores dentro de um templo antigo cheio de armadilhas. Um dos personagens acaba ativando acidentalmente um mecanismo que desprende um tronco enorme de uma das paredes que desliza em sua direção. Pelas regras, o jogador deve arremessar um dado e somar o valor da face deste aos seus pontos de destreza, simulando uma acrobacia de evasão, e torcer para que o valor atinja o número mínimo para que seu personagem consiga a performance de desviar do tronco. A face do dado indica o número um, o que, pelas regras, representaria um fracasso.

O mestre precisa narrar o que ocorre por conta dessa falha. Um tronco enorme causa uma quantidade de pontos de dano consideravelmente alta já prevista no livro de regras, o que pode representar morte certa do personagem, porém, o jogo acabou de

\footnotetext{
${ }^{17} \mathrm{https}$ ://hypescience.com/os-surpreendentes-beneficios-de-jogar-rpg/. Acesso em 21/01/2020.
} 
começar e espera-se que a partida dure horas. A morte de um dos personagens causaria certo mal-estar para o jogador, que passou muito tempo pensando no desenvolvimento de sua figura dramática, calculando pontos e preparando fichas de papel, e para a partida em si, já que o mestre pode ter preparado batalhas desafiadoras para o decorrer do jogo que exigiriam um grupo completo de personagens para serem vencidas, de modo que o narrador pode simplesmente abrir mão das regras e descrever uma consequência diferente para a falha daquele personagem, sem sequer considerar o tronco machucá-lo. Deste modo, o mestre abre mão da consulta à regra específica, podendo "perdoar" a falha da personagem, restaurando a possibilidade integral do jogo, mas não se configurando como o “desmancha-prazeres" descrito por Huizinga (2014, p. 14).

Abordada a complexidade lúdica do role playing game, mais especificamente, de Dungeons \& Dragons, e considerando-o jogo dentro das perspectivas propostas pelos estudiosos citados acima, neste trabalho proporemos uma análise de trechos de uma partida de $D \& D$ de um ponto de vista da produção de sentido, ancorados pela semiótica francesa e lançando mão da linha de pensamento adotada por Renato Razzino Ernica (2014), considerando o RPG um jogo que se cria no e pelo discurso.

(...) propomos que o jogo enquanto do âmbito do fenômeno e enquanto objeto da semiótica é não um objeto físico ou sistema virtual em si, mas uma competência, uma disposição de sujeitos. É esse ato enunciativo - único, portanto - de atribuir a corpos diversos um valor, ou seja, uma sistematização dos elementos disponíveis no espaço que servirá de base a uma performance, a qual chamamos partida. (ERNICA, 2014, p. 29).

\subsection{RPG e semiótica}

Considerando o exercício lúdico do RPG sob a lente da semiótica francesa, encontramos um tipo de texto diferente do convencional. Tomaremos como exemplo uma partida de $D \& D$ jogada por um grupo de bloggers, gravada e disponibilizada para público na internet, através de um podcast. Para melhor representação, identificaremos o personagem antes da respectiva fala, mas também o nome do jogador que o interpreta. Manteremos a transcrição de acordo com as falas, sem efetuar correções. No início da história tem-se o seguinte: 
Mestre (interpretado por Alexandre): - Vocês gastaram uma parte do dinheiro que vocês conseguiram na última aventura pedindo um belo cordeiro que está sobre a mesa.

Ruprest (interpretado por Deive): - Ah! Mas eu vou resolver isso já! Tem alguém com uma aparência que tem dinheiro perto?

Mestre: - Não. Vocês estão em uma taverna de médio porte. Ninguém tem... Ninguém com dinheiro vem pra uma taverna do povo!

Ruprest: - Mas alguém tá com cara de... com uma sacolinha de moedas de ouro dando bobeira?

Mestre: - Tem um cara no bar que tem uma sacola no cinto de corda.

Feldon (interpretado por Fernando): - Tá muito calor?

Mestre: - Foi calor durante o dia, agora o tempo refrescou um pouco.

Feldon: - Eu fiz uma magia de druida aqui de "criar água", porque eu tô com calor.

Nilberto (interpretado por Miguel): - Ah! Começou a chover dentro da taverna!

(risadas do grupo) ${ }^{18}$

Sabemos que a enunciação é um ato de linguagem em que um sujeito dotado de competência linguística produz um enunciado, instaurando-se em uma projeção de ego hic et nunc (GREIMAS, COURTÉS, 2016, p. 166-168). José Luiz Fiorin ainda nos complementa:

Como a pessoa enuncia num dado espaço e num dado tempo, todo espaço e todo tempo organizam-se em torno do "sujeito", tomando como ponto de referência. Assim, espaço e tempo estão na dependência do $e u$, que neles se enuncia. O aqui é o espaço do $e u$ e o presente é o tempo em que coincidem o momento do evento descrito e o ato de enunciação que o descreve. A partir desses dois elementos, organizam-se todas as relações espaciais e temporais. (FIORIN, 2016, p. 36).

A partir do exemplo do qual lançamos mão, consideramos o mestre de $D \& D$ como o enunciador e os jogadores que interagem com ele, enunciatários. No momento em que Alexandre assume seu papel de mestre do jogo e inicia a narrativa, também se configura como narrador, e as personagens encarnadas pelos seus amigos, narratários. No entanto,

\footnotetext{
${ }^{18} \mathrm{https}$ ://jovemnerd.com.br/nerdcast/nerdcast-251-especial-rpg-o-bruxo-a-princesa-e-o-dragao/ (0:08:05

- 0:08:38). Acesso em 21/01/2020.
} 
como os jogadores são responsáveis pelas ações de seus personagens, também assumem a instância actancial de sujeitos manipuladores, já que o jogador faz a personagem fazer.

Jogadores de D\&D controlam seus personagens usando uma combinação de narrativa em primeira pessoa e dramaturgia. Essa é a parte do jogo que confunde aqueles que nunca participaram de uma partida de D\&D. Na prática é bem simples.

Imagine que você é um personagem trancado em uma cela. O Mestre descreve o local baseado nas anotações dele: "Você está no canto de uma sala escura e fria, de mais ou menos 1 metro quadrado. As paredes, feitas de pedra, são interrompidas por uma pequena porta de madeira. Ela está fechada e a única fonte de luz do local é uma abertura, do tamanho de um punho, quase no teto."

Como um jogador, é preciso escolher uma ação e descrevê-la. Você poderia falar: "Eu tento forçar a abertura da porta."

Depois disso, o Mestre procura as regras de arrombamento de porta, consulta a planilha de personagens para medir sua força e joga um par de dados. Se você tiver sorte, ele dirá algo como: "Você usa toda sua força contra a porta e uma dobradiça se quebra. A porta cai com um estrondo no corredor.” (EWALT, 2016, p. 25, grifos nossos).

Apoiando-nos no Dicionário de semiótica (2016), podemos analisar melhor o jogador como manipulador de seu respectivo personagem.

Ao contrário da operação (enquanto ação do homem sobre as coisas), a manipulação caracteriza-se como uma ação do homem sobre outros homens, visando a fazê-los executar um programa dado: no primeiro caso, trata-se de um "fazer-ser", no segundo, de um "fazer-fazer"; essas duas formas de atividade, das quais uma se inscreve, em grande parte, na dimensão pragmática e a outra, na dimensão cognitiva, correspondem assim a estruturas modais de tipo factitivo. (GREIMAS, COURTÉS, 2016, p. 300-301).

Tradicionalmente, e numa primeira aproximação, a modalidade factitiva se define como um fazer-fazer, isto é, como uma estrutura modal constituída de dois enunciados em relação hipotáxica, que têm predicados idênticos, mas sujeitos diferentes ("fazer de forma que o outro faça...”).

Tal definição é notoriamente insuficiente. Se examinarmos apenas o enunciado modalizado ("o fazer do outro"), percebemos que não se trata de um enunciado simples, mas de um sintagma, denominado percurso narrativo do sujeito, que se decompõe em uma performance (o "fazer-ser" desse outro sujeito) e em uma competência (logicamente pressuposta por todo fazer, e que comporta uma carga modal autônoma). Quanto ao enunciado modalizador, seu fazer não visa a um outro fazer, pelo menos diretamente, mas ao estabelecimento do percurso narrativo do segundo sujeito e, em primeiro lugar, de sua competência; em suma, trata-se, para o sujeito modalizador, de "fazer qualquer coisa" de tal forma que o sujeito modalizado se institua, após esse "fazer", como um sujeito competente. $\mathrm{O}$ fazer do sujeito modalizador é igualmente, por conseguinte, um fazer-ser, isto é, uma performance - mas de natureza estritamente cognitiva - que coloca, inevitavelmente, o problema da competência cognitiva do próprio sujeito modalizador 
(competência consistirá primeiro no saber que incide nas virtualidades da competência do sujeito a ser modalizado). (Idem, p. 201).

Há no RPG um sincretismo actancial entre o jogador manipulador e seu respectivo personagem, já que é o jogador que controla todas as ações e as falas de seu personagem, ou seja, faz o personagem fazer exatamente toda e qualquer de suas performances na narrativa, de modo que a competência adquirida pelo personagem também dependerá da competência adquirida pelo próprio jogador manipulador no decorrer do jogo. Retomaremos a questão adiante.

Tomando o exemplo dos bloggers citado anteriormente, quando o mestre inicia a aventura in medias res, recapitulando o que o grupo havia feito antes do momento presente, abandona o tempo do pretérito e já assume o que Fiorin nomeou "presente pontual" (2016, p. 133): "Vocês estão em uma taverna de médio porte (...)". O mestre direciona o seu discurso a um $t u$ no momento em que o gatuno do grupo procura roubar alguém dentro da taverna, porém, essa pessoa não se refere ao jogador Deive, mas sim ao seu personagem, Ruprest. Dessa maneira, podemos afirmar que na narrativa criada pelo mestre há um simulacro surgido da fusão entre o interlocutor e a figura do narrador, ao mesmo tempo, entre os interlocutários (grupo de amigos) e os narratários (personagens fictícias da aventura).

Quanto à questão do tempo da enunciação, ainda apoiamo-nos em Fiorin:

Haveria, então, duas temporalizações: uma do enunciado e outra da enunciação. Esta é a temporalidade em que o narrador conta os eventos; a primeira, aquela em que os acontecimentos ocorreram. Cabe ainda lembrar que o que importa na determinação da temporalização é o tempo linguístico e não o tempo crônico. (FIORIN, 2016, p. 211).

É interessante analisar a sessão de Dungeons and Dragons por essa lente porque os acontecimentos estão na instância do agora, assim como a temporalização da enunciação, criando um forte simulacro, dando-nos a impressão de que o tempo linguístico e o tempo crônico se igualam. Isto pode ser melhor compreendido com mais uma transcrição da aventura de $D \& D$ dos bloggers citados acima: 
Mestre (interpretado por Alexandre): - Você tá numa trilha, já de terra, dentro de uma floresta, cercado por árvores. Você vê uma espada no chão, depois você vê um escudo manchado de sangue, depois você vê uma braçadeira de armadura com um braço dentro.

Artmos (interpretado por Eduardo): - Com um braço dentro?! Qual é o tipo de... é o quê?

Ruprest (interpretado por Deive): - De braço? (risadas)

Mestre: - É um braço humano.

Artmos: É rasgado, mordido, cortado?

Mestre: Cortado. À lâmina. Provavelmente numa porrada só. ${ }^{19}$

Por mais que a personagem de Eduardo, no enunciado produzido por Alexandre, esteja presente na cena de batalha, o jogador Eduardo não tem noção do que há pela frente, de modo que ele precisa aguardar a descrição do mestre para saber o que examinar e como agir. Como o tempo do enunciado está ancorado no agora, a narrativa só pode prosseguir com a narração do mestre, de modo que a dúvida do jogador em relação ao tipo de dano que causou a remoção do braço equivale à maneira como o seu personagem está examinando o ambiente, porém, tanto a resposta de Eduardo (interlocutário e, ao mesmo tempo, jogador manipulador buscando adquirir um saber para compor sua estratégia dentro do jogo), quanto a ação do personagem que ele encara (Artmos, manipulado por Eduardo e também buscando um saber dentro da cena do jogo), aguardam a descrição do cenário e de seus detalhes a partir da narração do mestre. Provavelmente, se Eduardo não estivesse interessado em saber a maneira como o braço encontrado havia sido decepado, Alexandre não daria a menor importância para descrever tal detalhe e isto nem seria mencionado em sua narração.

Há, portanto, um simulacro durante partidas de RPG que é extremamente comum em qualquer atividade lúdica como uma brincadeira de crianças ou uma competição esportiva, como demonstra Ernica:

Um dos eventos esportivos de maior popularidade no Brasil nos últimos anos tem sido o UFC (Ultimate Fighting Championship), em que diversos lutadores se desafiam no ringue octogonal pelo título, representado por um cinturão. O ringue, situado numa arena em Las Vegas é, de fato, um local aonde se pode ir (...). Os lutadores são fotografados, filmados, entrevistados e, portanto, existem, mas a pergunta que lançamos aqui é: o lutador

\footnotetext{
${ }^{19} \mathrm{https}$ ://jovemnerd.com.br/nerdcast/nerdcast-251-especial-rpg-o-bruxo-a-princesa-e-o-dragao/ (0:28:250:28:48). Acesso em 21/01/2020.
} 
conhecido como Minotauro é totalmente correspondente a Antônio Rodrigo Nogueira, a pessoa de fora do ringue? (...) Mais: devemos considerar esses lutadores como pessoas violentas? Dana White, o "chefão" do UFC, garante que não, que o comportamento dentro do ringue não se reflete fora dele. O Minotauro, portanto, existe dentro do evento (...). Trata-se de uma persona (máscara, em latim) e não de uma pessoa empiricamente localizada no mundo. (ERNICA, 2014, p. 34-35).

O que ocorre é que tanto Eduardo quanto os outros jogadores encarnam uma persona, cujo desenvolvimento, evolução e ações estão vinculados diretamente à narração de outra persona, o mestre (enunciador-narrador), que só existem dentro deste evento que é a partida de RPG. Entretanto, quando Antônio Rodrigo Nogueira encarna o Minotauro, por conseguinte, sabe as delimitações físicas do cenário em que sua "personagem" poderá percorrer, ao mesmo tempo que vê seu oponente e consegue reagir imediatamente em contrapartida às investidas deste, o que é diferente no RPG, já que todo o ambiente, inimigos, ações do inimigo, do clima, dos resultados provenientes dos arremessos dos dados, faz parte da construção discursiva elaborada por um enunciador.

Se o narrador de UFC espirra em sua cabine e, por alguns segundos, fica sem assistir à luta que está narrando, pode perder detalhes importantes do confronto, como um soco que desnorteia um dos competidores, porém, por tratar-se de um entretenimento televisionado, a falta da narração dos eventos não culminaria em uma perda total de experiência sensível do expectador, o que não é o caso em RPG de mesa. Se o mestre, narrador, deixar de narrar um fator importante da cena, todo um detalhismo essencial para a continuidade narrativa do jogo pode se perder, o que torna o role playing game muito mais complexo.

Os pequenos trechos da partida de RPG de mesa analisados se adequam à debreagem enunciativa do enunciado:

Ocorre quando os acontecimentos são narrados nos tempos enunciativos, para criar um efeito de sentido de simultaneidade entre a narração e os eventos:

Romário recebe a bola no meio do campo, passa por um, passa por dois, está diante do goleiro, chuta e goooool (transmissão radiofônica de um jogo de futebol).

Nas transmissões ao vivo, a narração dos fatos no presente cria a ilusão de uma perfeita simultaneidade entre narração e narrado. (FIORIN, 2016, p. 213). 
O exemplo de Fiorin nos é útil para reforçar nossas comparações. A debreagem enunciativa do enunciado ocorre em transmissões de jogos de futebol, criando a ilusão de que a narração e o narrado são simultâneos. O RPG de mesa se assemelha, já que as ações das personagens são simultâneas à narração dos jogadores. É só através da fala do jogador que o mestre saberá o que o personagem está fazendo, ao mesmo tempo que é só por parte da narração do mestre que os jogadores ficam cientes das consequências das suas ações no jogo e do universo em que estão inseridos.

Quanto à análise da narrativa presente no exemplo dos bloggers utilizado, as personagens dos jogadores encontram-se em disjunção com um objeto de valor, a princesa sequestrada pelo bruxo, e devem rumar para o esconderijo do inimigo para resgatá-la. $\mathrm{O}$ dungeon master encarna um destinador que orienta os jogadores, que, por conseguinte, controlam e guiam suas respectivas personagens sobre quais direções tomar e como devem alcançar seus objetivos dentro da narrativa ficcional.

Para toda performance se supõe uma aquisição de competência, no entanto, jogando RPG, o acaso pode ser um auxiliar fundamental nas performances dos personagens. A maioria das ações de um personagem em $D \& D$ exige rolamento de dados. Através de um número estipulado pelo mestre, o jogador deve somar os pontos de habilidade com a face obtida do dado e checar se o valor final superou o desafio proposto. Para melhor compreensão, vejamos um exemplo:

O combate em D\&D é organizado como uma sequência de ações narrativas e muitos lançamentos de dados. Se um jogador decide atacar com a espada, ele pode anunciar o movimento, mas é o Mestre quem calculará se a investida será bem-sucedida. Na prática, isso leva a uma equação matemática, algo como: (força do lutador + perícia do lutador) agilidade do alvo + armadura usada pelo alvo) + um elemento aleatório determinado pelo dado $=\mathrm{o}$ ataque funciona ou não.

Toda criatura no jogo - controlada pelo jogador ou pelo Mestre - tem um número específico de "pontos de vida" representando sua saúde. Quando um lutador atinge o alvo, ele joga os dados para ver quanto dano causa. O Mestre subtrai esse número dos pontos de vida do monstro. Cada jogador que ataca o monstro repete o processo até a criatura zerar seus pontos de vida e morrer. (EWALT, 2016, p. 28).

Dessa maneira, como nos é descrito por David M. Ewalt, se o valor obtido pela face do dado, somado à força do personagem, ultrapassa o valor da armadura do oponente, 
há um ataque efetivo (performance do sujeito), contudo, se a mesma soma não ultrapassa aquele valor, o inimigo bloqueia ou desvia do ataque (falha na performance).

Procuramos discutir algumas questões narrativas e enunciativas do RPG, em específico, de $D \& D$, munidos da teoria semiótica, entretanto, reconhecemos que é uma problemática para se desenvolver e se aprofundar que não cabe em um breve item de um capítulo de mestrado, o qual, neste trabalho, tem a função de contextualizar o leitor para a análise da narrativa de um jogo eletrônico, cujo gênero surgiu a partir do RPG de lápis e papel.

\subsection{RPG e o avanço tecnológico}

Com a evolução dos computadores no final do século XX, empresas consideraram a adaptação do estilo de jogo do RPG para os monitores eletrônicos da época, de modo que jogadores puderam desfrutar de aventuras solo, no que ficou conhecido como adventure game.

Em um adventure game, o protagonista, herói ou heroína, encara um "problema" (encontrar tesouros, expor um assassino, descobrir a própria identidade, etc.). O protagonista deve resolver este problema encontrando e utilizando objetos e pistas e resolvendo desafios lógicos e charadas. (VEUGEN, 2004, p. 78, tradução nossa) ${ }^{20}$

Já notamos que a definição de Connie Veugen se aproxima de uma descrição que se assemelha à formalização do plano narrativo de um texto em programas e percursos narrativos proposta pela semiótica narratológica de Algirdas Julien Greimas. Nos adventure games, o jogador encarna então um sujeito que busca conjunção com um objeto de valor e que deve sempre adquirir competência para sua performance.

\footnotetext{
${ }^{20}$ In an adventure game the protagonist, hero or heroine, faces a 'problem' (finding treasure, exposing a murderer, finding one's identity, etcetera). The protagonist has to resolve this problem by finding and using objects and clues and by solving (logic) puzzles and riddles. (texto original). Na tradução optamos por manter o termo "adventure game" em inglês, por se tratar de um gênero de jogo específico, não necessariamente qualquer jogo envolvendo aventuras.
} 
Surge então a questão: os adventure games poderiam ser considerados uma primeira tentativa de tradução intersemiótica do RPG de lápis e papel para o meio eletrônico?

A tradução intersemiótica, também denominada tradução interartes, consiste na transposição de um sistema de signos para outro. Trata-se de um movimento e processo que paradoxalmente faz equivaler significados através de um sistema sígnico diferente. Ou seja, a tradução intersemiótica reconhece a especificidade das várias linguagens semióticas (pintura, literatura, teatro, fotografia, cinema, televisão) e ao mesmo tempo acolhe o intercâmbio entre as mesmas em um processo de transcodificação criativa. ${ }^{21}$

Nessa então nova maneira de jogar, o mestre era substituído pela própria programação do jogo, que ia descrevendo, como um narrador, os ambientes e as situações que envolviam o protagonista.

Em Colossal Cave Adventure (1976), um dos pioneiros dos adventure games, também notamos o direcionamento do enunciado à primeira pessoa, mais precisamente ao personagem do jogador, de modo que o jogo cria um efeito subjetivo. (ver Figura 1.2).

${ }^{21}$ Descrição retirada de http://www.cchla.ufpb.br/encult4/index.php/eixos-tematicos/traducaointersemiotica/, acesso em 21/01/2020. 
In Narrow Corridor scrawled the inscription, "Fee fie foe foo [sic].

$>5$

In Narrow Corridor

You are in a long, narrow corridor

stretching out of sight to the west. At

the eastern end is a hole through which

you can see a profusion of leaves.

$>\mathbf{n}$

You can't go that way.

$>w$

(Figura 1.2 - Colossal Cave Adventure (1976). As expressões ">s", ">n" e ">w" representam comandos que o jogador digitava para indicar ao "narrador-computador" em qual direção sua personagem se deslocava, respectivamente ">south", ">north" e ">west". Disponível em: https://www.google.com/search?q=colossal+cave+adventure\&source=lnms\&tbm=isch\&sa=X\&ved=0ah UKEwi7vIW7j9bbAhXIF5AKHTyGADYQ_AUICygC\&biw=1440\&bih=794\#imgrc=ecuHDm20Kvq4i M. Acesso em 21/01/2020.)

O papel da linguagem verbal é fundamental, seja em um RPG de mesa como Dungeons \& Dragons, seja em um adventure game, porque é somente através dela que se cria o jogo. Para um jogador propor que seu personagem golpeie um monstro, ele precisa anunciar isso ao mestre. Para um jogador se mover ou explorar algo num ambiente adventure game, ele precisa “dizer" através do teclado, claramente, o que ele tem intenção de fazer.

Fã de adventure games, o programador Warren Robinett criou o jogo Adventure (1979), para um console de videogame da Atari na época.

O limite da tela do VCS foi quebrado quando Warren Robinett, apaixonado por um adventure de texto que jogava na faculdade chamado ADVENT (que rodava em computadores de grande porte, do tipo mainframes), resolveu criar uma versão gráfica para o VCS e a batizou Adventure (1979). Esse jogo é importantíssimo, pois, ao mesmo tempo, quebra paradigmas que serviriam de base para toda uma geração de novos jogos.

O primeiro desafio de Robinett foi transformar um adventure de texto (sem nenhum gráfico), no qual o jogador tinha de tomar decisões com base em descrições verbais dos locais onde se encontrava, e interagia digitando frases no teclado como "vá para oeste" e 
"pegue a chave", em algo totalmente gráfico, visto que o VCS não possuía teclado e seu jogo deveria se limitar a apenas 4 kb de código. (LUZ, 2010, p. 37)

O progresso de Robinett foi transformar uma aventura que se dava predominantemente pela linguagem verbal em um produto que misturasse o verbal, visual e sonoro. O desafio também residiu no fato de que o jogador não tinha a possibilidade de indicar textualmente as suas decisões no ambiente do jogo, como em um adventure game tradicional, mas manipularia o avatar através de um controlador que era dotado somente de uma alavanca para comandar a locomoção do personagem e um botão para que o mesmo interagisse com os itens predispostos no cenário do jogo (ver Figuras 1.3 e 1.4).

(Figura 1.3 - Adventure (1979). O jogador comanda um quadrado (em frente ao portão do castelo) que deve explorar o cenário em busca de um cálice mágico. Disponível em: http://www.atarimania.com/gameatari-2600-vcs-adventure_s6723.html, acesso 21/01/2020) 


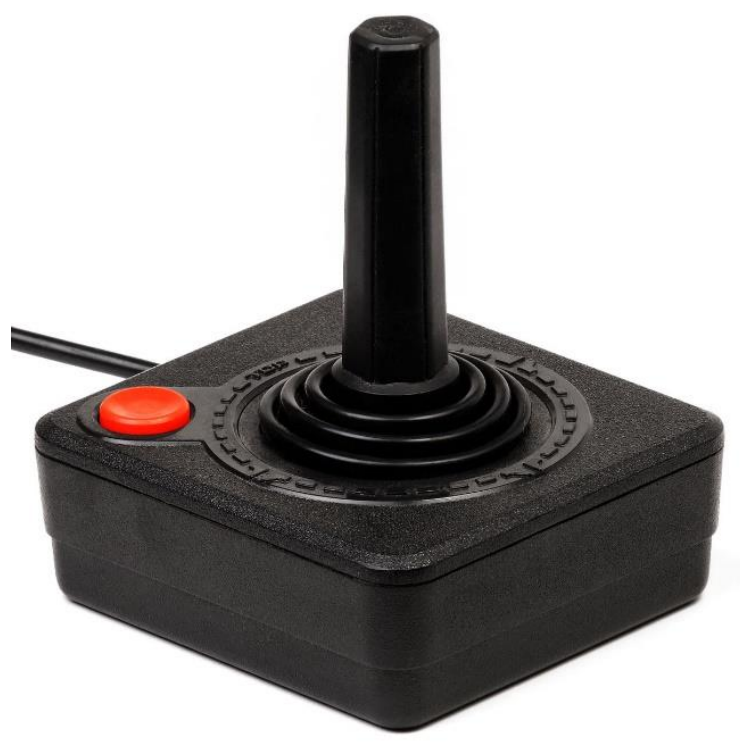

(Figura 1.4 - O clássico controlador do console Atari. Disponível em: https://en.wikipedia.org/wiki/Atari_CX40_joystick, acesso 21/01/2020)

O segundo desafio era solucionar graficamente o sistema de inventário que havia em ADVENT. Lá o jogador carregava coisas e as usava por meio de ações também digitadas. A solução encontrada por Robinett para esse problema foi permitir que seu avatar/cursor (um pequeno retângulo) carregasse apenas um objeto por vez, que ficava visível o tempo todo e era apanhado assim que o jogador encostasse-se no objeto. Ao encostar o cursor a um segundo objeto, o primeiro automaticamente era largado.

Essa solução trouxe uma profundidade estratégica fantástica, pois o jogador tinha de pensar muito bem em o que carregar em determinada parte do jogo, aumentando a tensão e o raciocínio a longo prazo. (Idem, p. 38).

Apesar de o jogador encarnar um "cavaleiro" destemido a explorar o mundo de Adventure em busca do cálice colorido, alguns dos elementos fundamentais do RPG não são encontrados no jogo, como a linguagem verbal expressa pela própria programação do jogo, fazendo o papel de narrador, da maneira que ocorre em Colossal Cave Adventure, ou o ato de o jogador dar voz ao personagem, o que resulta em uma perda considerável do elemento de subjetividade do jogo.

A questão de tradução intersemiótica deste tipo de jogo ainda pode ser analisada nas gerações mais recentes de videogames considerados do gênero RPG. Dragon Age Origins (Electronic Arts), um jogo de 2009, adapta razoavelmente bem a experiência original do RPG de mesa. O jogador assiste a uma introdução do que é o contexto em que 
o seu personagem irá se inserir no game e depois parte para a criação daquele, similar ao que fora descrito acima (ver Figura 1.5 e 1.6).

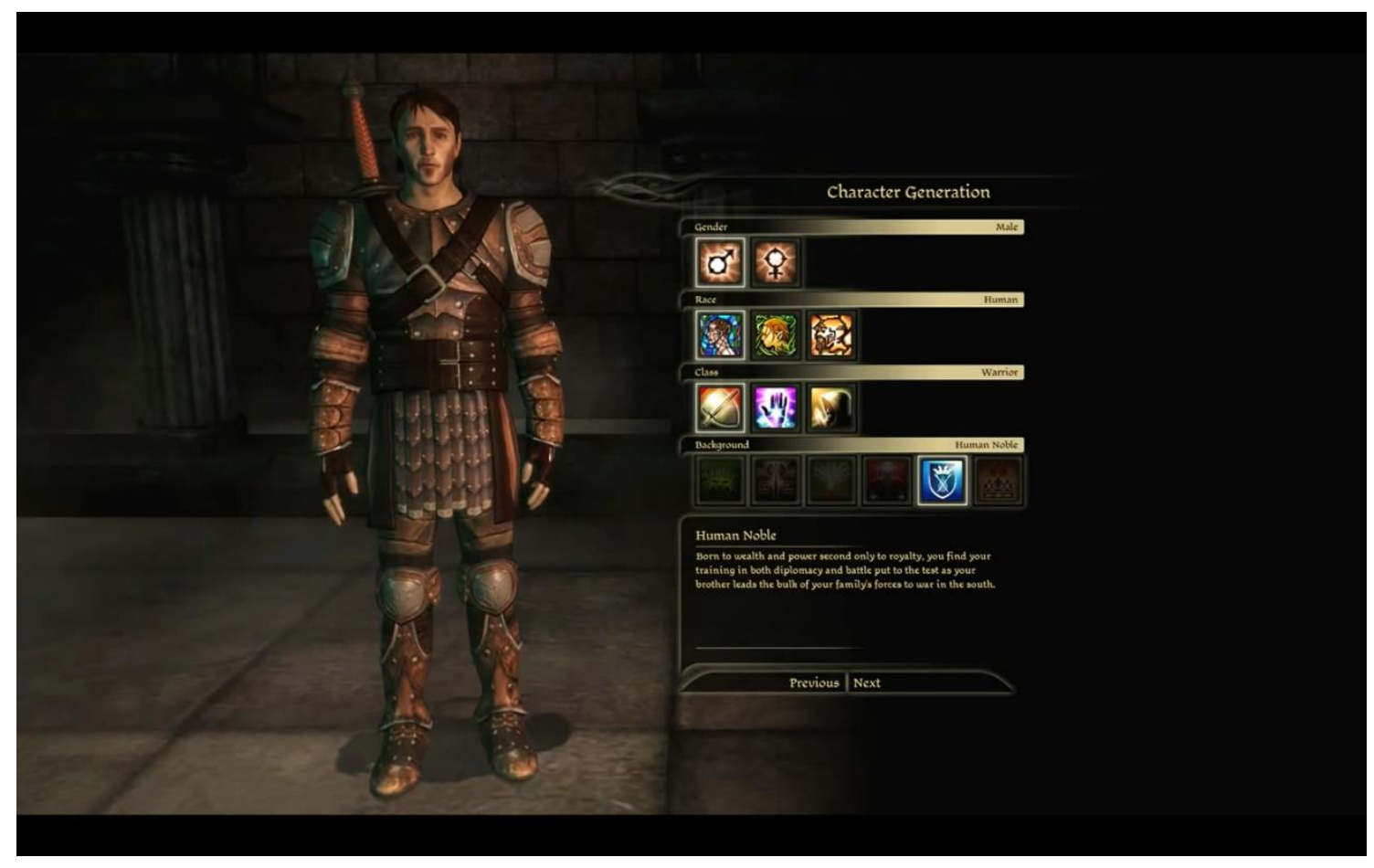

(Figura 1.5 - Criação de personagem em Dragon Age Origins)

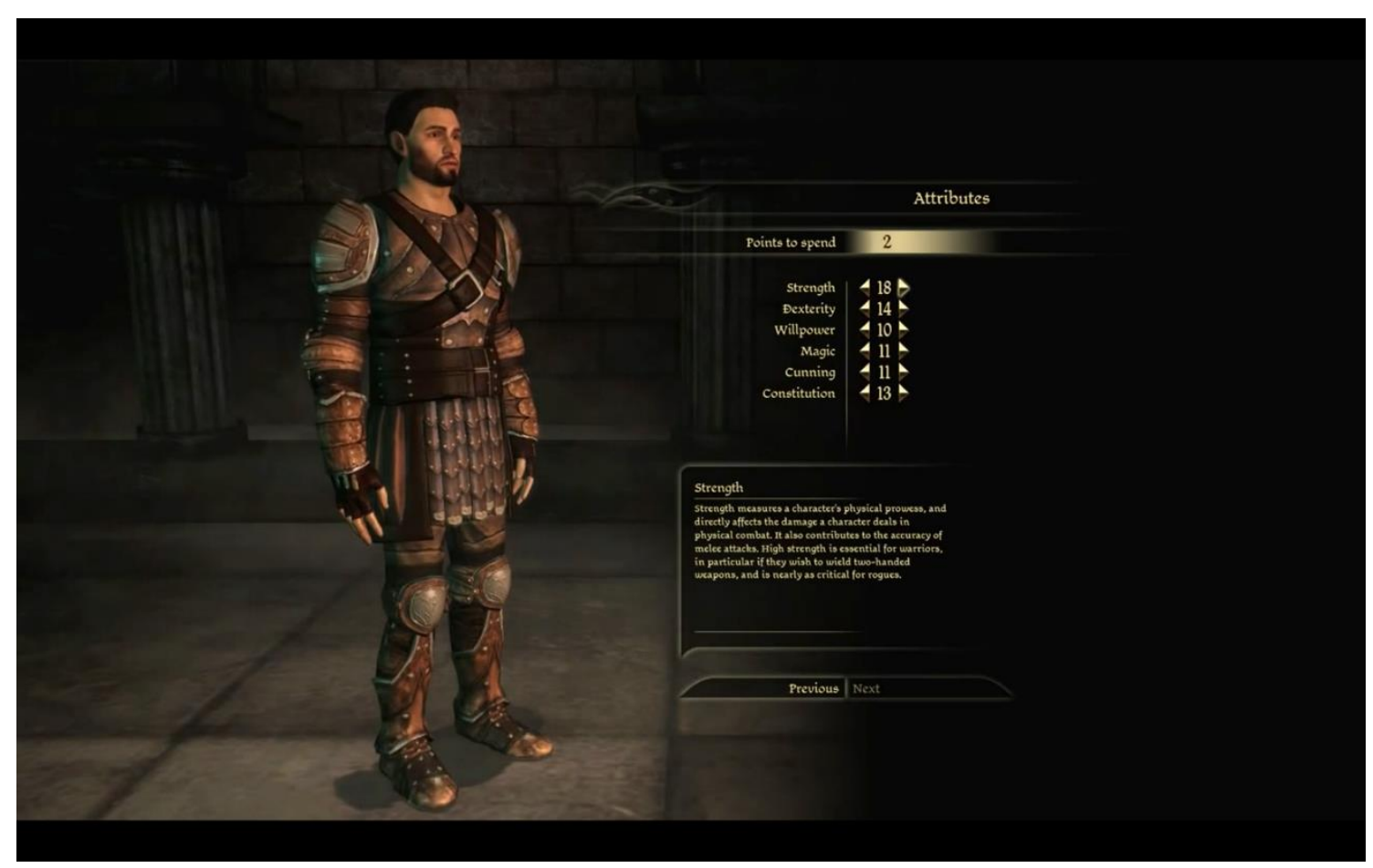

(Figura 1.6 - Distribuição de pontos de atributos) 
Primeiramente, o jogador seleciona o gênero e a espécie ${ }^{22}$ do personagem, podendo optar entre ser humano, elfo ou anão. Assim como em Dungeons \& Dragons, em Dragon Age Origins a "raça" do personagem influenciará em como o universo irá se relacionar com ele. O jogador também deve escolher a classe, optando entre guerreiro, mago ou gatuno, o que deve ser levado em consideração no momento de distribuir os pontos de atributo (conferir Figura 1.6). No caso do exemplo utilizado, o jogador preferiu colocar mais pontos em sua força, já que pretendia jogar com um guerreiro.

Dragon Age Origins também faz uso de debreagem enunciativa do enunciado, quando, após criado o personagem, o narrador do enredo o situa no jogo (ver Figura 1.7).

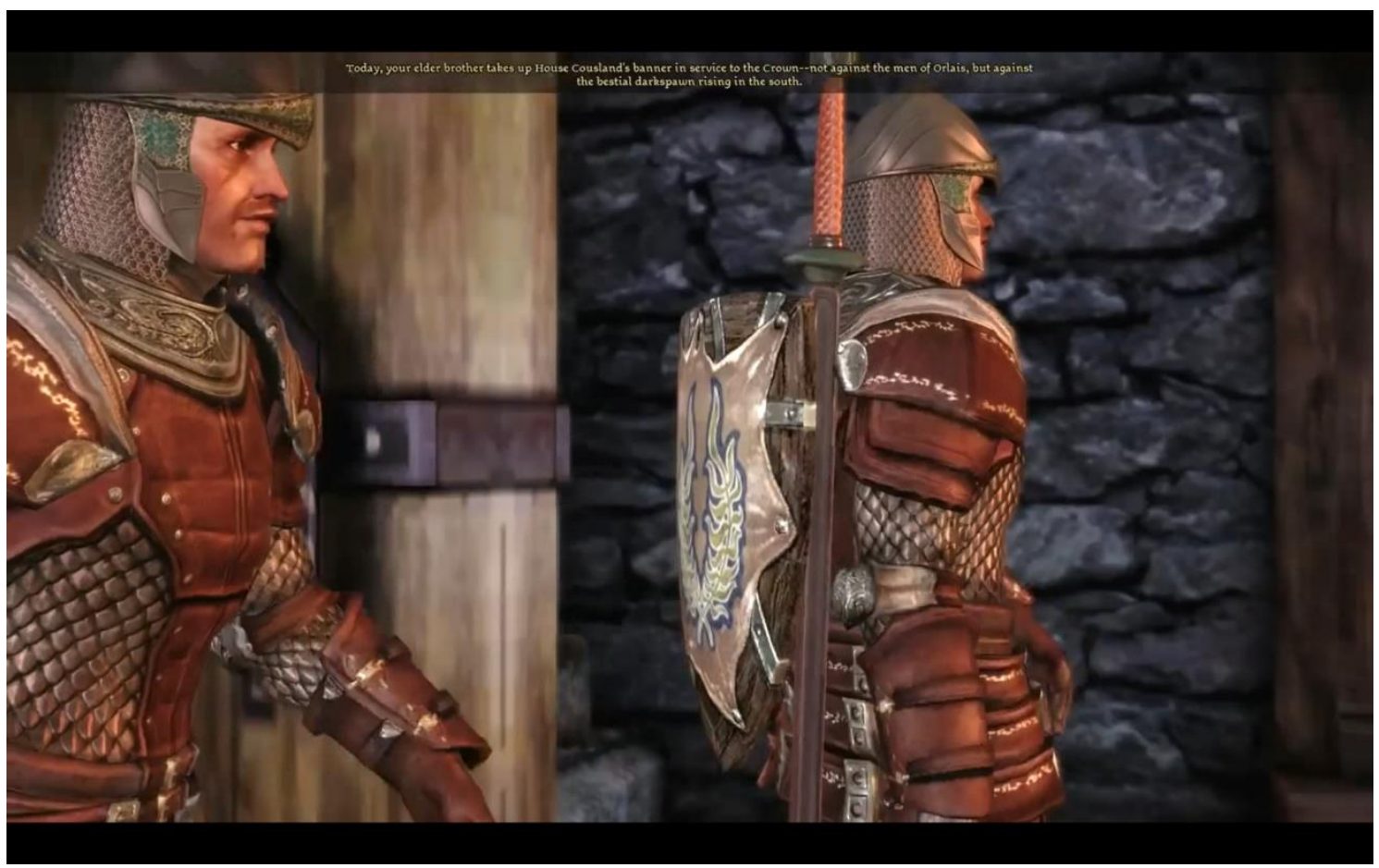

(Figura 1.7 - Legenda da cena diz: "Hoje, seu irmão mais velho assume o estandarte da Família Cousland em serviço à Coroa - não contra os homens de Orlais, mas contra os bestiais criassombrias ${ }^{23}$ que se erguem ao sul")

\footnotetext{
${ }^{22}$ Em jogos desse gênero, é muito comum o uso do termo "raça".

${ }^{23}$ Na versão em português do último jogo da série Dragon Age, o termo "criassombrias" é usado para traduzir a palavra darkspawn, usada para designar um grupo de criaturas malignas que emergem das cavernas comandadas por um dragão conhecido na mitologia do jogo como "Arquidemônio", o principal antagonista de Dragon Age: Origins.
} 
Neste momento, o jogador acabou de criar um humano nobre e está sendo contextualizado pelo narrador, antes da ação começar. Nota-se que, assim como o exemplo dos bloggers e de Colossal Cave Adventure, usados anteriormente, a narração se direciona à primeira pessoa, criando um efeito de aproximação do jogador enunciatário com o enunciado, prezando a subjetividade.

Como já demonstrado no caso de Adventure, de Robinett, com o avanço de produção de consoles de videogame que possuíam controles, nem todo jogo de gênero RPG teria a possibilidade de lançar mão de um teclado para que o jogador enunciasse diretamente as suas ações, como se faz em Colossal Cave Adventure. Em Dragon Age Origins, o próprio sistema é programado para fornecer uma quantidade de opções de diálogo e de ações quando o jogador vai "dar voz" ao seu personagem (ver Figuras 1.8 e 1.9).

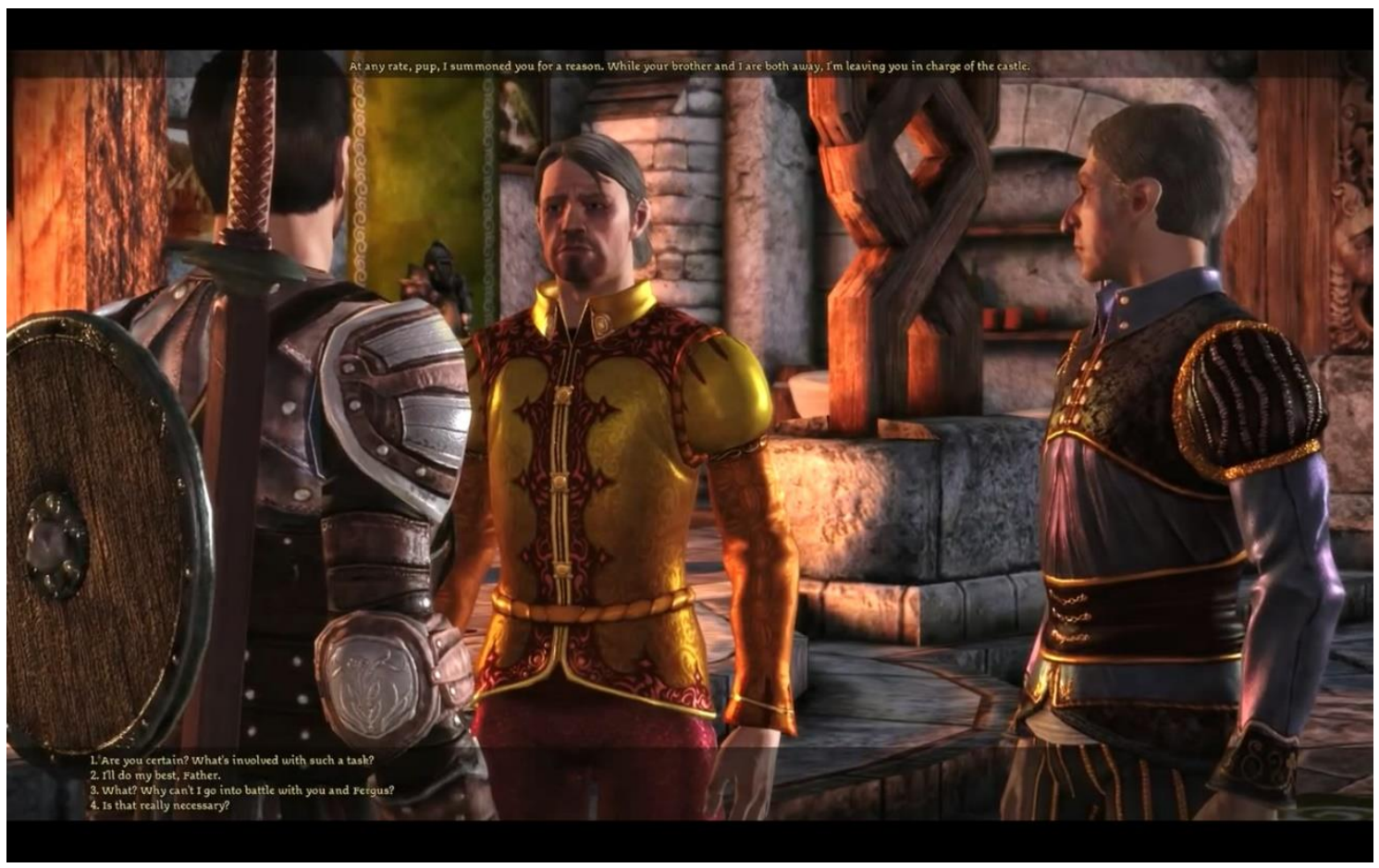

(Figura 1.8 - Após ser informado pelo pai que seu irmão mais velho marchará para batalha, o protagonista recebe quatro opções de escolha de frases para dar continuidade ao diálogo.) 


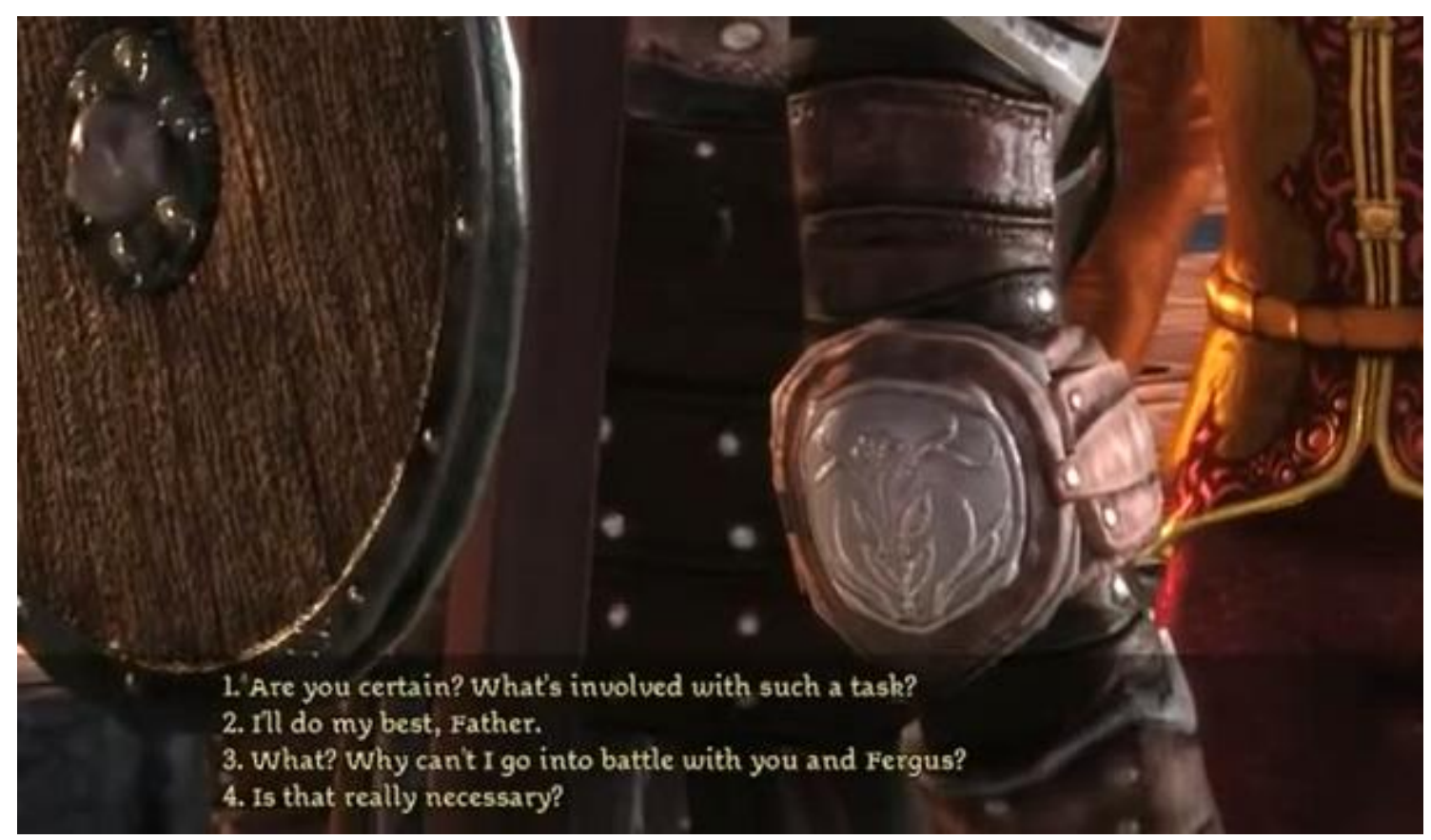

(Figura 1.9 - Zoom da Figura 1.8, focando na caixa de texto do jogo. O jogador pode optar por uma das seguintes falas para dar continuidade ao diálogo: 1. Você está certo? O que envolve uma tarefa como essa? / 2. Vou dar o meu melhor, Pai. / 3. O quê? Por que eu não posso marchar para a batalha com você e Fergus? / 4. Isso é mesmo necessário?)

Deste modo, Dragon Age Origins adapta de uma forma prática, porém não idêntica, a capacidade que o RPG dá ao jogador de assumir a voz de sua personagem. Consideramos que há limitações para se criar a mesma sensação de liberdade e subjetividade que o RPG de lápis e papel proporciona aos seus jogadores, já que é possível enumerar incontáveis decisões e opções de diálogo dentro de um jogo calcado pelo universo da imaginação ilimitada, o que não ocorre em um produto que trabalha com uma combinação finita de opções de falas programadas para serem escolhidas a fim de dar continuidade às conversas que surgem no ambiente eletrônico do videogame.

The Witcher III: Wild Hunt (CD Projekt), um jogo do gênero RPG de ação, e principal objeto de estudo desta pesquisa, lançado em 2015, adapta de forma ainda mais criativa a questão da escolha de falas na hora de o jogador dar voz ao protagonista. Em cenas de momentos de tensão, o sistema do jogo cria um temporizador. O jogador, então, precisa ler as suas opções e tomar uma decisão rápida, antes que o tempo acabe (ver Figura 1.10). 


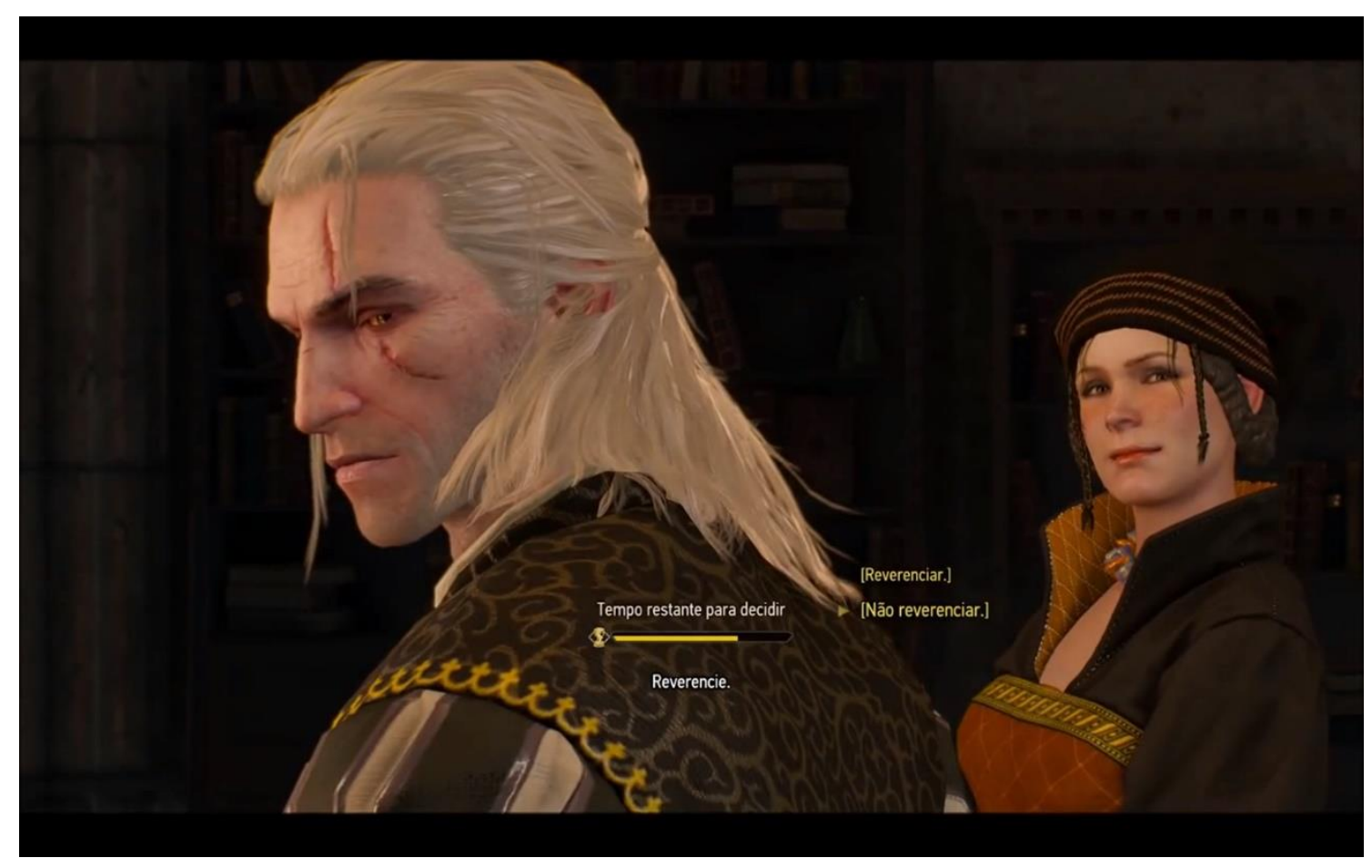

(Figura 1.10 - The Witcher III: Wild Hunt (CD Projekt))

$\mathrm{Na}$ figura acima temos uma cena em que o protagonista se apresenta diante da corte do imperador, um homem que ele odeia mortalmente. Ele já foi instruído por vários serviçais que é terminantemente proibido não reverenciar o poderoso. Quando a audiência imperial se inicia, o jogador recebe as opções "[Reverenciar.]" e "[Não reverenciar.]" e uma barra amarela indica "Tempo restante para decidir". Momentos como esse são feitos para gerar tensão no jogador e tentar simular ainda mais a questão da enunciação presente no RPG de mesa, em que o mestre pode optar por não esperar os jogadores pensarem demais em situações narrativas criadas para fazê-los agir assim que confrontados.

Tanto em Dragon Age Origins, como em The Witcher III: Wild Hunt, as escolhas de falas disponíveis ao jogador criam um escopo de reações e consequências já previstas no sistema do jogo, de modo que, por mais que adapte a questão da liberdade de assumir completamente a voz e as ações de seu personagem, como em um RPG de mesa, não consegue realmente criar a sensação de que boa parte do controle dos enunciados do personagem vêm do jogador, já que o sistema só lida com opções de diálogo que seriam previsíveis para o enredo, diferente do exemplo dos bloggers citado anteriormente em que, no meio da descrição da cena na taverna, Deive decide fazer com que seu 
personagem roube algum cliente, algo que talvez não estivesse previsto na história preparada pelo mestre.

Adaptar a lógica enunciativa por trás de um RPG de lápis e papel como Dungeons \& Dragons exige estratégias por parte dos desenvolvedores de jogos eletrônicos. Como analisado no item 1.2 desta pesquisa, é predominante a primeira pessoa $(e u / t u)$ e as instâncias do aqui e agora. Jogos eletrônicos usam do artifício da câmera para escolherem como querem narrar os seus enredos.

No momento em que o enunciador opta por projetar no texto um "eu" (que fala para um "tu"), um "agora" e um "aqui", são aproximadas as categorias dêiticas de pessoa, tempo e espaço entre enunciador/enunciatário, narrador/narratário e interlocutor/interlocutário. Os efeitos de sentido reforçados são a proximidade e a subjetividade. A segunda modalidade de projeção das categorias dêiticas utiliza as estratégias enuncivas ao configurar um "ele", um "então" e um "lá". Tais escolhas atuam de forma contrária às projeções enunciativas, promovendo um distanciamento e o efeito de sentido de objetividade. (ANGELO, 2015, p. 35-36)

Quando a câmera assume os olhos da personagem protagonista, temos uma perspectiva em primeira pessoa, por outro lado, quando aquela se fixa nas costas do avatar que o jogador controla, trata-se de uma perspectiva em terceira pessoa.

Segundo José Romero Cardozo Angelo:

Os jogos em primeira pessoa - referentes ao ponto de vista do player character representado visualmente - refletem um processo de debreagem enunciativa de pessoa. A estratégia é comum em jogos de tiro, mas dificilmente será empregada em jogos de interpretação de papéis, conhecidos como RPG - Role Playing Games (...) - é saliente a importância conferida à densidade sêmica de personagens - ou seja, ao alto grau de detalhe conferido pelo recobrimento figurativo - e à escolha de atributos físicos, de armas e de vestuário, bem como à visualização de toda a cena de confronto. (Idem, p. 36).

Para Angelo, jogos que utilizam do recurso de narrar a experiência através do posicionamento da câmera nas costas do personagem fazem uso da debreagem enunciva de pessoa, reforçando a objetividade e o distanciamento em relação ao enunciatário. Discordamos deste posicionamento. 
Tomemos como exemplo The Elder Scrolls V: Skyrim (Bethesda, 2011), um jogo de gênero RPG em que o jogador tem a opção de escolher em qual perspectiva prefere vivenciar a experiência (ver Figuras 1.11 e 1.12).

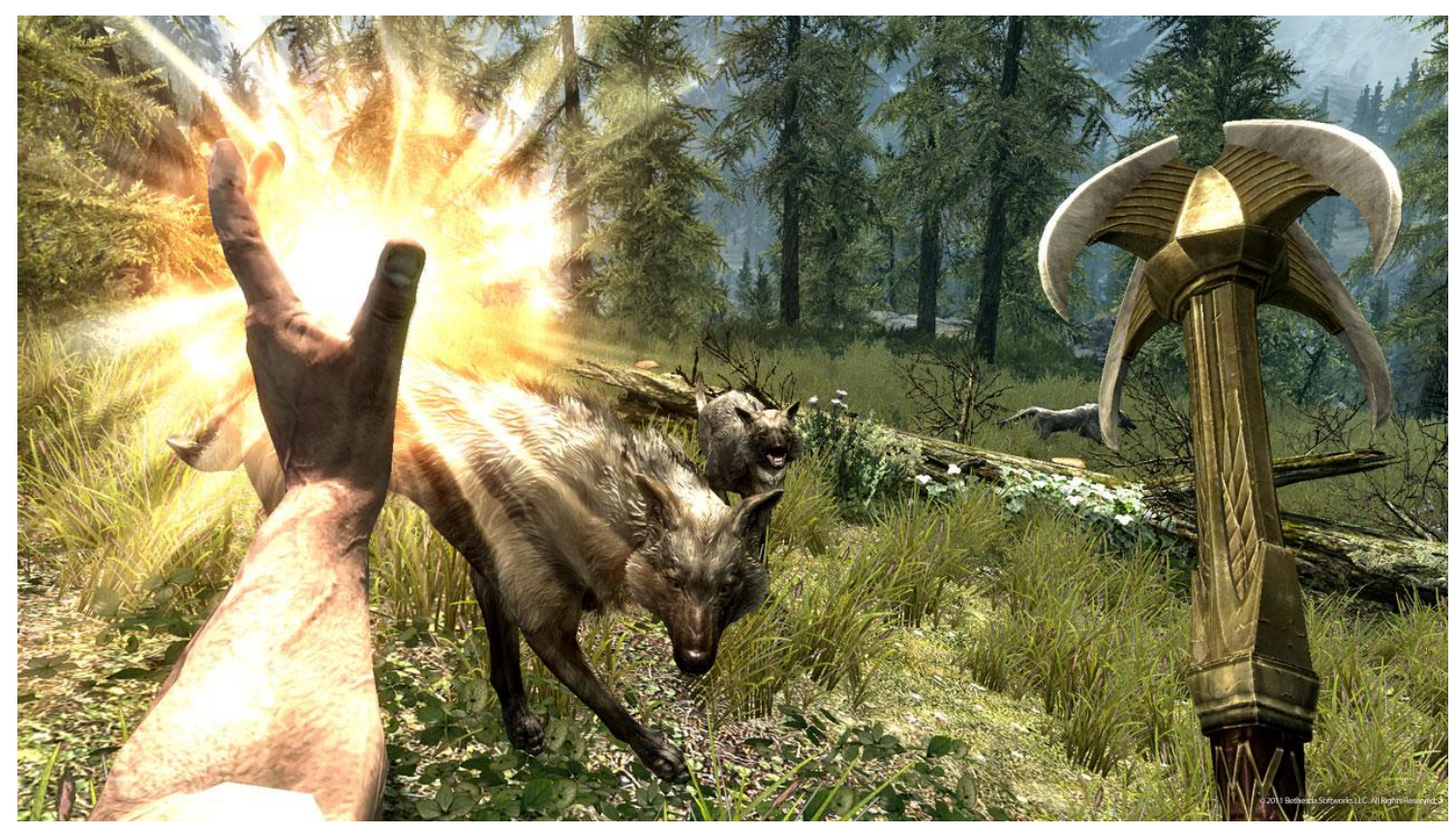

(Figura 1.11 - The Elder Scrolls V: Skyrim vivenciado em primeira pessoa. Disponível em: https://encyclopedia-la-gamia.fandom.com/wiki/The_Elder_Scrolls_V:_Skyrim, acesso em 21/01/2020) 


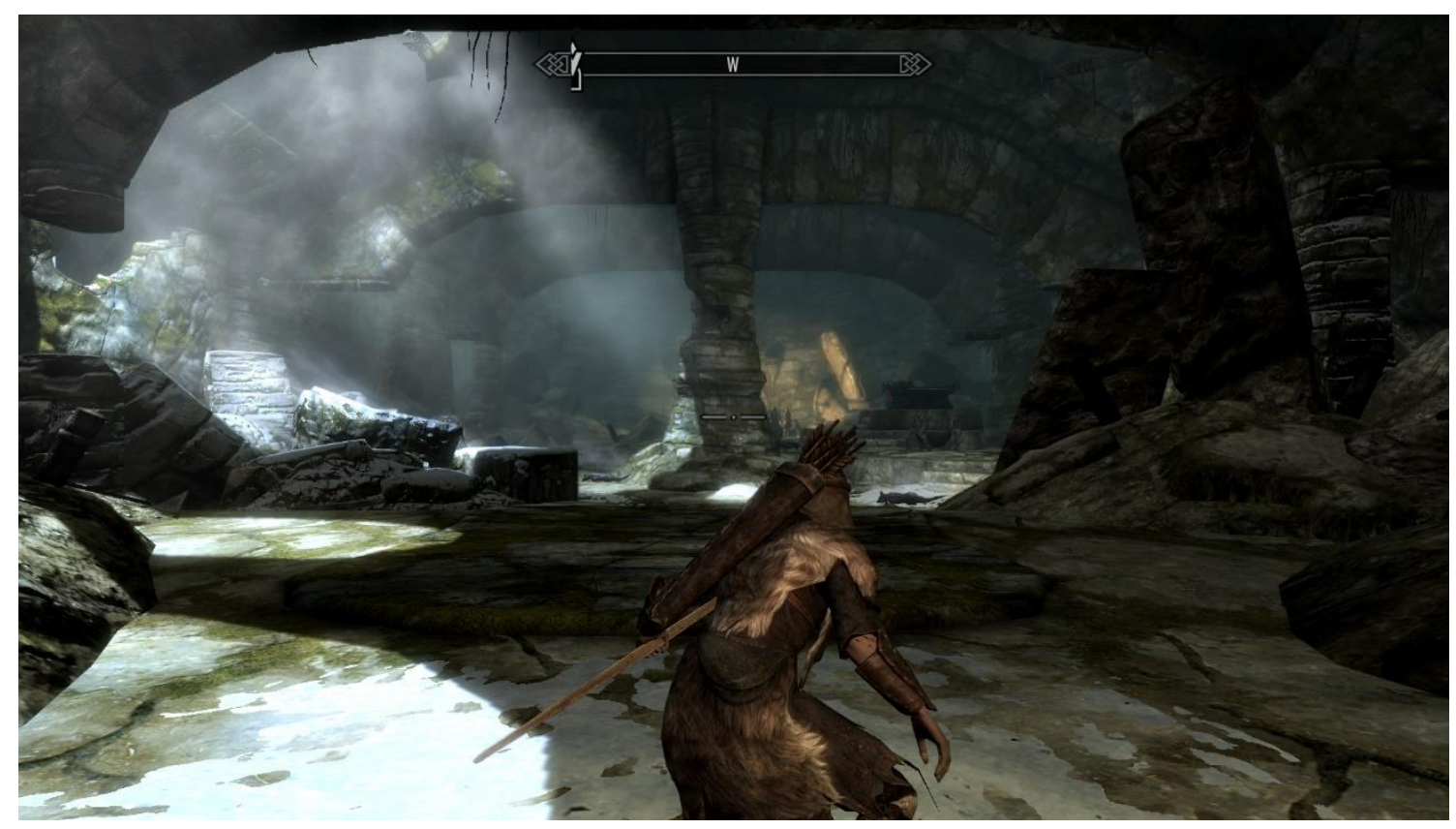

(Figura 1.12 - The Elder Scrolls V: Skyrim vivenciado em terceira pessoa. Disponível em: http://nerdsworthacademy.com/2011/11/15/skyrim-installed-and-then-it-was-monday/, acesso em 21/01/2020)

O efeito de subjetividade é maior em primeira pessoa, no entanto, ele não se perde em terceira pessoa, já que o jogador ainda dá voz ao personagem em momentos de diálogo. O plano da expressão da vivência em terceira pessoa exibe ao jogador um distanciamento fixo da imagem, de modo que não é possível ao controlador da ação dar um zoom out para analisar o cenário antes de tomar certas decisões, o que ainda mantém o efeito de proximidade. O que propomos é que há um simulacro de distanciamento que não se sustenta, já que ainda se tem o ponto de vista de um eu virtual, somente representado de um ângulo diferente, porém, responsivo às ações do controlador de forma idêntica à que se joga em primeira pessoa. Similarmente ocorre em outros jogos já citados, como The Witcher III: Wild Hunt, de maneira que consideramos que esses videogames mantêm astúcias enunciativas similares às de Dungeons \& Dragons.

Outra adaptação necessária dos RPGs de mesa para o meio eletrônico foi em relação ao arremesso de dados. Entrar em combate, escalar uma parede, mover-se silenciosamente são ações que sempre vão exigir o rolamento de dados em Dungeons \& Dragons e criarão um momento de tensão nos jogadores, já que a performance nunca é garantida. Em Runescape (Jagex), um MMORPG (Massive Multiplayer Online Role Playing Game), não se rola um dado virtual, mas o próprio sistema trabalha com geração de algoritmos aleatórios que simulam a mesma função. Quanto maior o nível em uma certa habilidade do personagem, maior é a chance de o algoritmo trabalhar a seu favor. 
Em uma experiência de combate, por exemplo, o jogador terá ciência de que, sendo seu personagem de nível 1, dificilmente conseguirá performar golpes efetivos contra um inimigo de nível 10, já que os valores de defesa deste serão muito mais altos.

Visualmente, a performance do personagem em combate se representa por símbolos. (ver Figura 1.13).

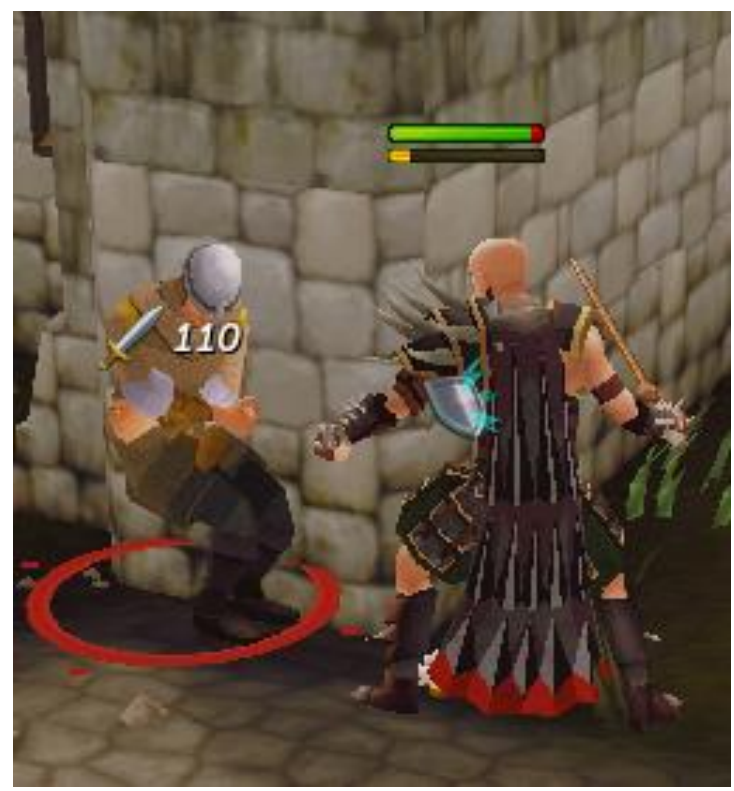

(Figura 1.13 - Combate em Runescape. Captura feita em 20/07/2018)

Na figura temos uma representação de combate padrão. Ao clicar em um inimigo, o sistema faz o papel do mestre de RPG de mesa, confrontando os valores de defesa do oponente com os valores de ataque do personagem do jogador. Caso haja performance, surge na tela a imagem de uma espada (caso o golpe seja físico), um arco (caso seja à distância), ou um chapéu de feiticeiro (caso seja de natureza mágica), e o valor numérico de dano causado ao opositor. Se houver falha na performance de combate, surge a imagem de um escudo, indicando que o alvejado não recebeu qualquer dano.

Como é muito comum no universo MMORPG, o jogador tende a querer confrontar inimigos de níveis mais altos, por proporcionarem um desafio maior e mais recompensas, mas nem sempre seu personagem tem o poder de executar tal performance. Investir em um confrontamento envolvendo um oponente de nível muito mais alto geralmente acarreta uma derrota. Jogos do gênero RPG de ação, como The Witcher III: 
Wild Hunt, comumente expõem um símbolo específico para alertar o jogador do poder de um oponente (ver Figura 1.14).

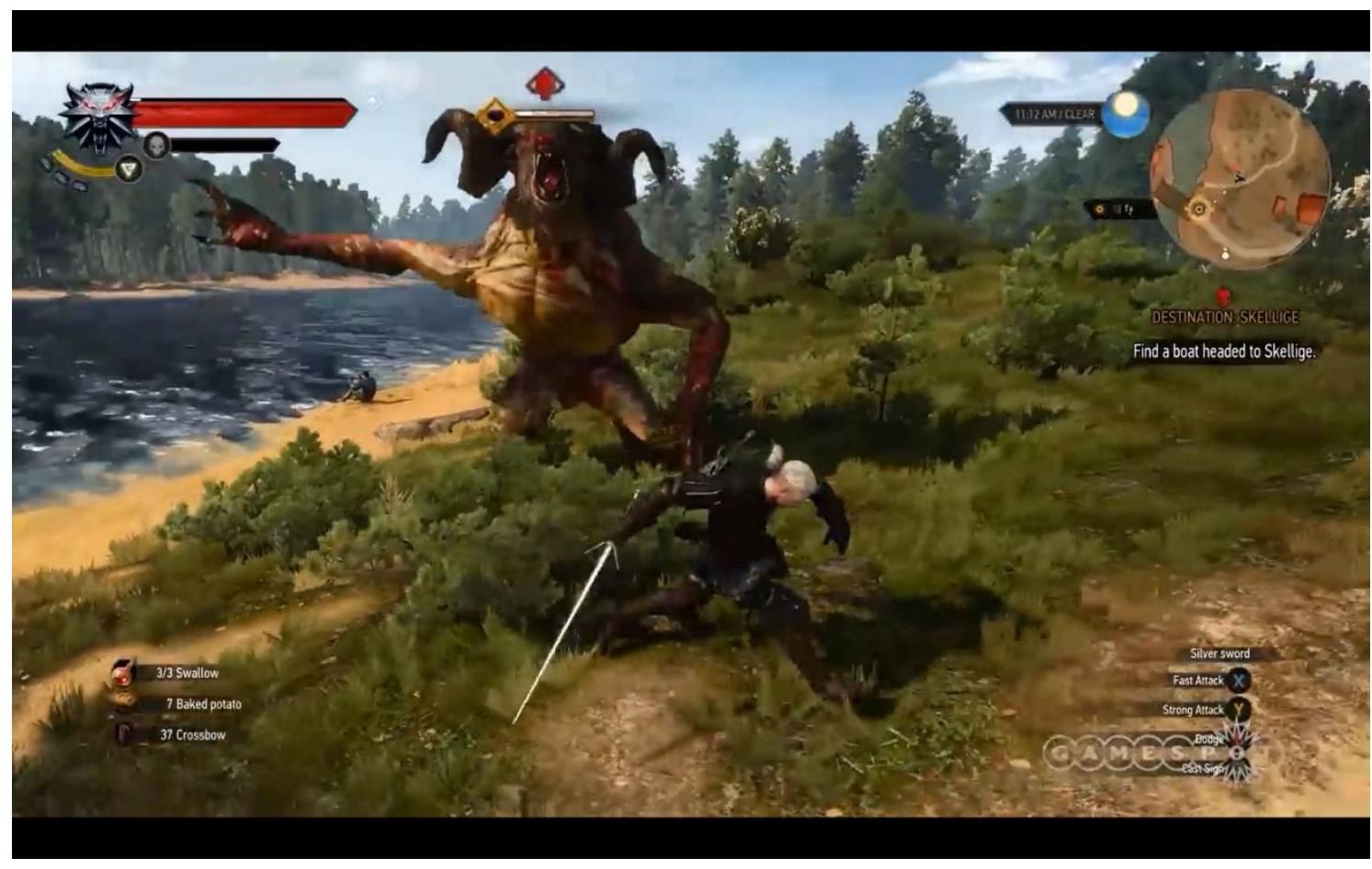

(Figura 1.14 - Protagonista enfrentando um inimigo considerado "invencível".)

Na imagem acima, o jogo representa os status do monstro com uma barra de vida sobre si. O crânio vermelho disposto superiormente indica ao jogador que é um oponente o qual o protagonista não tem o poder para enfrentar, o que vai exigir dele acumular mais experiência e evoluir alguns níveis para que o desafio seja de igual para igual.

Podemos dizer que falhas de performance em um RPG eletrônico dão a oportunidade ao jogador de testar novas estratégias após o game over, o que indicaria que o jogo é regido por uma lógica implicativa (se...então). Pelo exercício de tentativa e erro, quanto mais um jogador falha em um certo desafio, mais conhecimento dos padrões do jogo acumula para vencê-lo na experiência futura, no que Guilherme Xavier chama de "antibudismo", baseando-se em Steven Poole:

(...) o que temos é um processo de participação que aponta na direção oposta da penalização final, mas algo como um mecanismo de aprendizagem. O jogador que 
aprende a perceber os padrões do inimigo pode inclusive, sacrificar uma de suas "vidas" para alcançar um conhecimento que residiria no futuro. Quando confrontado com o desafio novamente, em sua segunda manifestação revivida, saberá exatamente como proceder, numa espécie de gambito ético de proporções restritas. Morra e se lembre, diríamos: onde se errou? Como se movimentar com mais segurança na próxima vez? (...) O budismo acredita na transcendência da alma (controle-mater) e sua reencarnação constante em etapas que em algum momento farão do indivíduo um ser iluminado cuja reencarnação seja desnecessária. A vida é uma etapa de sofrimento provador que em algum momento deixa de ser participada, pois, a evolução foi alcançada. Quanto menor o número de "reencarnações", melhor. No jogo, a ideia de morte colabora com um entendimento de aprendizado posterior que entre outros benefícios apresenta a possibilidade de se obter novas "vidas" para o estoque (mediante uma determinada pontuação). Vidas essas que serão ceifadas para que novas "vidas" e conhecimentos tácitos do jogo possam ser adquiridos. Portanto, quanto mais se "reencarna", melhor! Eis o antibudismo, nas minhas palavras, parafraseando Steven Poole (2001). (XAVIER, 2010, p. 216-217).

Em contrapartida, essa possibilidade de "reencarnação" não ocorre em Dungeons \& Dragons. Geralmente em RPG de lápis e papel, se um personagem morre, não há segunda chance ${ }^{24}$, de modo que o jogador perde aquela persona e, se quiser permanecer no jogo, deve criar um novo personagem do zero para a nova partida.

Apesar de apresentarmos breves exemplos de adaptações do RPG de mesa para o universo eletrônico, podemos dizer que os videogames deste gênero criaram o seu próprio caminho, já que é extremamente difícil se adequar ao meio eletrônico um tipo de jogo cuja a produção de sentido riquíssima está nas infinitas possibilidades narrativas produzidas pela imaginação dos jogadores.

Estamos longe de ter exaurido as fontes teóricas para apreciar nosso objeto, como também estamos distantes de ter abordado neste texto de pequena extensão todo um universo de análise que o role playing game pode proporcionar. Questões foram apresentadas e problematizadas, dando-nos breves considerações e, ao mesmo tempo, deixando um ponto de interrogação sobre o tema. Contudo, nosso objetivo neste capítulo foi contextualizar o RPG e a sua evolução, para que o leitor possa compreender em que ambiente está inserido The Witcher III: Wild Hunt, um jogo eletrônico disponibilizado para compra em 2015, de gênero RPG de ação, principal objeto de estudo desta pesquisa de mestrado.

\footnotetext{
${ }^{24}$ Estamos desconsiderando um enredo criado por um mestre em que seja possível ressuscitar uma personagem morta, no entanto, fugindo aos padrões, isto seria possível se considerado verossímil pelo contexto da narrativa.
} 


\section{Capítulo 2}

\section{Sobre o objeto de estudo}

\subsection{Escolha}

Iniciar uma pesquisa científica exige um objeto de estudo. The Witcher III: Wild Hunt foi a nossa opção por ser um jogo que causou uma grande revolução na indústria dos videogames, trazendo uma quantidade considerável de elogios à empresa desenvolvedora $^{25}$, CD Projekt Red, além de conquistar inúmeros prêmios, inclusive o de Jogo do Ano de 2015, pelo Video Game Awards ${ }^{26}$.

Estávamos experienciando um título $\mathrm{AAA}^{27}$ e buscando entender as razões para a alta quantidade de premiações e elogios. Mais precisamente, como adeptos da semiótica greimasiana, as intenções se voltaram para compreender a produção de sentido por trás do jogo eletrônico eleito o melhor de 2015, visando, principalmente, uma análise de sua narrativa.

Vale ressaltar que, apesar de o enfoque analítico ter se voltado desde o começo para o enredo, lidamos como um jogo de videogame, ou seja, um texto sincrético que, além de pertencer à esfera do verbal, também se faz visual e sonoro, além de interativo, já que, sem a intervenção de um jogador manuseando o controlador do console, não há progressão da narrativa.

Chamou-nos a atenção muitos dos recursos figurativos, mas acima de tudo, as relações intertextuais presentes na narrativa do jogo, que serão abordadas em capítulo específico.

\footnotetext{
${ }^{25}$ Segundo artigo publicado no site https://pt.wikipedia.org/wiki/The_Witcher_3:_Wild_Hunt\#Prêmios, do qual utilizou mais de 91 links de consulta sobre o jogo. Acesso em 21/01/2020.

26 http://g1.globo.com/tecnologia/games/noticia/2015/12/witcher-3-e-eleito-game-do-ano-e-melhor-rpgno-game-awards-2015.html. Acesso em 21/01/2020.

${ }^{27}$ Lê-se em inglês "triple A". A classificação AAA, no campo dos jogos eletrônicos, indica um produto que teve um grande investimento orçamentário para ser produzido, de modo que se espera ser um grande título, mais precisamente, o melhor em qualidade que uma empresa específica possa oferecer ao público.
} 


\subsubsection{O que é The Witcher III: Wild Hunt}

Ao correr dos anos 1990, o economista Andrzej Sapkowski publicava, na Polônia, a sua série de romances de fantasia que ficou conhecida como Wiedźmin, posteriormente traduzida para o inglês como The Witcher. Os romances foram tão bem aceitos pelo público e pela crítica que, em 2012, o autor recebeu a medalha de prata Gloria Artis do ministro da cultura de seu país.

Posteriormente, próximo a 2007, a desenvolvedora de jogos polonesa CD Projekt comprou os direitos de Sapkowski, produzindo o jogo The Witcher. A aventura eletrônica não seria uma adaptação da narrativa presente na série de romances, mas sim, a criação de um novo enredo que se sucederia após a conclusão dos livros, apresentando as peripécias e aventuras do protagonista Geralt de Rívia após sua perda de memória, dando origem à uma narrativa completamente original.

The Witcher foi lançado como jogo de computador para o sistema Windows e Mac, sendo a primeira tentativa da CD Projekt para se inserir no mercado. O jogo foi muito bem recebido pelo público e aclamado pela crítica.

Em 2011, a produtora lançou o segundo título da série, The Witcher II: Assassin of kings, que, dessa vez, além de poder ser jogado no computador, também foi desenvolvido para o console da Microsoft, o Xbox 360. Em meados de 2013, a série de jogos já havia alcançado a marca de oito milhões de cópias vendidas. Com o sucesso, em 2015 lançaram The Witcher III: Wild Hunt, jogo conclusivo da trilogia, agora também disponível para o console da Sony, Playstation $4{ }^{28}$

O enredo do jogo se volta para Geralt de Rívia, pertencente à casta dos bruxos, homens que passam por uma série de mutações genéticas para terem suas habilidades aprimoradas, tornando-os capazes de enfrentar monstruosidades que assolam as terras habitadas por humanos. Geralt embarca em uma jornada para encontrar Ciri, a qual adotou e treinou durante a infância, sabendo que ela corre perigo. A garota é possuidora de um poder inigualável, mencionado na história como o Sangue Ancestral, o que a permite viajar no tempo e espaço, visitando outras dimensões. Tal poder é cobiçado por Eredin, o

\footnotetext{
${ }^{28}$ https://pt.wikipedia.org/wiki/The_Witcher_(s\%C3\%A9rie_de_jogos_eletr\%C3\%B4nicos). Acesso em $21 / 01 / 2020$
} 
rei da Caçada Selvagem, um grupo de soldados fantasmagóricos que assolam a terra e dão origem às inúmeras lendas de maldições na boca dos camponeses amedrontados constantemente.

\subsection{Pela visão da semiótica}

Existe um embate contínuo entre /vida/ e /morte/ em The Witcher III: Wild Hunt. A própria profissão de Geralt o põe em risco de vida constante, já que defender a humanidade de monstros sempre o insere em conflitos bélicos. Dentro da narrativa presente no jogo, há toda uma gama de antissujeitos que visam a morte de Ciri, sendo o principal, Eredin, que para extrair o poder da garota, intenta em aniquilá-la. Não só isso, dentro da mitologia da série The Witcher há a crença de que a Geada Branca, um fenômeno apocalíptico em que o frio e a neve exterminarão toda a vida no mundo, só pode ser parada pela herdeira do Sangue Ancestral, o que também implica um risco de vida à garota.

Em questões práticas do jogo, Geralt é um protagonista que pode se machucar, de modo que a sua morte culmina na tela de "Game over". O jogador deve ter a habilidade de controlar o personagem de forma a sair vitorioso nos combates e não sofrer danos. No canto superior esquerdo da tela do jogo é exibida uma barra de vitalidade, que indica, cromaticamente através de um preenchimento em vermelho, o quanto de /vida/ há no avatar que o jogador controla.

Ao entrar em combate contra um monstro, ou um bandido, caso Geralt seja atingido, sofrerá uma perda gradual em sua barra de vitalidade, de modo que o vermelho dará lugar a espaços em preto. Caso a barra se esvazie completamente de vermelho, o personagem morre e o jogo se encerra, exibindo a informação "Você morreu". Para se recuperar, Geralt pode consumir comida que encontra ao longo do jogo, ou poções que ele mesmo tem a capacidade de fabricar. Deste modo, podemos representar a oposição /vida/ vs. /morte/ presente em The Witcher III: Wild Hunt: 


\section{Quadrado semiótico \\ Geralt em combate}

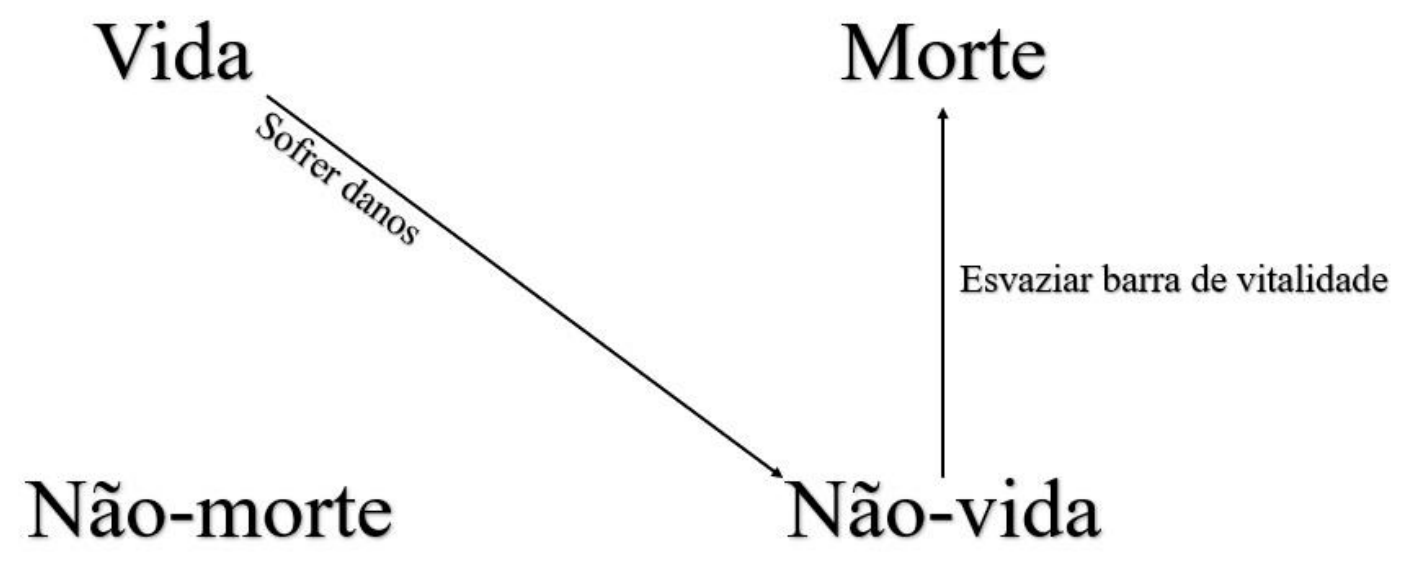

\section{Quadrado semiótico \\ Geralt em combate}

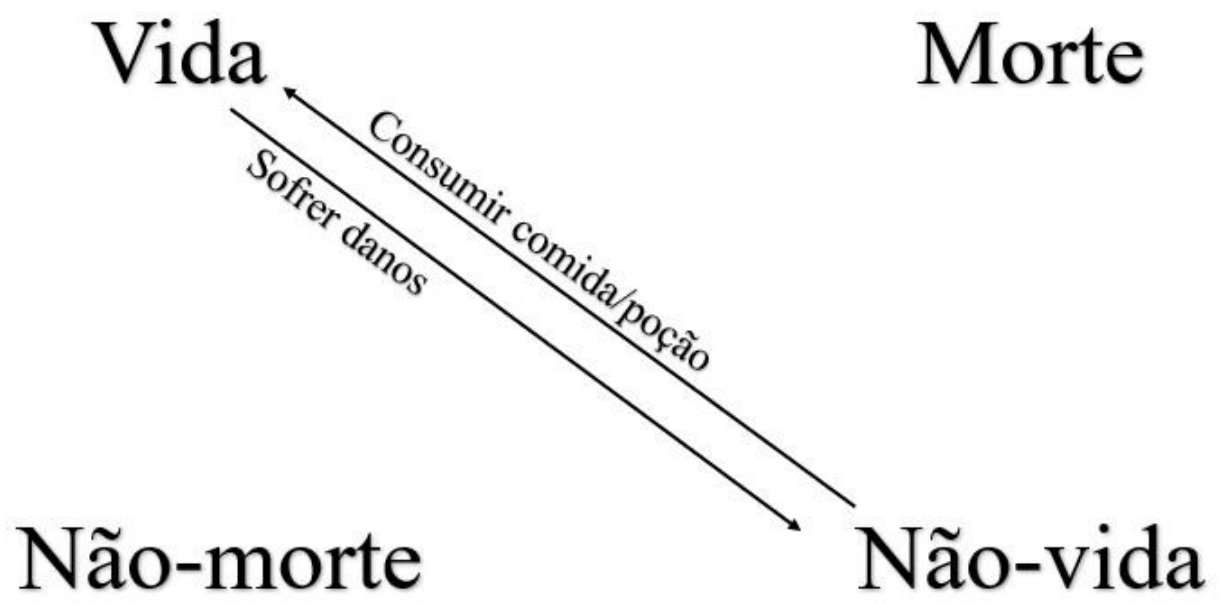

(Figuras 2.1 e 2.2 - Quadrado semiótico do sujeito)

Além de uma possível morte em combate, caso Geralt caia de uma altura elevada ou se mantenha submerso em água por muito tempo, a barra de vitalidade também se esvazia. 
No nível narrativo há o sujeito, representado pelo ator "Geralt", que também é o player character do jogo, ou seja, é o personagem que o jogador assume através do controlador, buscando conjungir com seu objeto de valor, representado pelo ator "Ciri". Por mais que a narrativa nos exponha a personagem do imperador Emhyr como pai biológico da garota, buscando em Geralt o único capaz de rastreá-la e contratando-o para isso, não consideramos o ator Emhyr como actante destinador do sujeito, pois o protagonista não demonstra qualquer intenção de levar a menina para ele. Geralt não vê Ciri há anos e consegue pressentir o perigo que a cerca. Ele quer salvá-la e também deve fazê-lo, motivando-se a si mesmo para tal. Consideramos então que o actante destinador e sujeito se convertem para o mesmo ator "Geralt" no programa narrativo de base presente em The Witcher III: Wild Hunt. Porém, o sujeito precisa adquirir competência para conseguir realizar a sua performance. O protagonista levou toda a vida como um grande guerreiro, enfrentando inúmeros monstros, o que indica que o sujeito da narrativa já é dotado de um poder-fazer, todavia, a localização de Ciri é desconhecida, o que vai obrigar Geralt a buscar um saber, destrinchando o programa narrativo de base em vários programas narrativos de uso.

O jogo proporciona em seu menu uma seção de missões, onde são exibidas todas as quests ${ }^{29}$ disponíveis. Algumas dessas missões podem ser consideradas PN's de uso com uma ligação mais importante com o PN de base, como por exemplo, Geralt ajudar o barão Phillipe Stranger em troca de informações do paradeiro de Ciri, porém, o jogo também disponibilizará ao jogador sidequests ${ }^{30}$.

Em meio a um cenário deplorado pela guerra entre duas grandes nações, muitas pessoas surgirão no caminho de Geralt implorando por seus favores, oferecendo-lhe dinheiro ou algum item que possa ajudá-lo. Essas missões secundárias possuem uma relação menos importante com o PN de base do jogo, porém, as recompensas geralmente são objetos de valor úteis ao sujeito.

\footnotetext{
${ }^{29}$ As quests, ou "missões", são uma maneira de orientar o jogador a dar continuidade à narrativa do jogo. Em jogos eletrônicos de RPG é comum o termo "main quest”, ou seja, a missão principal que envolve o enredo do jogo. As quests configuram programas narrativos de uso que constituem o programa narrativo de base, a main quest.

${ }^{30}$ São como missões secundárias. Nem sempre as sidequests têm ligação direta com o enredo principal do jogo, porém, às vezes oferecem narrativas próprias que servem para ambientar o jogador no universo criado no jogo. Funcionariam como programas narrativos menores, mas que, ainda assim, servem para que o sujeito adquira competência em sua jornada.
} 
O nível discursivo é recoberto de inúmeras figuras para ambientar o jogador enunciatário nesse mundo criado pela CD Projekt. Por tratarmos de um jogo eletrônico como texto sincrético, envolvendo linguagem verbal, escrita, visual e sonora, demonstraremos o revestimento figurativo tratando simultaneamente o plano da expressão de The Witcher III: Wild Hunt.

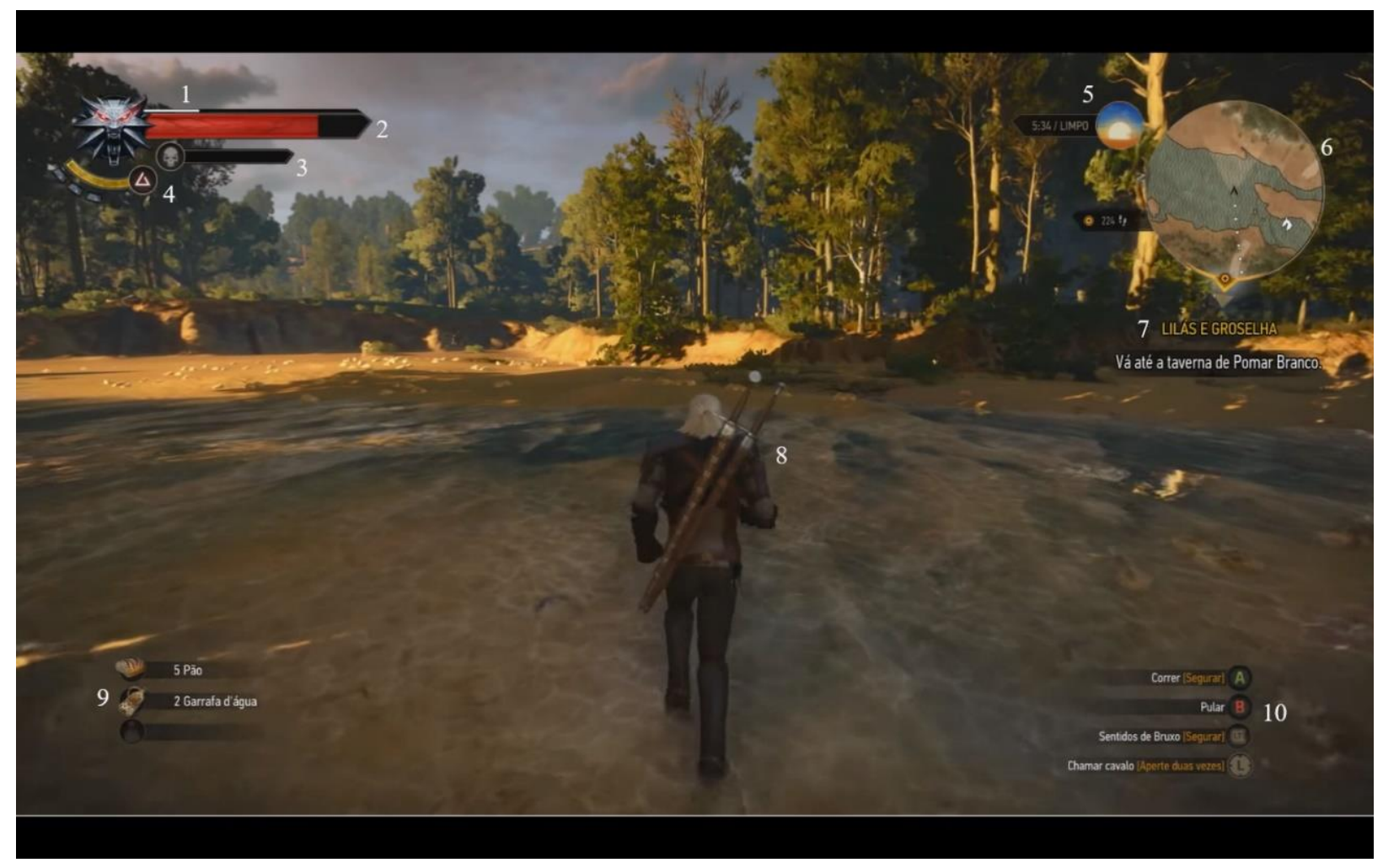

(Figura 2.3 - Interface de The Witcher III: Wild Hunt)

Inserimos, como um exemplo, uma captura de tela do jogo em funcionamento, adicionando números para cada recurso figurativo utilizado como indicador de uma função no jogo para manter o jogador enunciatário a par da situação de seu progresso.

O número 1 indica uma "barra de experiência". É através dela que o jogador sabe o quanto de pontos que o seu personagem já acumulou ao longo de sua jornada. $\mathrm{O}$ revestimento em branco vai se alongando conforme Geralt vai recebendo esses pontos, seja derrotando inimigos ou resolvendo missões. Assim que a barra fica completamente branca, o personagem sobe de nível, o que indica para o jogador que Geralt se tornou mais forte e ganhou uma nova habilidade, ou seja, adquiriu mais poder-fazer. 
A barra representada por 2 indica a vitalidade do personagem, como mencionado anteriormente. Imediatamente abaixo, temos 3, a "barra de intoxicação". Geralt sabe criar poções com flores e misturas químicas que o jogador pode fazê-lo coletar ao longo do jogo. Essas bebidas podem auxiliá-lo em suas performances, podendo deixá-lo mais forte temporariamente, mais rápido, fazê-lo enxergar no escuro ou respirar debaixo d’água, entretanto, consumi-las trará intoxicação ao personagem. A barra será preenchida pela cor verde a cada poção que o protagonista consome. Pelas regras do jogo, se tal barra estiver plenamente verde, ou seja, em 100\% de intoxicação, Geralt passará a perder/vida/ de sua barra de vitalidade, podendo, inclusive, chegar à /morte/.

A barra curva número 4 indica a quantidade de energia que o protagonista tem parar lançar um sinal. Na mitologia de The Witcher, os guerreiros como Geralt são capazes de criar pequenos efeitos mágicos não tão complexos, mas que podem ser essenciais para se defenderem. São eles:

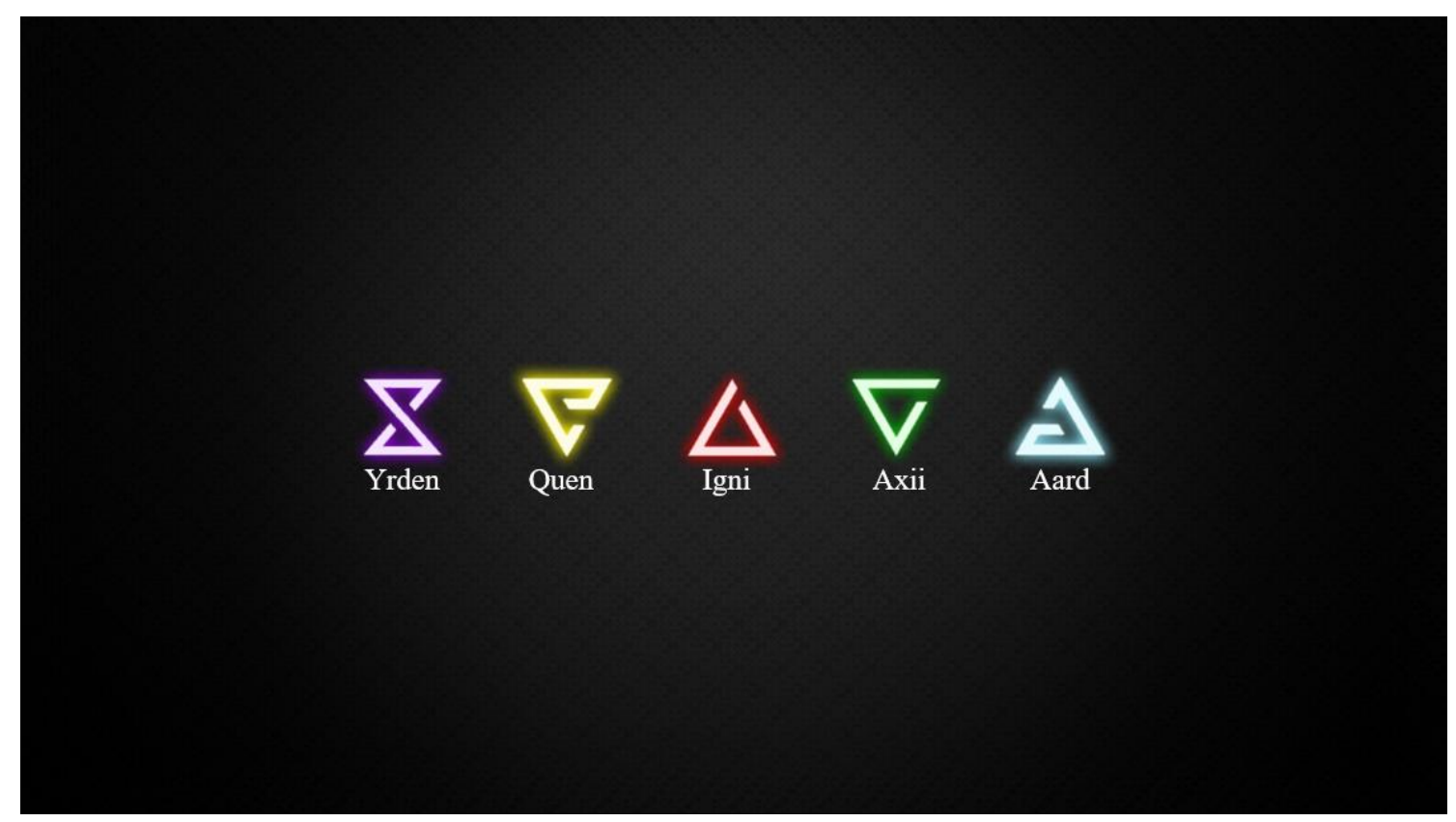

(Figura 2.4 - Os cinco sinais de The Witcher III: Wild Hunt. Adaptado de https://thewitcher.fandom.com/pt-br/wiki/Sinais, acesso em 21/01/2020.)

"Yrden" é a habilidade que Geralt tem de criar uma armadilha mágica no chão, desacelerando aqueles que entram em contato com ela. "Quen" é um revestimento do corpo do guerreiro, espécie de escudo mágico para proteger de grandes danos. "Igni”, 
semelhante à expressão latina ignis, é a capacidade que o protagonista tem de lançar labaredas de fogo momentaneamente pela mão esquerda. "Axii" é um sinal que, quando lançado, atordoa a mente de um inimigo, deixando-o confuso por alguns segundos. Finalmente, "Aard" é uma grande força que lança os inimigos para longe, afastando-os do protagonista, muito útil para quando este se encontra cercado.

A escolha de cores e de formas não é casual, já que é possível notar no símbolo de "Yrden", um sinal associado ao tempo, a figura de uma ampulheta, de "Quen", o sinal de proteção física, a figura de um escudo ogival e em “Aard", literalmente uma força para empurrar os oponentes, a figura da palma de uma mão. Além dos últimos, a opção da cor vermelho e de representar "Igni" com um triângulo apontando para cima, reforçam a ideia de "chama" por trás deste sinal.

Retomando o exemplo da interface do jogo, em 5 temos um espaço da tela dedicado a mostrar ao jogador em que momento do dia a ação do jogo está ocorrendo, representando o tempo narrativo do enunciado-jogo, sendo uma estratégia do enunciador de demonstrar a debreagem enunciativa de tempo.

$\mathrm{O}$ ícone 6 indica o mini mapa do jogo, incluindo um pequeno marcador em amarelo que denota ao jogador para qual direção deve conduzir o player character para dar continuidade à missão que está realizando, complementado pela legenda em 7 que indica o nome da missão (no caso da imagem, "Lilás e groselha"), também em amarelo, e o próximo objetivo para que a missão progrida ("Vá até a taverna de Pomar Branco").

Reforçamos, com inserção do número 8, o ponto de vista escolhido para se narrar o jogo The Witcher III: Wild Hunt. O enredo se volta para Geralt, em um jogo com perspectiva em terceira pessoa, ou seja, a câmera sempre acompanhará a ação mostrando o personagem de corpo inteiro, porém, assumindo uma distância fixa ${ }^{31}$, o que mantém a estratégia narrativa que esboçamos anteriormente no item $1.3^{32}$.

Por fim, temos em 9 os itens que estão à mão de Geralt para serem usados imediatamente, mais precisamente, pão e água, que, ao apertar de um botão no controlador, comanda o personagem a comer e regenerar sua barra de vitalidade. Para que

\footnotetext{
${ }^{31} \mathrm{O}$ sistema do jogo não permite o jogador dar um zoom out para analisar o cenário ou ver inimigos chegando pelas costas do personagem em um raio maior ao que a câmera mostra, por exemplo.

32 Conferir página 53 .
} 
o jogador não se esqueça das funções que cada botão do controlador exerce neste jogo, a própria interface exibe, como indicamos por 10, que ação cada botão específico representa. Tomando como exemplo o botão "A", checando a imagem, veremos a seguinte inscrição ao lado do símbolo "A": "Correr [segurar]", logo, para que o personagem corra no jogo, não só o jogador deve pressionar o botão "A” no controlador, como deve segurá-lo, mantendo-o apertado para baixo.

Outro recurso utilizado pela empresa produtora do jogo é o menu de pausa. Toda vez que, no decorrer do jogo, o jogador apertar o botão correspondente à pausa no controlador, deparar-se-á com a seguinte tela:

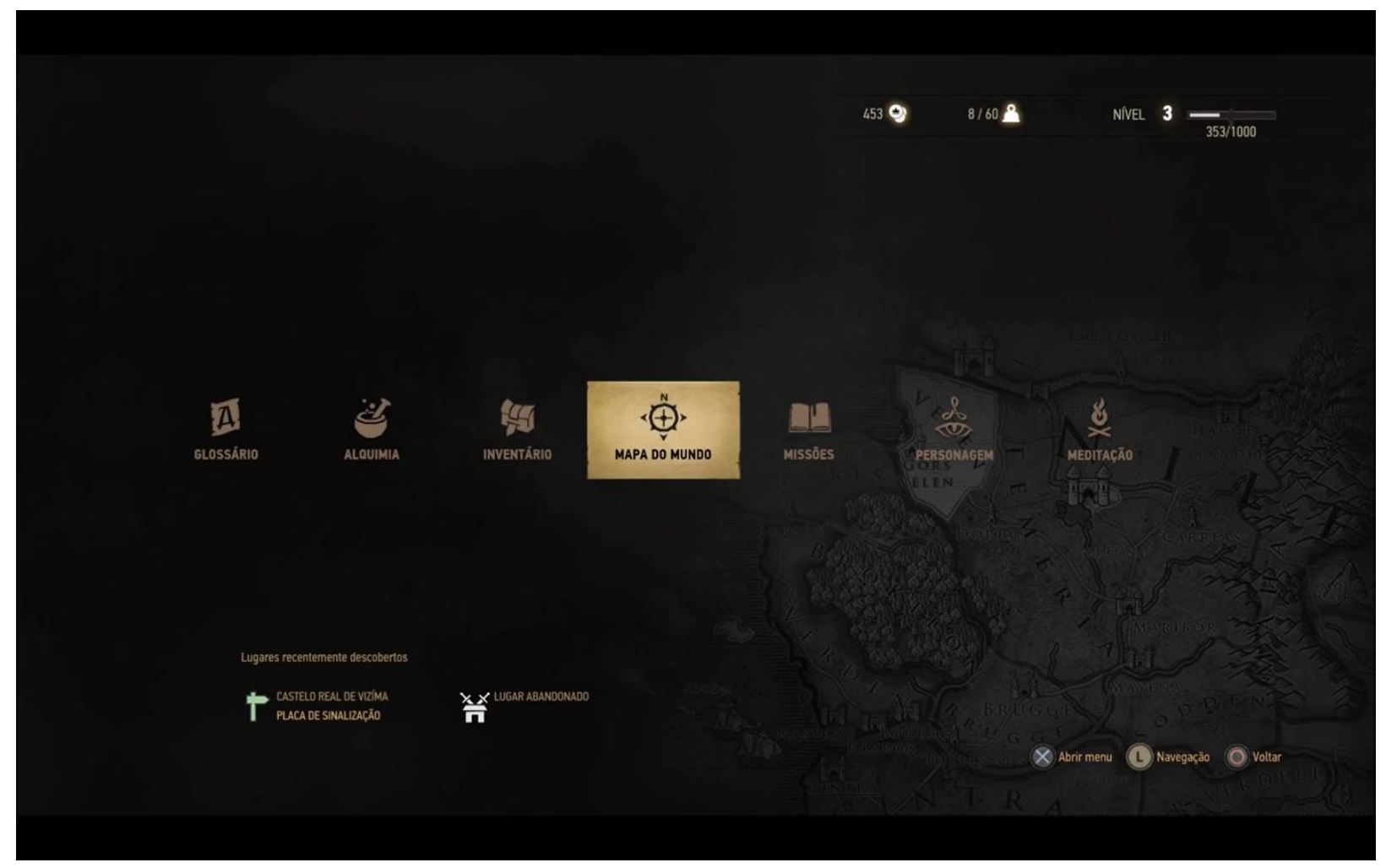

(Figura 2.5 - Menu de pausa de The Witcher 3: Wild Hunt.)

O menu de pausa serve para o jogador se manter imerso no que o jogo tem para lhe oferecer. Podemos ver sete ícones na imagem acima, cada um representando uma seção específica do menu. 
Ao selecionar "GLOSSÁRIO”, o ícone se desmembra em mais cinco: "bestiário", "tutorial”, "personagens", "livros" e "criação (de itens)".

O "bestiário" revela na tela uma lista de todas as criaturas que Geralt já enfrentou, dando informações ao jogador sobre o modus operandi de cada uma delas e as melhores estratégias para combatê-las. Enfrentando uma criatura nova e a derrotando, o jogador "desbloqueia" informações específicas dela no bestiário do jogo, uma maneira de o próprio jogo indicar que o sujeito da narrativa adquiriu mais competência do saber-fazer. “Tutorial” é um compilado de dicas que o próprio jogo exibe ao jogador quando este está vivenciando a experiência pela primeira vez, assim como "personagens" e "livros" são seções que exibem todo o conhecimento que Geralt acumulou sobre os personagens com quem interagiu e todo o conteúdo de pergaminhos e livros que obteve ao longo de sua empreitada. A seção "criação (de itens)" indica tudo que o protagonista sabe sobre como criar armas e armaduras no jogo. Geralt é um guerreiro, não um ferreiro, portanto, não tem o poder-fazer quando se trata de forjar armas mais poderosas, entretanto, vasculhando e encontrando diagramas ${ }^{33}$ de armas, pode acumular a matéria-prima necessária e contratar um ferreiro profissional para confeccionar o pedido desejado. Podemos afirmar que a seção "GLOSSÁRIO” do menu de pausa, então, informa ao jogador todo um saber que o sujeito protagonista acumulou do início de seu percurso narrativo até o momento em que o jogador pausa o jogo.

"ALQUIMIA" abre uma página com todas as receitas alquímicas que Geralt colheu ao longo de sua empreitada. Abaixo de cada poção específica será disposto a quantidade de itens para produzi-las. Caso os tenha em seu inventário, o protagonista consegue criar a poção em segundos.

"INVENTÁRIO” irá mostrar ao jogador todos os itens que Geralt está carregando consigo, seja em seus bolsos, ou atrelados à sela de seu cavalo. É a seção do menu que serve para o jogador comparar os itens que já obteve, como por exemplo, tipos de comida que regeneram a barra de vitalidade com mais rapidez, ou armaduras que oferecem mais proteção do que a que o player character estiver vestindo no momento.

\footnotetext{
${ }^{33}$ No jogo, são como pergaminhos que podem ser comprados em lojas ou encontrados em ruínas. Cada diagrama é como uma receita que indica a quantidade de ingredientes necessários para se forjar uma espada ou armadura específica, como por exemplo, o número de lingotes, tiras de couro e joias para a criação de uma espada mais resistente.
} 
Ao selecionar o ícone "MAPA DO MUNDO”, um grande mapa se abrirá na tela, informando a posição exata de Geralt em relação ao seu objetivo. Como mencionado anteriormente, o jogo utiliza de recursos figurativos como um marcador amarelo para indicar qual é a direção correta para o protagonista concluir missões. O mapa ainda exibe pequenos símbolos como exclamações (!) amarelas para o que são pessoas pedindo ajuda a Geralt e interrogações (?) brancas para pontos de interesse. Os últimos representam locais do mapa em que o jogador pode encontrar algum item ou algo semelhante que ajudará na jornada de Geralt. De modo geral, as interrogações brancas são inseridas em pontos remotos do mapa, uma forma do enunciador instigar o jogador enunciatário a explorar o universo do jogo.

Outro recurso presente no jogo é a "viagem rápida". Como The Witcher III: Wild Hunt é situado em um cenário expansivo, mover o player character do ponto A ao B pode se tornar uma experiência cansativa, dependendo da distância a se percorrer, logo, o jogo dispõe ao jogador a possibilidade de fazer viagens longas em segundos. Encontrando uma placa de encruzilhada, o personagem destrava um novo marcador de localização no mapa que pode ser usado futuramente para retornar ao local descoberto em poucos segundos.

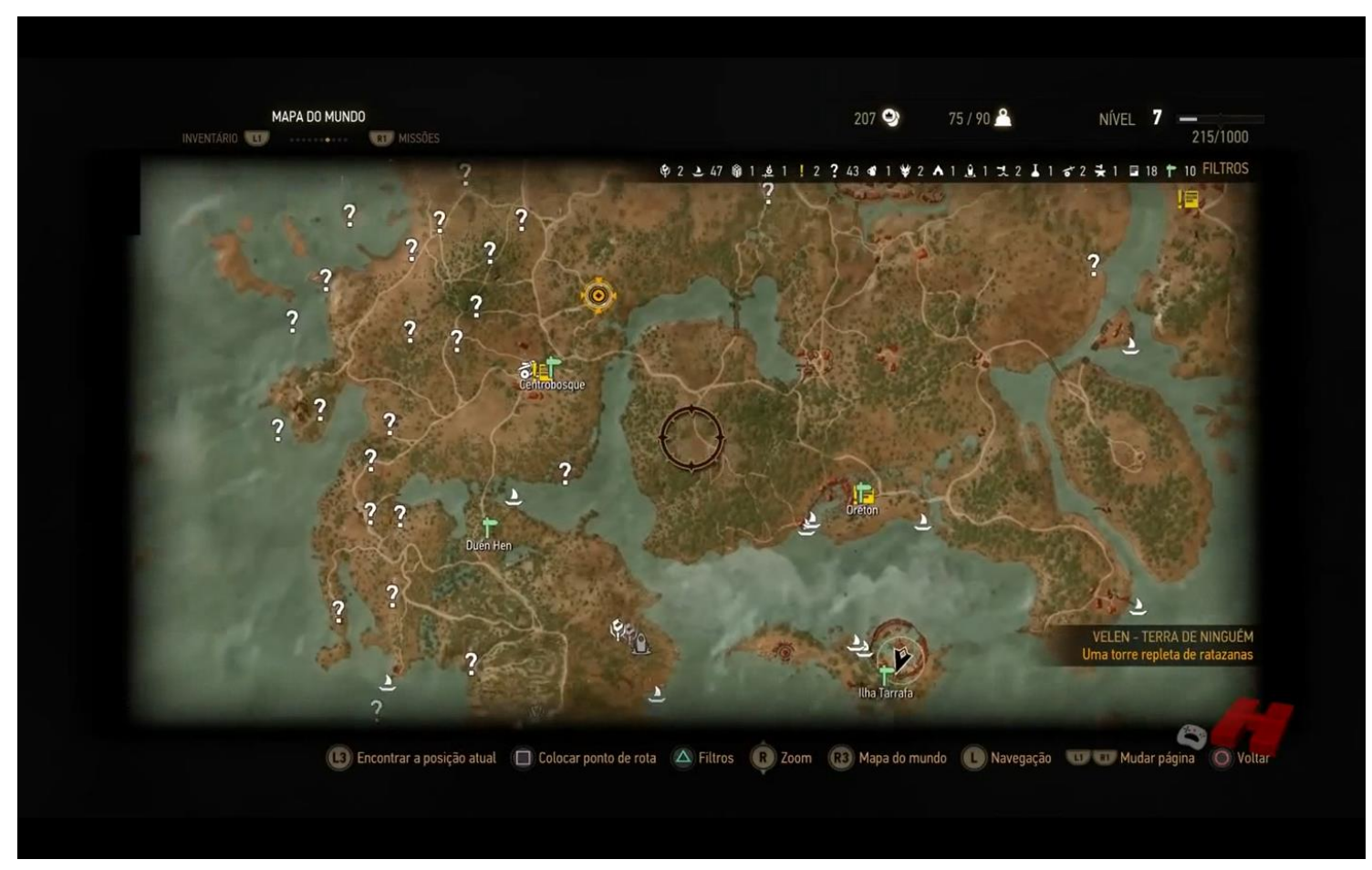

(Figura 2.6 - Mapa com marcadores de viagem rápida, representados por placas de direção.) 
Ao interagir com a placa, o mapa se abre na tela e o jogador pode escolher viajar rapidamente para os pontos representados por um marcador de cor verde. Na imagem acima temos as marcações de placa situadas sobre "Oreton", "Centrobosque" e "Ilha Tarrafa", vilarejos do mundo de The Witcher III. Pressionando o botão de ação com o cursor sobre uma dessas placas verdes, o jogador será redirecionado para uma tela de carregamento e então, quando o último for concluído, o player character estará no vilarejo ao qual o jogador desejava chegar.

O recurso de viagem rápida é uma maneira prática de o jogador voltar a regiões visitadas previamente sem ter que refazer todo o percurso, além de ser uma estratégia narrativa de encurtamento considerável do tempo e do espaço no jogo e mercadológica de dar ao jogador enunciatário o poder de não se entediar refazendo os caminhos já percorridos.

"MISSÕES" é uma forma de o jogador se manter conectado à narrativa do jogo, de modo que nesta seção ficam registradas todas as missões que já foram concluídas e as que ainda estão em andamento, inclusive indicando se fazem parte da quest principal (PN de base), ou se são missões secundárias (PN's de uso).

Em "PERSONAGEM", o jogador vislumbra as habilidades que Geralt pode melhorar conforme vai acumulando pontos e subindo níveis. Como já dito, a cada inimigo derrotado e missão concluída, recebem-se pontos que vão preenchendo a barra de experiência. Quando completa, o jogador recebe um "ponto de habilidade" que ele poderá usar para melhorar alguma das habilidades que Geralt possui, como por exemplo, intensificar a força de seu sinal Aard.

"MEDITAÇÃO" indica um poder-fazer do sujeito. Como bruxo, Geralt foi treinado para realizar seus contratos sempre friamente. Em certas circunstâncias, um monstro só ataca à noite, o que obriga o guerreiro a acampar próximo do habitat da criatura e aguardar a aparição dela. No jogo, a seção "MEDITAÇÃO” abre um timer, em que o jogador pode avançar o tempo narrativo, enquanto Geralt medita, desse modo, se for enfrentar uma monstruosidade noturna pela manhã, pode fazer com que o tempo passe rapidamente no jogo até cair a noite. Caso o jogador esteja vivenciando o jogo nas 
dificuldades "normal" ou "fácil", o ato de meditar também preencherá a barra de vitalidade do protagonista por completo.

\subsection{Um sujeito apassional?}

Descrito brevemente no item anterior, o protagonista da série de romances The Witcher é Geralt de Rívia, pertencente ao grupo de guerreiros, que passam por alterações genéticas, conhecidos como bruxos ${ }^{34}$, que são contratados para defenderem os humanos de monstros.

Como efeito colateral das mutações, os bruxos passam a carregar uma aparência soturna, de pele pálida e olhos de felino, e, segundo os romances, deixam de portar emoções. Geralt descreve o processo:

Foi ali que passei pela mutação habitual. Primeiro, a Prova das Ervas; depois, as coisas costumeiras: hormônios, infusões, infecções com vírus. E de novo. E mais uma vez. Até atingir o resultado desejado. Como suportei todas as mutações surpreendentemente bem e fiquei doente por pouco tempo, fui considerado um garoto de extrema resistência e escolhido para certos... experimentos mais complicados. Isso foi pior. Muito pior. Mas como pode ver, consegui resistir. Fui o único sobrevivente de todo o grupo que se submeteu aos tais experimentos mais avançados. (SAPKOWSKI, 2015a, p. 136-137).

Chama-nos a atenção o fato de o escritor polonês ter criado uma série com mais de sete livros tendo como personagem principal um sujeito "sem emoções". Os bruxos não deveriam ser cavaleiros que lutassem pelo bem, mas prestadores de serviço, que executariam sua vocação de caçadores de monstros por um preço estipulado e sem questionar. O próprio protagonista ainda diz em sua autodescrição, reproduzindo o que lhe ensinou seu superior: "Minha função não deveria ser a de me exibir, mas de executar as tarefas para as quais seria contratado em troca de uma remuneração" (Idem, p. 138).

\footnotetext{
${ }^{34} \mathrm{O}$ termo é o escolhido por Tomasz Barcinski, tradutor oficial da série, para dar lugar a "witcher". Apesar de o termo remeter à bruxaria, os bruxos do universo de Sapkowski não são capazes de conjurar grandes magias, de modo que a estes o autor escolhe o termo "feiticeiros".
} 
Desta maneira, fomos levados a um questionamento: Geralt poderia ser considerado um sujeito "apassional”?

A ideia de considerar um personagem sem qualquer manifestação passional não é completamente inconcebível, ainda mais no ramo do protagonista, onde deixar-se levar pelas emoções poderia afetar-lhe o raciocínio. Segundo José Luiz Fiorin, tradicionalmente,

Passional distingue-se do que é racional, lógico. Era preciso reprimir as paixões em nome da razão. A paixão continha os traços da loucura, da morte, da obscuridade, do caos, da desarmonia, da variabilidade, da particularidade, da irregularidade, da indistinção. (FIORIN, 2007, p. 9)

Ainda assim, em nenhum momento Sapkowski define Geralt como um ser sem paixões, mas caracteriza-o como sem emoções. Cabe a nós checar se os vocábulos, neste caso, estão inseridos no mesmo campo semântico. O Houaiss define emoção como "agitação de sentimentos; abalo afetivo ou moral; turbação, comoção" e paixão como "sentimento, gosto ou amor intensos a ponto de ofuscar a razão; grande entusiasmo por alguma coisa; atividade, hábito ou vício dominador" 35 . Os dois termos evidenciam a uma intensidade sensível que pode afetar a cognição. Em uma descrição pela visão semiótica de Fiorin, temos:

1) os termos afeto, sentimento e paixão são sinônimos no sentido geral e não são sinônimos no sentido especializado; 2) quando não são sinônimos, cada um indica um estado de alma diferente; 3) quando são sinônimos, designam um estado de alma em geral; 4) afetos, emoções paixões e sentimentos constituem o mesmo objeto teórico e, portanto, eles ocupam o mesmo lugar teórico. (Idem, p. 12).

Ancorados na definição dada acima, em um sentido geral, consideramos emoções e paixões como sinônimos no caso de Geralt de Rívia.

A difundida ausência de emoções cria na sociedade fictícia de Sapkowski um asco em relação aos bruxos, considerados matadores frios, mutantes que não tem lugar no meio

\footnotetext{
35 Ambas definições retiradas de https://houaiss.uol.com.br/pub/apps/www/v3-3/html/index.php\#5. Acesso em 21/01/2020.
} 
dos humanos. Um exemplo disso pode ser visto em um diálogo no capítulo inicial de $A$ espada do destino, segundo livro da série:

- Borch - falou o homem de cabelos brancos, virando-se de sua montaria e fitando o desconhecido diretamente nos olhos -, não gostaria que surgisse algum mal-entendido entre nós. Sou bruxo.

- Foi o que imaginei, mas percebi que você falou isso como se estivesse dizendo: "Sou leproso".

- Há pessoas - respondeu pausadamente Geralt - que prefeririam a companhia de um leproso à de um bruxo. (SAPKOWSKI, 2015b, p. 11, grifos nossos).

Outra maneira de o escritor polonês representar a ausência de paixões de Geralt é através da boca de outros personagens. Em um encontro com um gatuno excêntrico chamado Cigarra, Geralt é provocado:

- Por que você me provoca assim, Cigarra? O que você quer? Afinal, de que se trata?

- De nada. Apenas a curiosidade de quanto há de verdade naquilo que as pessoas falam de como vocês, bruxos, são valentes num combate por não terem coração, alma, misericórdia, nem mesmo consciência. (Idem, p. 106, grifos nossos).

Do ponto de vista de uma semiótica das paixões, o qual adotamos aqui, a paixão está relacionada aos "estados de alma” do sujeito, intensidade sensível que é regedora do inteligível, diferindo-se da emoção.

George Lakoff, linguista cognitivista, abordando a questão da sensibilidade como regedora da inteligibilidade, auxilia-nos:

E quanto à paixão? Você deve achar que emoção sempre atrapalha o caminho da razão, e geralmente atrapalha, mas, de fato, você não pode ser racional sem ser emocional. Isto foi descoberto por António Damásio. Ele tem um ótimo livro sobre o tema chamado $O$ erro de Descartes. Ele estudou pessoas que tiveram dano cerebral e acidentes vasculares cerebrais que destruíram a parte do cérebro que te permite sentir emoções e permite sentir as emoções de outras pessoas. (...) O que acontece é que você precisa de emoção para ter razão e é fácil saber o porquê. Imagine que você teve esse dano cerebral. Você não sente emoção, você não reconhece a emoção de ninguém mais. Como você saberia o que quer? Você gostaria disso ou não, já que gostar, ou não gostar, não significaria nada... E quanto a outras pessoas? Elas te odiaram, amariam, ou não se importariam? Você não saberia. 
Em resumo, você não saberia como decidir o que fazer em qualquer situação que envolvesse outra pessoa. Ou mesmo a si próprio. ${ }^{36}$

De acordo com o pronunciamento de Lakoff, a paixão também seria responsável por reger a nossa razão, ou seja, mesmo no caso de Geralt, seria algum estado patêmico que o impulsionaria a fazer o que faz.

Uma importante contribuição para o progresso da semiótica francesa foi $o$ adensamento da questão da tensividade nos textos. Claude Zilberberg (2011), ao desenvolver a teoria, afirma que os textos são regidos por uma cifra tensiva, representada por uma espécie de gráfico composto por dois eixos: a intensidade e a extensidade. A primeira é composta pela afetividade, pelos “estados de alma”, sendo a responsável por reger a segunda, denotada pelos "estados de coisas".

\footnotetext{
${ }^{36}$ Transcrição do texto original, pronunciado na comunicação intitulada The political mind: What about passion? You might think that emotion always gets in the way of reason, and often it does, but, in fact, you can't be rational without being emotional. That was discovered by Antonio Damasio. He has a great book on the subject called Descartes' error. He studied people who had brain damage and strokes that destroyed that part of the brain that allows you to feel emotion and allows you to feel what other people's emotions are. (...) It turns out you need emotional to be rational and it's easy to see why. Imagine that you had such brain damage, you can't feel emotion, you don't know what anybody else's emotion is, how would you know what to want? Would you like it, or not like it, if like it and not like it didn't mean anything... What about other people? Would they hate you, like you, not care? You wouldn't know. In short, you wouldn't know how to decide what to do in anything that involves any other person. Or maybe even yourself. (0:06:20 - 0:07:48). Disponível em:
}

http://library.fora.tv/2008/06/20/George_Lakoff_on_The_Political_Mind. Acesso em 20/07/2018. 


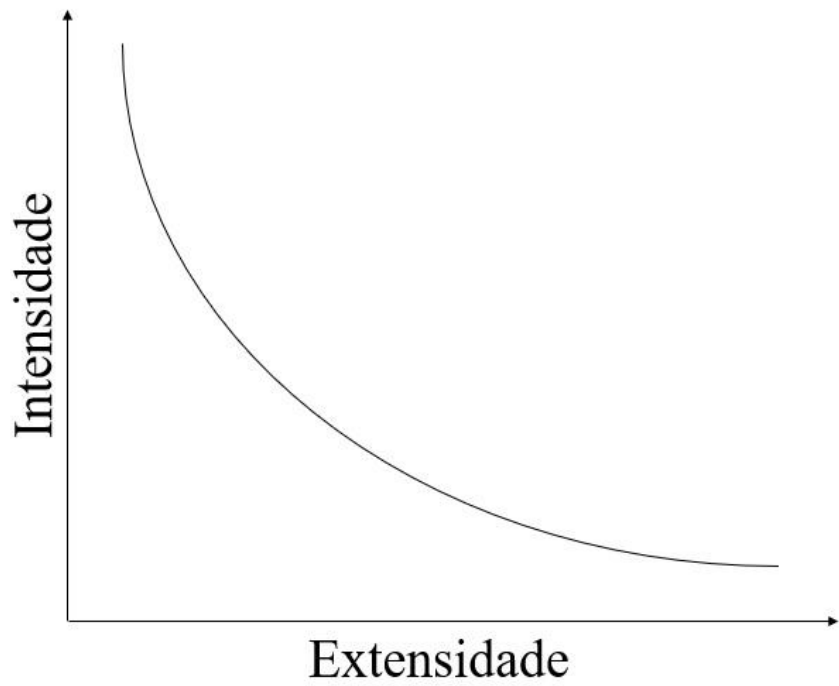

(Figura 2.7 - Cifra tensiva. Adaptado de ZILBERBERG (2011).)

Se um estado patêmico impulsiona o sujeito, mais precisamente, rege-o a fazer o que faz, qual paixão seria a regente em um indivíduo rotulado como "sem emoções"?

Em estudo publicado pela Actes semiotiques, Francesco Marsciani (1984) se dedica à exploração dos percursos passionais da indiferença. O semioticista se debruça sobre "O indiferente", de Marcel Proust, narrativa sobre Madeleine de Gouvres, moça distinta da sociedade que se apaixona por Lepré, rapaz que se manifesta indiferente ao seu charme. Marsciani volta o foco para Madeleine, considerando a manifestação de uma "indiferença narcísica":

O título da história, com a forma masculina do adjetivo, orienta a atenção no sentido da figura de Lepré e obriga a se considerar a indiferença como uma qualificação do comportamento da personagem masculina. No momento da terceira recusa, o narrador, em sincretismo com o observador-Madeleine, retorna a essa avaliação: "Então, repreendendo-o interiormente por sua indiferença, ela quis rever os homens apaixonados por ela"; mas, logo depois: “(...) ela quis rever os homens apaixonados por ela, com os quais ela tinha sido indiferente e atraente". Vê-se que ela também era (ou tinha sido) indiferente. E se nos voltamos para o início da história, a noite no teatro, percebemos que na primeira vez que a palavra "indiferença" aparece, ela se refere a Madeleine: "Logo, à feliz indiferença com a qual ela olhava suas graças desta noite nos olhos deslumbrados que as refletiam com uma fidelidade garantida, se misturaria a frustração de Lepré não a ter visto assim". Não existe apenas uma indiferença; a primeira indiferença que encontramos e, talvez, a mais importante, é a de Madeleine. (MARSCIANI, 1984, p. 7). ${ }^{37}$

\footnotetext{
37 Texto original:
} 
Marsciani, em sua análise, constata que, pela indiferença de Lepré, Madeleine não consegue discerni-lo como um sujeito-outro, ou antissujeito. Seu objetivo passa a ser, então, fazer Lepré crer que deve amá-la. No entanto, a indiferença do rapaz o leva a três recusas das investidas amorosas da moça, de modo que o amado vai à Ásia Menor sem ter instaurado qualquer relação com Madeleine. O semioticista italiano afirma, então, que a indiferença narcísica vem de Madeleine, mais complexa que a indiferença de Lepré, de modo que a moça se vê como a figura que faz a diferença em um ambiente indiferente, o que seria, de certo modo, inaceitável que a tratassem com indiferença.

\begin{abstract}
Nós já vimos quanto tinha sido necessário, para tornar possível a indiferença narcísica, que Madeleine assumisse a si mesma como alguém fazendo diferença no centro de um todo indiferenciado; nesse âmbito, o outro não faz diferença, ele participa de um estatuto imaginário no qual seu comportamento é previsível e previsto; é um simulacro interno ao programa do sujeito indiferente. Não apenas a indiferença é, nesse caso, uma indiferença genérica: tudo, o público, as flores, os reflexos de luminosidade, o ar, a companhia não têm outro meio de valerem que não em virtude de sua própria conformidade com os papéis atribuídos pelo sujeito narcísico, mas também não há mais espaço para as diferenças individuais: o outro não poder ser verdadeiramente considerado um objeto-valor porque o que é valorizado é a situação em si mesma, o fato de que o mundo gratifica o sujeito, o outro se reduzindo a esse mundo ficcional. A ruptura desse estado será a condição necessária para que um movimento passional se torne possível. (Idem, p. 30). ${ }^{38}$
\end{abstract}

Le titre du récit, avec la forme masculine de l'adjectif, oriente l'attention sur la figure de Lepré et oblige à considérer l'indifférence comme une qualification du comportement du personnage masculin. Au moment du troisième refus, le narrateur, en syncrétisme avec l'observateur-Madeleine, revient sur ce jugement : «Alors, lui reprochant intérieurement son indifférence, elle voulut revoir les hommes épris delle »; mais, toute de suite après : «(...) elle voulut revoir les hommes épris delle, avec qui elle avait été indifférente et coquette ». On voit qu'elle aussi était (ou avait été) indifferénte. Et si on se tourne vers le début du récit, la soirée au théâtre, on s'aperçoit que la première fois que le mot « indifférence » apparît, il se réfère déjà à Madeleine : «Bientôt, à l'indifférence heureuse avec laquelle elle mirait ses grâces de ce soir dans les yeux éblouis qui les reflétaint avec une fidélité certaine, se mêla le regret que Lepré ne l'ait pas vue ainsi ». Il n’y a pas qu'une indifférence : la première indifférence qu'on rencontre, et peut-être la plus importante, est celle de Madeleine. (Tradução feita por Thaís Janoti, que nos auxiliou com esta pesquisa). 38 Texto original:

Nous avons déjà vu combien il était nécessaire, pour rendre possible l'indifférence narcissique, que Madeleine s'assume elle-même comme faisant différence au centre d'un tout indifférencié ; dans se cadre, l'autre ne fait pas différence, il participe d'un statut imaginaire dans lequel son comportement est prévisible et prévu ; il est un simulacre interne au programme du sujet indifférent. Non seulement l'indifférence est en ce cas une indiférence générique : tout, le public, le fleurs, les reflets de luminosité, l'air, la compagnie n'ont d'autre moyen de valoir qu'en vertu de leur propre conformité aux rôles attribués par le sujet narcissique, mais il n'y a pas non plus de place pour les différences individuelles : l'autre ne peut être véritablement considéré comme un objet-valeur car ce qui est valorisé, c'est la situation elle-même, le fait que le monde gratifie le sujet, l'autre se réduisant à ce monde fonctionnel. La rupture de cet état sera la condition nécessaire pour qu'un movement passionnel devienne possible. (Tradução feita por Thaís Janoti, que nos auxiliou com esta pesquisa). 
Ancorados na análise de Marsciani, afirmamos que Geralt de Rívia, o protagonista "sem emoções", é, na verdade, regido pela paixão da indiferença.

No universo criado por Sapkowski, os bruxos são um grupo de guerreiros habilidosos, mas não podem ser comparados a paladinos da justiça. A motivação padrão de um bruxo vem do valor monetário de seu contrato. No capítulo "O bruxo", onde Geralt nos é apresentado na saga de Sapkowski, notamos a manifestação da indiferença em uma cena da qual o narrador se refere a ele como "desconhecido":

Um magricela bexiguento, que desde o momento em que o desconhecido entrara na taberna o observava soturnamente, levantou-se da mesa e aproximou-se do balcão. Dois de seus companheiros se postaram atrás, a menos de dois passos.

- Não ouviu que não há lugar aqui para tipos como você, seu vagabundo riviano? - rosnou o bexiguento, parando ao lado do desconhecido. - Aqui, em Wyzim, não precisamos de gente de sua laia. Esta é uma cidade decente!

O desconhecido pegou a caneca e se afastou, olhando para o taberneiro. (...)

- Pague a conta e suma daqui! - gritou o bexiguento.

Foi só então que o desconhecido olhou para ele.

- Primeiro, vou terminar minha cerveja.

- Pois nós vamos ajudá-lo - sibilou o magricela, que arrancou a caneca da mão do riviano e, agarrando-o pelo braço, enfiou os dedos por trás da tira de couro que atravessava o peito do desconhecido. Um de seus comparsas preparava-se para desferir um soco. $\mathrm{O}$ estranho girou sobre os calcanhares, fazendo o bexiguento perder o equilíbrio. A espada sibilou de dentro da bainha e por um breve momento brilhou à luz das lamparinas. $\mathrm{O}$ ambiente fervilhou. Alguém gritou. Um dos fregueses se precipitou para fora. Uma cadeira desabou e recipientes de barro estilhaçaram. O taberneiro, com lábios trêmulos, ficou olhando para o horrivelmente destroçado rosto do bexiguento, que, desprendendo aos poucos os dedos da beira do balcão, deslizou para baixo, sumindo como se estivesse se afogando. Os outros dois jaziam no chão, um deles imóvel, o outro se agitando convulsivamente no meio de uma poça escura cada vez maior. (SAPKOWSKI, 2015a, p. 10-11).

Nota-se que, apesar de muito superior em questões físicas, já que Geralt possui as mutações genéticas da Prova das Ervas, tornando-o mais forte e veloz, poderia somente nocautear os baderneiros, no entanto, o protagonista mata friamente os três homens. Após o conflito, que deixa um incontável número de testemunhas amedrontadas, o sujeito é levado por três guardas para ser julgado pelo chefe do vilarejo. 
O desconhecido sentou-se. Já não portava a espada nem a capa preta.

- Sou todo ouvidos - disse Velerad, brincando com uma pesada maça pousada no tampo da mesa. - Sou Velerad, o estaroste ${ }^{39}$ de Wyzim. O que tem a dizer, senhor bandido, antes de ser despachado para as masmorras? Três mortos e uma tentativa de enfeitiçamento... Nada mal, nada mal. Aqui, em Wyzim, costumamos empalar os culpados por esse tipo de coisas. Mas como sou um homem justo, pretendo ouvi-lo antes. Portanto, fale.

O riviano abriu a jaqueta e tirou um pergaminho de pele de cabra branca.

- Vocês têm afixado isto nas tabernas e nas encruzilhadas - falou baixinho. - É verdade o que está escrito aqui?

- Ah - murmurou Velerad, olhando para as runas gravadas no pedaço de pele. - Então é disso que se trata. Devia ter adivinhado. Sim, é a mais pura verdade. O pergaminho está assinado por Foltest, rei de Temeria, Ponatar e Mahakam, o que significa que é verdadeiro. Mas uma proclamação é uma proclamação e leis são leis. Meu papel aqui, em Wyzim, é fazer com que as leis sejam cumpridas, e não vou permitir que pessoas sejam assassinadas sem mais nem menos! Deu para entender?

O riviano assentiu com a cabeça, demonstrando que entendera. Velerad resfolegou furiosamente.

- Você tem divisa de bruxo? - indagou.

O desconhecido voltou a enfiar a mão na jaqueta, dessa vez retirando um medalhão redondo pendurado numa corrente de prata. Nele estava gravada a cabeça de um lobo com as presas arreganhadas.

- E você tem nome? Pode ser qualquer um. Não estou perguntando por curiosidade, mas para facilitar nossa conversa.

- Meu nome é Geralt.

- Pois que seja Geralt. De Rívia, como deduzo por seu sotaque.

- De Rívia.

- Sabe de uma coisa, Geralt? Não se envolva neste assunto - disse Velerad, batendo com a mão na proclamação. - É um caso bastante sério. Muitos já tentaram. Isso, meu irmãozinho, não é o mesmo que arrebentar a cabeça de um par de patifes.

- Estou ciente disso. É a minha profissão, senhor estaroste. Na proclamação está escrito: três mil ducados de recompensa.

- Três mil - confirmou Velerad, de boca cheia. - E mais a mão da princesa, segundo dizem por aí, embora nosso amado Foltest não tenha acrescentado isso à proclamação.

- Não estou interessado na princesa - falou calmamente Geralt, sentado imóvel, com as mãos sobre os joelhos. - O importante é o que está escrito: três mil ducados. (Idem, p.1214)

\footnotetext{
${ }^{39}$ Chefe de uma comunidade, espécie de fidalgo polonês. (https://www.google.com/search?q=dicionario+estaroste\&oq=dicionario+estaroste\&aqs=chrome..69i57j0 15.3339j0j8\&sourceid=chrome\&ie=UTF-8, acesso em 21/01/2020)
} 
No excerto é possível ver como a paixão da indiferença rege o sujeito. Geralt assassinara três homens para chegar ao chefe de Wyzim, para então apresentar-lhe a proclamação do rei e se informar. Tirar a vida dos baderneiros fora só um detalhe para ele. Além disso, é nítida a única motivação do personagem para se informar sobre o novo contrato: somente os três mil ducados lhe interessam. Podemos afirmar que Geralt também é regido pela indiferença, não da mesma forma que Madeleine, mas modalizado por um "poder não ser". Para o sujeito, não importam as consequências de suas ações, contanto que conjunja com o seu objeto de valor, dessa forma, sendo rotulado pela sociedade como "sem emoções".

Apesar disso, a indiferença não é a única paixão que rege o protagonista. Em meio a muitas de suas aventuras, Geralt acaba conhecendo uma feiticeira ${ }^{40}$ que é completamente diferente de todas as mulheres com quem ele já se relacionou. Seu nome é Yennefer e ela tem uma personalidade fortíssima, é independente e sabe como chegar aos seus objetivos sem o auxílio de ninguém. O protagonista e a feiticeira acabam se envolvendo e começando uma relação, mas nenhum admite que há amor no processo. Em dado momento do desenrolar da narrativa, Yennefer precisa resolver assuntos com um colega da casta dos feiticeiros, chamado Istredd, de modo que o casal decide se hospedar em uma estalagem na cidade onde o mago reside. Trabalhando para o chefe da comunidade, Geralt é informado de que sua companheira visita Istredd com frequência, tornando-se desconfiado. A partir desse instante, o protagonista "apassional" começa a se configurar como ciumento.

Segundo Greimas e Fontanille, a paixão do ciúme comporta "três atores: o ciumento, o objeto, o rival" (1993, p. 171). Geralt decide investigar a situação e visita Istredd em sua casa. Apesar de nunca o ter visto, o próprio fato de Istredd ser um colega antigo de Yennefer já configura uma ameaça para o caçador de monstros.

o temor de perder o objeto só se compreende aqui em presença de um rival ao menos potencial ou imaginário, e o temor do rival nasce da presença do objeto de valor que funciona como pivô. (GREIMAS; FONTANILLE, 1993, p. 171).

\footnotetext{
${ }^{40}$ Conferir Nota de rodapé $n^{\circ} 34$.
} 
Feiticeiros são muito mais poderosos do que Geralt, o que torna Istredd um perigoso rival potencial em sua relação com Yennefer.

Chegando lá, o protagonista e o feiticeiro começam a discutir sobre Yennefer e uma tensão se instaura, pois Geralt descobre que sua companheira já teve uma relação com Istredd no passado.

- Minha relação com Yennefer - continuou o feiticeiro - é antiga, bruxo. Por bastante tempo foi uma relação sem comprometimento, que consistiu em longos ou curtos períodos mais ou menos regulares nos quais estivemos juntos. Tal tipo de parceria descomprometida é muito frequente entre as pessoas de nossa profissão. Acontece que esse arranjo deixou de me satisfazer e, diante disso, decidi propor-lhe que ficasse comigo permanentemente.

- E o que ela respondeu?

- Que pensará no assunto. Dei-lhe bastante tempo para pensar, porque eu sei que não será uma decisão muito fácil para ela.

- Por que me conta isso tudo, Istredd? O que o motivou, além de uma louvável, porém surpreendente sinceridade, característica tão rara entre vocês, feiticeiros? Qual o objetivo dessa sua sinceridade?

- Um objetivo prosaico - suspirou Istredd. - É que sua pessoa dificulta Yennefer tomar uma decisão. E, assim, peço-lhe que tenha a bondade de se afastar. Que você suma da vida dela e pare de atrapalhar. Em poucas palavras: que vá para o inferno. (SAPKOWSKI, 2015b, p. 111)

Em meio ao duelo verbal, Geralt se impõe contra o feiticeiro.

- Meu desejo, Istredd (...) é que você pare de se meter entre Yennefer e mim. Estou me lixando para suas propostas a ela. Poderia tê-las feito antes, quando ela esteve com você. Porque antes foi antes, e agora é agora. Agora ela está comigo. Quer que eu me afaste e deixe o caminho livre para você? Esqueça. Recuso-me. E não só me recuso a ajudá-lo, como vou fazer de tudo para atrapalhá-lo, dentro de minhas limitações. (Idem, p. 112).

O que podemos notar é que ambos, Geralt e Istredd, são sujeitos lutando pela posse exclusiva de um objeto de valor que para eles é eufórico, o que faz parte do perfil do sujeito ciumento. Ainda nos apoiando em Semiótica das paixões, temos: 
A "possessão" seria a "faculdade de usar um bem de que se dispõe", e remeteria assim a "deter", "servir-se de", "ter prazer de". O sujeito da possessão não é um sujeito de fazer que visa à conjunção, mas um sujeito já conjunto que visa ao prazer de seu objeto. Percebe-se também um sujeito de fazer que dá prazer ao sujeito de estado, mas estaria situado na dimensão tímica, e não mais na dimensão pragmática, que levou à conjunção com o objeto: escolhe-se e compra-se uma casa (dimensão pragmática) e sente-se prazer quando se dispõe dela (dimensão tímica). Uma vez conjunto ao sujeito, o objeto perde de algum modo seus status pragmático e transforma-se em objeto tímico, objeto de prazer que é fonte de euforia (GREIMAS; FONTANILLE, 1993, p. 185).

Geralt havia se relacionado com outras mulheres antes de Yennefer, no entanto, as relações se assemelham ao exemplo da compra da casa, presente na citação acima. $O$ envolvimento do protagonista com as mulheres anteriores teria somente um fim pragmático para ele, enquanto que, com Yennefer, a conjunção com o objeto de valor passou a despertar nele euforia, ou seja, já se configurou como um vínculo da dimensão tímica, e é por tal motivo que o bruxo teme a presença de Istredd.

Aqui já teríamos argumento para demonstrar que Geralt não é "apassional". No entanto, para refinamento da análise, contemplaremos o desfecho do embate entre os rivais.

Em meio à acalorada discussão, Geralt e Istredd jogam as cartadas finais, configurando o auge da rivalidade:

- Basta! - interrompeu-o Geralt de maneira rude, talvez rude demais. - Pare de insistir em me negar direitos, porque estou farto disso, ouviu? Já lhe disse que nossos direitos são os mesmos. Aliás, não, com todos os diabos. Os meus são maiores.

- Realmente? - O feiticeiro empalideceu levemente, o que fez Geralt sentir uma indescritível satisfação. - E posso saber por quê?

$\mathrm{O}$ bruxo pensou por um momento e resolveu acabar com ele de vez.

- Pelo simples fato - disparou - de ela ter feito amor comigo na noite passada, e não com você.

Istredd puxou a caveira para junto de si e acariciou-a. Sua mão, para o desgosto de Geralt, não tremeu nem um pouquinho.

- E você acha que tal fato lhe dá algum direito?

- Apenas um: o de tirar conclusões.

- Entendo - disse o feiticeiro. - Que seja. Pois saiba que ela fez amor comigo hoje, antes do almoço. Tire daí suas conclusões, já que diz que tem o direito. Eu tirei as minhas. (SAPKOWSKI, 2015b, p. 114-115, grifos nossos). 
Com ambos crendo serem os verdadeiros amados de Yennefer, o diálogo cessa. Geralt retorna à estalagem e encontra sua companheira. Em uma discussão, o bruxo teme perguntar à feiticeira se ela o ama, ao mesmo tempo que Yennefer não tem forças de admitir o sentimento, dizendo que ambos Geralt e Istredd são extremamente importantes para ela.

Como é desejoso da exclusividade de seu objeto de valor, o protagonista volta a encontrar seu rival no dia seguinte, de modo que os inimigos mantêm a ferocidade recíproca:

Istredd apoiou os punhos nos quadris e olhou para o bruxo de maneira provocativa.

- Não nos enganemos - falou. - Você me odeia e eu o odeio. Você me afrontou ao dizer que Yennefer... você sabe o quê... e eu lhe respondi com a mesma afronta. Você me atrapalha e eu o atrapalho. Vamos resolver isso como homens. Não vejo outra solução. Foi para isso que você veio aqui, não é verdade?

- Sim - respondeu Geralt, esfregando a testa. - Você está certo, Istredd. Foi para isso que eu vim aqui. Sem dúvida alguma.

- E agiu certo. Essa situação não pode continuar assim. Somente hoje descobri que há vários anos Yenna tem circulado entre nós como uma bola de pano. Ora está comigo, ora com você. Foge de mim para sair a sua procura, e vice-versa. Os outros, com quais ela fica nos intervalos, não contam. Os únicos que estão em jogo são você e eu, e essa situação não pode persistir. Somos dois e terá de sobrar só um.

- Sim - repetiu Geralt, esfregando a testa mais uma vez. - Sim... Você está certo. (Idem, p. 122, grifos nossos).

O que se pode notar no segundo embate verbal entre os contestantes é que ambos estão cientes de que Yennefer se relaciona com outros homens além deles, no entanto, a causa do embate não é a exclusividade do sexo com a feiticeira, o que seria um fim pragmático, mas sim a exclusividade do seu amor, que é fonte de euforia para os dois rivais.

Em Semiótica das paixões, Greimas e Fontanille propõem um esquema passional canônico, composto por etapas (constituição - sensibilização, que se desdobra em disposição - patemização - emoção, - moralização) (1993, p. 244). Apoiando-nos também em Eliane Soares de Lima, temos: 
Nessa primeira posição do esquema passional canônico, Greimas e Fontanille (1993) definem a etapa da constituição como sendo um determinismo do sujeito: social, psicológico, hereditário, ou qualquer outro, mas sempre anterior a toda competência e disposição, típicas à instauração do sujeito apaixonado. (LIMA, 2017, p. 857).

Greimas e Fontanille ainda nos auxiliam:

Chamar-se-á constituição a etapa correspondente à reembreagem, em que é definido previamente o estilo tensivo do sujeito apaixonado, que assume a forma, no caso do ciúme, de uma oscilação tímica que não consegue polarizar-se. (...) A constituição do sujeito apaixonado é, pois, a fase que concede ao conjunto do processo seu estilo semiótico. (GREIMAS, FONTANILLE, 1993, p. 243).

Ainda sobre o esquema passional canônico:

O estágio da sensibilização, articulado pelas fases da disposição, da patemização e da emoção, corresponde, dessa forma, à manifestação da paixão propriamente dita, passível de ser descrita (LIMA, 2017, p. 858).

A sensibilização representa um comportamento relativo a determinada paixão que é estereotipado em certa cultura. Greimas e Fontanille descrevem semioticamente o que caracteriza a paixão e o comportamento do ciumento, que já comentamos anteriormente (sujeito com receio de que um rival tome o seu objeto de valor). O desejo de exclusividade do objeto de valor já denotaria a disposição de Geralt em manifestar o ciúme.

Sua patemização, momento de crise passional, é demonstrada pela maneira como lida com a presença de seu rival, tratando Istredd como um verdadeiro inimigo e ainda concordando em duelar até a morte com ele. A completa eliminação do rival, no caso de Istredd, literal, seria para Geralt uma garantia de que a posse de seu objeto de valor não seria mais ameaçada.

Em relação à emoção, sabemos que é caracterizada como uma expressão somática. O corpo fala, e através da observação dele é possível reconhecer certa paixão segundo as suas características consideradas por determinada cultura. No caso do bruxo 
de Sapkowski, geneticamente modificado para ser não-emocional, raramente há uma manifestação corporal como o choro ou uma gargalhada, mas, no capítulo específico desta análise, nota-se uma inconformidade por parte de Geralt em saber que não é o único indivíduo amado por Yennefer, demonstrando nitidamente a insatisfação no seu rosto, quando discutindo com ela:

Sem dizer uma palavra, Yennefer sentou-se à mesa, apoiando o queixo nas mãos entrelaçadas.

- Muito bem. Comecemos. - falou. - Este silêncio prolongado cheio de dramaticidade é banal demais para mim. Vamos resolver isso de uma vez. Levante-se da cama e pare de olhar para o teto com cara de ofendido. A situação já é bastante complicada e não há por que complicá-la ainda mais. Vamos, levante-se.

Geralt ergueu-se obedientemente, sentando-se ao contrário numa tosca cadeira de madeira, montando nela como num cavalo e apoiando os braços no encosto. Yennefer não evitou seu olhar, algo que ele já esperava. (SAPKOWSKI, 2015b, p. 116, grifos nossos).

Quanto ao último estágio do esquema passional, temos:

Enfim, a emoção manifesta-se por um comportamento observável, que é o objeto principal das avaliações éticas e estéticas que convencionamos chamar moralização. (GREIMAS; FONTANILLE, 1993, p. 244).

As avaliações éticas e estéticas de que falam Greimas e Fontanille seriam uma sanção cognitiva sobre o sujeito apaixonado. No caso do embate entre Geralt e Istredd, ambos sancionam a si mesmos:

Os dois futuros contendedores ficaram parados um diante do outro por um instante sem se olhar. Por fim, o feiticeiro murmurou algo inaudível, chutou um torrão e despedaçouo com o salto da bota.

- Geralt?

- Sim?

- Você não se sente um idiota?

- Sinto-me um idiota - admitiu o bruxo, meio a contragosto. 
- Ainda bem - disse Istredd. - Fico aliviado, porque me sinto o maior cretino do mundo. Nunca imaginei que teria de travar uma luta de vida ou morte com um bruxo por causa de uma mulher.

- Sei como você se sente, Istredd. (SAPKOWSKI, 2015b, p. 124, grifos nossos).

Notamos que ambos rivais se sancionam negativamente pelas ações que o ciúme os levará a cometer. Apesar de Geralt e Istredd se odiarem mortalmente e combinarem um duelo até a morte no dia seguinte, Sapkowski dá um fim inesperado para a história.

O sofrimento de Geralt em saber que não tem o amor exclusivo da feiticeira o leva a tentar cometer suicídio, pedindo para um grupo de bandidos o espancarem até a morte. Entretanto, quando um dos bandidos visualiza o medalhão de bruxo de Geralt, bate em retirada e leva os outros criminosos consigo, temendo sofrer alguma maldição. Diante disso, Geralt decide se encontrar com Istredd no dia seguinte.

Para a surpresa do bruxo, Istredd decide lutar sem usar magia, o que acarretaria em derrota certa. O feiticeiro revela então que Yennefer lhe enviou uma carta, informando que o deixara. Geralt conclui que, igualmente a ele, Istredd também não conseguiria aceitar a perda da exclusividade de seu objeto de valor, desejando a morte. E então, o embate entre os rivais termina:

- Está esperando o quê? - rosnou o feiticeiro.

O bruxo ergueu lentamente a cabeça, olhou para o adversário por um momento e, girando sobre os calcanhares, começou a se afastar.

- Não, Istredd - sussurrou. - Adeus.

- O que significa isso, com todos os diabos?

Geralt parou.

- Istredd - falou por cima do ombro. - Não envolva outras pessoas nisso. Se tiver de fazêlo, enforque-se nos arreios numa cocheira.

(...) $\mathrm{O}$ bruxo entrou na ruela, sem se virar mais. Foi andando sem dar atenção às pessoas que rapidamente se afastavam a sua passagem, nem ao som de portas e janelas sendo fechadas às pressas. Não notava nada nem ninguém.

Pensava na carta que o aguardava na estalagem. (Idem, p. 132). 
Tomando como foco o ciúme, pudemos notar que, mesmo caracterizando-o majoritariamente como indiferente, o protagonista dos romances de Andrzej Sapkowski se adequou a todos os estágios do esquema passional canônico de Greimas e Fontanille, configurando-se como sujeito ciumento, no capítulo que escolhemos analisar.

Apesar de termos demonstrado a manifestação passional em Geralt nos romances de Sapkowski, nosso principal objeto de análise para esta pesquisa é o enredo presente no jogo The Witcher III: Wild Hunt. Antes de nos debruçarmos sobre as peripécias do bruxo nos games, há de se ressaltar que a empresa CD Projekt comprou os direitos sobre a propriedade intelectual de Andrzej Sapkowski, produzindo a franquia de jogos The Witcher a partir de 2007. Como mencionado neste capítulo, o RPG de ação não seria uma paráfrase da narrativa encontrada nos livros, mas sim, uma continuação do seu enredo.

Em The Witcher III: Wild Hunt, atualmente constatado como o jogo conclusivo da série, Geralt busca reencontrar sua pupila e filha adotiva, Ciri, que possui um poder ancestral único, tornando-a alvo de várias figuras poderosas que desejam tomar-lhe este dom.

Basicamente, o programa narrativo da história é constituído por Geralt em busca de Ciri. Ele quer e deve encontrá-la, mas não sabe como. A narrativa do jogo se desenrola enquanto o jogador, personificando Geralt, vai cumprindo favores para barões, reis e burgomestres em troca de informação da localização de sua filha. A garota é alvo da Caçada Selvagem, um grupo de cavaleiros sobrenaturais que visa sequestrá-la e usar o seu talento para o mal. Em meio à fuga constante, Ciri se envolve com feiticeiros e bandidos que acabam lhe causando mais problemas do que apoio.

Seguindo o rastro da pupila, Geralt adentra a cidade de Novigrad. Lá, ele descobre que sua aluna teve contato com o personagem nomeado Filho da Puta Júnior, um dos quatro chefões do crime. Em uma tentativa de contatá-los para acumular mais informações, Geralt acaba se inserindo em uma verdadeira guerra civil entre eles, já que Willy Cipriano, que é o chamado Filho da Puta Júnior, decidiu trair os outros três. Orientado por um deles, Geralt busca encontrar Willy para saber do paradeiro da filha adotiva. Em sua empreitada, o chefão manda vários subordinados assassinarem o protagonista. Com o desenrolar das investigações, o bruxo descobre que Júnior estava tentando uma aliança com o rei Radovid para controlar a cidade, no entanto, chegando ao 
rei, este informa que o chefão do crime perdera a utilidade em certo momento e revela a localização exata do malfeitor para Geralt.

Apesar de ter enfrentado inúmeros capangas, o protagonista quer somente a informação do paradeiro de Ciri. Até a chegada do esconderijo de Júnior, Geralt se configura como um sujeito em busca de um saber, enfrentando oponentes enviados pelo chefão do crime, que foi o último a ter contato com a garota. No entanto, o intuito do protagonista muda quando ele vê como Willy trata as mulheres que são mandadas para a sua mansão (ver Figura 2.8).

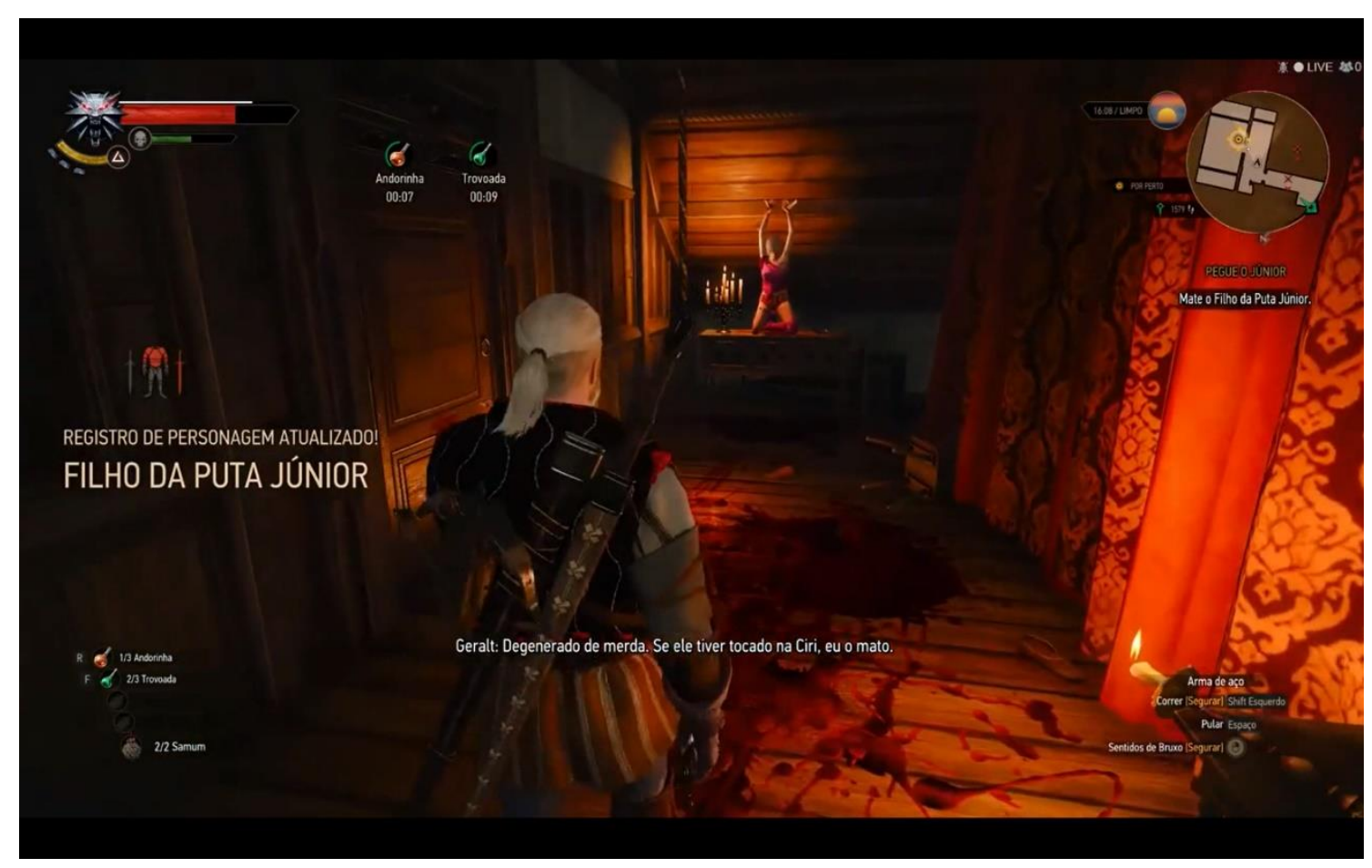

(Figura 2.8 - Geralt vê as atrocidades cometidas por Willy e diz: "Degenerado de merda. Se ele tiver tocado na Ciri, eu o mato.")

Próximo de adentrar o quarto de Willy, Geralt encontra uma grande quantidade de manchas de sangue no assoalho e dá de cara com uma meretriz pregada à parede. Em choque, teme por Ciri. Neste momento, consideramos que Geralt sofre uma surpresa disfórica e que seu programa narrativo é momentaneamente interrompido por um “acontecimento" (ZILBERBERG, 2011) que lhe sobrevém. 
Segundo Claude Zilberberg, "o acontecimento não poderia seriamente ser visado, ou seja, antecipado. Dito de modo familiar: quando a coisa acontece, já é tarde demais!" (Idem, p. 169), o que se aplica ao percurso de Geralt. A tensão se instala, aumentando consideravelmente a tonicidade e o andamento, de modo que a temporalidade e a espacialidade quase se nulificam.

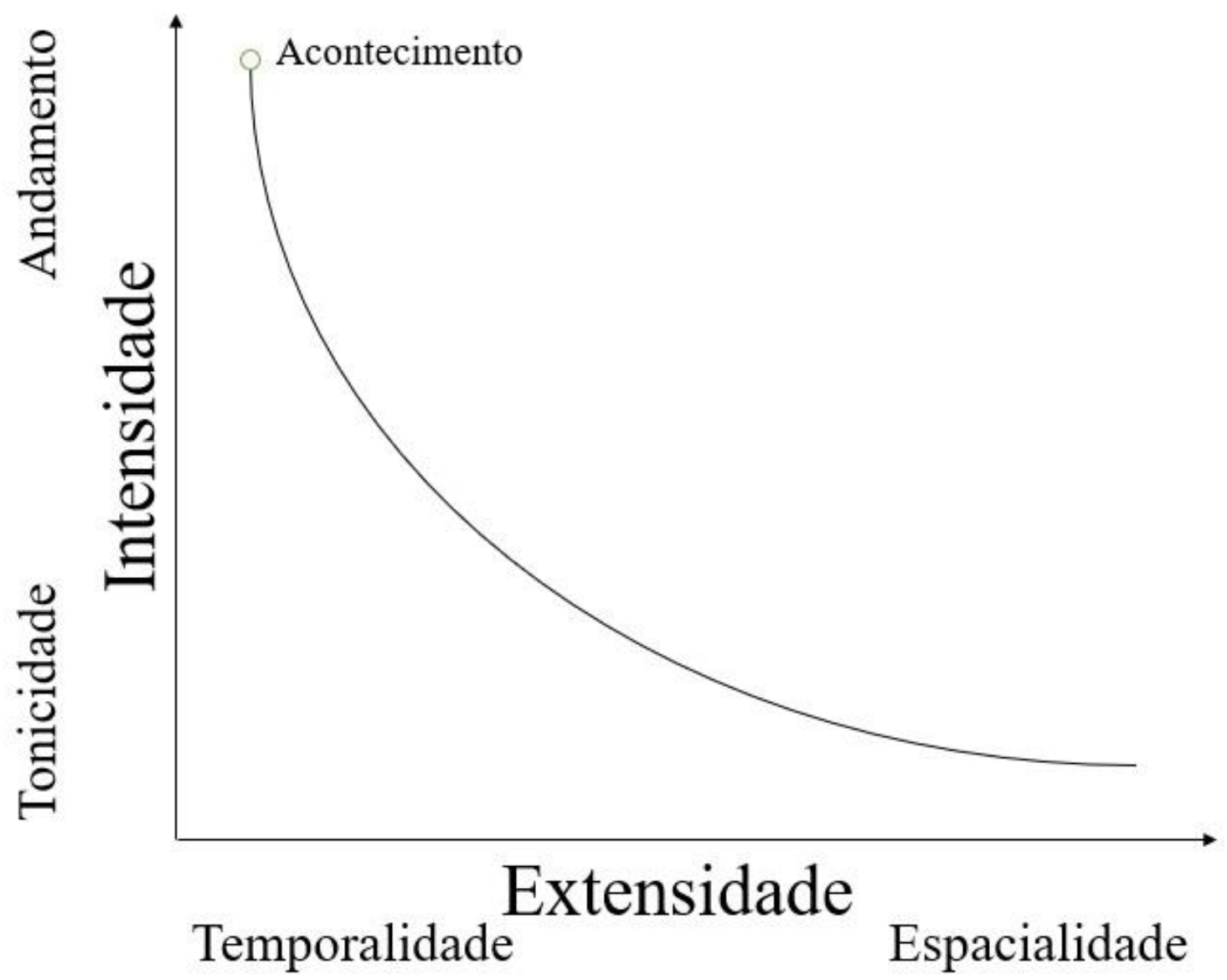

(Figura 2.9 - Cifra tensiva do acontecimento. Adaptado de ZILBERBERG (2011))

Não é só o protagonista que precisa digerir a informação, mas também é o jogador que o encarna que precisa de um momento para lidar com o choque e a crueldade inesperada.

Ainda apoiados em Zilberberg, temos: "Marcado por um andamento rápido demais para o sujeito, o acontecimento leva o sensível à incandescência e o inteligível à nulidade" (Idem, p. 190). A partir da visão traumática da meretriz pregada, Geralt passa 
a se situar em um percurso passional de cólera, desejando a vingança contra o Filho da Puta Júnior por um possível mal que ele tenha causado à sua pupila. Isso é claramente representado pela própria interface do jogo. Quando o sujeito chega até a mulher pregada, o objetivo da missão muda, exibindo a frase "Mate o Filho da Puta Júnior" (ver Figura 2.8), demonstrando que o sensível tomou conta do inteligível do sujeito.

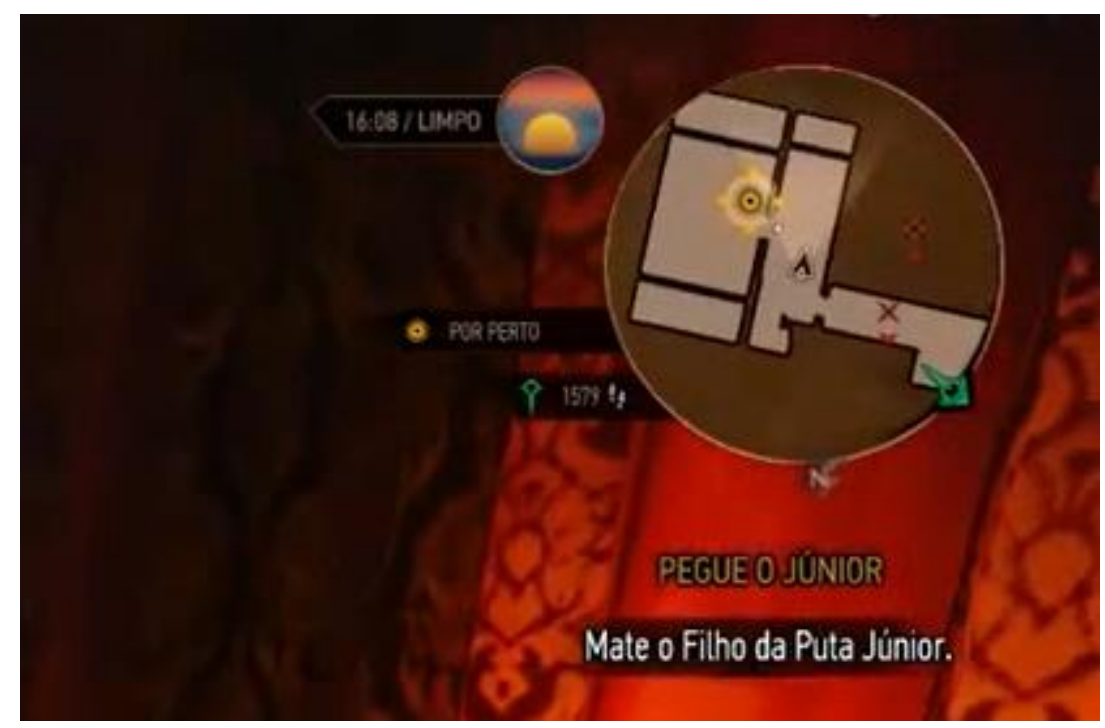

(Figura 2.10 - Zoom da Figura 2.8. A mensagem "Mate o Filho da Puta Júnior" indica qual é o próximo passo para o jogador concluir a missão.)

Em "Sobre a cólera", Greimas nos apresenta o que seria um pequeno percurso que leva à cólera:

“frustração" $\rightarrow$ “descontentamento" $\rightarrow$ "agressividade” (GREIMAS, 2014, p. 234)

Se aplicarmos o programa narrativo de Geralt buscando informações sobre Ciri com Willy, podemos dizer que o sujeito espera receber essas informações, já que Willy foi o último que teve contato com a garota em Novigrad. No entanto, ao notar que o chefão deseja a sua morte, Geralt não só aumenta a sua sensação de falta objetal (paradeiro da filha), como também nota uma falta fiduciária (não pode confiar totalmente em um homem que quer matá-lo), causando-lhe o descontentamento. O acontecimento 
disfórico que expusemos acima serve como um acréscimo passional ainda maior para esse programa narrativo colérico, de modo que o sujeito passa a buscar a vingança, já que acredita que Willy machucou Ciri.

A punição de Willy seria uma maneira de o sujeito "reequilibrar sofrimentos" (Idem, p. 249), no entanto, Geralt não pode matá-lo sem antes descobrir o que ele sabe sobre Ciri. Ainda assim, a agressividade já se manifesta antes do interrogatório (ver Figuras 2.11 à 2.16).

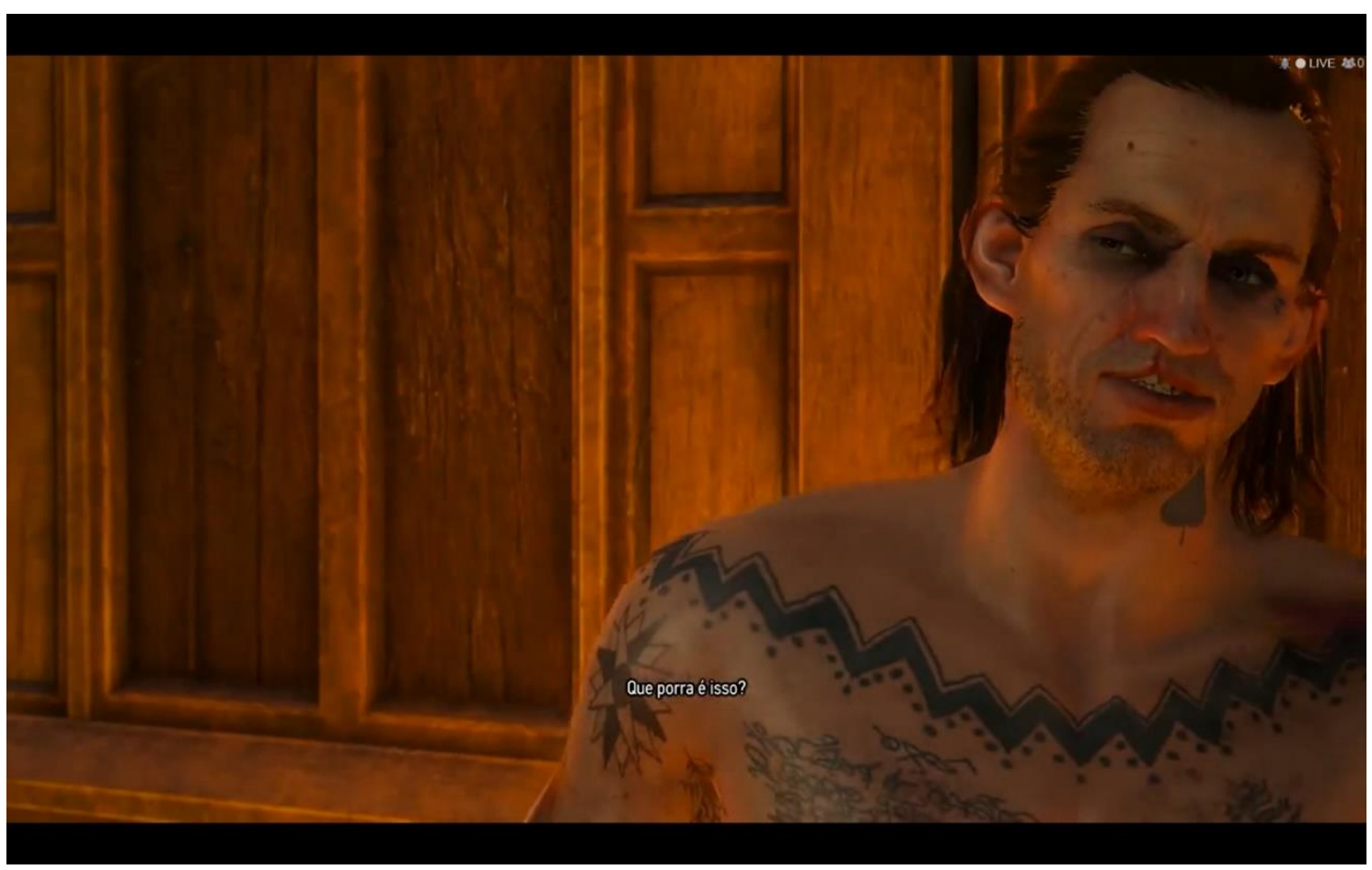

(Figura 2.11 - Júnior não entende o que está acontecendo ao ver Geralt adentrando seu quarto, indagando "Que porra é isso?") 


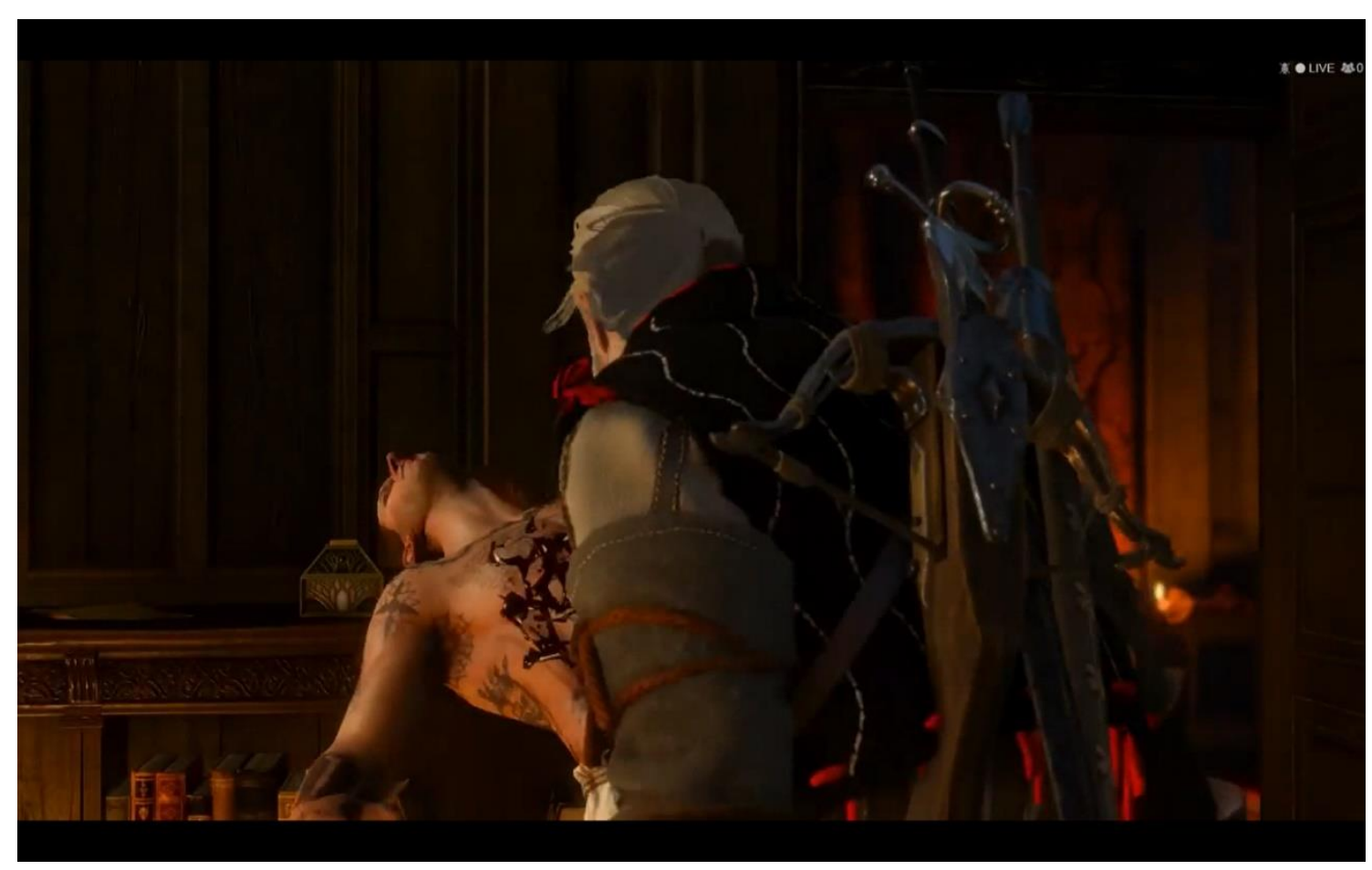

(Figura 2.12 - Sem hesitar, Geralt golpeia Willy repetidamente.)

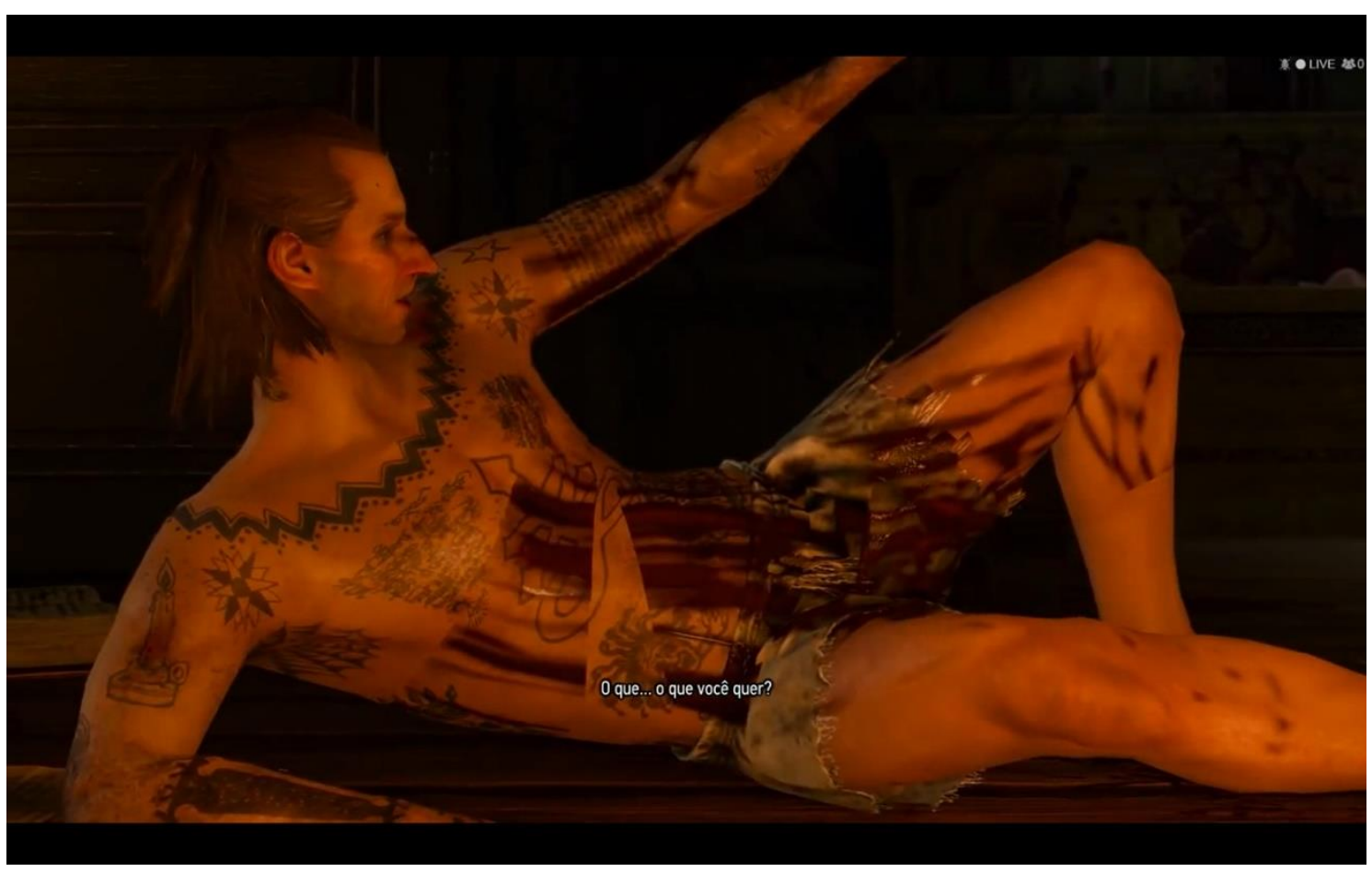

(Figura 2.13 - Depois de ser espancado, Willy ainda tenta fingir que não sabe do que se trata.) 


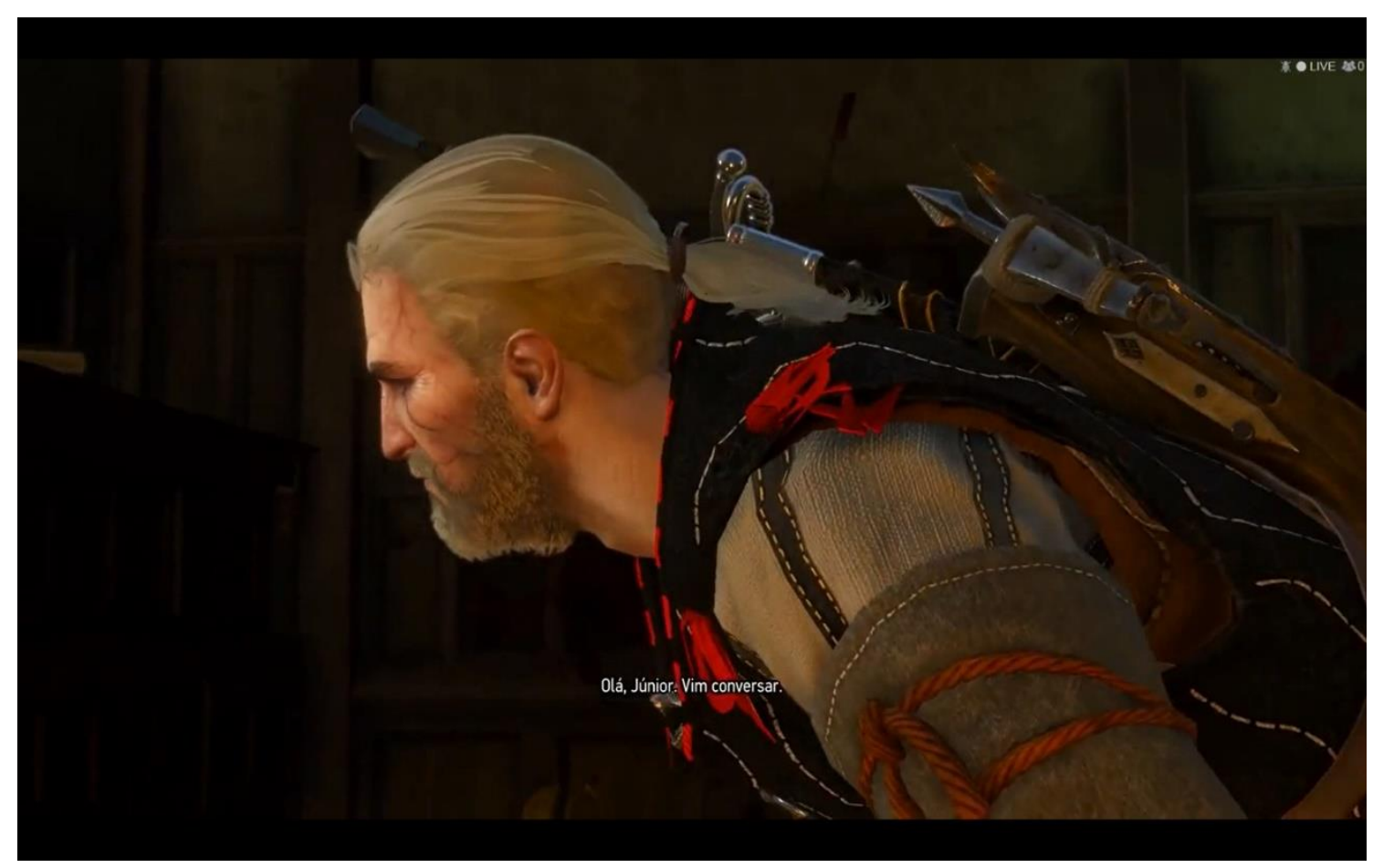

(Figura 2.14 - Geralt se inclina e diz querer conversar)

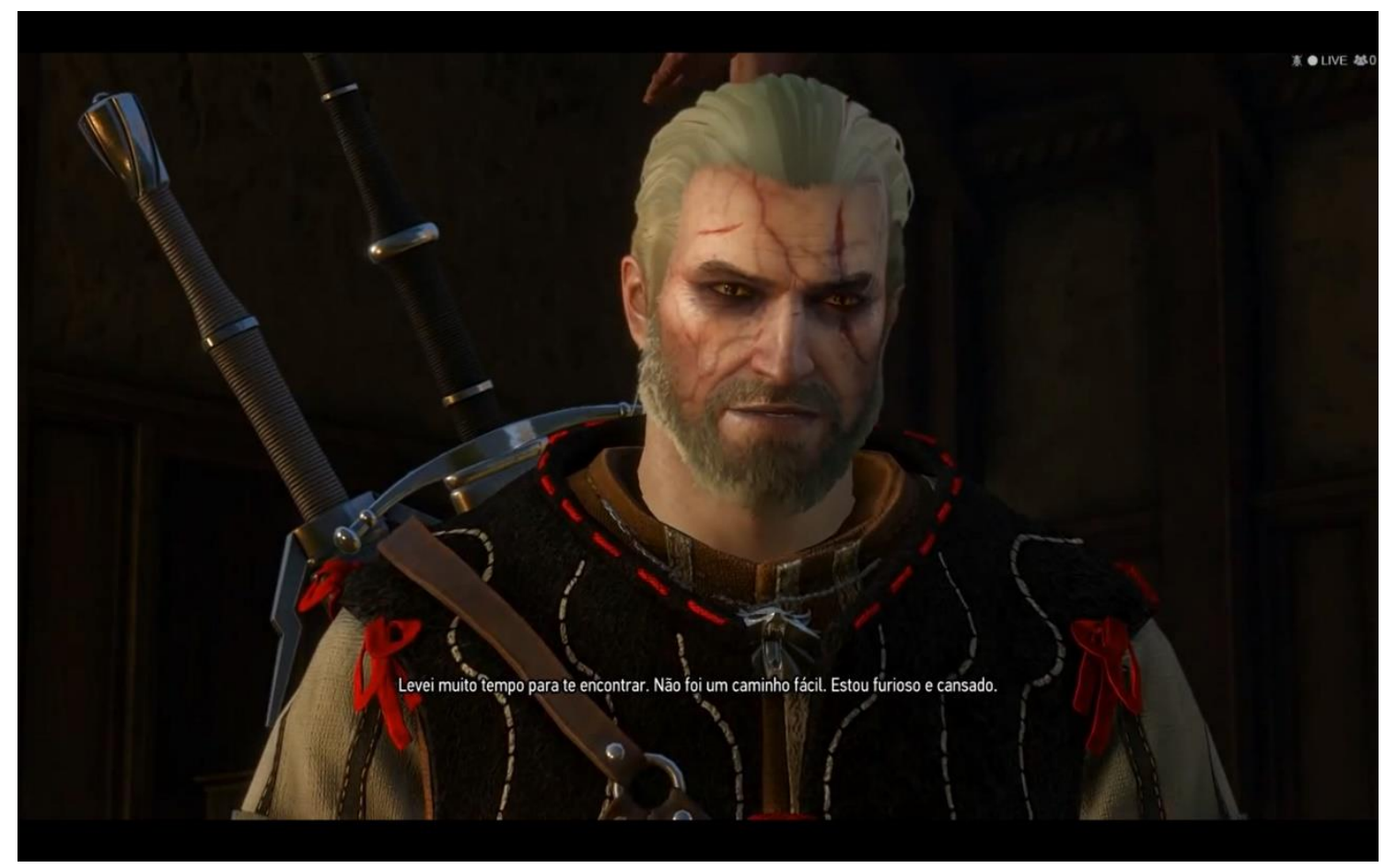

(Figura 2.15 - "Levei muito tempo para te encontrar. Não foi um caminho fácil. Estou furioso e cansado". Sujeito expressa seu descontentamento.) 


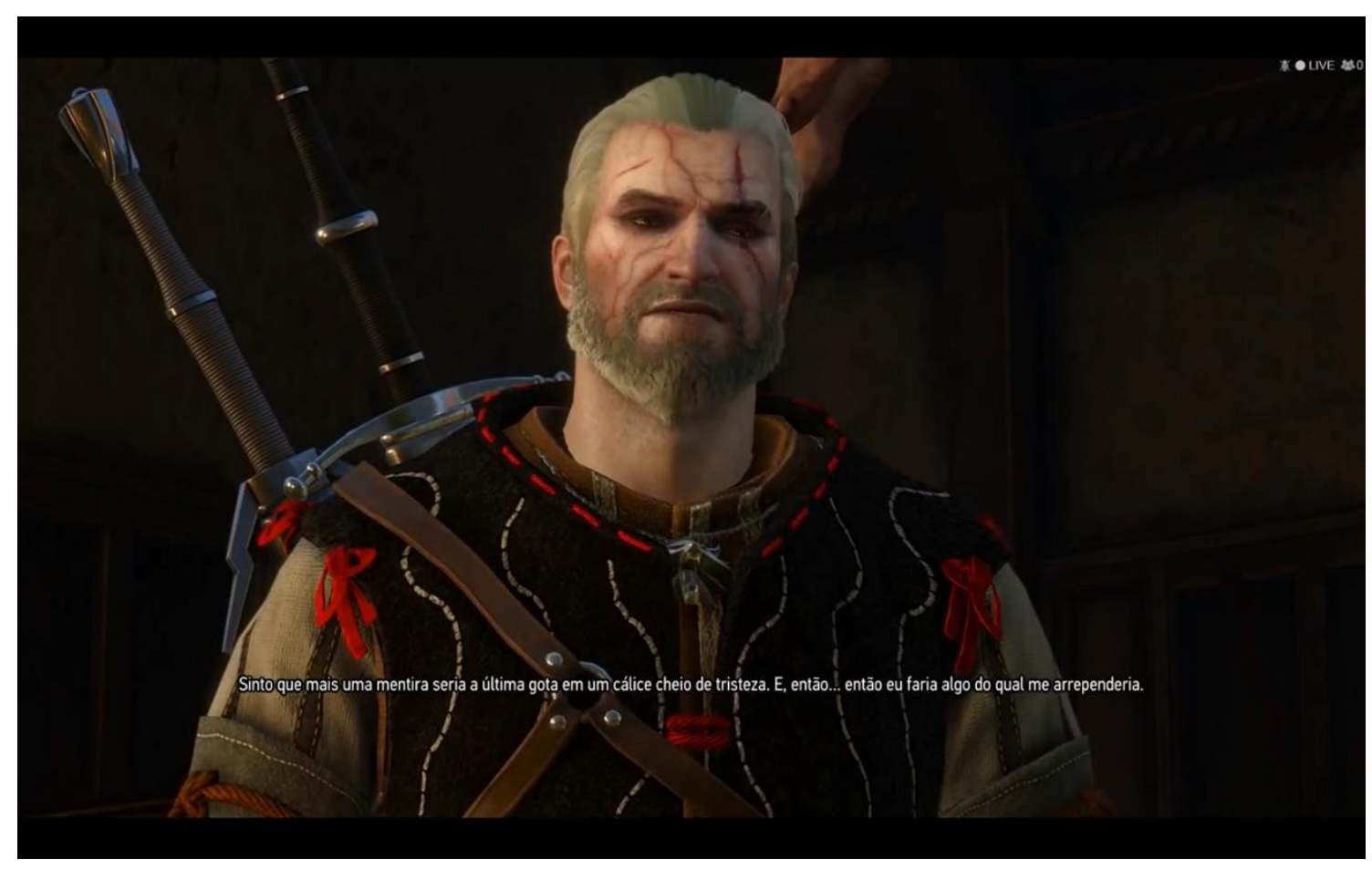

(Figura 2.16 - "Sinto que mais uma mentira seria a última gota em um cálice cheio de tristeza. E, então... então eu faria algo do qual me arrependeria." Sujeito ameaçando vingança.)

Willy diz que Ciri o procurou para que ele a orientasse em relação a um artefato mágico. O bandido pedira a ela o tesouro de Sigi Reuven, um dos outros quatro chefões do crime de Novigrad. Como maneira de garantir que a garota o traria o tesouro, Willy sequestrara Dudu, um amigo dela. O último encontro dos dois foi no momento em que Ciri bravamente enfrentou Willy e seus capangas para libertar seu amigo, de modo que ambos fugiram feridos.

Ao saber que sua filha adotiva fora ferida, Geralt conclui o percurso passional da cólera. Apoiando-nos novamente em Greimas,

o poder-fazer, exacerbado, domina inteiramente o sujeito, que passa ao fazer antes que um programa de ação esteja definitivamente elaborado, não sendo capaz de utilizar senão dos elementos esparsos capazes de fundar esse programa, reunidos sob a rubrica da agressividade orientada (afirmação de si e destruição do outro). (Idem, p. 253). 
É neste momento da narrativa que o próprio jogo deixa a decisão de Geralt nas mãos do jogador, optando por matar ou não Willy Cipriano. Em todo caso, a punição acontece.

Ao escolher pela morte, Geralt informa que não pode deixar Willy viver sabendo que ele feriu uma pessoa muito importante para ele, concluindo o percurso passional da cólera com a destruição do outro.

Caso o jogador escolha não matar Willy, Geralt informa aos outros três chefões do crime de Novigrad que Willy havia tentado uma aliança com o rei Radovid. Desse modo, ainda temos um resultado vingativo.

Deste modo, esboçamos brevemente neste capítulo o funcionamento do jogo e a questão passional envolvendo um protagonista "sem emoções", o qual constatamos majoritariamente regido pela indiferença. No capítulo seguinte, focaremos nas relações intertextuais presentes no enredo de The Witcher III: Wild Hunt. 


\section{Capítulo 3}

\section{Intertextualidade em The Witcher III: Wild Hunt}

\subsection{Intertextualidade e as mídias ${ }^{41}$}

A orientação dialógica é naturalmente um fenômeno próprio a todo o discurso. Trata-se da orientação natural de qualquer discurso vivo. Em todos os seus caminhos até o objeto, em todas as direções, o discurso se encontra com o discurso de outrem e não pode deixar de participar, com ele, de uma interação viva e tensa. Apenas o Adão mítico que chegou com a primeira palavra num mundo virgem, ainda não desacreditado, somente este Adão podia realmente evitar por completo esta mútua-orientação dialógica do discurso alheio para o objeto. Para o discurso humano, concreto e histórico, isso não é possível: só em certa medida e convencionalmente é que pode dela se afastar. (BAKHTIN, 2014, p. 88).

A citação de Bakhtin nos é útil e deveras fundamental para este capítulo. Segundo o filósofo russo, os discursos estão sempre dialogando entre si, de modo que a criação de um novo discurso sempre terá a influência de discursos de outrem. Dessa maneira, o dialogismo se instaura como princípio constitutivo da linguagem.

Os homens não têm acesso direto à realidade, pois nossa relação com ela é sempre mediada pela linguagem. (...) Isso quer dizer que o real se apresenta para nós semioticamente, o que implica que nosso discurso não se relaciona diretamente com as coisas, mas com outros discursos, que semiotizam o mundo. (FIORIN, 2016, p. 167).

Quando criamos um enunciado, nele não está só presente nossa vontade expressa por palavras, como também as influências do contexto social em que nos inserimos religião, ensino, experiência no mundo, valores aprendidos com a família e a sociedade,

\footnotetext{
${ }^{41}$ Sabemos que o termo "mídia" se refere a qualquer meio de difusão de informação em que seja possível se transmitir uma mensagem, no entanto, neste capítulo, estamos focando em meios midiáticos relacionados à cultura pop, ou seja, telemáticos, cinema, quadrinhos, videogame e desenhos animados.
} 
posicionamento político, entre outros - ou seja, na nossa voz está presente um diálogo constante, internalizado, do qual manifestamos frequentemente.

Entretanto, quando nos referenciamos aberta e diretamente a certo texto, passamos a fazer uso da intertextualidade. "Ela é o processo da relação dialógica não somente entre duas "posturas de sentido", mas também entre duas materialidades linguísticas" (Idem, p. 184).

E na intertextualidade não há fronteiras, não há linha divisória entre o eu e o outro, não há ruptura. Intertextualidade é a retomada consciente, intencional da palavra do outro, mostrada, mas não demarcada no discurso da variante. (DISCINI, 2004, p. 11).

Muitos poetas lançam mão da intertextualidade para enriquecerem os seus poemas, ou, de maneira oposta, para parodiar e gerar o humor a partir do diálogo entre a sua criação e o texto original. Tomemos como exemplo a relação intertextual entre "Canção do exílio" e "Jogos florais":

\section{Canção do exílio}

Minha terra tem palmeiras,

Onde canta o Sabiá;

As aves, que aqui gorjeiam,

Não gorjeiam como lá.

Nossos céus têm mais estrelas,

Nossas várzeas têm mais flores,

Nossos bosques têm mais vida,

Nossa vida mais amores.

Em cismar, sozinho, à noite,

Mais prazer eu encontro lá;

Minha terra tem palmeiras, 
Onde canta o Sabiá.

Minha terra tem primores,

Que tais, não encontrou eu cá;

Em cismar, sozinho, à noite,

Mais prazer eu encontro lá;

Minha terra tem palmeiras,

Onde canta o Sabiá.

Não permita Deus que eu morra,

Sem que eu volte para lá;

Sem que disfrute os primores,

Que não encontro por cá;

Sem qu'inda aviste as palmeiras,

Onde canta o Sabiá.

(Gonçalves Dias) $^{42}$

\section{Jogos florais}

Minha terra tem palmeiras

onde canta o tico-tico.

Enquanto isso o sabiá

vive comendo o meu fubá.

Ficou moderno o Brasil

ficou moderno o milagre:

a água já não vira vinho

vira direto vinagre.

Minha terra tem Palmares

memória cala-te já.

Peço licença poética

Belém capital Pará

\footnotetext{
${ }^{42}$ Retirado de http://www.horizonte.unam.mx/brasil/gdias.html. Acesso em 21/01/2020.
} 


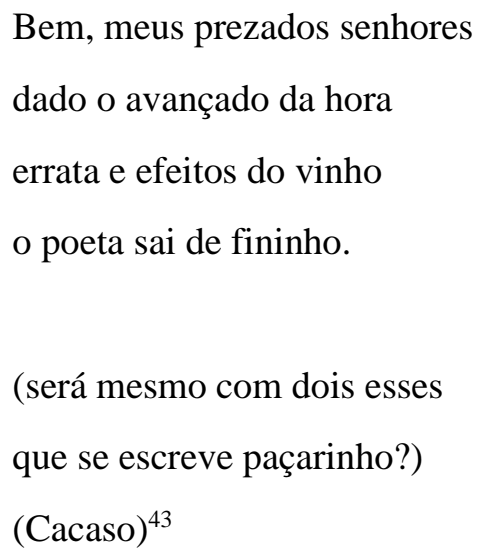

Como podemos notar, o poema de Cacaso demonstra uma clara relação de intertextualidade com o de Gonçalves Dias. Em sua obra, Cacaso, poeta marginal do Brasil ditatorial, alude ao poema marcante do Romantismo brasileiro, no entanto, o desconstrói para causar o efeito de humor e de crítica. "Canção do exílio" é um grande elogio à pátria, o que serviria de exemplo nacionalista para a ditadura vigente no Brasil no período. A paródia de Cacaso não é exatamente uma desconstrução de Gonçalves Dias, mas verdadeira voz de crítica ao governo militar. Através da relação dialógica, Cacaso alude à figura libertária de Zumbi (Minha terra tem Palmares), ao mesmo tempo que denuncia a opressão e violência da ditadura militar (a água já não vira vinho / vira direto vinagre, memória cala-te já), critica o ensino formal (Belém capital Pará) e ainda põe em xeque a figura de Jarbas Passarinho, ministro da Educação durante o governo Médici e também signatário do AI-5. ${ }^{44}$

A intertextualidade manifesta não é um recurso exclusivo do ambiente literário ou acadêmico, mas também tem se feito presente nas produções artísticas mais recentes e nas mídias, inclusive em produtos da cultura pop contemporânea. Filmes blockbusters, animes, quadrinhos e narrativas de jogos eletrônicos têm criado suas relações intertextuais entre si, ou mesmo, com textos considerados do cânone literário.

No filme de super-heróis Vingadores: Era de Ultron (Joss Whedon, 2015), os famosos heróis da Marvel, unidos para impedir a seita H.Y.D.R.A de avançar com suas vilanias, recuperam o cetro de Loki (Tom Hiddleston). Tentando defender a Terra de futuras invasões alienígenas, Tony Stark (Robert Downey Jr.) cria o projeto Ultron, uma

\footnotetext{
${ }^{43}$ Retirado de http://culturafm.cmais.com.br/radiometropolis/lavra/cacaso-jogos-florais. Acesso em 21/01/2020.

${ }^{44}$ https://pt.wikipedia.org/wiki/Jarbas_Passarinho. Acesso em 21/01/2020.
} 
Inteligência Artificial que blindaria todo o planeta. No entanto, Ultron se volta contra seu criador e decide que a única maneira de o planeta obter paz é através da extinção da raça humana. Em meio aos conflitos, Tony Stark e o doutor Bruce Banner (Mark Ruffalo) se apossam de um androide meio humano, meio máquina. Discutindo uma possível forma de combater Ultron, os dois cientistas decidem utilizar o androide recém-obtido contra seus inimigos. Discordando das intenções dos aliados, Capitão América (Chris Evans) e outros tentam impedir a inicialização do androide. Dá-se início a uma briga interna entre os Vingadores que só é pausada com a ação de Thor (Chris Hemsworth) que aplica uma descarga elétrica sobre o androide (ver Figura 3.1).

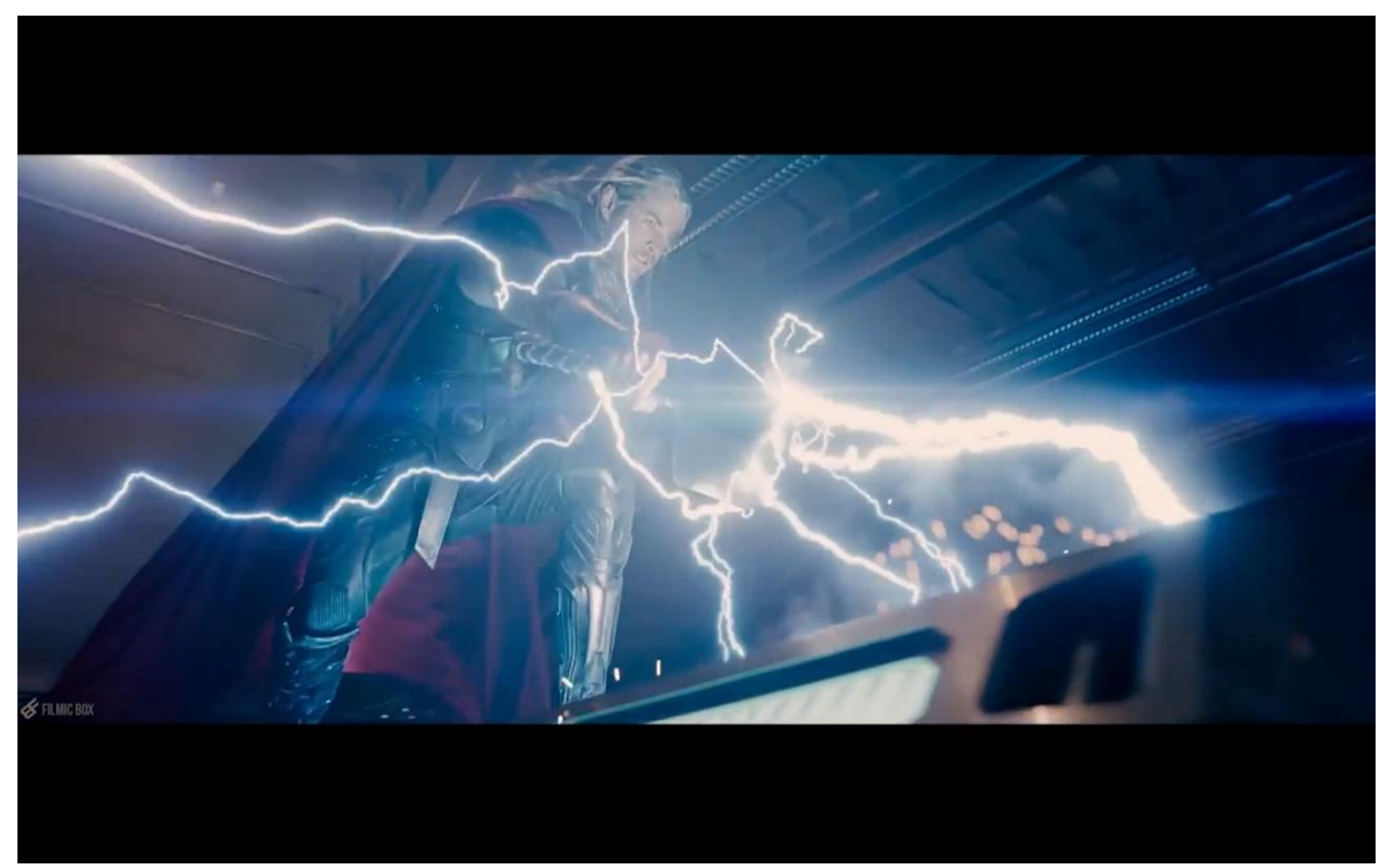

(Figura 3.1 - Thor direciona a eletricidade conduzida por seu martelo à cúpula em que o androide meio humano está.)

Todos os outros heróis ficam sem reação. Após a carga elétrica sobre a cúpula, esta estoura e a figura meio humana, meio máquina, ergue-se na presença de seus criadores (ver Figura 3.2 e 3.3). 


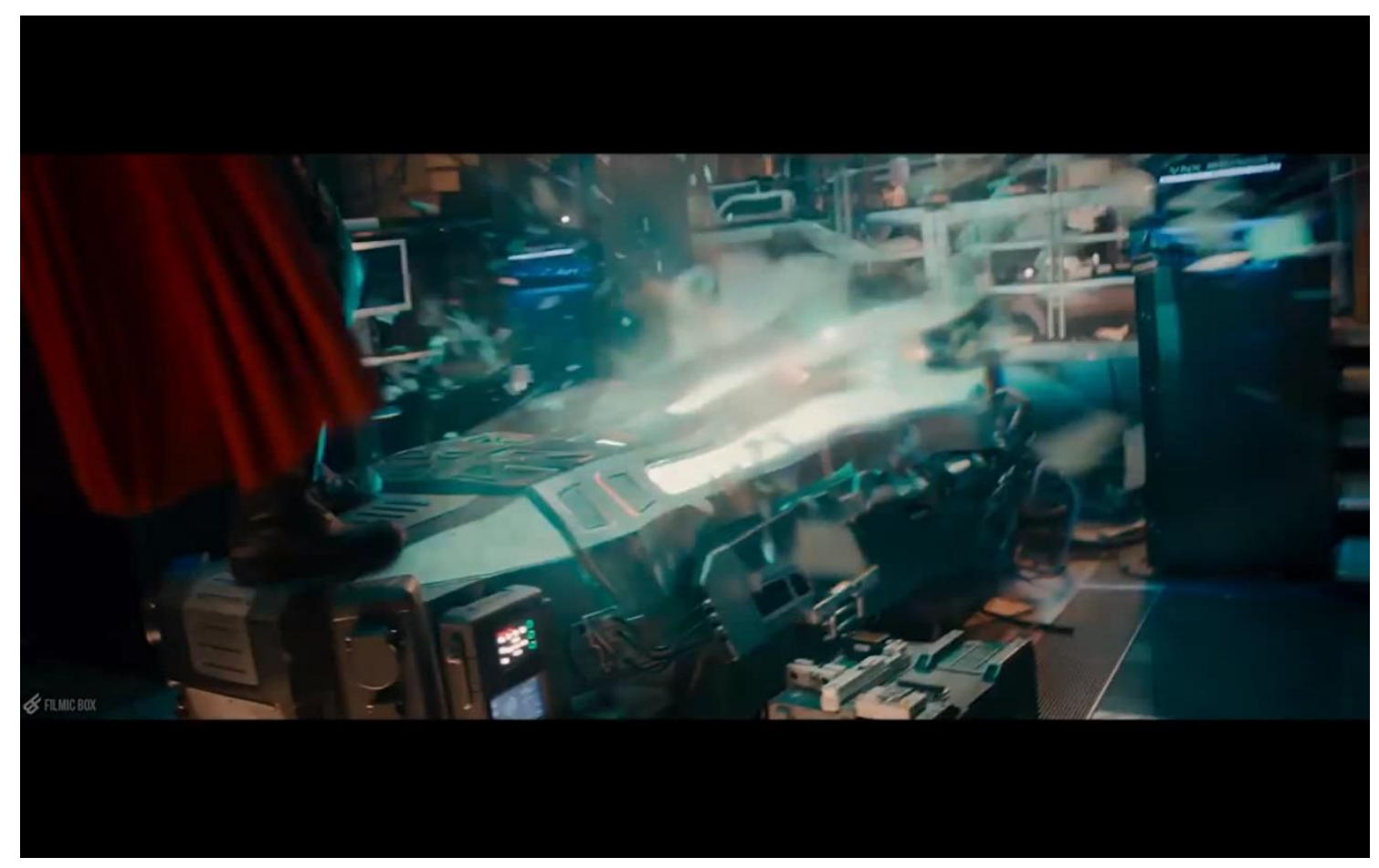

(Figura 3.2 - O compartimento explode.)

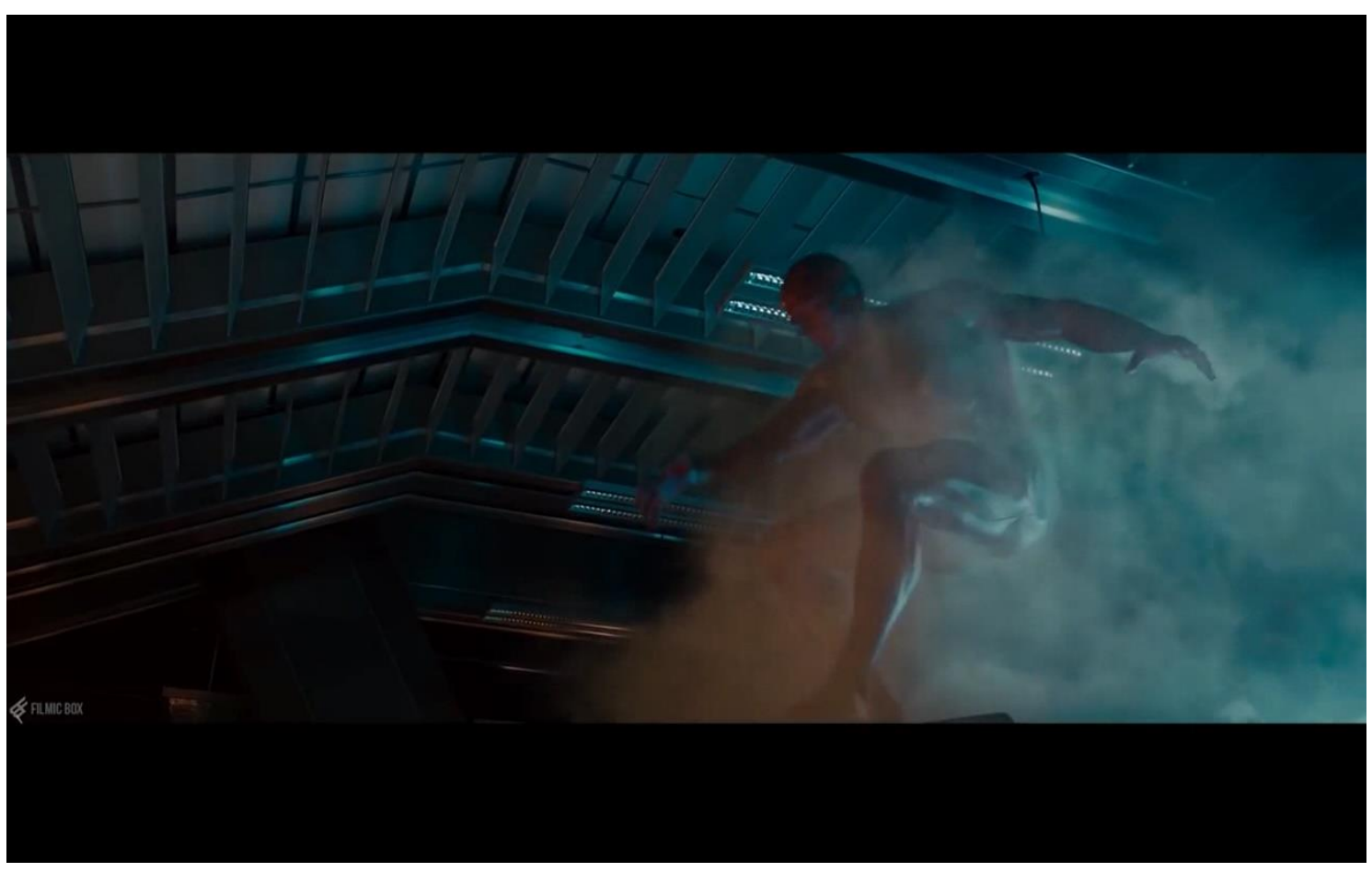

(Figura 3.3 - O homem-máquina se levanta de seu leito.)

A cena é criada artisticamente desse modo, em um diálogo com a narrativa de Frankenstein, de Mary Shelley. 
Foi numa sombria noite de novembro que contemplei a consumação de minha obra. Com uma ansiedade que beirava a agonia, reuni os instrumentos ao meu redor, de modo que pudesse infundir uma centelha de vida na coisa inanimada que jazia aos meus pés. Já era uma hora da manhã; a chuva tamborilava tristemente contra as vidraças, e minha vela estava quase consumida quando, ao brilho fraco da luz já quase extinta, vi o olho amarelo e embaçado da criatura se abrir; ela respirou com dificuldade, e um movimento convulsivo agitou seus membros. (SHELLEY, 2016, p. 83, grifos nossos).

Em Death Note (2006), anime que adaptou as páginas do mangá de Tsugumi Ohba, narra-se a história de Light Yagami, um rapaz que encontra um caderno perdido na Terra, vindo do mundo dos shinigami, criaturas responsáveis por ditar o dia e a forma como os humanos morrem. Segundo a mitologia da história, escrevendo-se o nome de alguém e pensando no rosto da pessoa, esta morre em instantes. Ao descobrir isso, Light decide usar do poder macabro do caderno para matar incontáveis criminosos do Japão e posteriormente de outros lugares. A quantidade de mortes sincronizadas chama a atenção do povo, que passa a apelidar essa entidade assassina desconhecida de "Kira", uma variação da pronúncia da palavra killer. O egocentrismo de Light e os planos de se tornar o deus do mundo acabam sendo empecilhados por L, um rapaz que não se identifica em nenhum momento da história, mas é considerado uma das mentes mais brilhantes do Japão.

Com o desenrolar da narrativa, $L$ vai identificando padrões nos movimentos de Kira e passa a associar a figura do assassino fantasma a Light Yagami. Com intento de demonstrar sua inocência e, ao mesmo tempo, descobrir a identidade de L para escrever seu nome no caderno dos shinigami, Light decide entrar para o grupo de detetives que busca parar Kira, liderado por L.

A narrativa segue sempre cheia de suspense, até que, em dado momento, $\mathrm{L}$ tem certeza de que Kira e Light são a mesma pessoa, no entanto, para provar isso, o detetive precisa se sacrificar e deixar o compêndio de suas investigações a um sucessor que poderá ligar os pontos no futuro.

Ciente da sua morte iminente, em um dia de chuva, L e Light se encontram no terraço de um edifício e o detetive acusa o rapaz de ser um mentiroso. Light usa de suas habilidades retóricas para sair da situação e ambos deixam o ambiente chuvoso e retornam 
às escadarias do prédio. Ensopados, os dois param para descansar e L se dispõe a ajudar Light a se secar, enxugando seus pés (ver Figura 3.4).

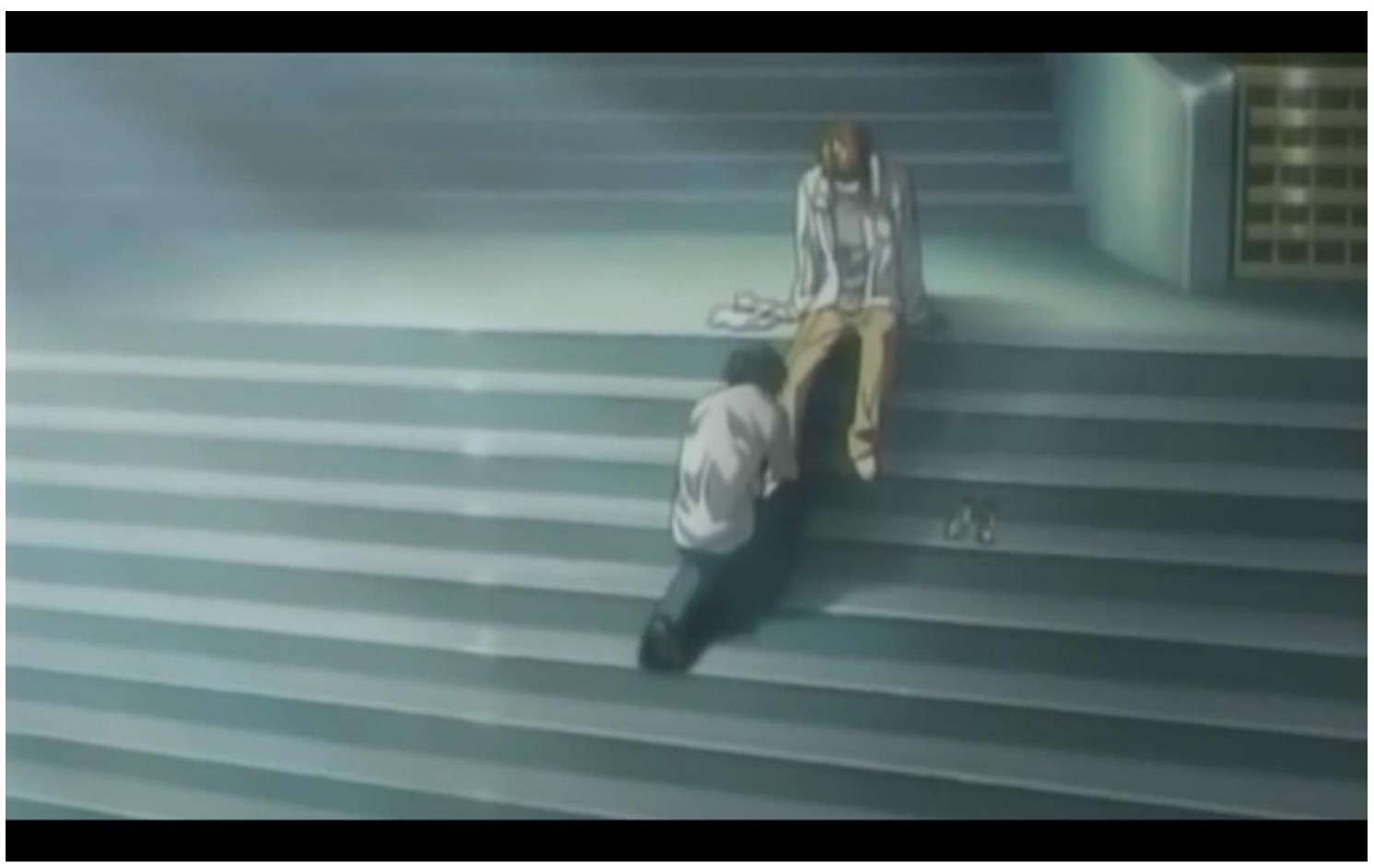

(Figura 3.4 - L (abaixo) enxuga os pés de Light.)

Após o episódio, Light consegue obter a identidade verdadeira de L e escreve seu nome no caderno, executando-o. A curiosa relação de intertextualidade se dá com a cena bíblica de Jesus Cristo lavando os pés de seus discípulos. Ambos L e Jesus sabem que após o ocorrido, irão morrer. L enxuga os pés de seu aprendiz, sabendo que ele irá matálo em um futuro próximo, assim como Jesus lava os pés de todos os discípulos, ciente de que um deles, Judas Iscariotes, irá traí-lo em breve.

Ora, antes da festa da páscoa, sabendo Jesus que já era chegada a sua hora de passar deste mundo para o Pai, como havia amado os seus, que estavam no mundo, amou-os até ao fim.

E, acabada a ceia, tendo já o diabo posto no coração de Judas Iscariotes, filho de Simão, que o traísse,

Jesus, sabendo que o pai tinha depositado nas suas mãos todas as coisas, e que havia saído de Deus e ia para Deus, 
Levantou-se da ceia, tirou os vestidos, e, tomando uma toalha, cingiu-se.

Depois deitou água numa bacia, e começou a lavar os pés aos discípulos, e a enxugarlhos com a toalha com que estava cingido.

(...)

Disse-lhe Jesus: Aquele que está lavado não necessita de lavar senão os pés, pois no mais todo está limpo. Ora vós estais limpos, mas não todos.

Porque bem sabia ele quem o havia de trair; por isso disse: Nem todos estais limpos. (João, 13:1-12, grifos nossos). ${ }^{45}$

O recurso de intertextualidade também está presente nos jogos de videogame. Lançando mão de um exemplo contemporâneo, temos Red Dead Redemption II (Rockstar Games, 2018). O jogo proporciona ao jogador a sensação de vivenciar os eventos de um clássico filme de faroeste. Na narrativa, Arthur Morgan e seus parceiros fora-da-lei estão em constante fuga da agência de investigação Pinkerton. O modo de vida livre e inconstante dos pistoleiros está dando lugar às cidades modernas e industriais, o que obriga o grupo do protagonista a se manter em um nomadismo frequente.

Em dado momento da história, o bando acampa próximo a Rhodes, uma cidadezinha controlada por duas famílias latifundiárias, os Gray e os Braithwaite, em conflito constante. Procurando explorar a inimizade entre os poderosos do local, voltando o conflito a seu favor, o líder do bando manda Arthur investigar a história das duas famílias mais a fundo. É então na missão “A rota do verdadeiro amor” que o protagonista conhece Beau Gray, um jovem sensível que é apaixonado por Penelope Braithwaite, uma garota que luta pelos direitos de igualdade entre homens e mulheres. O jovem Beau relata a Arthur que o seu amor é proibido pela sua família e manda o caubói entregar uma carta de amor secretamente a Penelope.

Ao entregar a carta, a moça diz ao protagonista que o amor entre ela e Beau poderia custar a vida dos dois, já que a rivalidade entre as famílias é mortal.

\footnotetext{
45 Trabalhamos com a versão traduzida por João Ferreira de Almeida.
} 


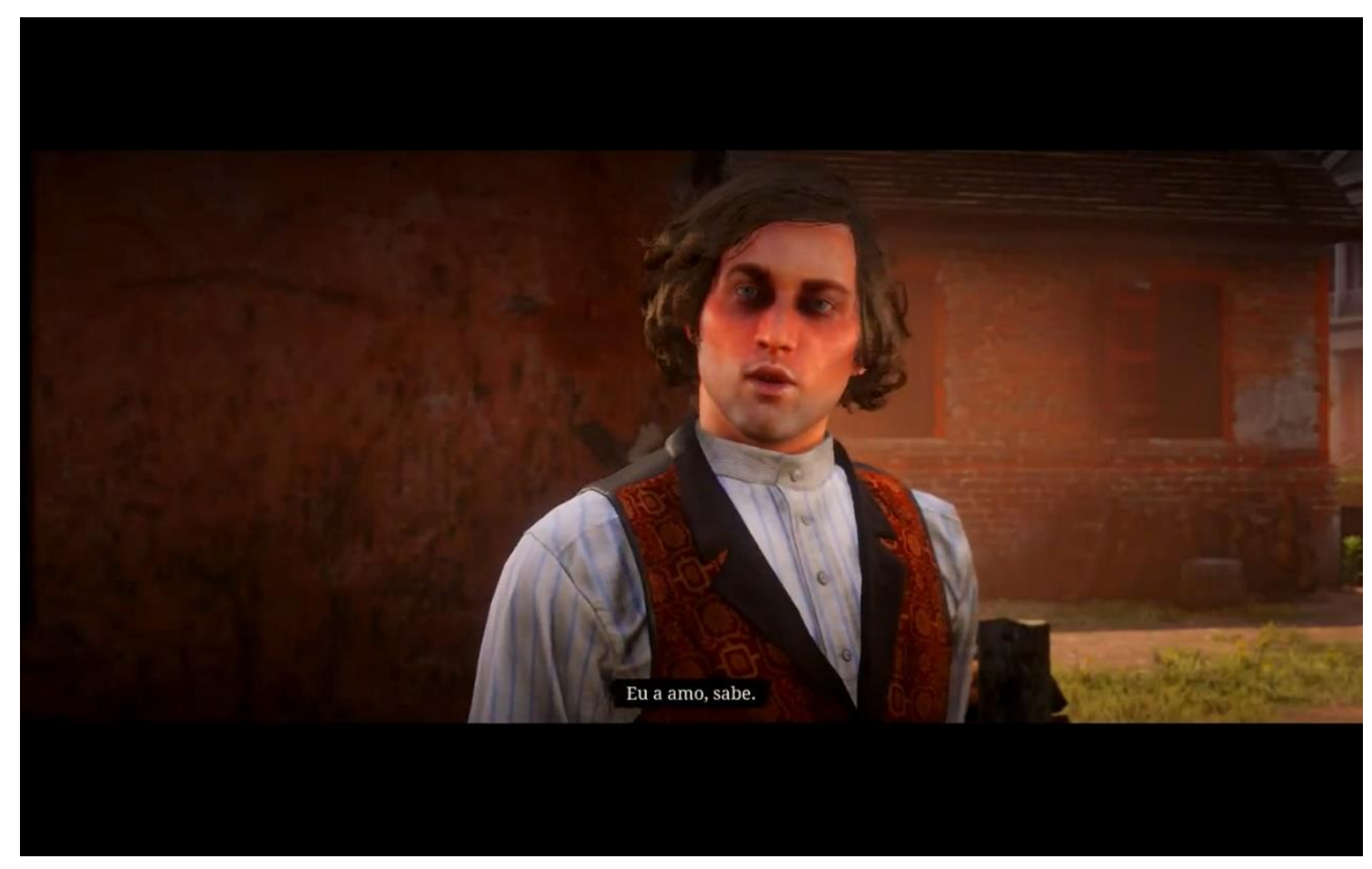

(Figura 3.5 - Beau Gray explica a situação para Arthur. "Eu a amo, sabe" diz.)

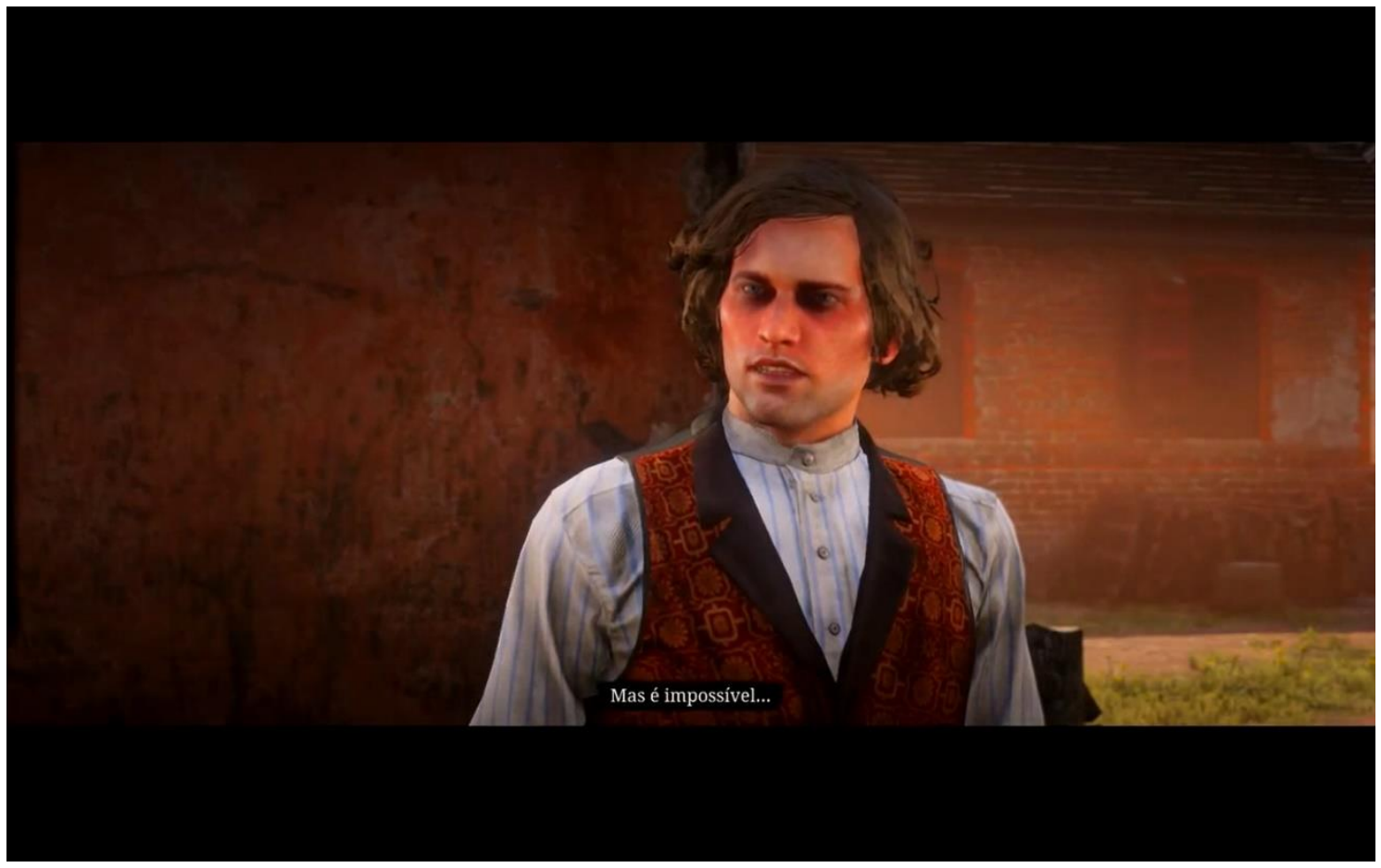

(Figura 3.6 - "Mas é impossível...") 


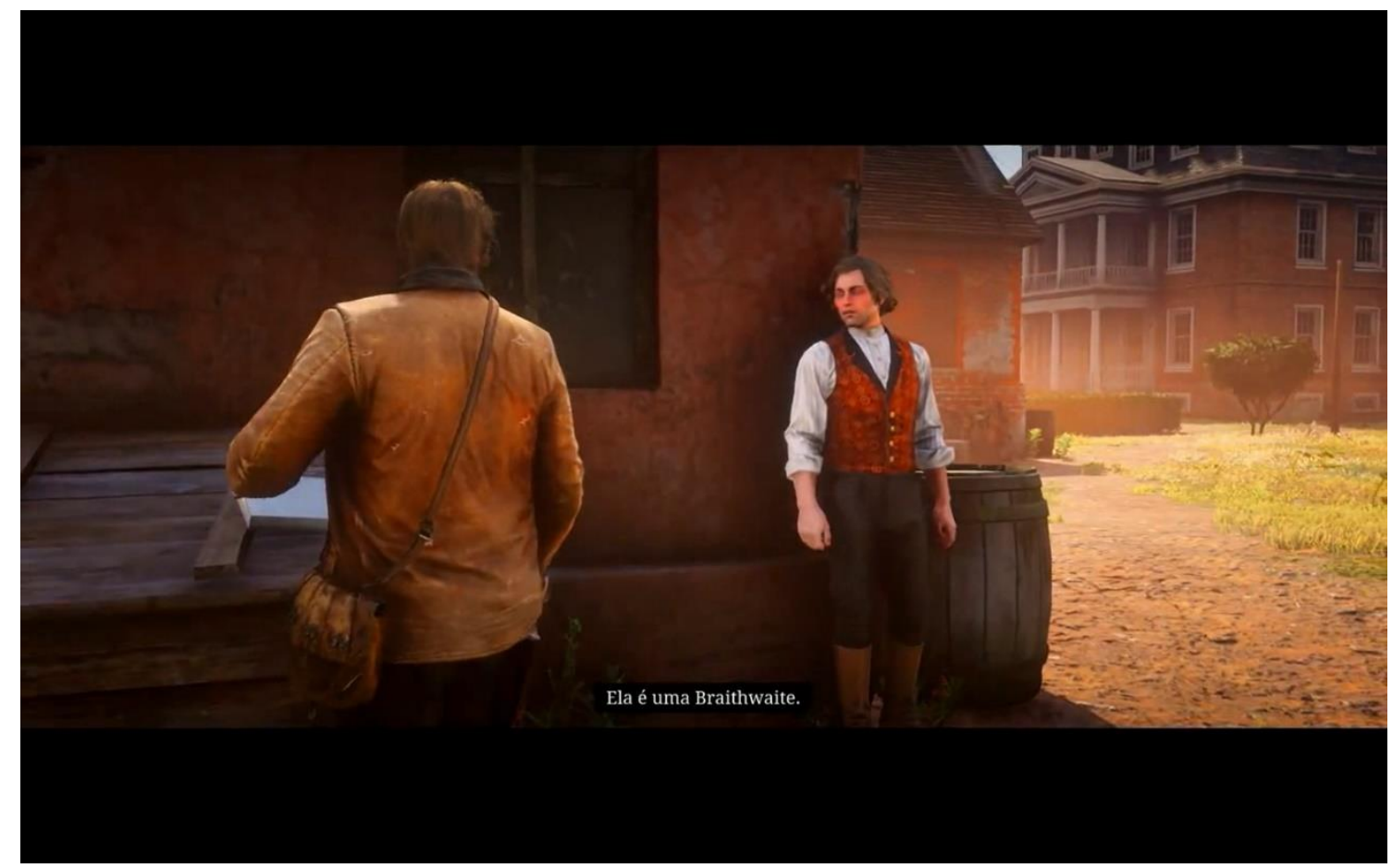

(Figura 3.7 - "Ela é uma Braithwaite")

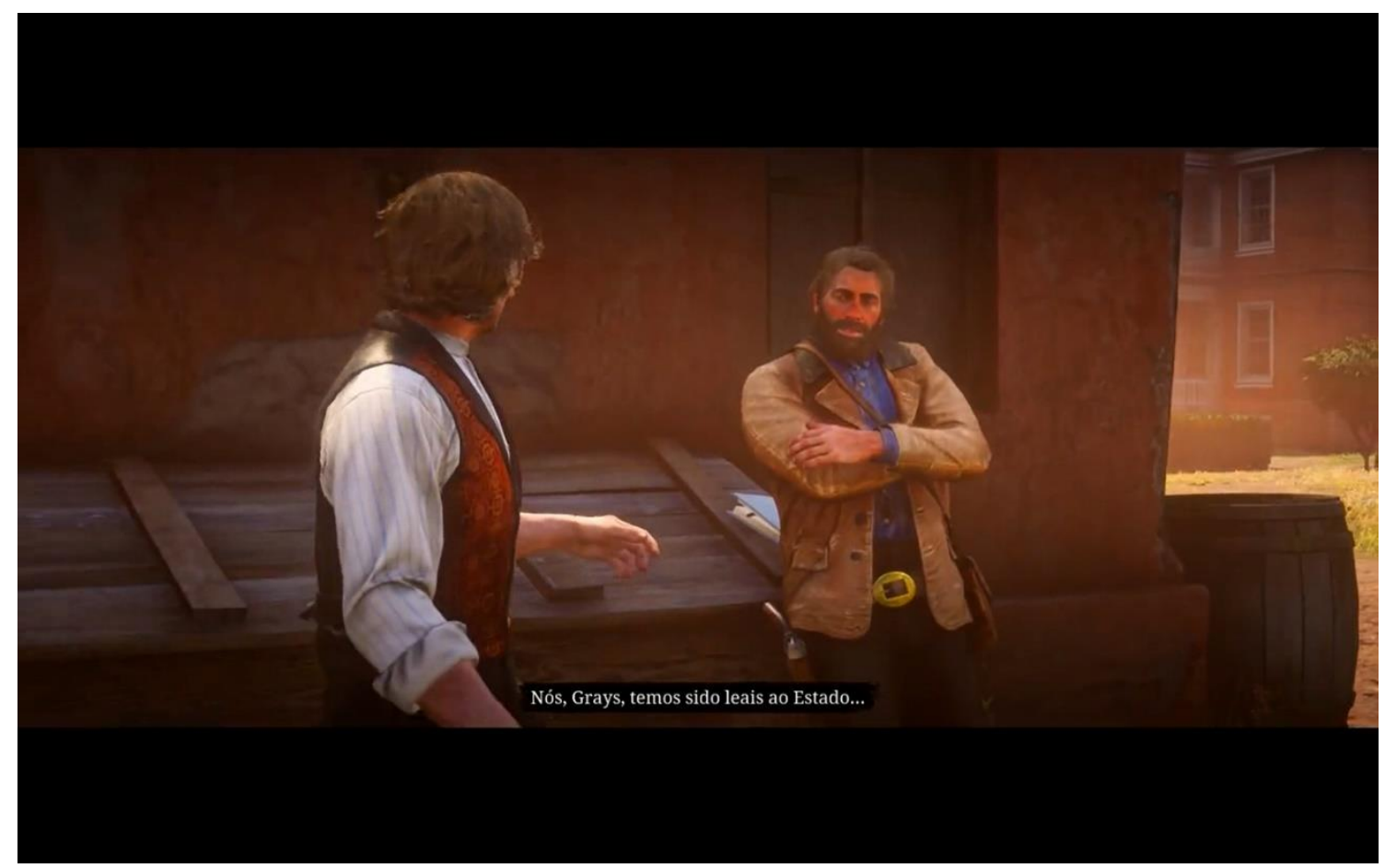

(Figura 3.8 - "Nós, Grays, temos sido leais ao Estado...") 


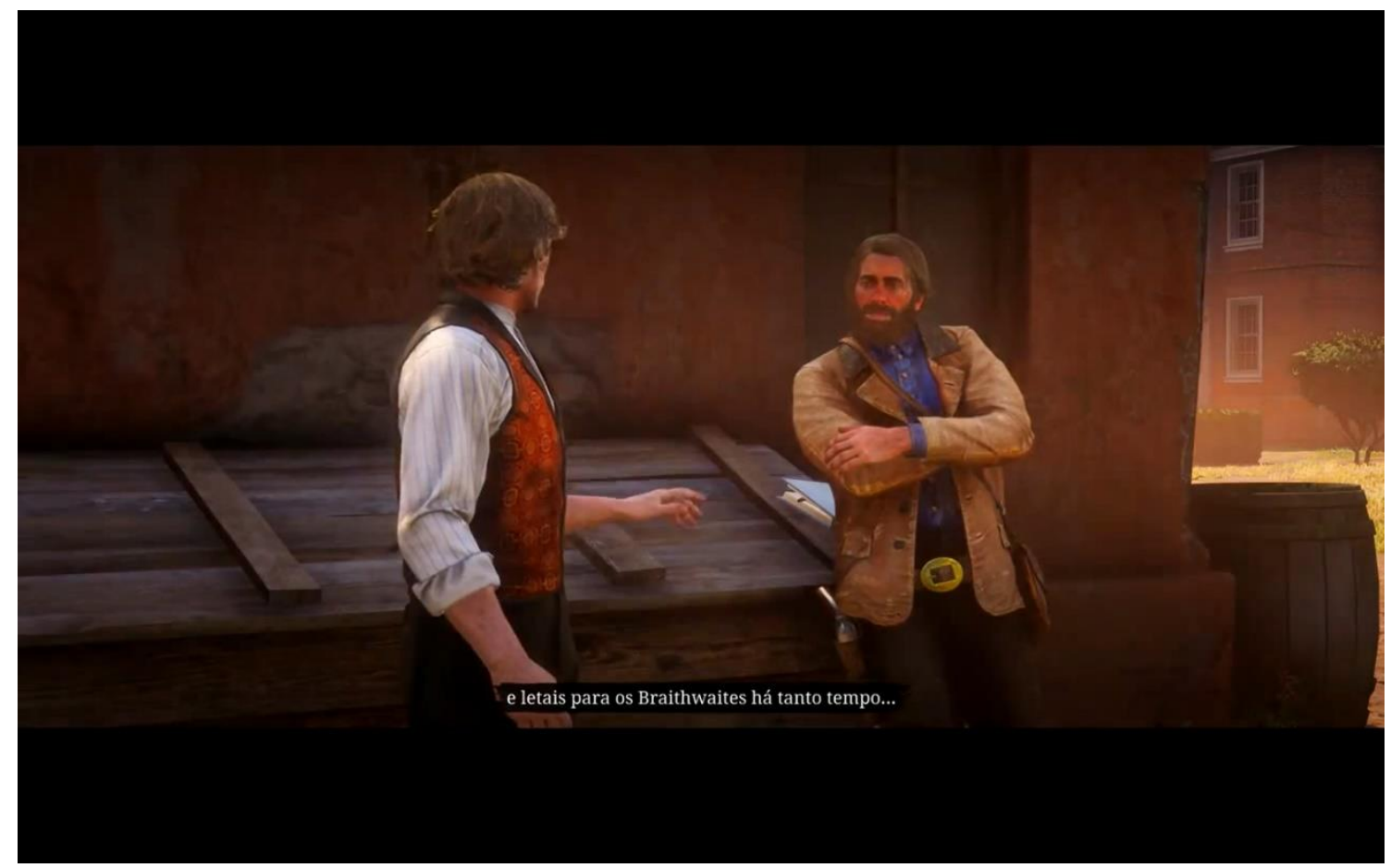

(Figura 3.9 - "e letais para os Braithwaite há tanto tempo...")

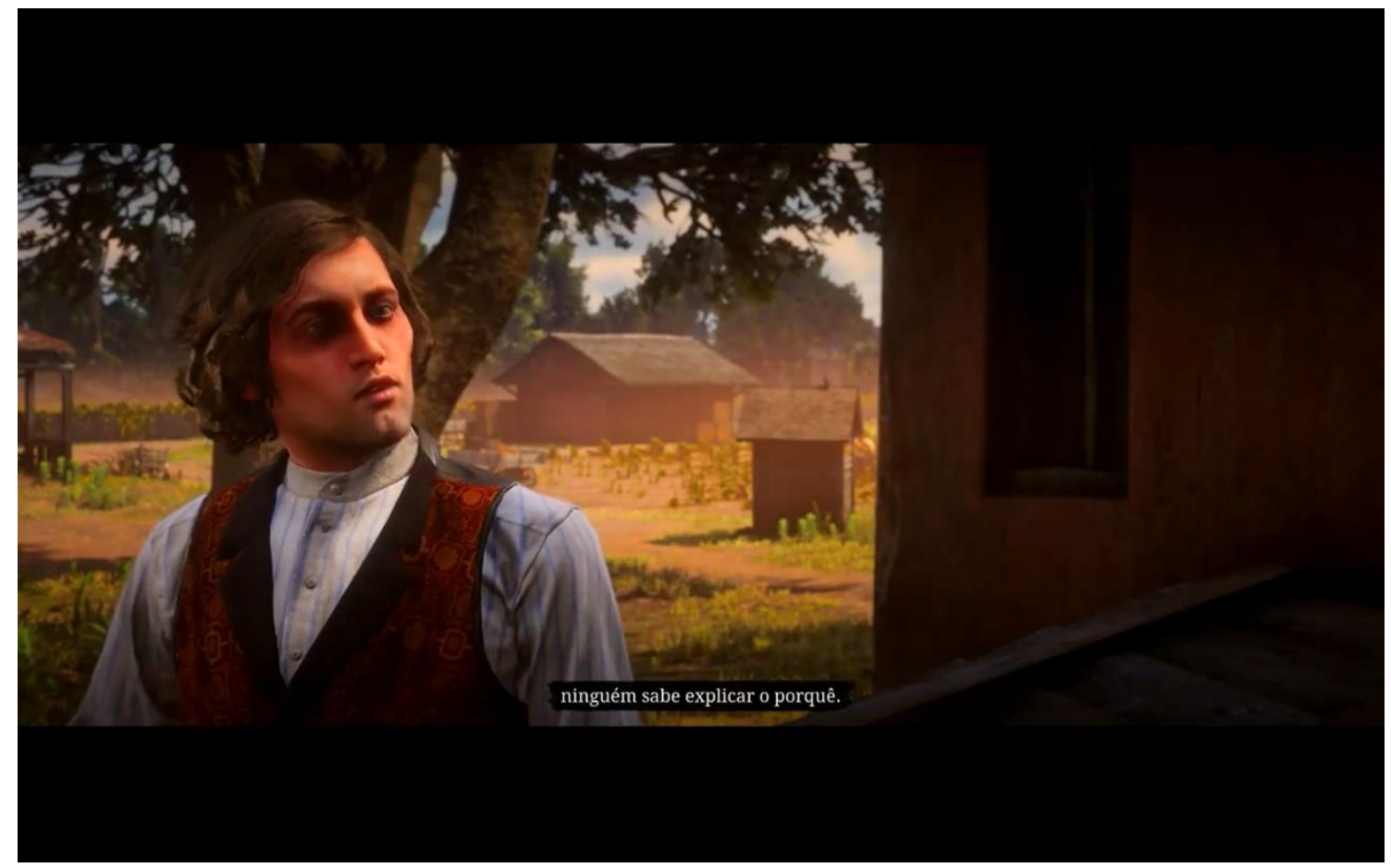

(Figura 3.10 - "ninguém sabe explicar o porquê.") 


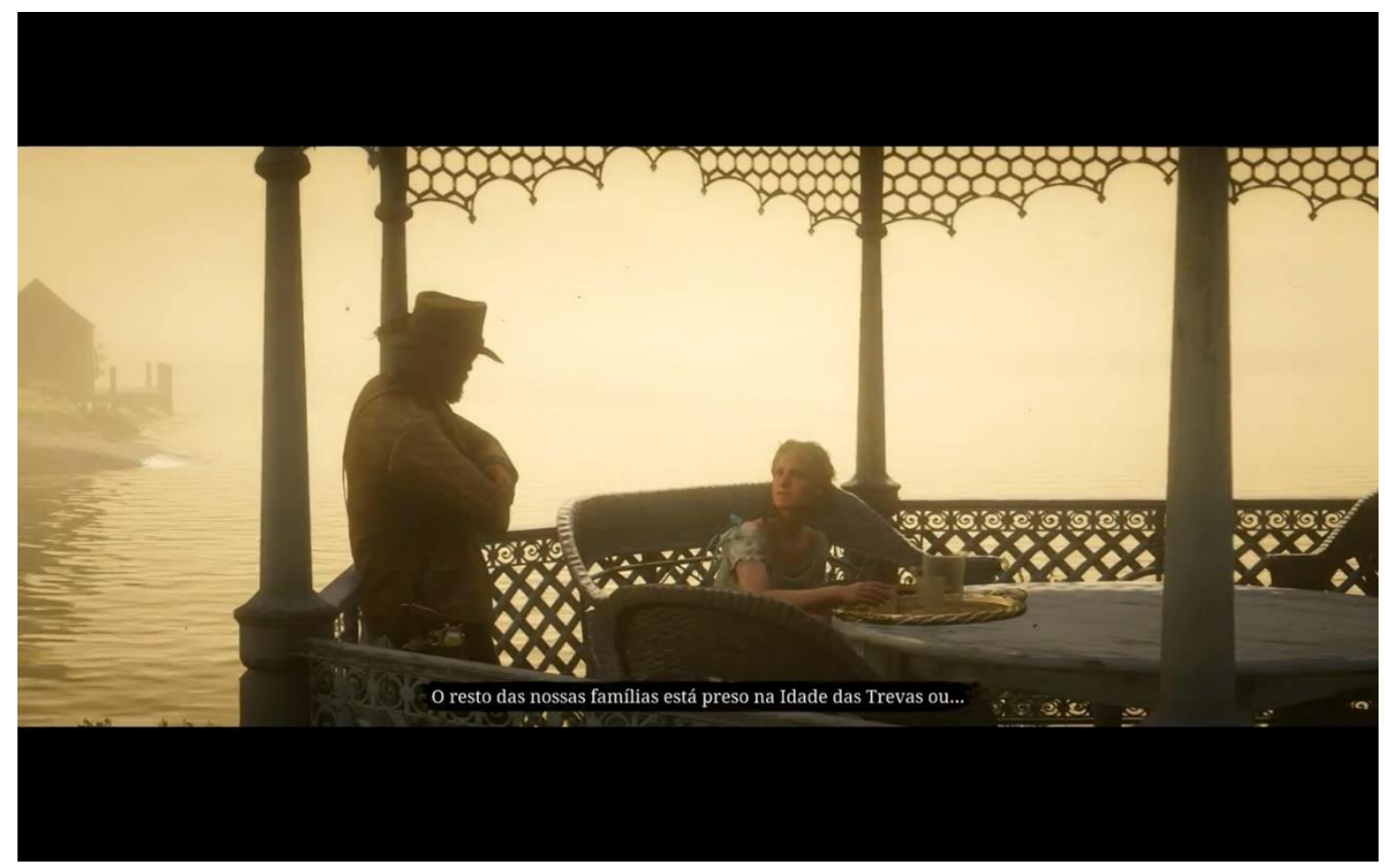

(Figura 3.11 - Arthur entrega a carta a Penelope. A jovem se queixa: "O resto das nossas famílias está preso na Idade das Trevas ou...")

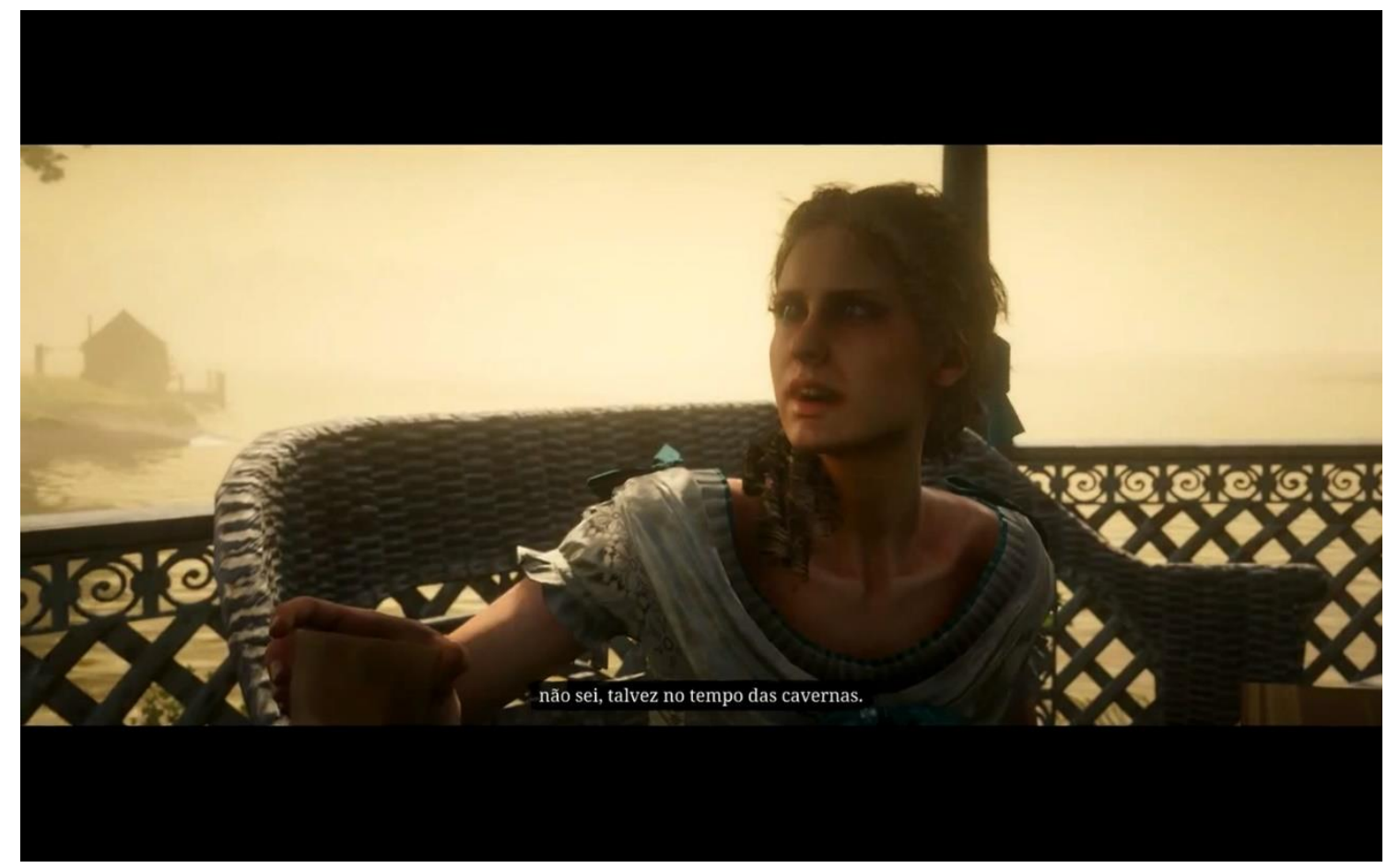

(Figura 3.12 - "não sei, talvez no tempo das cavernas.")

Há aqui uma relação intertextual com a clássica narrativa de Romeo e Julieta de William Shakespeare. Se checarmos a conclusão do Ato I, temos: 
AMA

Por Deus, rapaz!

A mãe dela é a dona desta casa

E é uma dama prudente e virtuosa.

Amamentei a jovem senhorita

Com quem vossa mercê andou falando.

Homem de sorte é quem casar com ela!

ROMEU A moça é Capuleto? Ah, minha vida,

Agora estás na conta do inimigo!

(...)

JULIETA E aquele outro, o que não quis dançar?

AMA Não sei.

JULIETA Pergunta o nome. Se ele for casado,

No túmulo farei o meu noivado.

AMA Ele é Romeu, Montéquio, único filho

De vosso mais terrível inimigo.

JULIETA Do meu único ódio, o amor levanta e arde:

Precocemente visto, e conhecido tarde.

É um prodígio este amor que nasce conturbado:

Pois devo agora amar quem me é mais detestado. (SHAKESPEARE, 2016, p. 91-92).

Após a comparação dos textos, checamos haver uma relação intertextual não de paráfrase, mas de estilização, pois em Red Dead Redemption II, Arthur une o casal proibido, que consegue fugir de Rhodes.

Essa pequena quantidade de exemplos brevemente analisados nos serviu para contextualizar a intertextualidade manifesta nas mídias, porém, debruçaremo-nos sobre o principal objeto de estudo desta pesquisa, a narrativa de The Witcher III: Wild Hunt e analisaremos com mais detalhes as relações intertextuais do enredo com textos considerados clássicos da cultura ocidental. 


\subsection{Análise da intertextualidade em The Witcher III: Wild Hunt}

Como já contextualizamos ao longo deste trabalho, os jogos da série The Witcher foram produzidos pela empresa CD Projekt com o intuito de dar continuidade à narrativa inicial de Andrzej Sapkowski, composta por sete livros, que narra as peripécias de Geralt de Rívia.

O recurso de intertextualidade é bastante presente na narrativa do jogo conclusivo da trilogia, seja somente como um toque delicado para despertar um estalo na mente do jogador $^{46}$, seja em percursos narrativos que pouco a pouco vão dando sinais ao jogador de estar vivenciando acontecimentos que aludem a contos de fada e outros textos da Literatura.

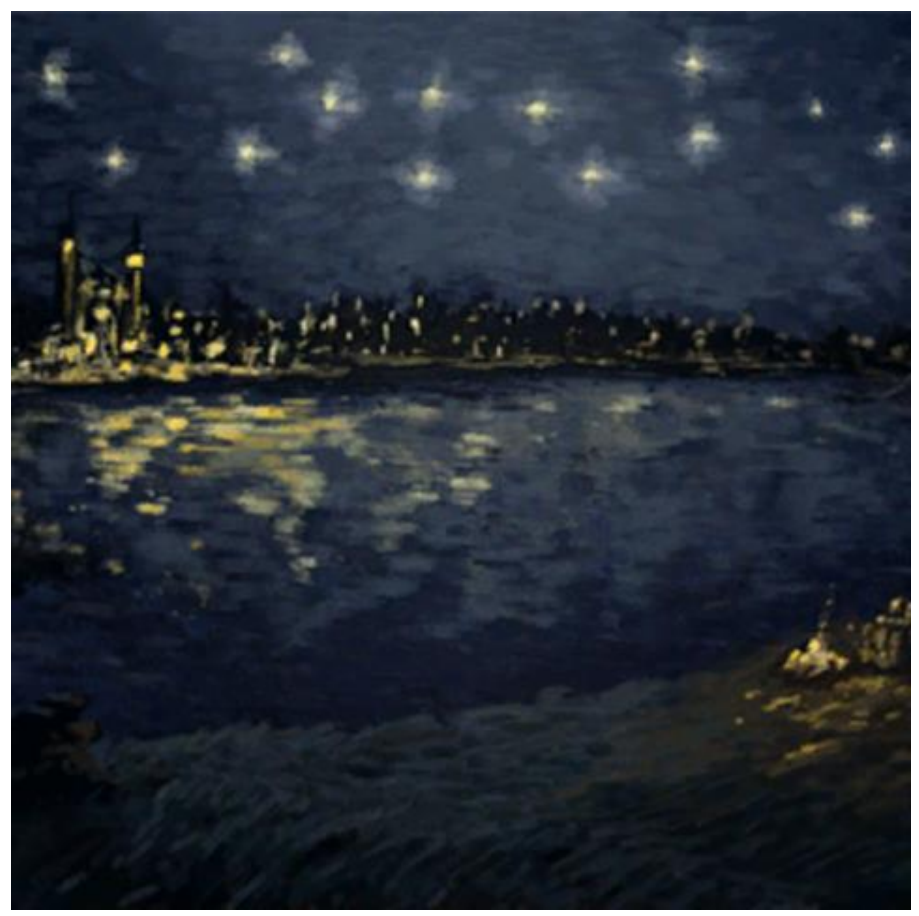

(Figura 3.13 - "Noite estrelada sobre o Pontar", de Van Rogh. Quadro leiloado na narrativa de The Witcher III: Wild Hunt, fazendo alusão intertextual à pintura de Van Gogh. Disponível em: https://witcher.fandom.com/wiki/\%22Starry_Night_Over_the_Pontar\%22, acesso em 21/01/2020)

\footnotetext{
${ }^{46}$ Como exemplo, podemos citar o episódio do Leilão Borsodi, em que Geralt participa de um evento em que pode comprar peças de arte e outras raridades e é oferecido um quadro intitulado "Noite estrelada sobre o Pontar", do pintor Van Rogh.
} 


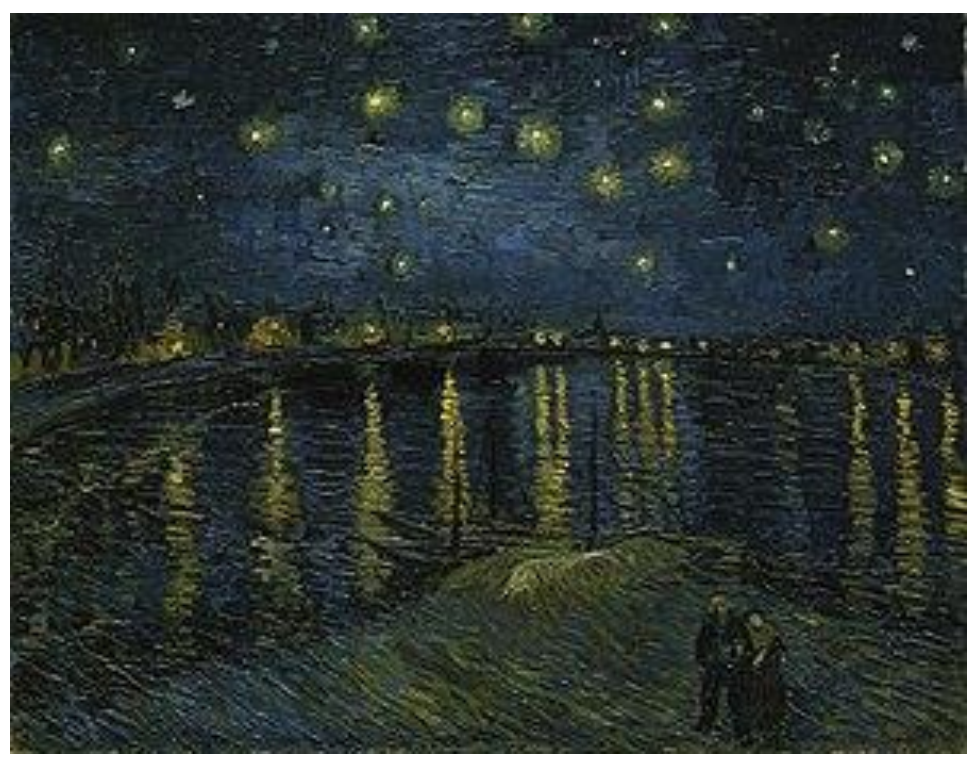

(Figura 3.14 - "Noite estrelada sobre o Ródano", de Van Gogh. Disponível em: https://pt.wikipedia.org/wiki/Noite_Estrelada_Sobre_o_R\%C3\%B3dano:, acesso em 21/01/2020)

Vale ressaltar que, para analisarmos as semelhanças e as diferenças entre os textos-base e as suas respectivas variantes intertextuais, lançaremos mão do arcabouço teórico desenvolvido pelo grupo de Paris, dirigido por Algirdas Julien Greimas. Analisaremos o texto-base e, em seguida, o texto variante, para então identificarmos qual é o tipo de relação intertextual entre ambos: paráfrase, estilização, paródia ou polêmica.

Ressaltamos ainda que The Witcher III: Wild Hunt é um jogo eletrônico de gênero RPG de ação, em que, periodicamente pela narrativa, o jogador tem a liberdade de escolher as falas do protagonista, o que pode acarretar em resultados diferentes dependendo da situação em que é colocado, como ajudar ou não um vilarejo em perigo. Explanado isto, esclarecemos que, para análise, só consideraremos os episódios cujas escolhas tomadas culminam em narrativas que se configuram como variantes intertextuais, ou seja, não é nosso objetivo analisar todas as possibilidades narrativas desencadeadas de escolhas do jogador se estas não desenvolverem a narrativa em si como uma variante intertextual.

Também é necessário frisar que, não por questão exaustiva, mas demonstrativa, buscamos um caso de variante que se configurasse como cada uma das quatro possibilidades: paráfrase, estilização, paródia ou polêmica, com o intuito de apresentar a riqueza de produção de sentido dentro da esfera narrativa de The Witcher III. Entretanto, adiantamos que não foram encontradas no jogo qualquer variante que pudesse ser 
considerada paráfrase, já que, para isso, é necessário que a variante assimile totalmente o texto-base (DISCINI, 2004, p. 72), o que não ocorre nas narrativas presentes no jogo eletrônico.

\subsubsection{Uma torre cheia de ratazanas}

Primeira a se analisar é a relação intertextual entre a missão do jogo "Uma torre repleta de ratazanas" e o conto "A bela adormecida no bosque", de Charles Perrault. O enredo de Bela adormecida pode ser dividido em duas partes. A inicial se resume à tão esperada filha de um rei e uma rainha que, ao nascer, é presenteada com uma festa. No evento, várias fadas são convidadas, porém, surge uma fada velha, "que não tinha sido convidada porque fazia mais de cinquenta anos não saía de uma torre, e todos achavam que estava morta ou enfeitiçada" (PERRAULT, 2015, p. 25). A fada velha amaldiçoa a garota, jogando-lhe um feitiço fatal, dizendo que a princesa morreria ao furar a mão. Uma das fadas presentes tenta amenizar a maldição:

- Fiquem tranquilos, rei e rainha, sua filha não vai morrer por isso: é bem verdade que não tenho poder suficiente para desfazer por inteiro o que a velhinha fez. A princesa vai furar a mão com um fuso, mas, em vez de morrer, só vai cair em sono profundo durante cem anos, e, passado esse tempo, o filho de um rei virá acordá-la. (Idem, p. 26).

Apesar de o rei ordenar o fim da costura com fuso, ao completar quinze anos, a jovem princesa encontra uma senhora fiando em uma das casas de campo da família e espeta a mão no fuso, caindo em sono profundo. A garota é alojada no melhor quarto do palácio e passa a dormir por cem anos. Todo o castelo é envolto magicamente por espinhos, o que afasta os curiosos por muito tempo. Até que o príncipe do século seguinte, em um dos seus dias de caça, encontra a construção abandonada, seguindo a lenda que lhe contaram:

- Príncipe, há mais de cinquenta anos ouvi de meu pai que naquele castelo havia uma princesa, a mais bela do mundo; que deveria dormir ali cem anos, e que seria acordada pelo filho de um rei, a quem ela estava reservada. (Idem, p. 29). 
Ao se aproximar do local, os espinhos e as trepadeiras se movem e deixam o príncipe adentrar o castelo. Lá, encontra a princesa e a desperta de seu sono.

Aproximou-se tremendo e admirado e ficou de joelhos ao lado dela.

Então, como o fim do feitiço chegara, a princesa acordou e, olhando-o com olhos mais afetuosos do que parece permissivel num primeiro encontro, disse:

- É o senhor, meu príncipe? Como se fez esperar!

O príncipe, encantado com essas palavras e mais ainda com a maneira como eram ditas, não sabia como demonstrar a alegria e o reconhecimento que sentia; afirmou que a amava mais do que a si mesmo. Suas frases saíram maltorneadas e por isso mesmo agradaram mais: menos eloquência e mais amor. (Idem, p. 31, grifos nossos).

Após o despertar da princesa, tem-se início o que consideramos a segunda parte da narrativa, em que a moça se une ao príncipe e se torna alvo da própria sogra. Como a missão "Uma torre repleta de ratazanas" alude intertextualmente só à primeira parte do conto, abriremos mão da segunda.

Ao analisar a primeira parte do conto de Perrault sob a perspectiva da semiótica francesa e aplicá-la ao percurso gerativo elaborado por Greimas, podemos dizer que no nível fundamental temos uma oposição semântica entre /vida/ e /morte/. Consideramos /vida/ como eufórica, já que desde o começo do conto temos o casal real feliz pela vinda de uma criança que tanto esperava, e /morte/ como disfórica, por estar na maldição da fada velha e mover o rei a realizar um decreto de proibição de costura com fuso em seu reino. Ao furar o dedo e dar início à maldição anunciada pela fada má, a princesa entra em disjunção com a /vida/, porém, graças à magia amenizadora da última fada que a presenteou em seu nascimento, não conjunge com a /morte/, repousando por cem anos em um estado letárgico de /não-vida/ até o predestinado príncipe despertá-la. 


\section{Quadrado semiótico \\ Bela adormecida}

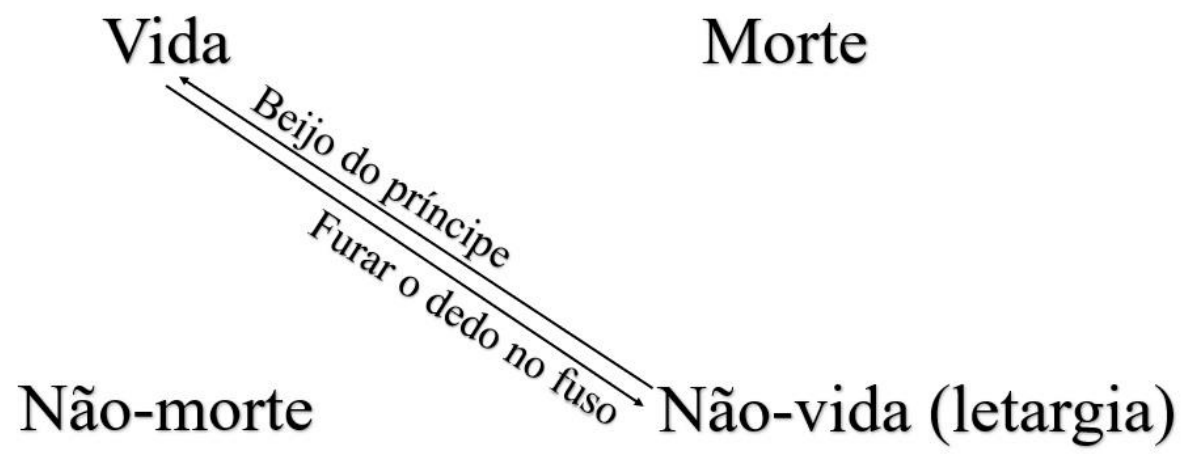

(Figura 3.15 - Quadrado semiótico do nível fundamental de Bela Adormecida)

Narrativamente, consideramos o ator príncipe como o sujeito do fazer. Um conhecido lhe informa da lenda da princesa adormecida, manipulando-o a ir atrás de seu objeto de valor. O sujeito quer salvá-la da maldição e sente que deve. Apesar de não ter o saber exato para isso, já que vai em busca da amada baseado em rumores, tem o poder, por ser o predestinado pela profecia elucidada pela fada na festa comemorativa do nascimento da princesa. O sujeito realiza a sua performance através de seu amor, despertando a moça e libertando-a de sua maldição, sendo sancionado positivamente por ela.

\section{Programa narrativo do príncipe}

\begin{tabular}{|c|c|c|c|c|}
\hline \multicolumn{2}{|c|}{ Manipulação } & Competência & Performance & Sanção \\
\hline \multicolumn{2}{|c|}{ Destinador $\rightarrow$ Sujeito } & Poder dado & Sujeito $\cap$ Objeto & Positiva \\
\hline 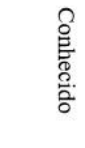 & 泀 & 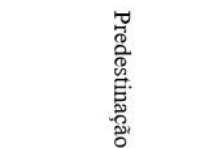 & 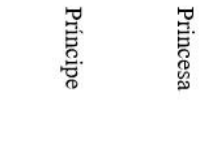 & 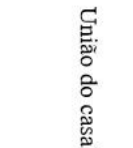 \\
\hline
\end{tabular}

(Figura 3.16 - Programa narrativo do príncipe.) 
Para checar o nível discursivo, inserimos uma tabela para exemplificar alguns dos temas e figuras que revestem a história de "A bela adormecida no bosque":

\begin{tabular}{|c|c|}
\hline Temas & Figuras \\
\hline Épico & $\begin{array}{c}\text { Castelo, príncipe, princesa, serviçais, } \\
\text { fada, floresta, maldição, casa de campo, } \\
\text { fuso }\end{array}$ \\
\hline Amor & $\begin{array}{c}\text { Beijo de amor verdadeiro, casamento, } \\
\text { amor parental }\end{array}$ \\
\hline Violência & Maldição \\
\hline
\end{tabular}

(Tabela 1 - Tabela de exemplos de temas e figuras no nível discursivo de "A bela adormecida no bosque". Autoria própria.)

Agora, foquemos em "Uma torre cheia de ratazanas". Buscando informações sobre o paradeiro de sua filha adotiva nos pântanos de Velen, Geralt encontra Keira Metz, uma velha amiga feiticeira. $\mathrm{O}$ encontro culmina em um pedido de ajuda por parte dela. Uma ilha próxima de sua casa tem um passado sombrio e todos os camponeses em torno creem estar amaldiçoada. Como Keira tem ajudado o povo local para se manter incógnita dos caçadores de bruxas, persuade Geralt a navegar até a ínsula e desfazer a maldição que a tomou, pois, se os habitantes locais não verem nela uma figura benéfica, podem entregar a sua localização às autoridades.

Segundo Keira, na ilha foi erguida uma torre na qual se escondeu Vserad, o senhor daquelas terras, e sua família, quando o império invadiu o território. Houve um grande conflito entre a família do lorde e os camponeses, que acabou com muito derramamento de sangue e a tal maldição. Para investigar o que ocorreu, a feiticeira entrega para Geralt uma lâmpada mágica que revela as últimas memórias de pessoas ao ser apontada para os seus ossos.

Até aqui, em questões de nível narrativo, temos Keira como destinadora de Geralt, manipulando-o a querer e dever investigar a ilha e lhe disponibilizando um objeto para que ele tenha a competência para desfazer a maldição e concluir seu percurso narrativo.

Ao chegar à torre da ilha, o protagonista descobre, investigando os restos dos mortos, que ocorreu um levante dos súditos de Vserad contra os nobres por conta de falta 
de alimentos. A plebe cria que o lorde havia se trancado na torre junto com sua família e o mago local para manterem toda a comida disponível da região. Além disso, Geralt percebe uma grande quantidade de ratos presentes na construção e corpos mais recentes, cujas memórias expostas pela lâmpada revelavam que, com o intuito de saquear o ouro que ficou para trás, eram atacados por algum tipo de monstro que se alojou lá depois do fim do conflito.

Examinando o quarto mais alto da torre, Geralt encontra o fantasma de Anabelle, a filha do lorde que morrera no dia do conflito, mas que ainda vaga pela torre.

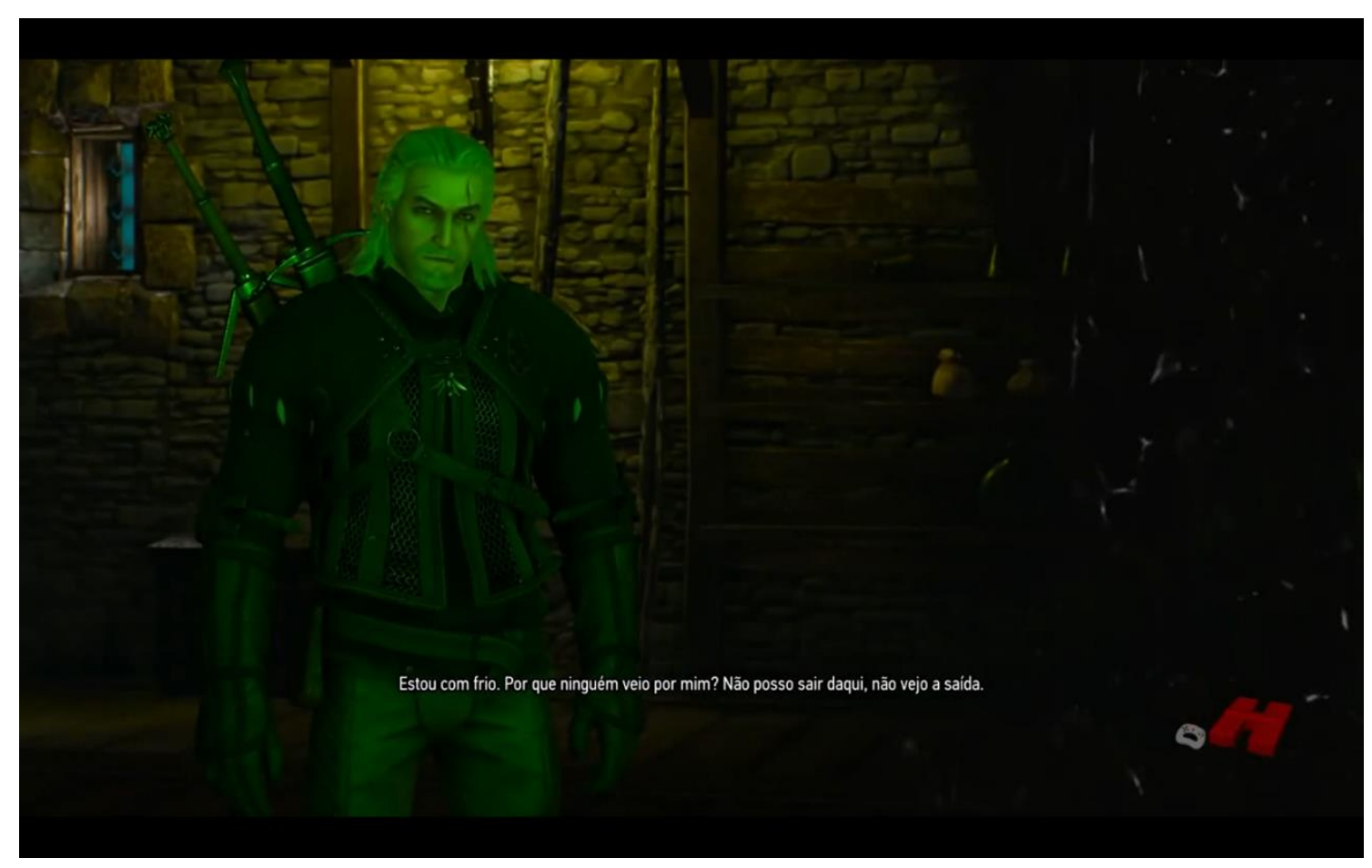

(Figura 3.17 - Geralt (à esquerda), encontra Anabelle (mancha negra à direita), espectro que diz não ver a saída da torre.)

Conversando com o espírito atormentado da moça, Geralt descobre que o mago da família entregou uma poção para Anabelle usar, caso os camponeses conseguissem invadir a torre. Ao indagar sobre a composição do líquido, a fantasma revela que não confiava no mago e que só puderam chegar até ela porque ouvira a voz de seu amado, Graham, entre eles. No entanto, os camponeses se apossaram dela e Graham não pôde impedi-los (ver Figuras 3.18 à 3.25). 


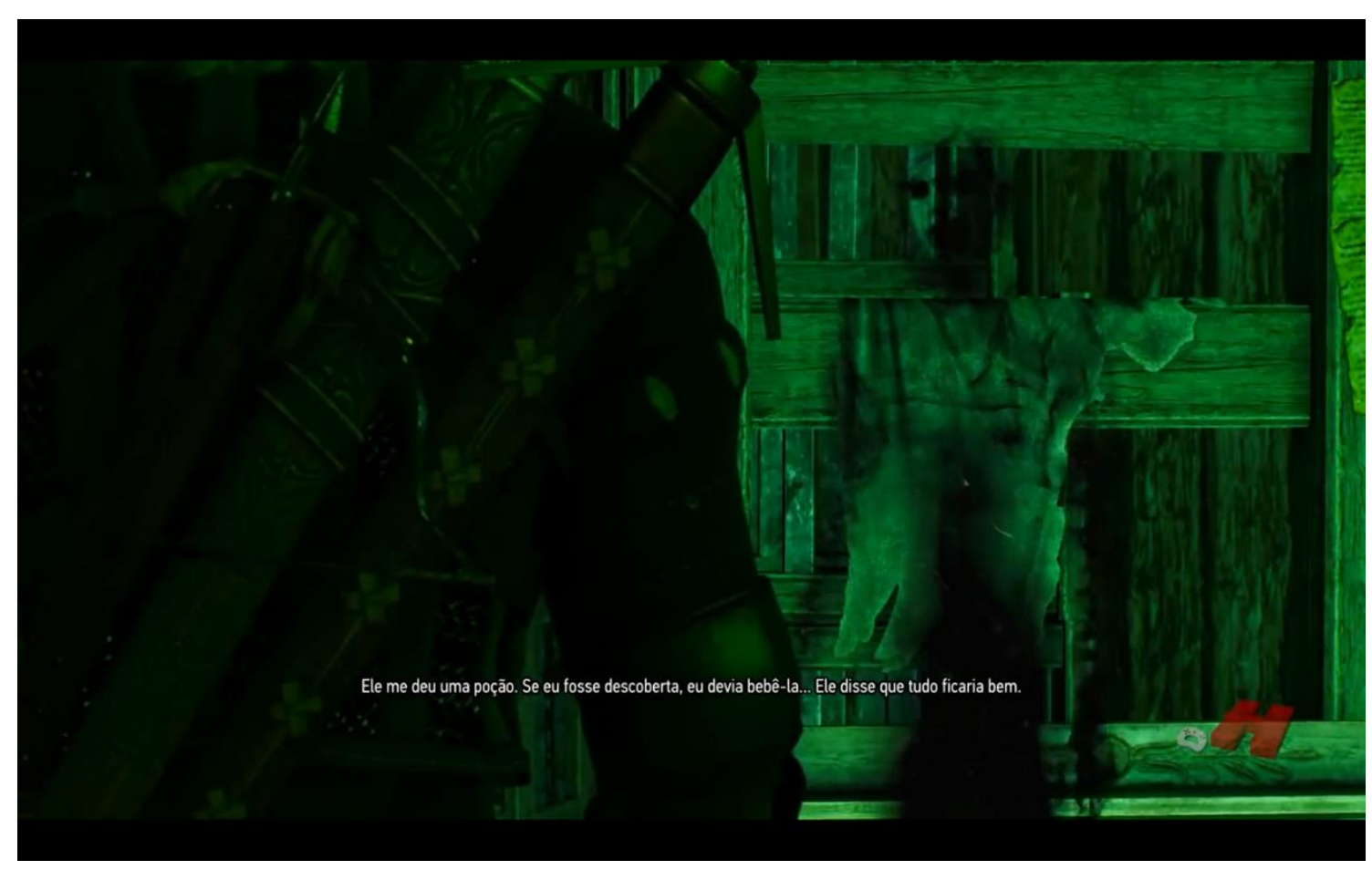

(Figura 3.18 - Anabelle diz: "Ele me deu uma poção. Se eu fosse descoberta, eu devia bebê-la... Ele disse que tudo ficaria bem.")

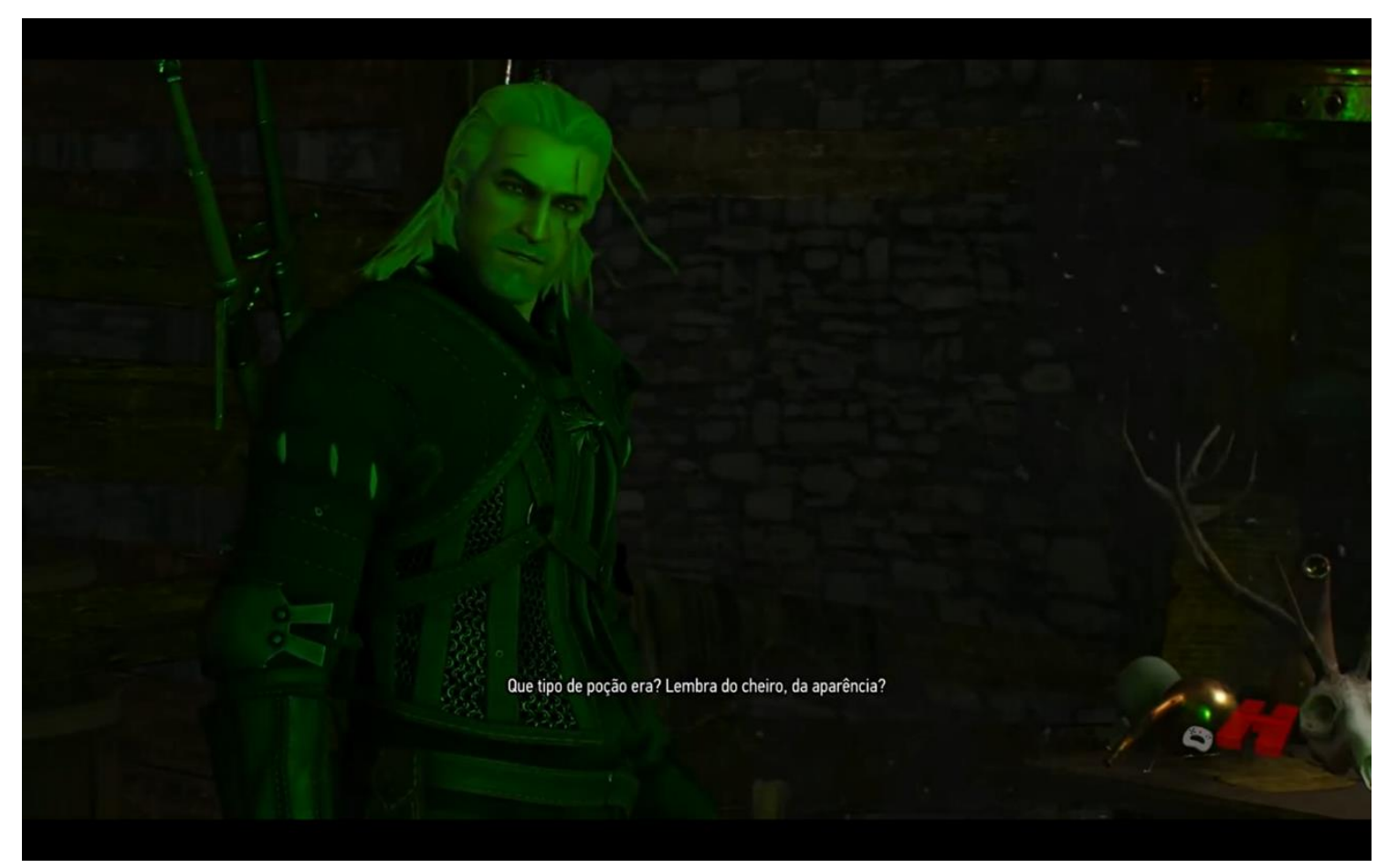

(Figura 3.19 - "Que tipo de poção era? Lembra do cheiro, da aparência?”) 


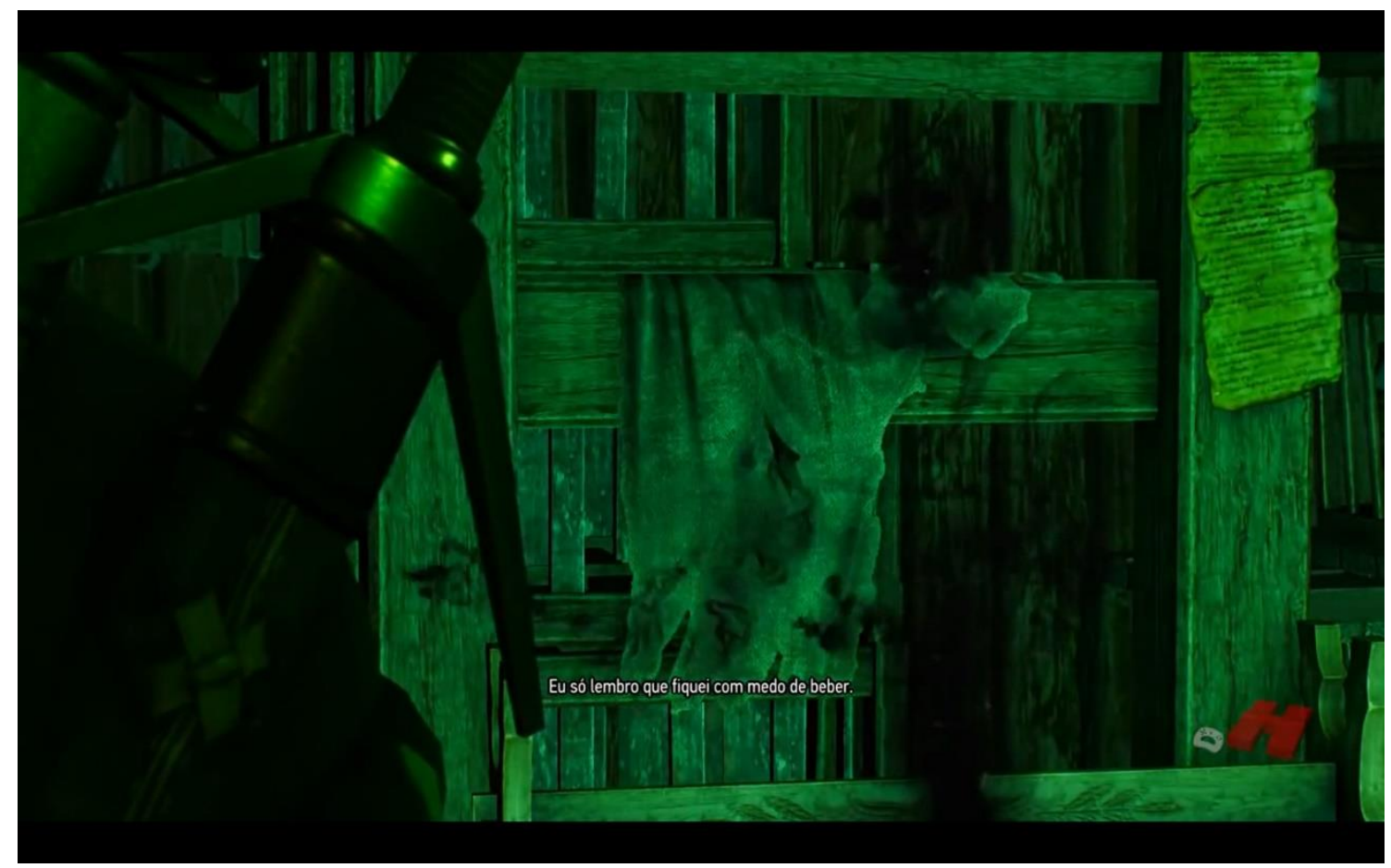

(Figura 3.20 - "Eu só lembro que fiquei com medo de beber.")

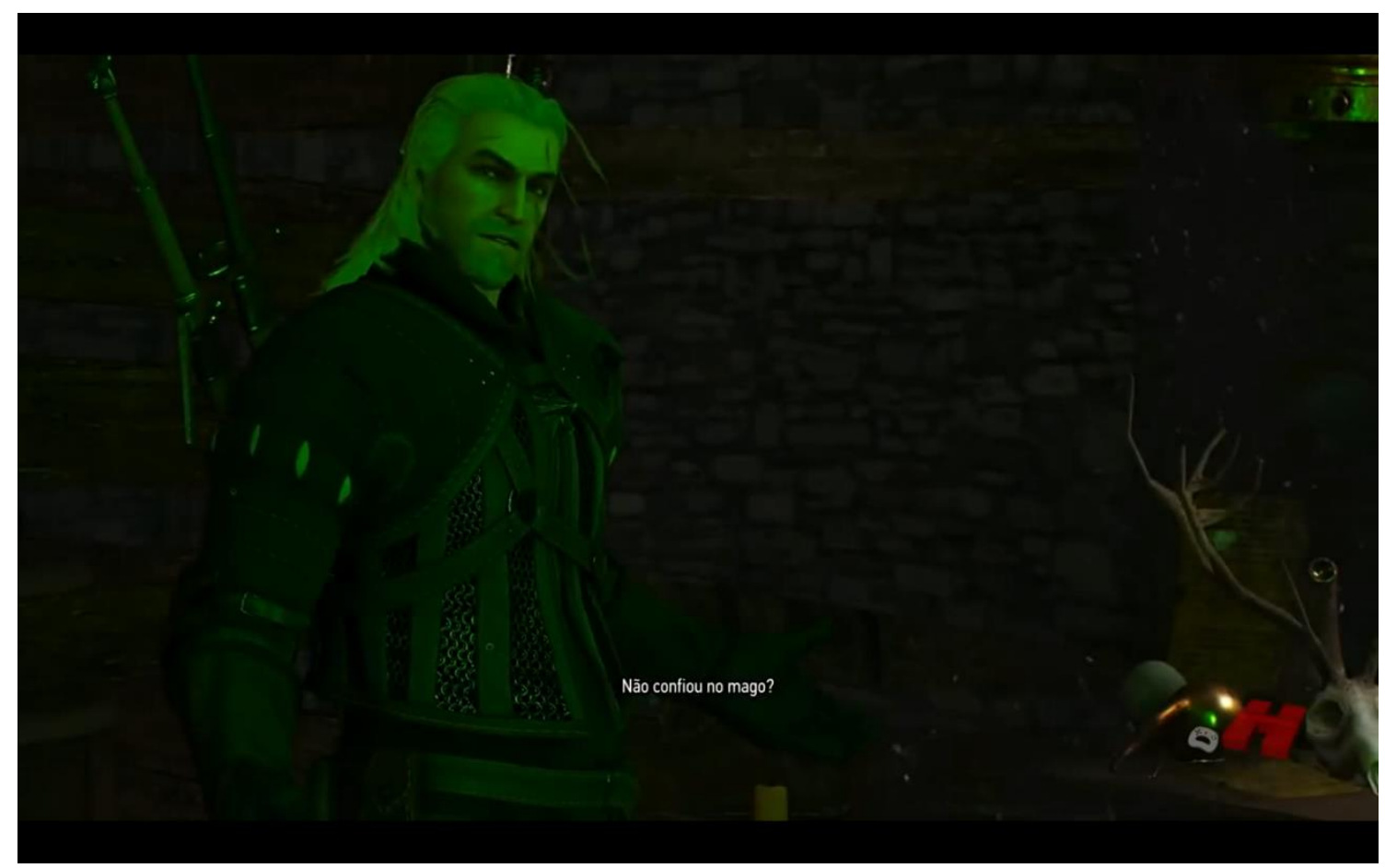

(Figura 3.21 - "Não confiou no mago?") 


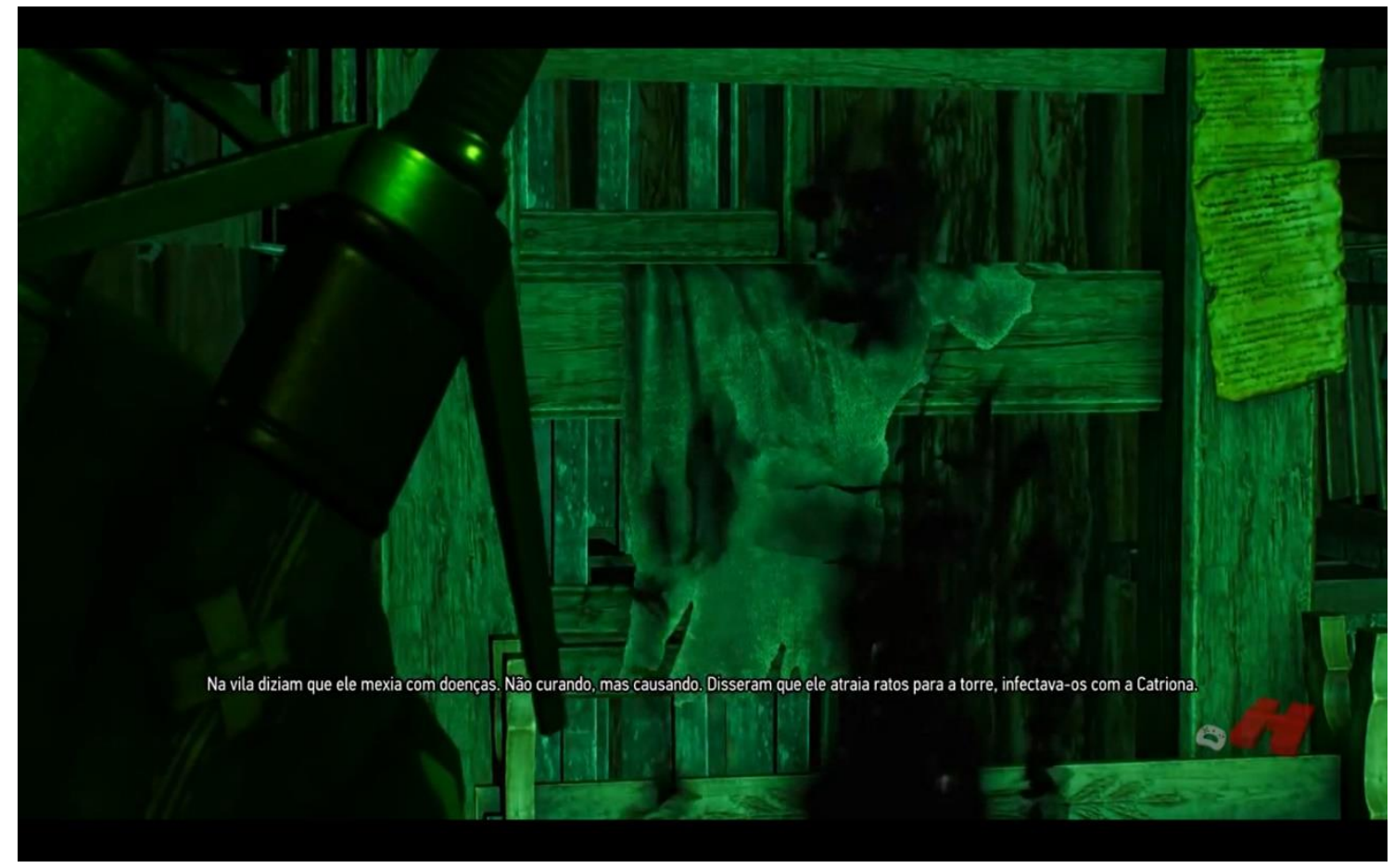

(Figura 3.22 - "Na vila diziam que ele mexia com doenças. Não curando, mas causando. Disseram que ele atraía ratos para a torre, infectava-os com a Catriona.")

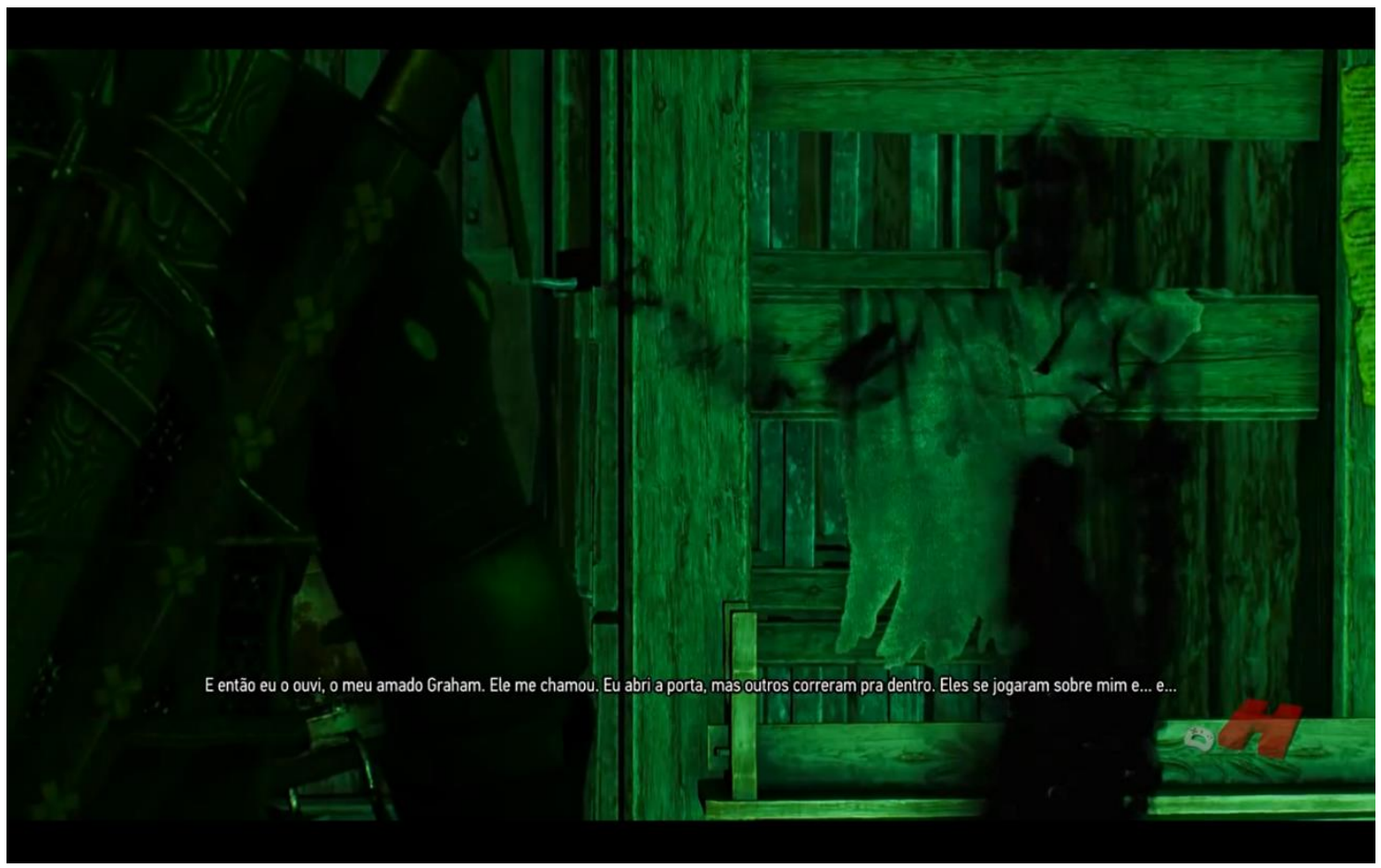

(Figura 3.23 - "E então eu o ouvi, o meu amado Graham. Ele me chamou. Eu abri a porta, mas os outros correram para dentro. Eles se jogaram sobre mim e... e...”) 


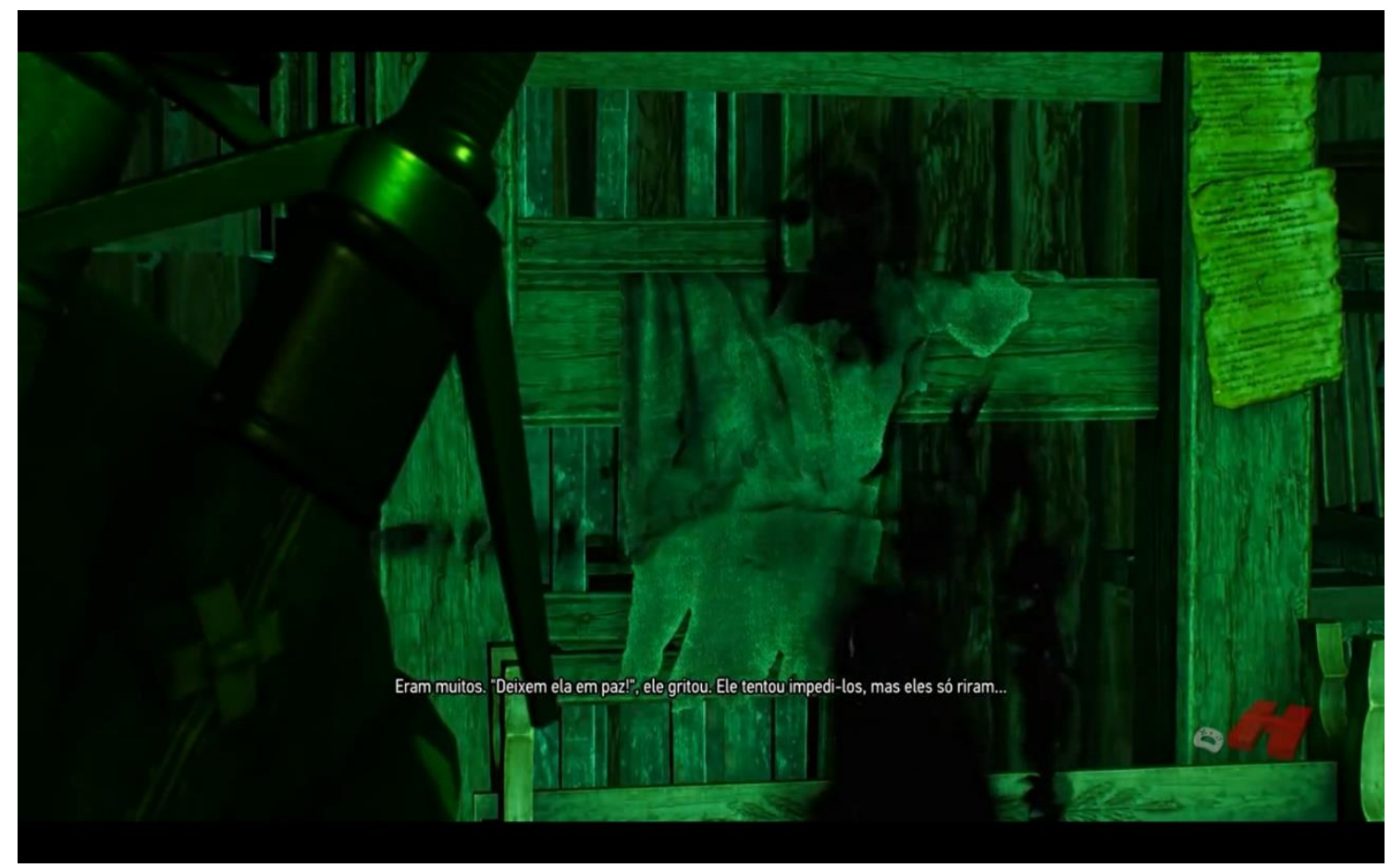

(Figura 3.24 - “Eram muitos. "Deixem ela em paz!”, ele gritou. Ele tentou impedi-los, mas eles só riram...")

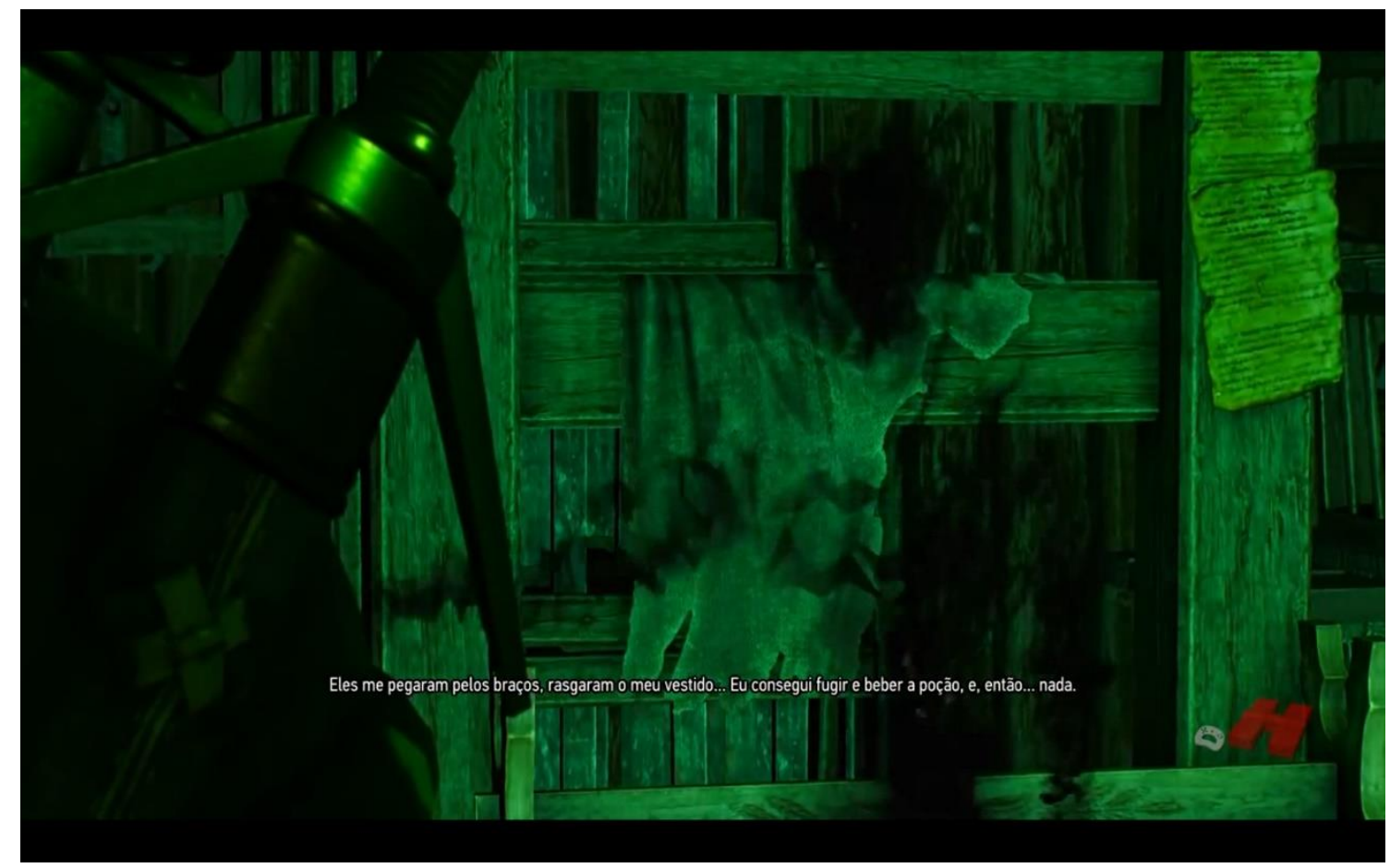

(Figura 3.25 - "Eles me pegaram pelos braços, rasgaram o meu vestido... Eu consegui fugir e beber a poção, e, então... nada.”)

Após Geralt perguntar se um veneno a tinha matado, Anabelle relata que acordou depois, completamente imóvel, em meio a inúmeros ratos, as cobaias com as quais o mago 
da torre infectava com a doença Catriona, que se amontoaram sobre ela e a devoraram viva (ver Figuras 3.26 e 3.27).

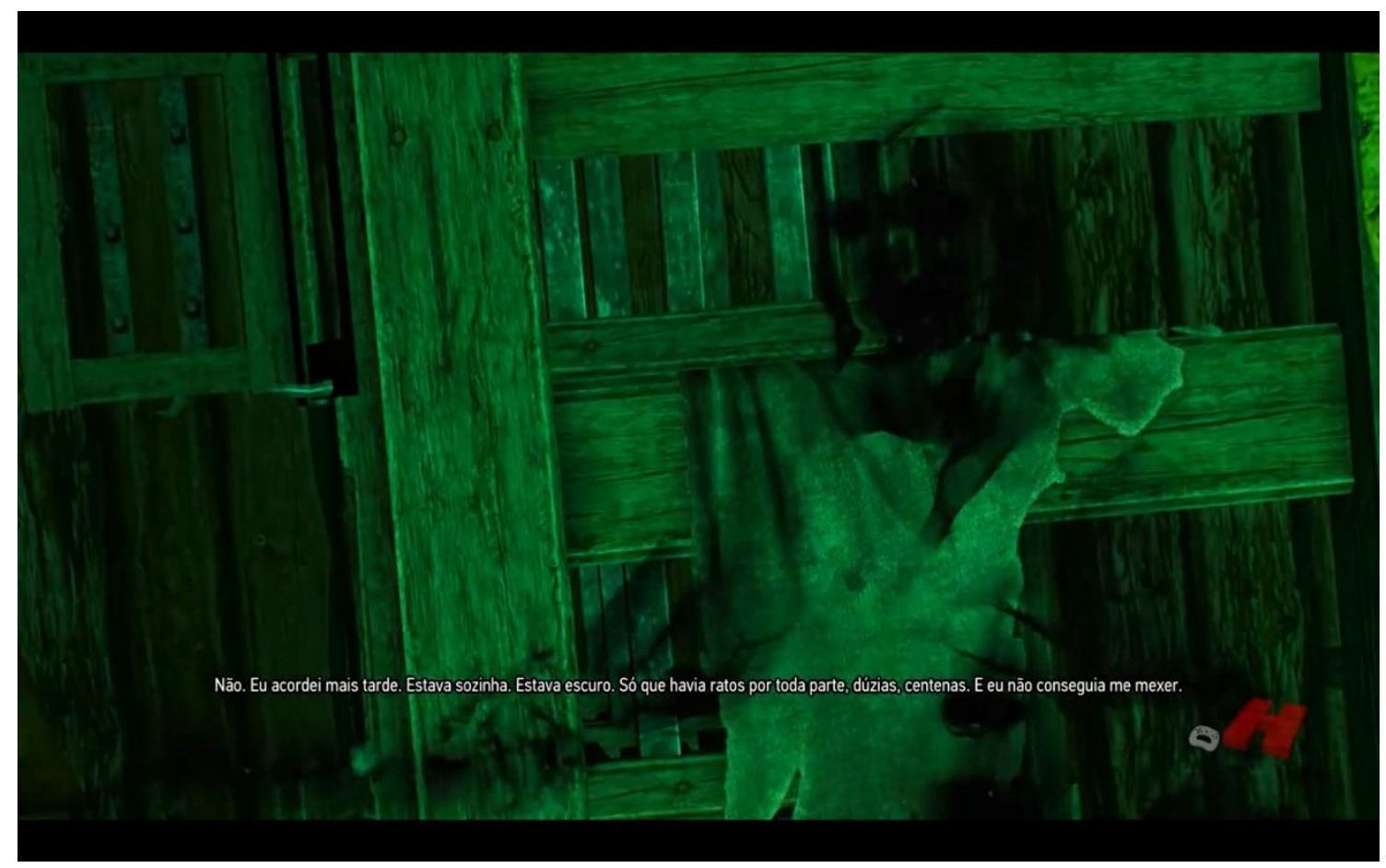

(Figura 3.26 - "Eu acordei mais tarde. Estava sozinha. Estava escuro. Só que havia ratos por toda parte, dúzias, centenas. E eu não conseguia me mexer.")

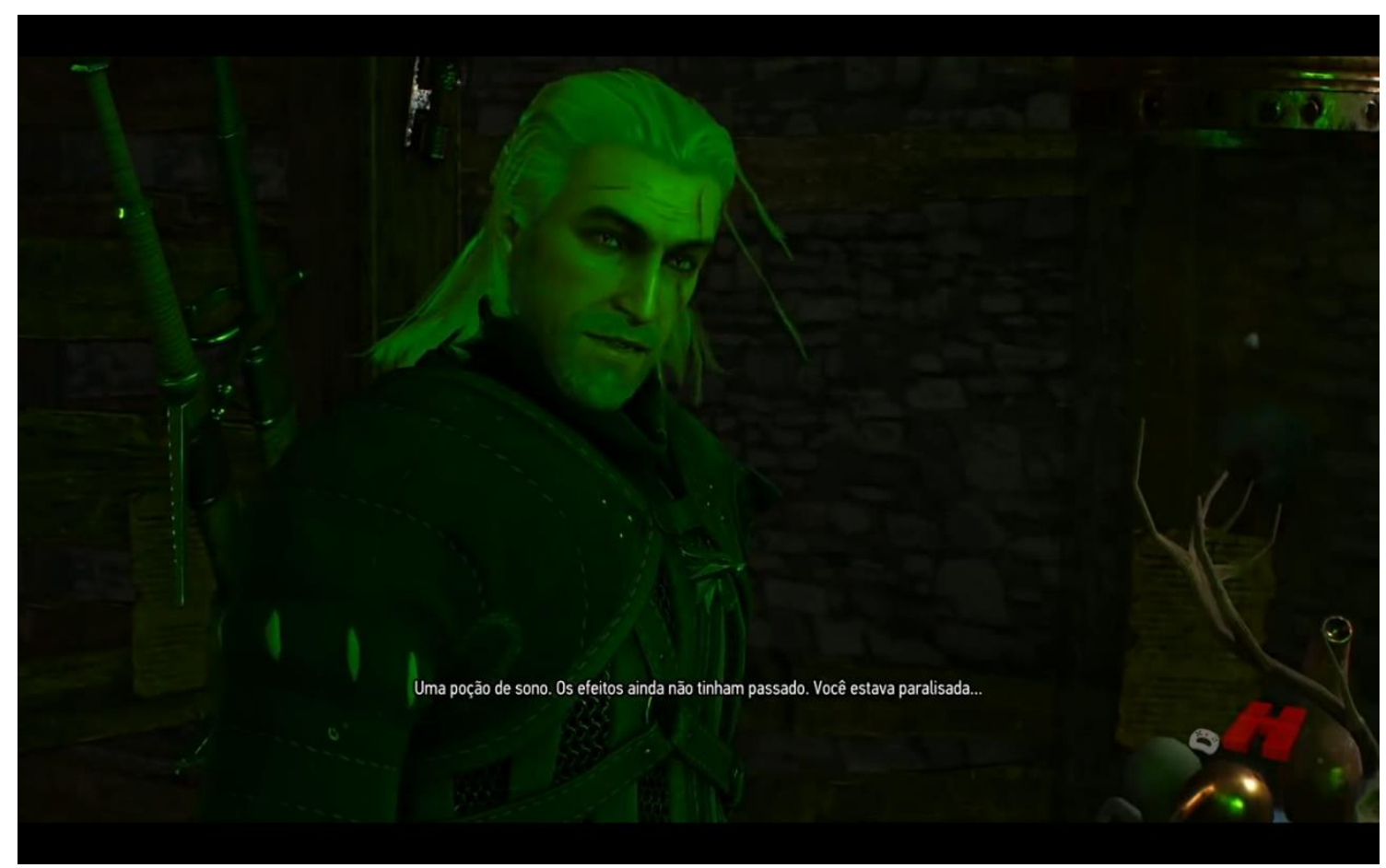

(Figura 3.27 - "Uma poção de sono. Os efeitos ainda não tinham passado. Você estava paralisada...") 
Geralt diz querer ajudar e Anabelle explica a sua condição, de modo que trazer o seu amor a libertaria de seu sofrimento.

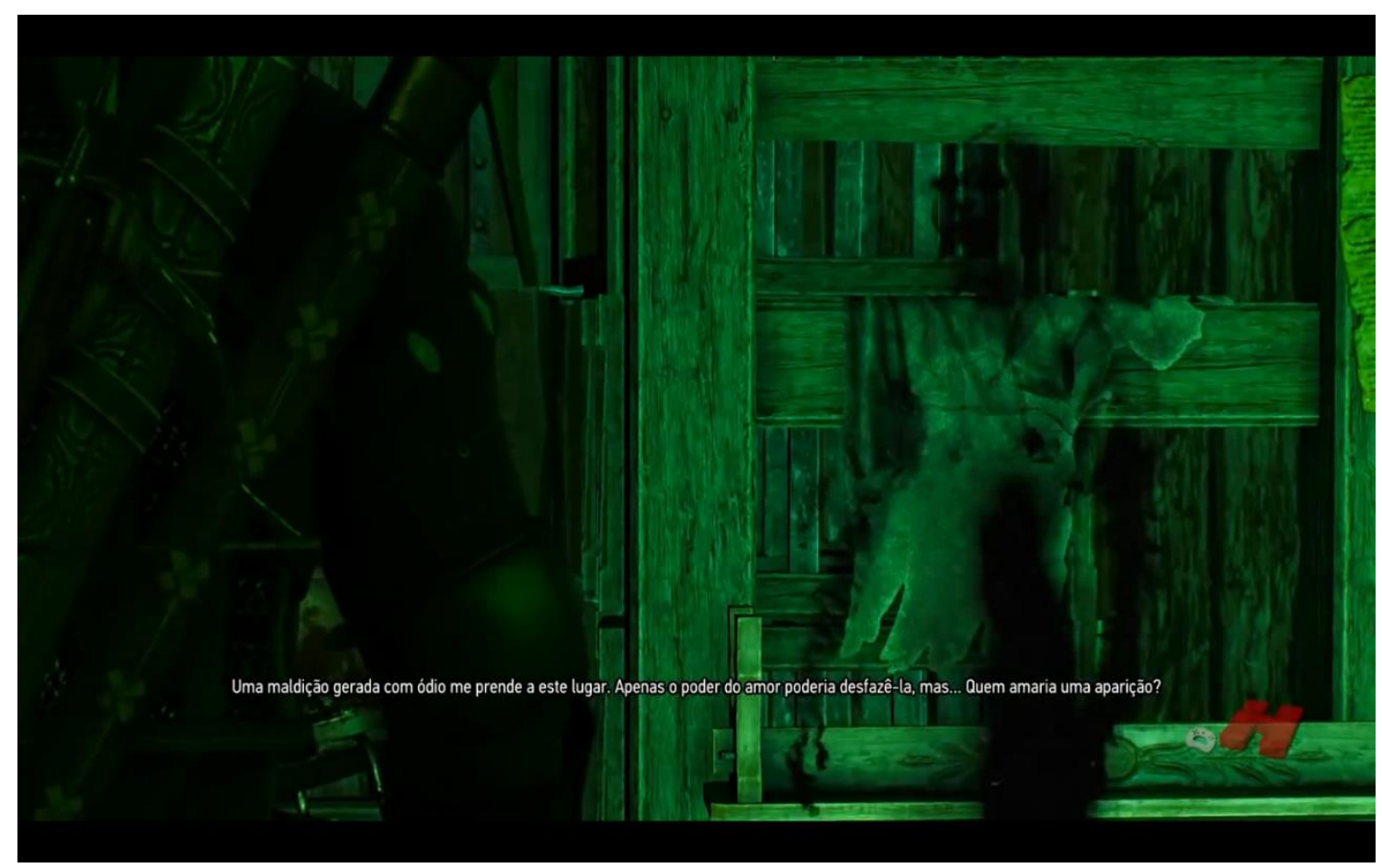

(Figura 3.28 - "Uma maldição gerada com ódio me prende a este lugar. Apenas o poder do amor poderia desfazê-la, mas... Quem amaria uma aparição?")

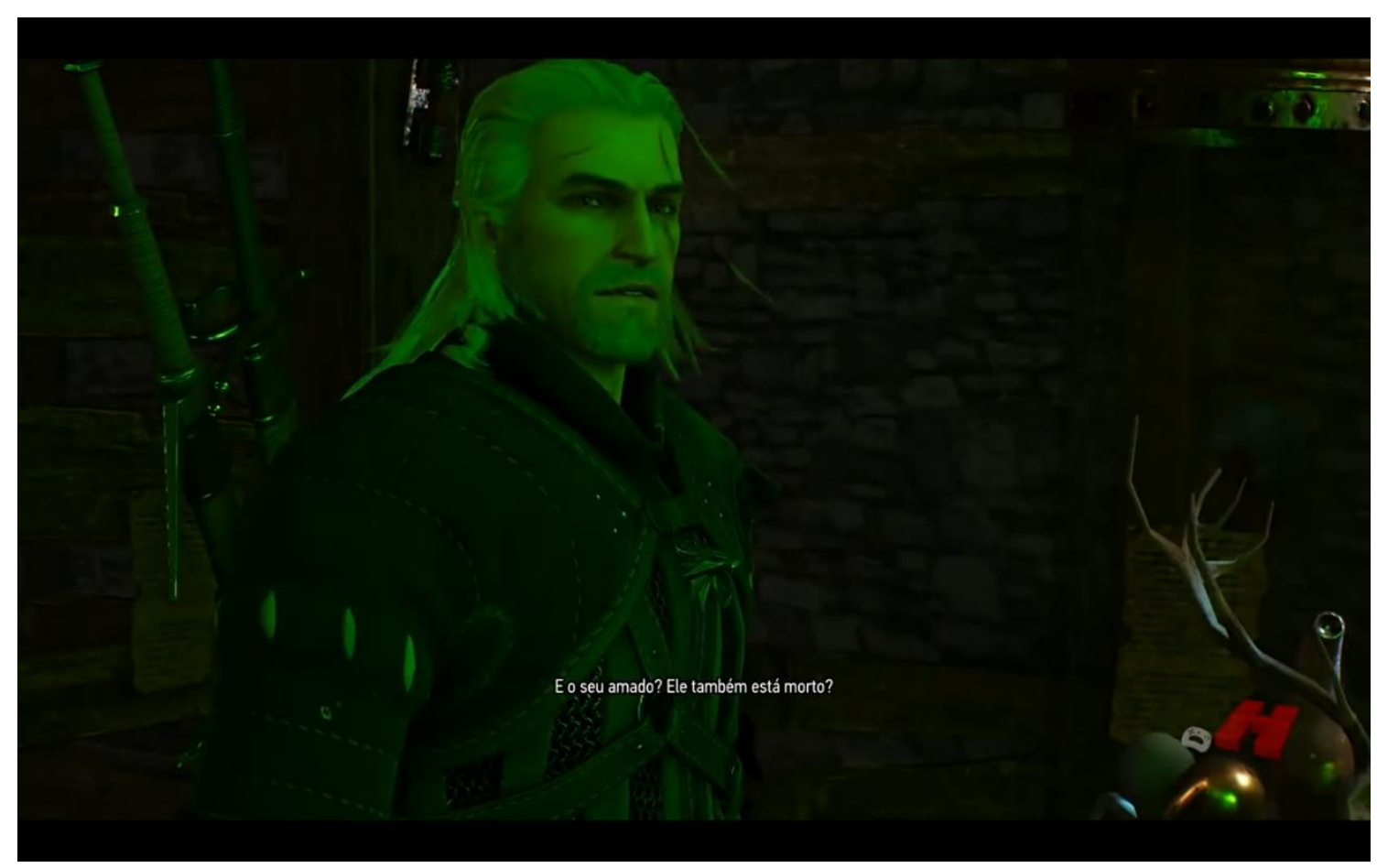

(Figura 3.29 - "E o seu amado? Ele também está morto?") 


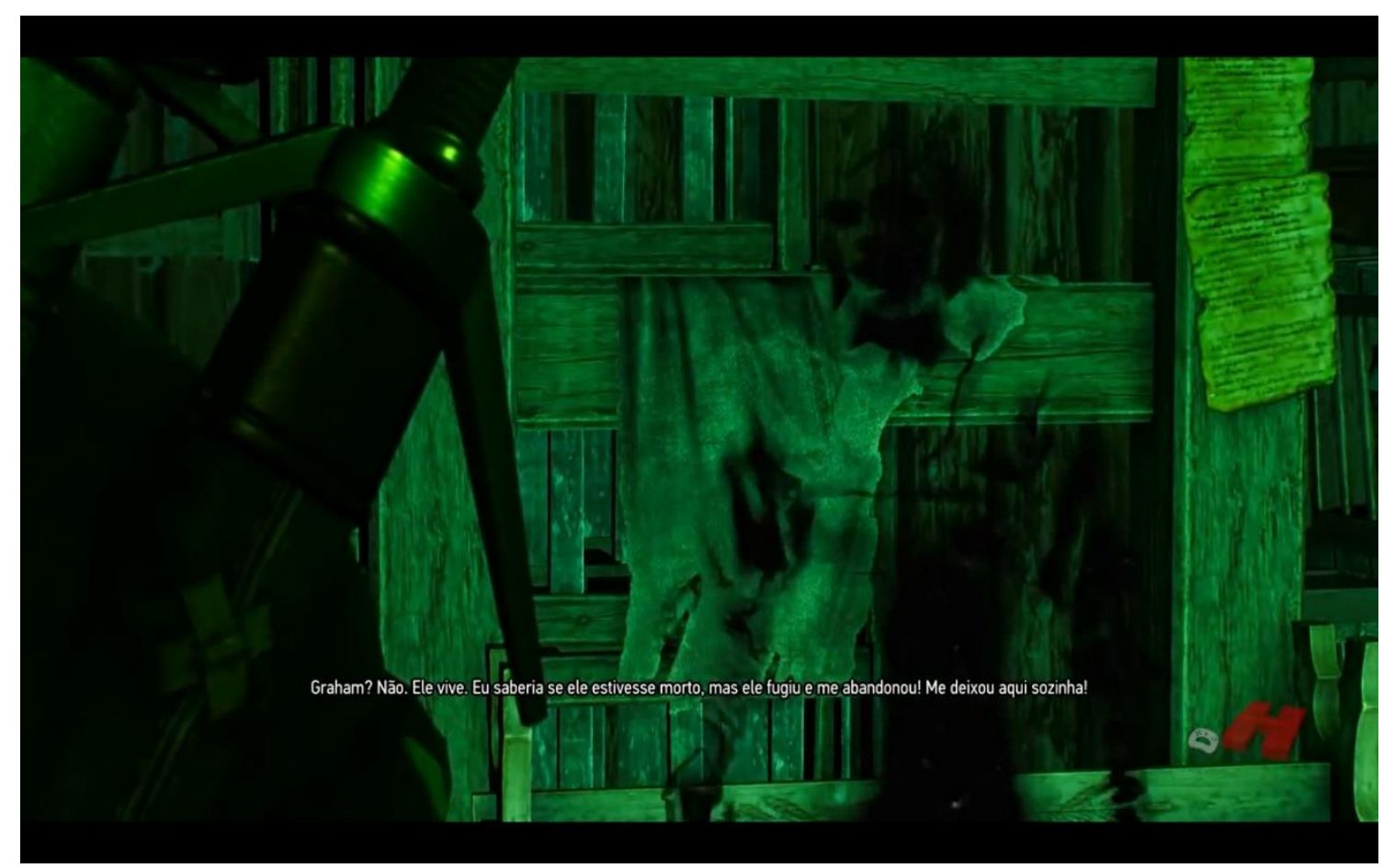

(Figura 3.30 - "Graham? Não. Ele vive. Eu saberia se ele estivesse morto, mas ele fugiu e me abandonou! Me deixou aqui sozinha!")

Geralt percebe o ódio no tom de voz do espectro, sugerindo que perdoar Graham poderia quebrar a maldição. No entanto, Anabelle pede a Geralt para que leve os seus ossos para o rapaz. Temendo carregar objetos amaldiçoados para fora da ilha, o protagonista recusa e então, a fantasma se enfurece, revelando-se um monstro designado por "bubônica" ou "dama da peste". Segundo a própria descrição do bestiário do jogo:

Quando uma praga assola uma região, um espírito às vezes perambula pelas suas terras, um fantasma parecido com o de uma mulher doente, cuja carne apodrecida parece cair dos seus ossos, seguida por uma rataria. Ninguém sabe se o espírito traz a peste consigo ou se é simplesmente atraído por ela. Porém é certo que ela sente prazer em causar dor e sofrimento, em ouvir os uivos e gemidos dos homens. (...)

Como o nome "Dama da peste" sugere, essas aparições assumem o aspecto de mulheres, embora o motivo disso ainda seja um mistério. Alguns especulam que, como os outros espectros, elas surgem de mudanças emocionais poderosas associadas a certas 
circunstâncias na morte, como uma morte precedida de uma doença particularmente longa e sofrida. ${ }^{47}$

Não conseguindo derrotá-la definitivamente em combate, Geralt decide procurar por Graham, o qual desconhecia que a namorada não havia morrido. O protagonista o informa, então, que só o amor verdadeiro pode quebrar a maldição e devolver a paz para a ilha (ver Figuras 3.31 à 3.33).

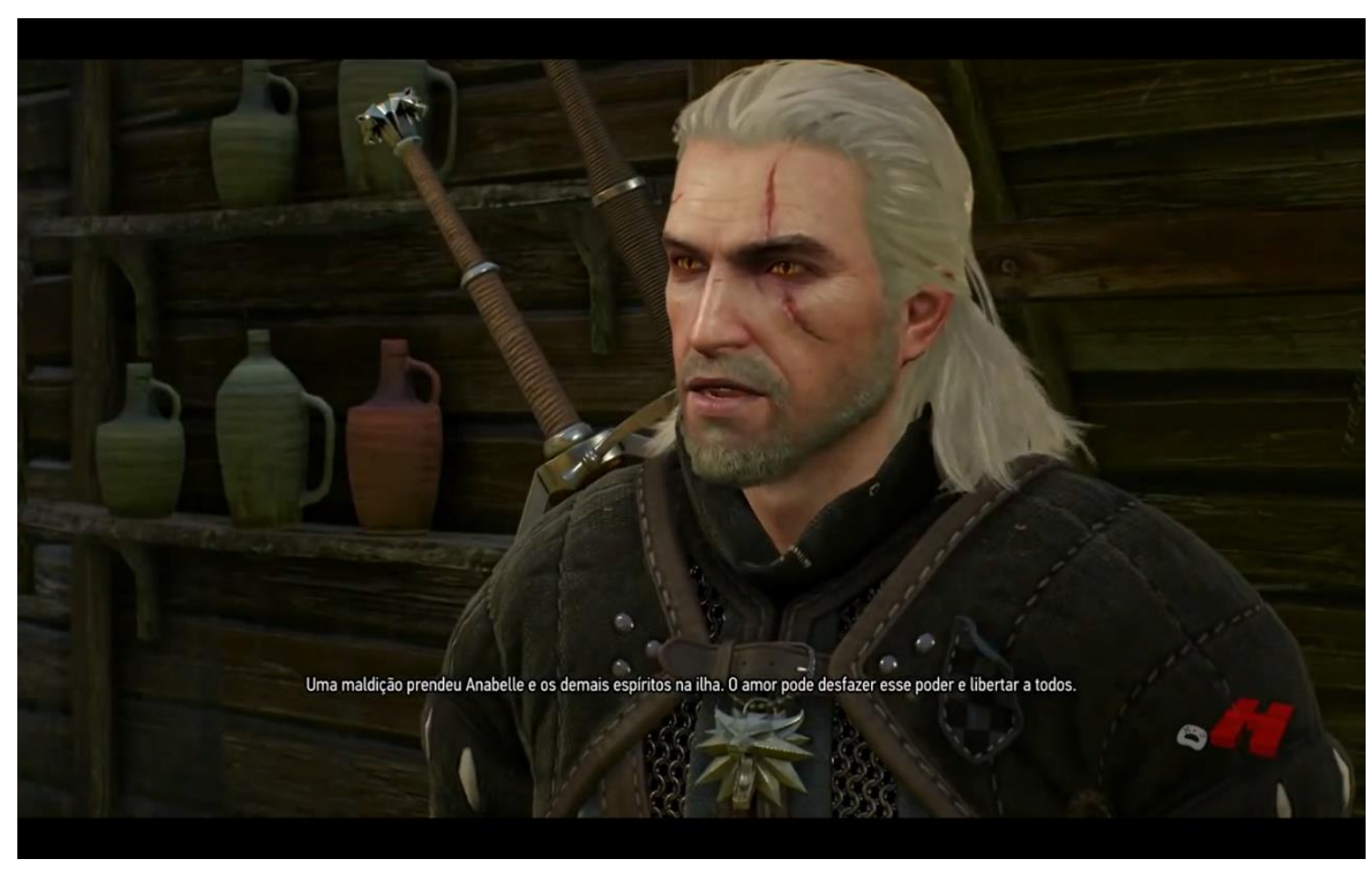

(Figura 3.31 - "Uma maldição prendeu Anabelle e os demais espíritos na ilha. O amor pode desfazer esse poder e libertar a todos.")

\footnotetext{
${ }^{47}$ Consultado em https://thewitcher.fandom.com/pt-br/wiki/Damas_da_Peste, acesso em 21/01/2020.
} 


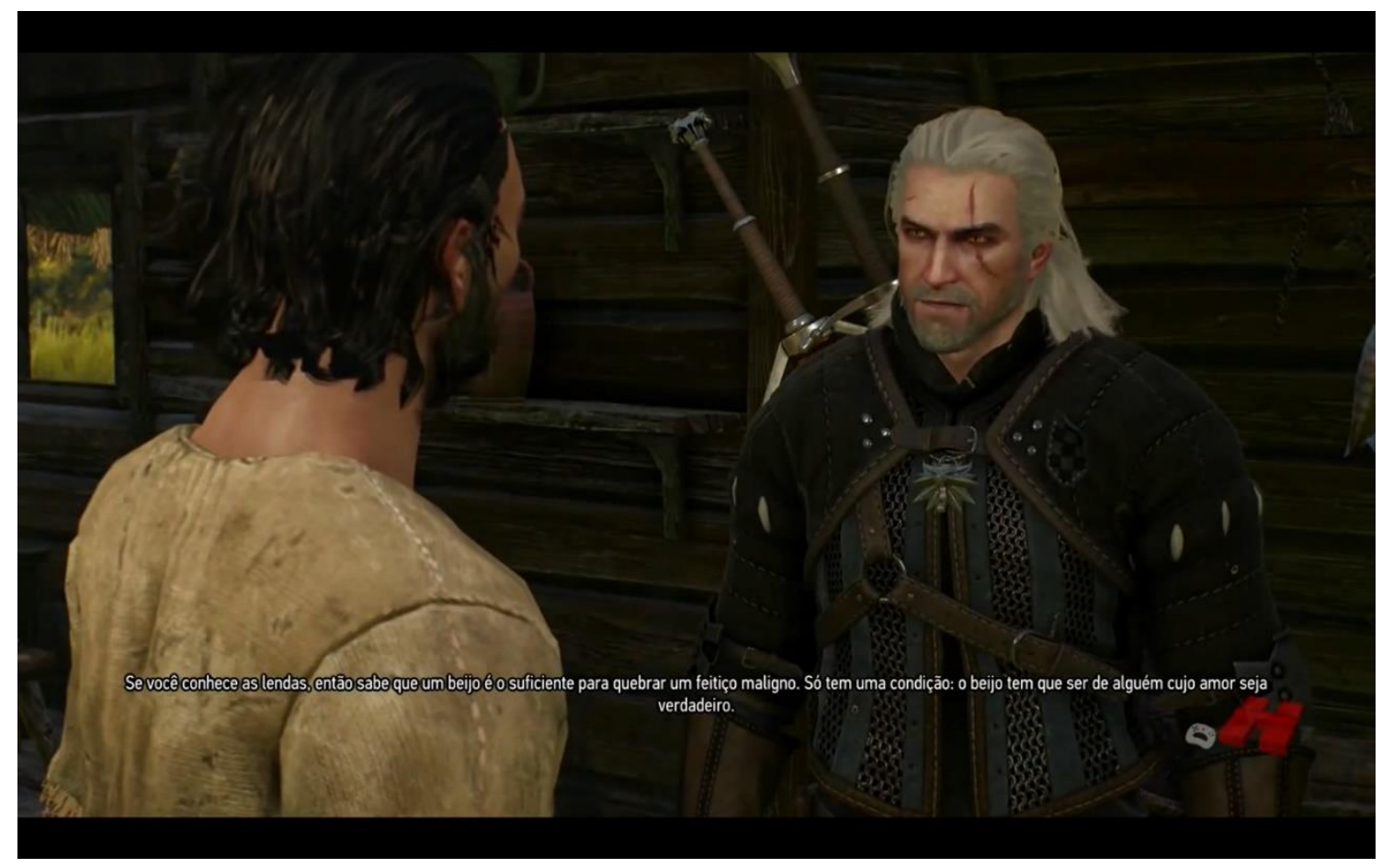

(Figura 3.32 - Geralt avisa Graham que o beijo tem que ser de alguém cujo amor seja verdadeiro.)

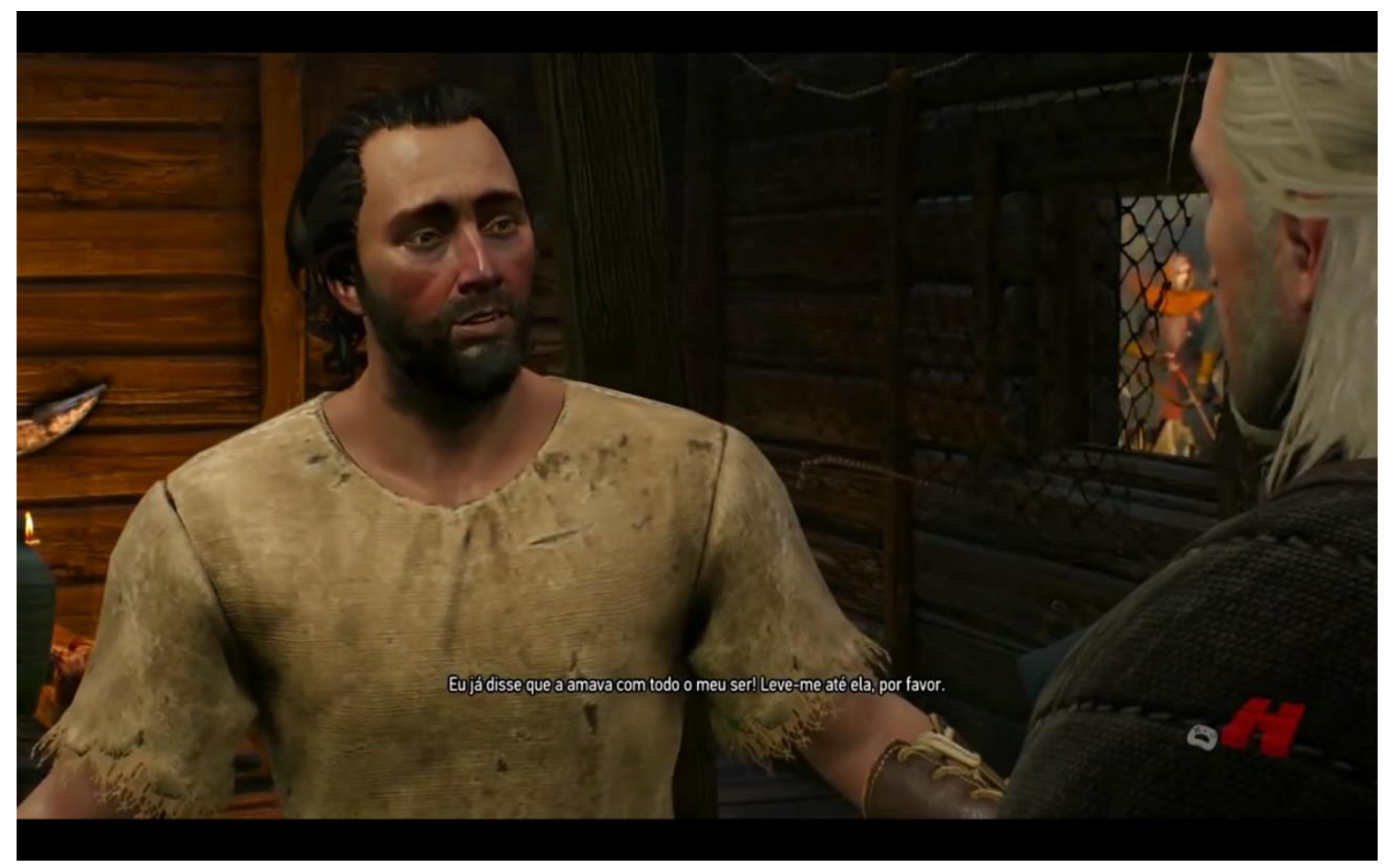

(Figura 3.33 - Graham diz amar Anabelle com todo o seu ser.)

O protagonista escolta Graham até a torre, protegendo-o dos outros espíritos atormentados que vagueiam por lá. Ao se apresentarem para Anabelle, o jovem pede perdão e alega que nunca a abandonaria se soubesse que ela ainda estava viva. A fantasma 
exige uma prova de amor, pedindo para que o namorado a beije na forma monstruosa em que ela se encontra. Ao beijar Anabelle, Graham quebra a maldição, transformando-a novamente em humana. Todavia, por se tratar de uma dama da peste, o jovem cai morto. Anabelle agradece Geralt e desaparece, liberta.

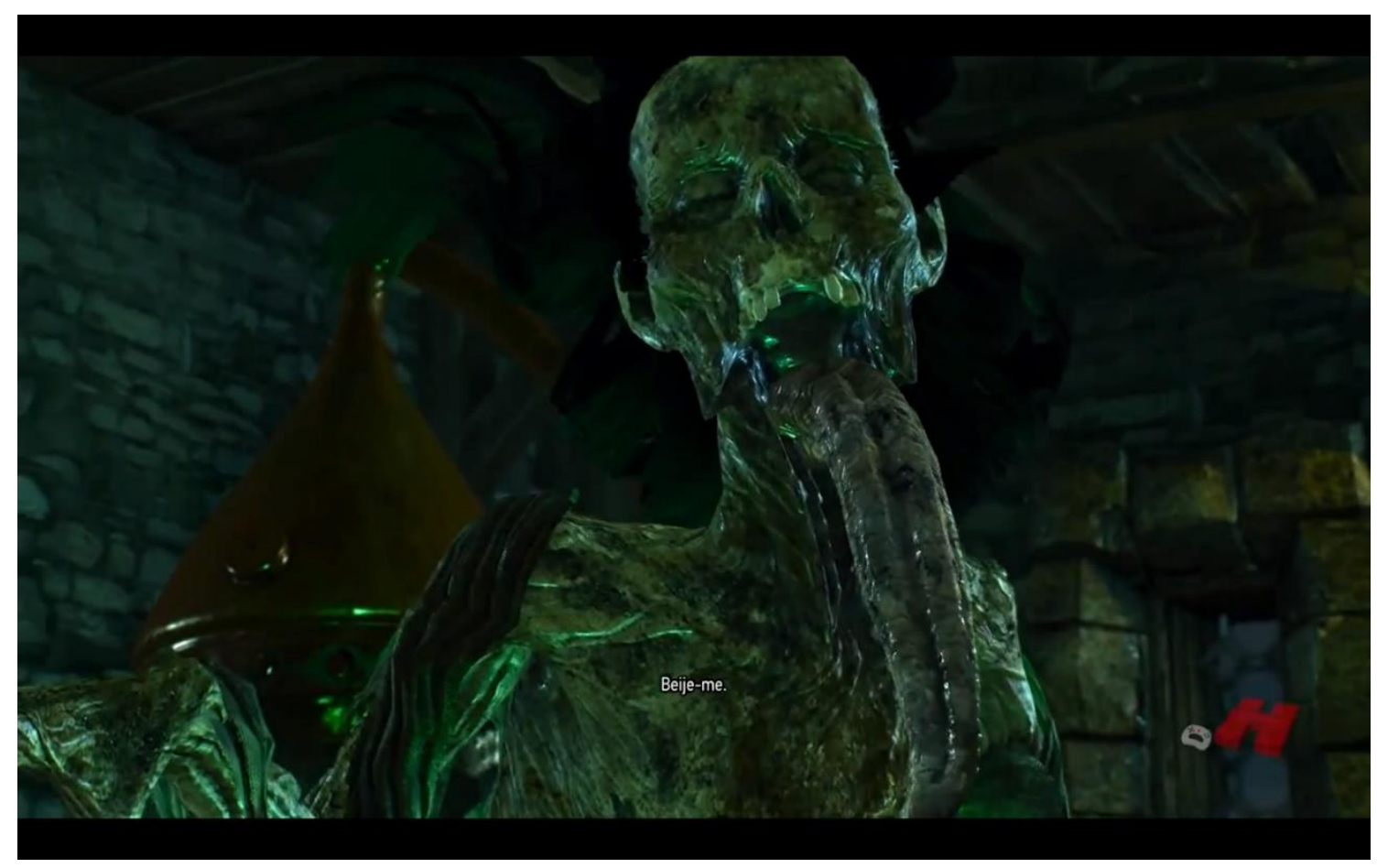

(Figura 3.34 - A dama da peste pede a Graham que a beije.) 


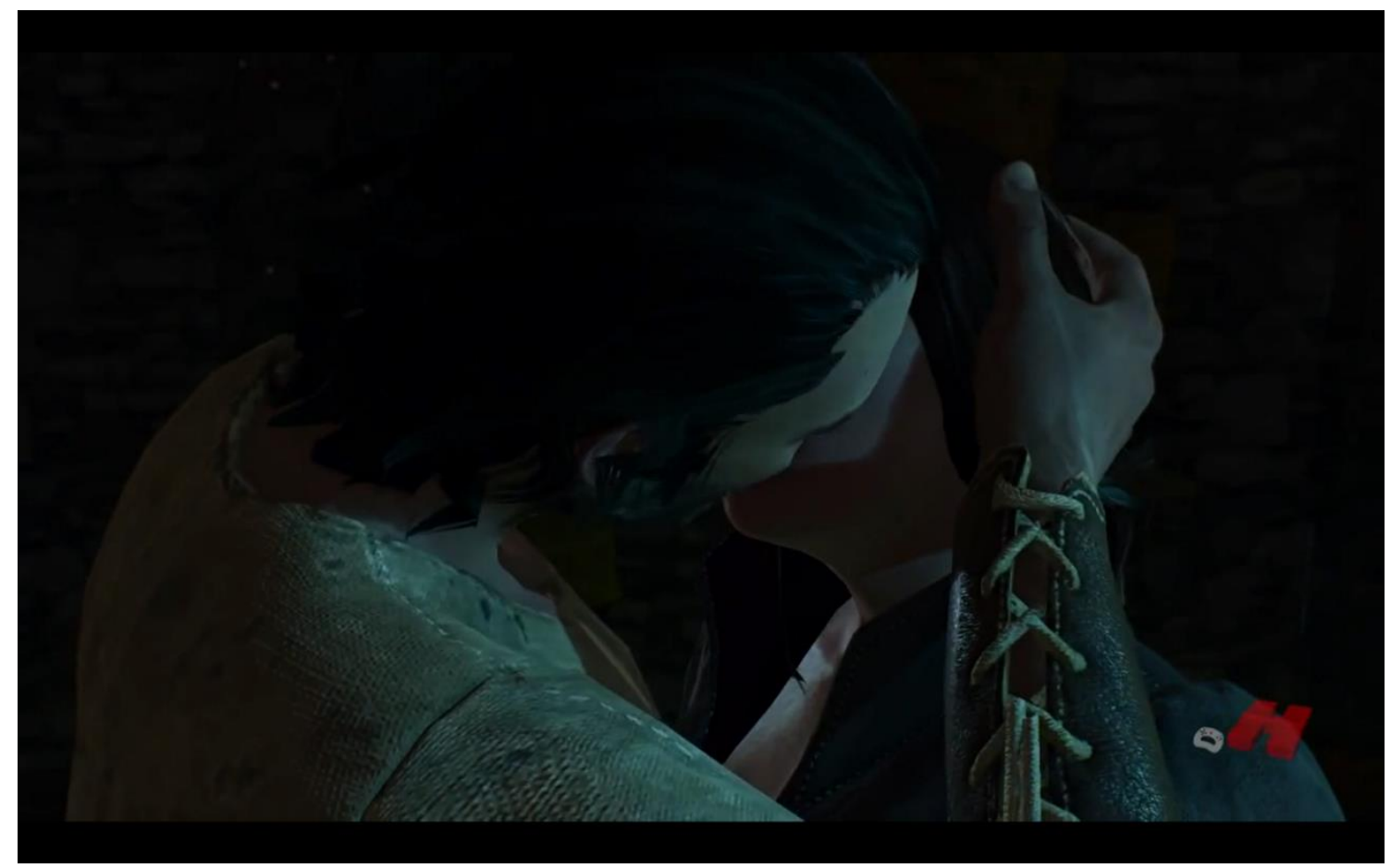

(Figura 3.35 - O rapaz beija a monstruosidade e quebra a maldição.)

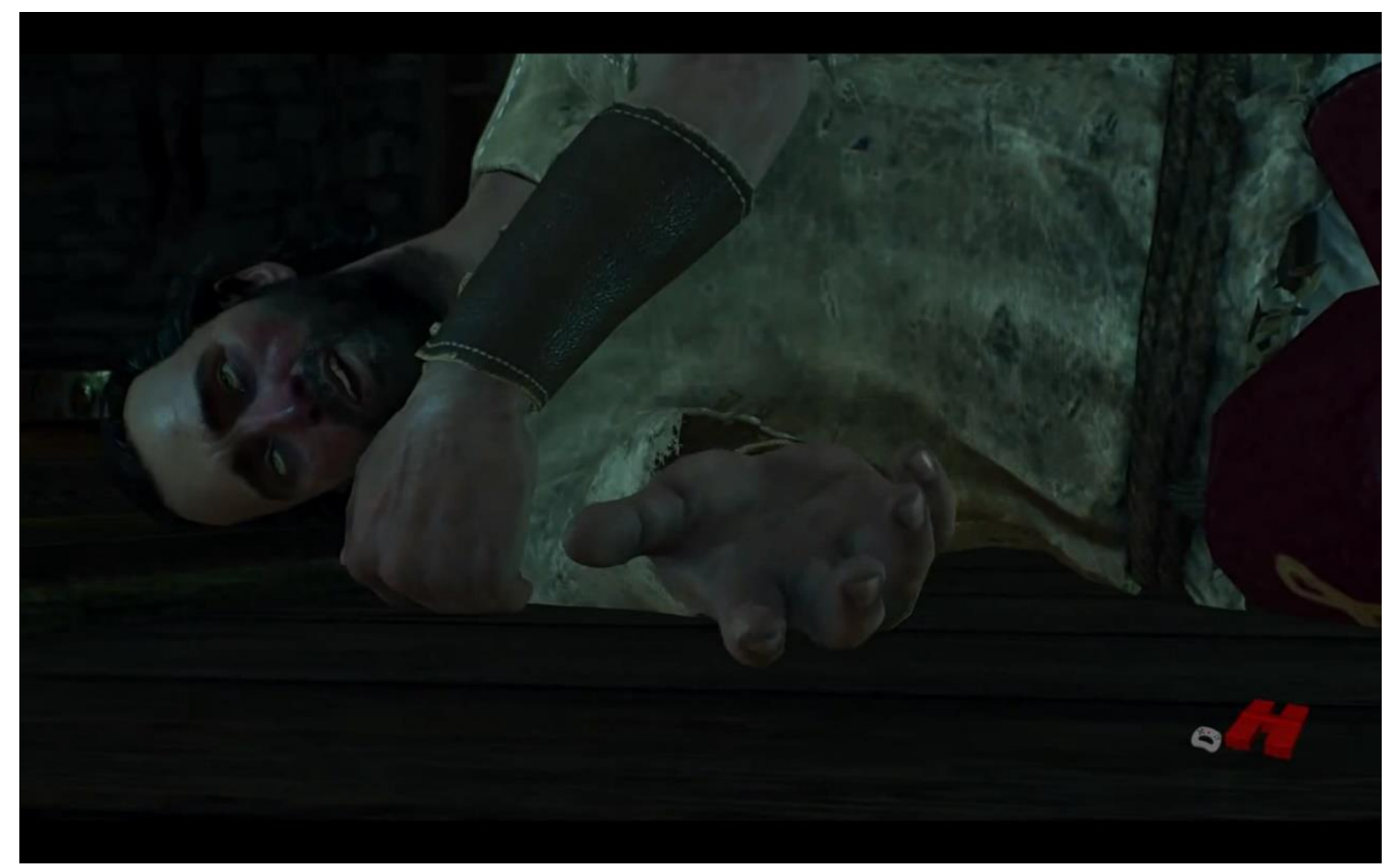

(Figura 3.36 - Graham morre logo após o beijo.)

Após sucinta descrição do episódio presente no jogo, podemos dizer que, intertextualmente, "Uma torre repleta de ratazanas" é uma estilização de "A bela adormecida no bosque". Segundo Norma Discini: 
Na estilização (...), há uma captação do texto-base; captação fundamental, narrativa e discursiva. Acreditamos, então, que usar o discurso de um outro como o discurso de um outro é captar-lhe as estruturas fundamentais, narrativas e discursivas. Mas, e aquela leve sombra lançada, o que seria?

Quanto à estilização, essa leve sombra constitui, em princípio, a transfiguração do textobase, e aí está a sua diferença em relação à paráfrase. Transfiguração enquanto transformação de figuras, que preenchem os mesmos percursos temáticos do texto-base, acrescentando-lhes outros. Mas transfiguração, essencialmente, como recriação. (DISCINI, 2004, p. 66).

Geralt busca um saber ao navegar para a ilha amaldiçoada. Ao encontrar o espectro atormentado, dá-se origem a um novo programa narrativo, o de Anabelle. A garota assume o papel temático similar ao da princesa adormecida de Perrault, no entanto, no nível discursivo, a letargia culmina na morte da filha do lorde. Ainda assim, se analisarmos o nível fundamental, em Perrault temos a oposição /vida/ VS. /morte/, que se mantém em negação da vida, representada pelo sono de cem anos da princesa. Já em The Witcher III, ao beber a poção do sono, Anabelle entra em estado letárgico, negando a vida, e posteriormente é devorada por ratos, conjungindo com a morte. Ainda assim, pela aura de maldição da ilha, fica presa à monstruosidade da dama da peste, figura de uma mulher cadavérica, o que leva o sujeito à esfera da /não-morte/.

\section{Quadrado semiótico Anabelle}

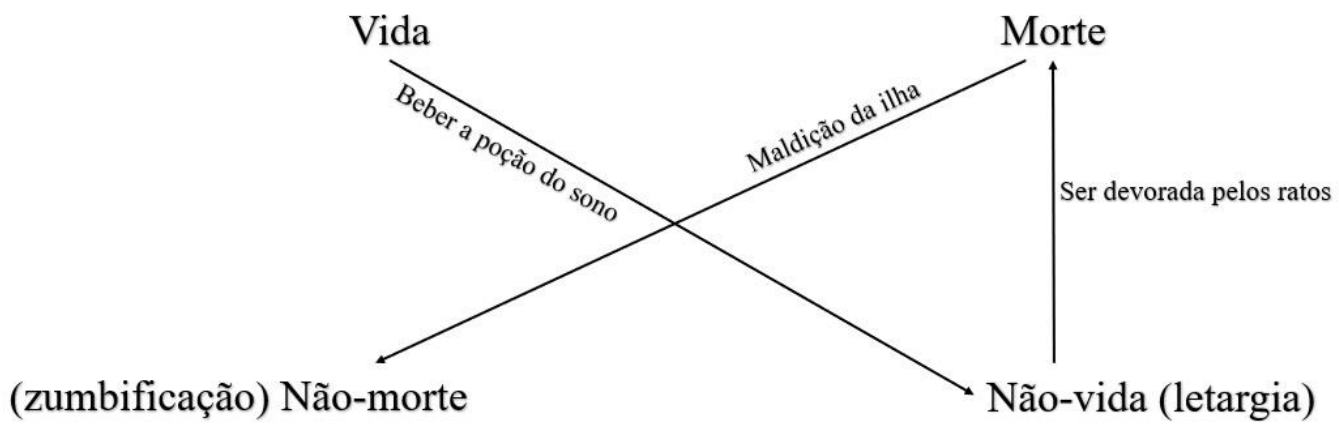

(Figura 3.37 - Quadrado semiótico do nível fundamental da história de Anabelle.) 
Mais detalhadamente ainda, podemos considerar que a maldição da ilha é o que prende Anabelle à sua forma monstruosa, da qual ela não tem poder por si de se libertar, o que também indicaria na narrativa de "Uma torre repleta de ratazanas" a oposição semântica /liberdade/ VS. /opressão/.

No PN de base, não tendo a competência para realizar sua performance, Geralt busca a solução em Graham. Neste momento, origina-se o PN de Graham, onde este vira o sujeito e Geralt passa a ser, além de seu destinador, o sujeito do fazer-fazer. O namorado de Anabelle, ao ser informado pelo protagonista do jogo sobre a situação, passa a dispor de um saber e o poder para quebrar a maldição (representado pela figura do beijo de amor verdadeiro). Dessa forma, podemos representar o nível narrativo assim:

\section{Programa narrativo de base}

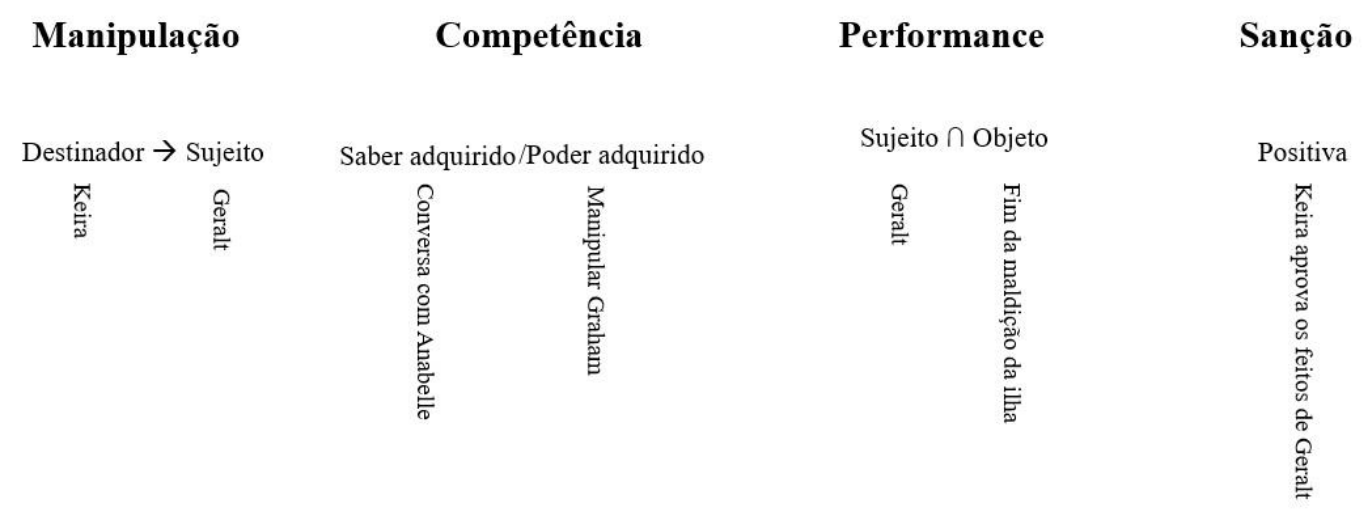

(Figura 3.38 - PN de base de "Uma torre repleta de ratazanas".) 


\section{Programa narrativo de Graham}

\begin{tabular}{|c|c|c|c|}
\hline Manipulação & Competência & Performance & Sanção \\
\hline Destinador $\rightarrow$ Sujeito & Saber adquirido/Poder inerente & Sujeito $\cap$ Objeto & Positiva \\
\hline 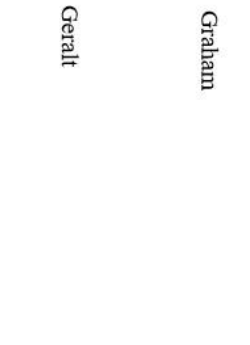 & 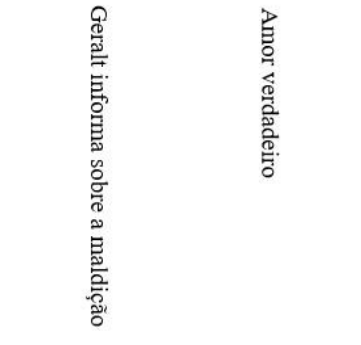 & 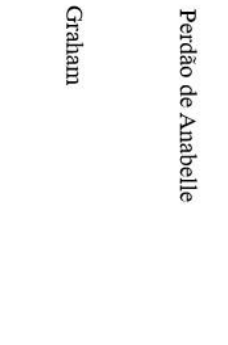 & 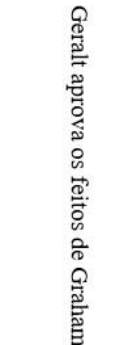 \\
\hline
\end{tabular}

(Figura 3.39 - Programa narrativo de Graham.)

Para considerarmos o nível discursivo da missão "Uma torre repleta de ratazanas", utilizaremos de outra tabela, agora já comparando as figuras do texto-base com as presentes na variante.

\begin{tabular}{|c|c|c|}
\hline & $\begin{array}{c}\text { "A bela adormecida no } \\
\text { bosque" }\end{array}$ & $\begin{array}{l}\text { "Uma torre repleta de } \\
\text { ratazanas" }\end{array}$ \\
\hline Temas & Figuras & Figuras \\
\hline Épico & $\begin{array}{c}\text { Castelo, príncipe, } \\
\text { princesa, serviçais, fada, } \\
\text { floresta, maldição, casa de } \\
\text { campo, fuso }\end{array}$ & $\begin{array}{c}\text { Castelo, lorde, filha do } \\
\text { lorde, mago, guerreiro, } \\
\text { feiticeira, espadas, torre, } \\
\text { paliçada, plebe, maldição, } \\
\text { poção do sono }\end{array}$ \\
\hline Amor & $\begin{array}{c}\text { Beijo de amor } \\
\text { verdadeiro, casamento, } \\
\text { amor parental }\end{array}$ & $\begin{array}{l}\text { Beijo de amor } \\
\text { verdadeiro }\end{array}$ \\
\hline Violência & Maldição & $\begin{array}{l}\text { Maldição, corpos, } \\
\text { monstros, sangue, } \\
\text { destroços }\end{array}$ \\
\hline
\end{tabular}

(Tabela 2 - Tabela com a comparação entre os temas e figuras dos textos, enfatizando as figuras em comum. Autoria própria) 
Nota-se que, apesar de a missão do jogo conter muito mais figuras de violência, afinal, é um RPG de ação, em que há combate por natureza, as figuras do cenário épico são semelhantes e a presença do beijo de amor verdadeiro para desfazer uma maldição se dá nas duas narrativas, porém, o final feliz se dá de maneira invertida em The Witcher III. Em Perrault, a princesa volta à vida graças ao beijo de amor verdadeiro e, junto ao príncipe, retornam para o reino. Após conflito com a rainha, o casal consegue permanecer unido. Na narrativa apresentada pelo jogo eletrônico, Anabelle já morreu, o que indica que a união do casal só pode se dar pelo falecimento de Graham, que ocorre devido ao beijo de amor verdadeiro, configurando um "felizes para sempre" no post mortem.

\subsubsection{O "deus" charlatão}

No Velho Testamento, a figura do sacrifício (ou oferta) a Deus é bastante recorrente, seja para agradecê-lo por uma benção alcançada, seja para implorar o perdão pela transgressão da Sua lei, ou mesmo por simplesmente demonstrar o afeto por Ele.

Em certos momentos do texto, a oferta é espontânea, enquanto em outros, como registrado no episódio de Abraão e Isaque, é o próprio Deus que requer o sacrifício para ser louvado.

E aconteceu depois destas coisas, que tentou Deus a Abraão, e disse-lhe: Abraão! E ele disse: Eis-me aqui.

E disse: Toma agora o teu filho, o teu único filho, Isaque, a quem amas, e vai-te à terra de Moriá, e oferece-o ali em holocausto sobre uma das montanhas que eu te direi.

E vieram ao lugar que Deus lhe dissera, e edificou Abraão ali um altar, e pôs em ordem a lenha, e amarrou a Isaque seu filho, e deitou-o sobre o altar em cima da lenha.

E estendeu Abraão a sua mão, e tomou o cutelo para imolar o seu filho;

Mas o anjo do Senhor lhe bradou desde os céus, e disse: Abraão, Abraão! E ele disse: Eisme aqui.

Então disse: Não estendas a tua mão sobre o moço, e não lhe faças nada; porquanto agora sei que temes a Deus e não me negaste o teu filho, o teu único. 
Então levantou Abraão os seus olhos, e olhou, e eis um carneiro detrás dele, travado pelas suas pontas num mato; e foi Abraão, e tomou o carneiro, e ofereceu-o em holocausto, em lugar de seu filho. (Gênesis, 22: 1-13)

Há uma relação de intertextualidade entre os episódios de sacrifícios presentes na cultura judaico-cristã e a missão "Um deus ganancioso" de The witcher III. Como a variante intertextual se refere a um conjunto de textos-base e não especificamente a um só, tomamos a decisão metodológica de nos apoiarmos no primeiro episódio que narra ofertas a Deus no Velho Testamento, registrado no quarto capítulo do livro de Gênesis. Nele temos:

E conheceu Adão a Eva, sua mulher, e ela concebeu, e teve a Caim, e disse: Alcancei do Senhor um varão.

E teve mais a seu irmão Abel; e Abel foi pastor de ovelhas, e Caim foi lavrador da terra.

E aconteceu, ao cabo de dias, que Caim trouxe do fruto da terra uma oferta ao Senhor.

E Abel também trouxe dos primogênitos das suas ovelhas e da sua gordura. E atentou o Senhor para Abel e para a sua oferta.

Mas para Caim e para a sua oferta não atentou. E irou-se Caim fortemente, e descaiu-lhe o semblante.

E o Senhor disse a Caim: Por que te iraste? E por que descaiu o teu semblante?

Se bem fizeres, não haverá aceitação para ti? E, se não fizeres bem, o pecado jaz à porta, e para ti será o seu desejo, e sobre ele dominarás. (Gênesis, 4:1-7)

O que temos aqui são dois PNs distintos, um em que Caim é o sujeito e outro em que Abel exerce esta função. Ambos querem ofertar a Deus, seu grande destinador, e tanto um como o outro sabe e pode fazê-lo. A performance se dá no momento em que as ofertas são feitas, descrita nos versículos terceiro e quarto. Entretanto, interpreta-se que a oferenda de Abel, aos olhos de Deus, era melhor do que a de Caim. 


\section{Programa narrativo de Caim}

\begin{tabular}{|c|c|c|c|}
\hline Manipulação & Competência & Performance & Sanção \\
\hline Destinador $\rightarrow$ Sujeito & Saber/Poder inerentes & Sujeito $\cap$ Objeto & Negativa \\
\hline 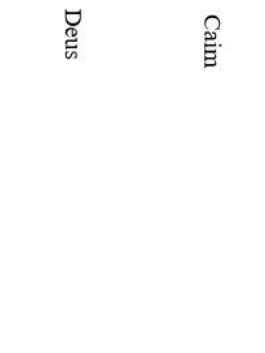 & 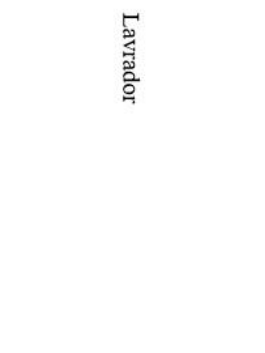 & 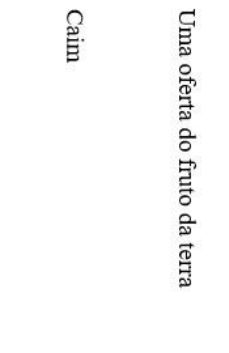 & 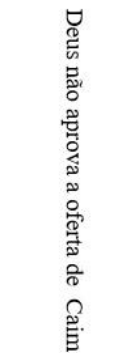 \\
\hline
\end{tabular}

(Figura 3.40 - Programa narrativo de Caim)

\section{Programa narrativo de Abel}

\begin{tabular}{|c|c|c|c|}
\hline Manipulação & Competência & Performance & Sanção \\
\hline Destinador $\rightarrow$ Sujeito & Saber/Poder inerentes & Sujeito $\cap$ Objeto & Positiva \\
\hline 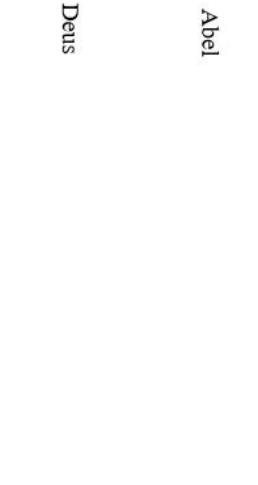 & 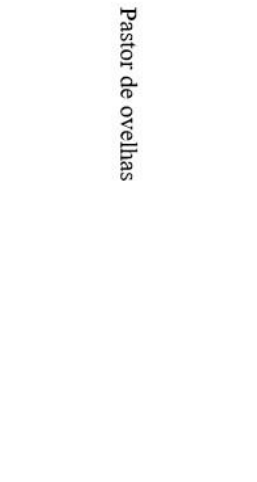 & 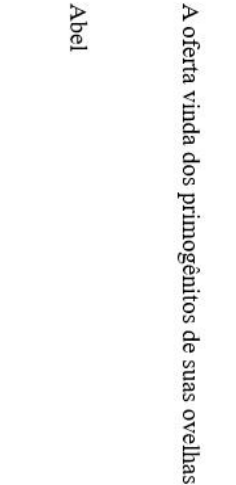 & 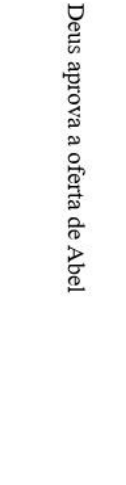 \\
\hline
\end{tabular}

(Figura 3.41 - Programa narrativo de Abel)

De acordo com o próprio texto, o segundo filho de Adão ofereceu "dos primogênitos das suas ovelhas e da sua gordura", dando-nos a entender que eram as maiores e mais desenvolvidas criaturas do seu gado, o melhor que podia entregar, enquanto Caim trouxe "uma oferta", o que nos leva a crer, pelo uso do artigo indefinido "uma", que tratava-se de um tipo qualquer dos produtos lavrados em sua terra. Desse modo, Deus sanciona positivamente a Abel e negativamente a Caim, e ainda antecipa ao primogênito de Adão que, pela sua reação de ira, o pecado o rondará e fará parte constante 
de sua vida, em uma espécie de maldição anunciada. O que se sucede, como se sabe, é que Caim, tomado pela fúria e pela inveja, consuma o primeiro homicídio, assassinando a Abel e carregando a marca do pecado consigo para sempre.

De modo alegórico, o capítulo quatro do livro de Gênesis nos demonstra que ao se ofertar algo para Deus, é necessário que seja o melhor, pois, se oferecido qualquer coisa indiferentemente, ser-lhe-á recusado e ainda correrá o risco de sofrer uma punição divina.

Apoiados nisso, abordamos a missão "Um deus ganancioso" de The Witcher III. Em meio às suas aventuras na terra sem lei de Velen, Geralt encontra dois camponeses discutindo em um terreno abandonado e resolve investigar. Ao conversar com a dupla, descobre que há um "deus supremo" na região, responsável por proteger o vilarejo local, mas que, ao contrário, tem anunciado maldições ao povo, por suas ofertas inadequadas.

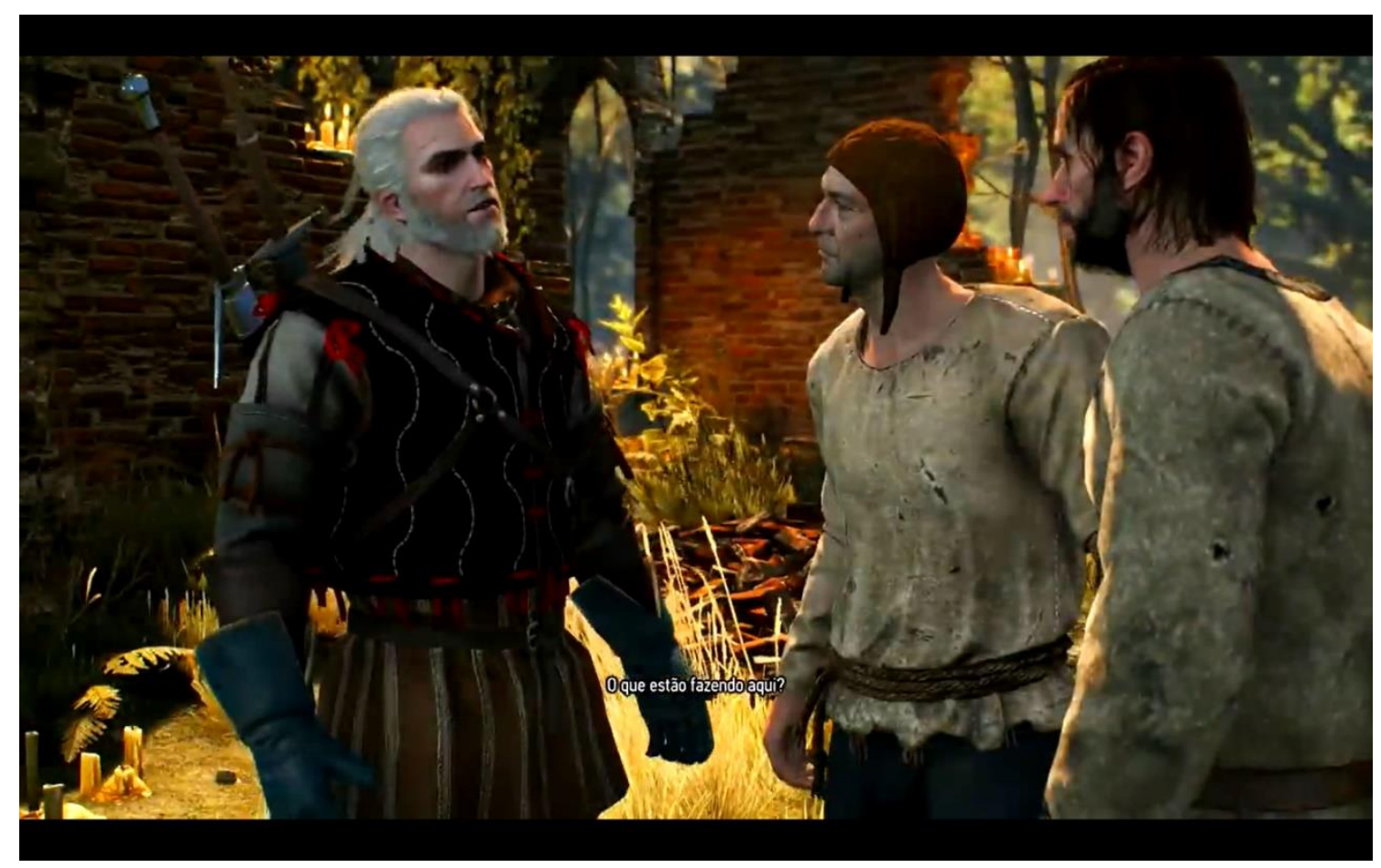

(Figura 3.42 - Geralt pergunta aos camponeses: "O que estão fazendo aqui?") 


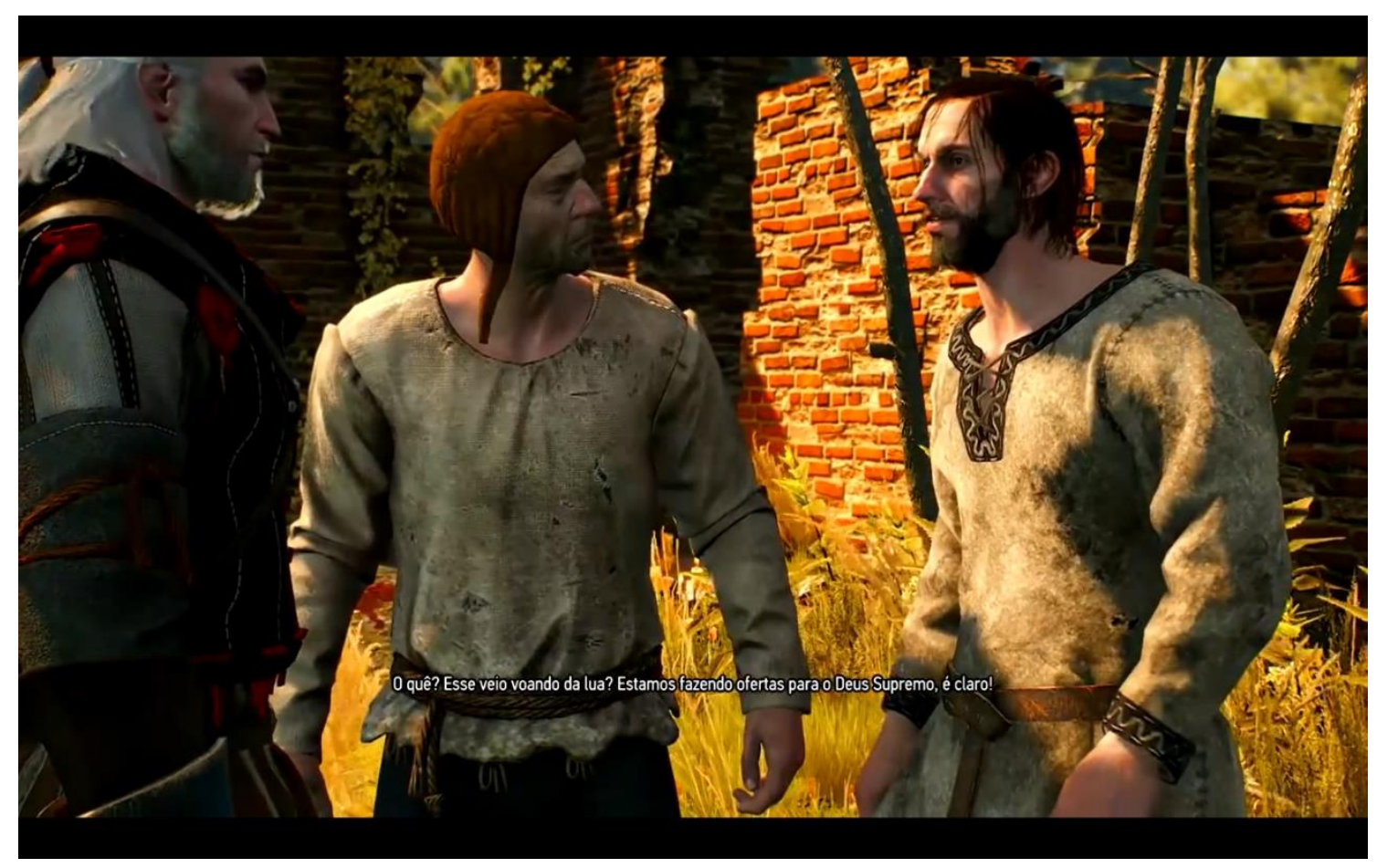

(Figura 3.43 - "O quê? Esse veio voando da lua? Estamos fazendo ofertas para o Deus Supremo, é claro!")

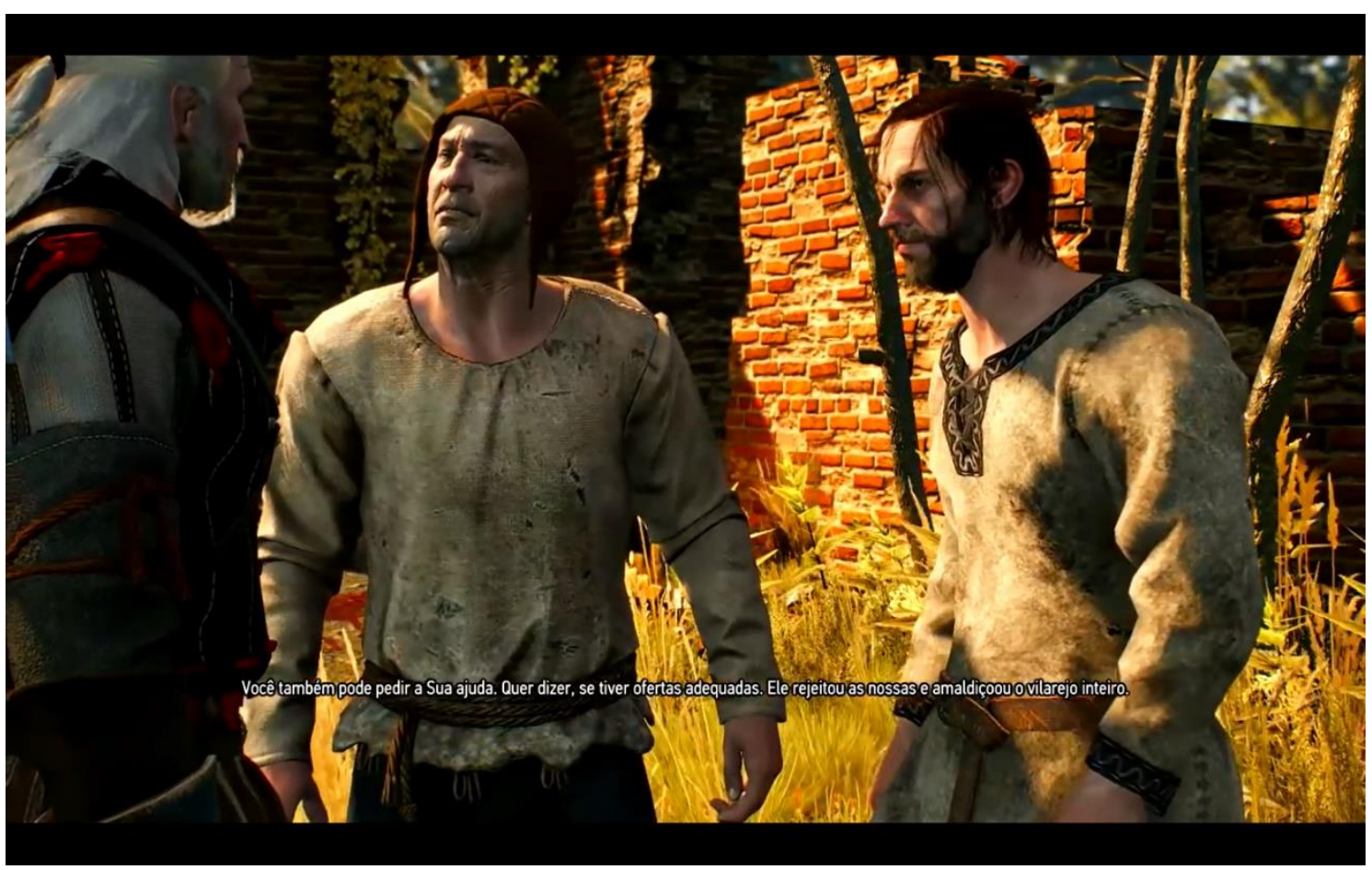

(Figura 3.44 - "Você também pode pedir a Sua ajuda. Quer dizer, se tiver ofertas adequadas. Ele rejeitou as nossas e amaldiçoou o vilarejo inteiro.")

Interessado na questão, o protagonista pede mais informações sobre a deidade e lhe é contado que o "deus supremo" surgiu quando um membro do vilarejo fora colher 
palha e testemunhara um arbusto pegar fogo, seguido de uma voz vinda do chão que exigira a entrega de oferendas e obediência. Intrigado, Geralt decide investigar mais.

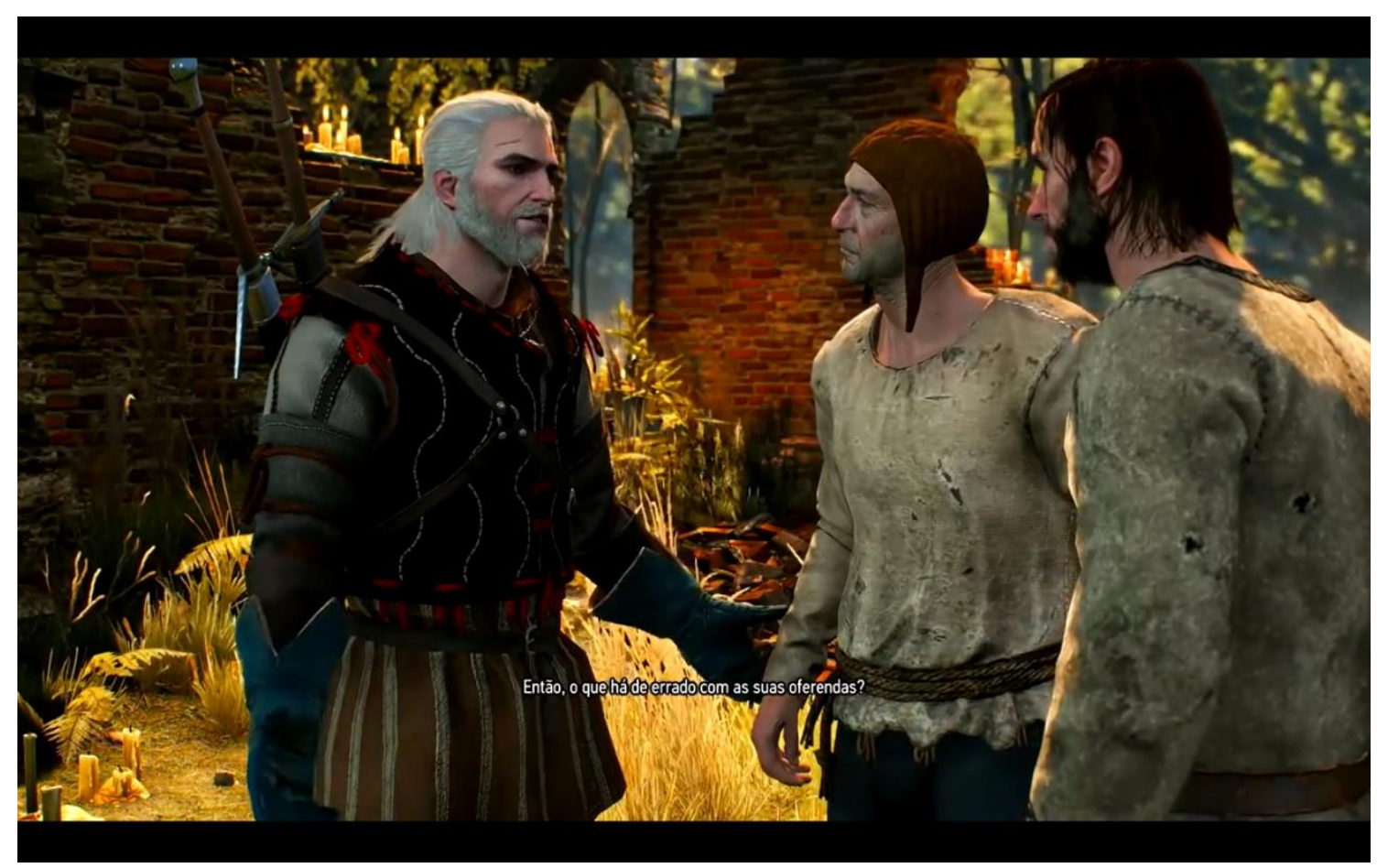

(Figura 3.45 - "Então, o que há de errado com as suas oferendas?")

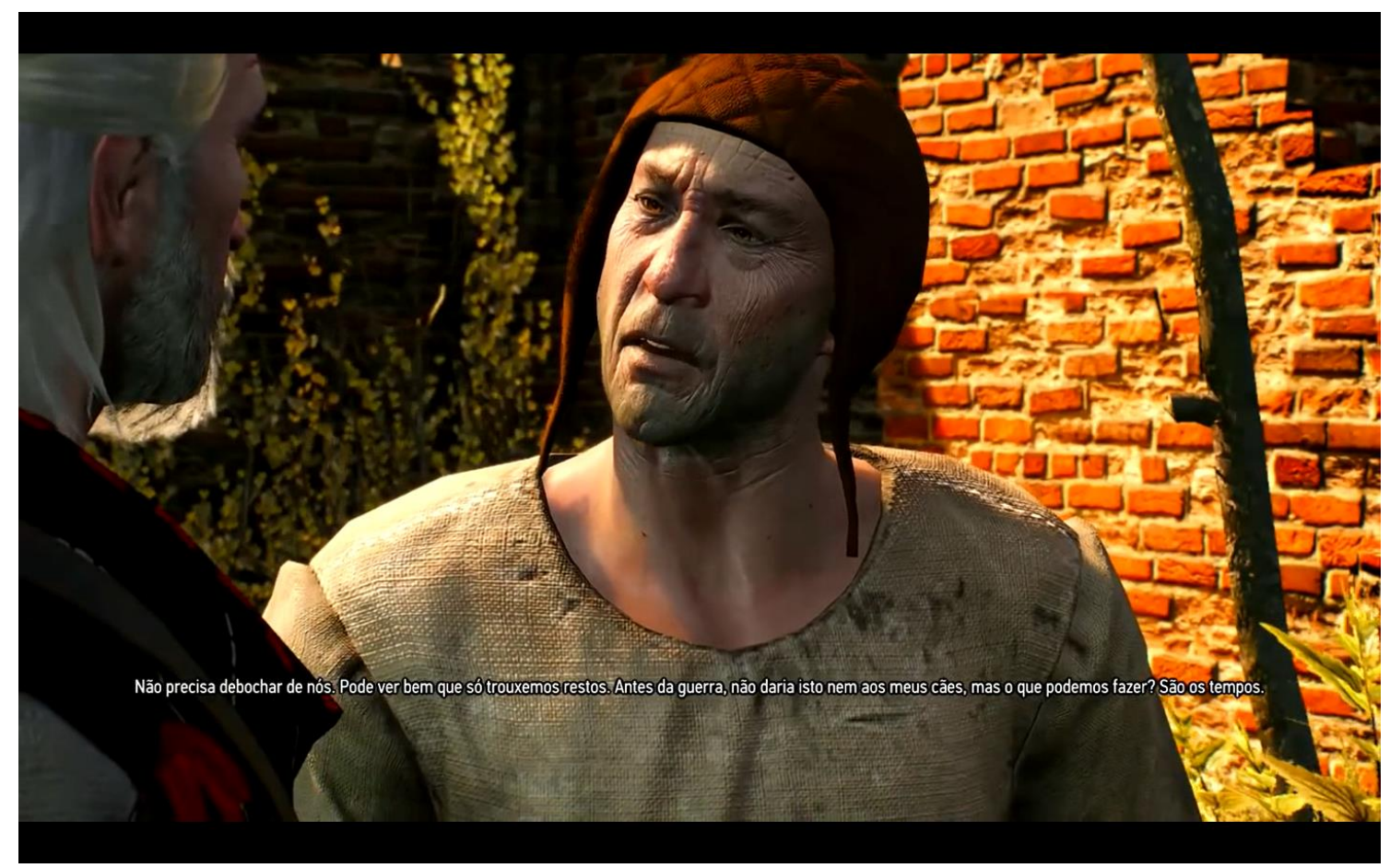

(Figura 3.46 - "Não precisa debochar de nós. Pode ver bem que só trouxemos restos. Antes da guerra, não daria isto nem aos meus cães, mas o que podemos fazer? São os tempos.") 


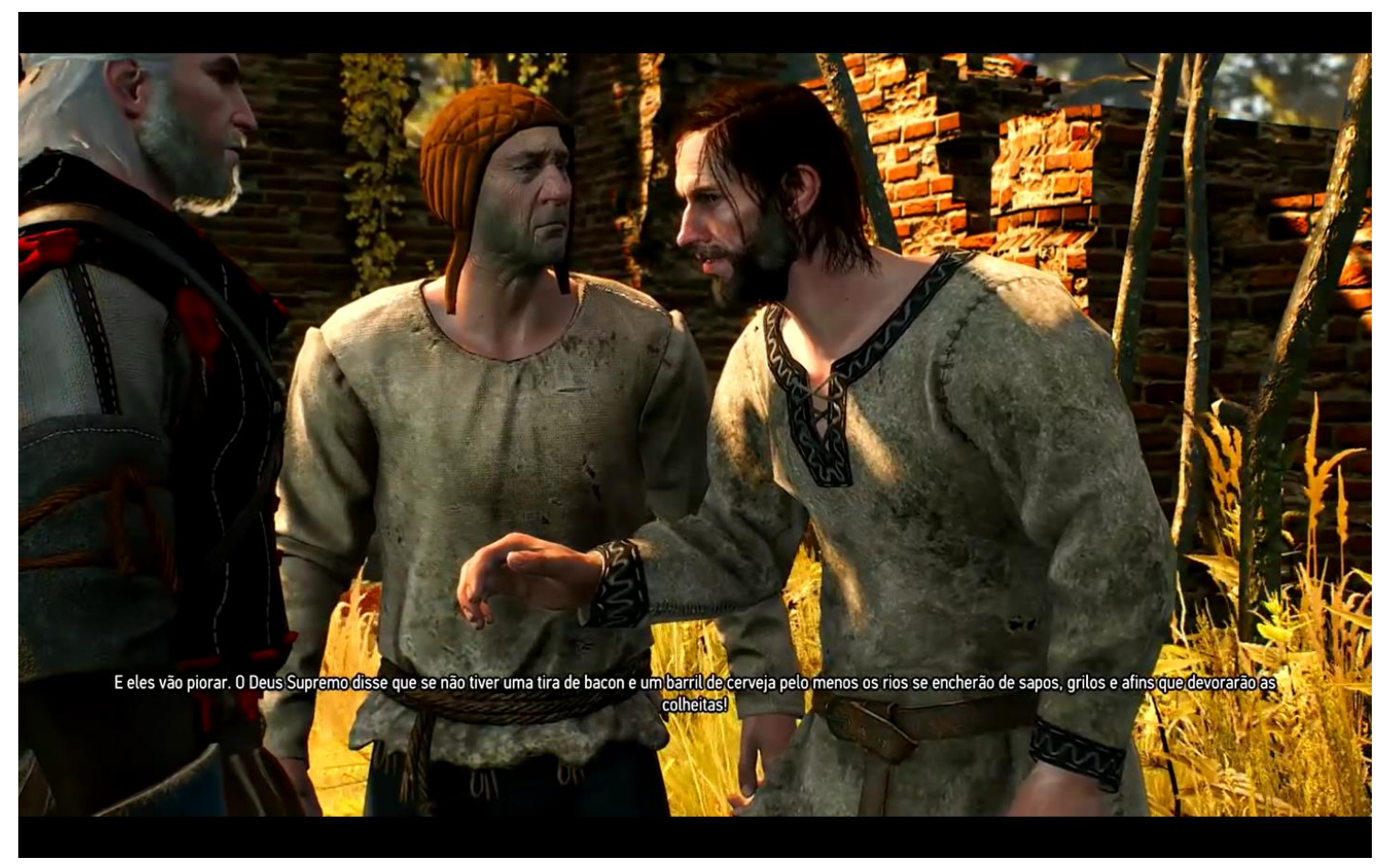

(Figura 3.47 - E eles vão piorar. O Deus Supremo disse que se não tiver uma tira de bacon e um barril de cerveja pelo menos, os rios se encherão de sapos, grilos e afins que devorarão as colheitas!")

Com o intuito de ajudar os camponeses, Geralt procura conversar com o "deus supremo", aproximando-se do altar e invocando-o. 


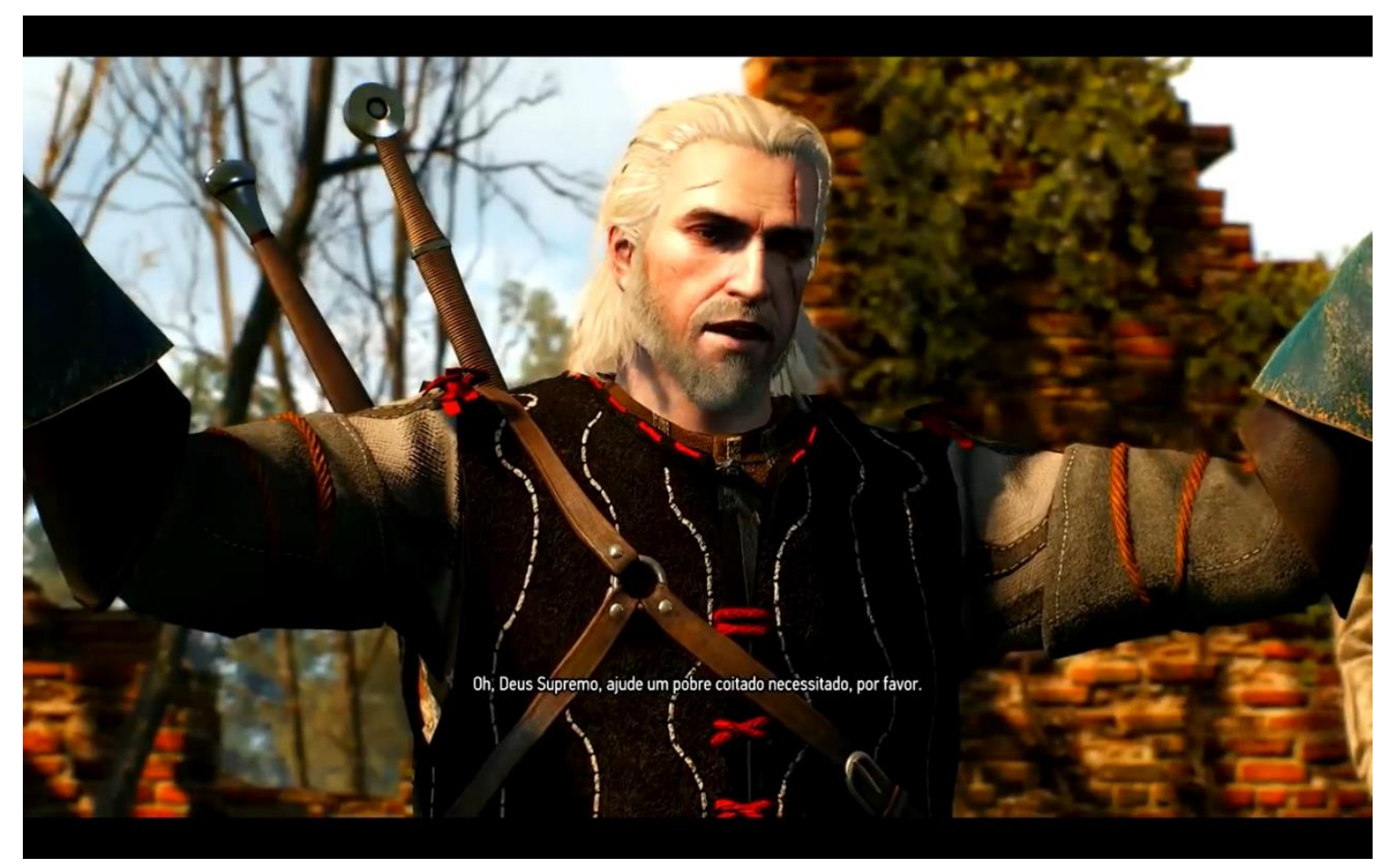

(Figura 3.48 - Geralt invoca ao deus dos camponeses: "Oh, Deus Supremo, ajude um pobre coitado necessitado, por favor.")

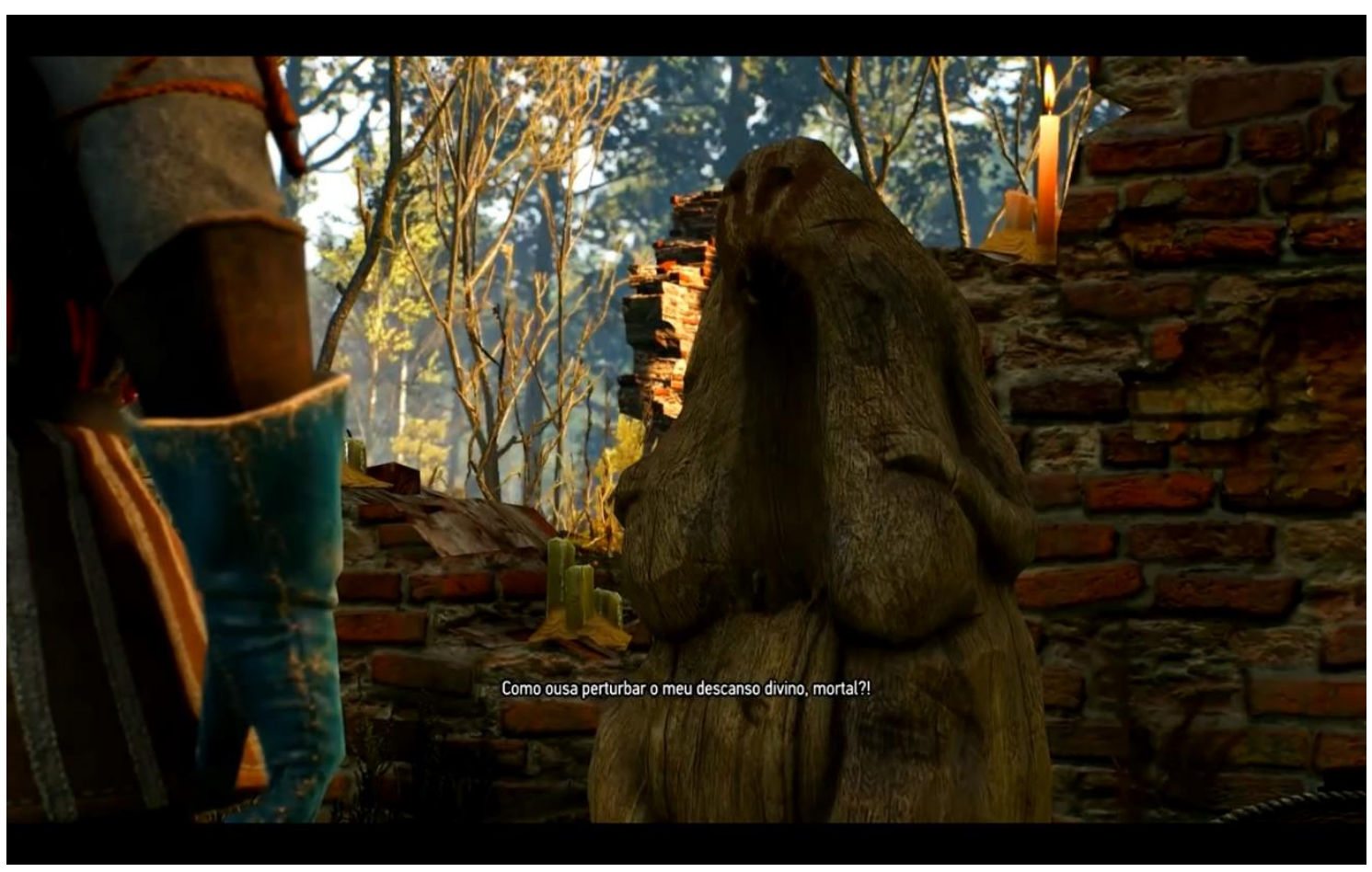

(Figura 3.49 - A voz abafada responde do altar: "Como ousa perturbar o meu descanso divino, mortal?!") 


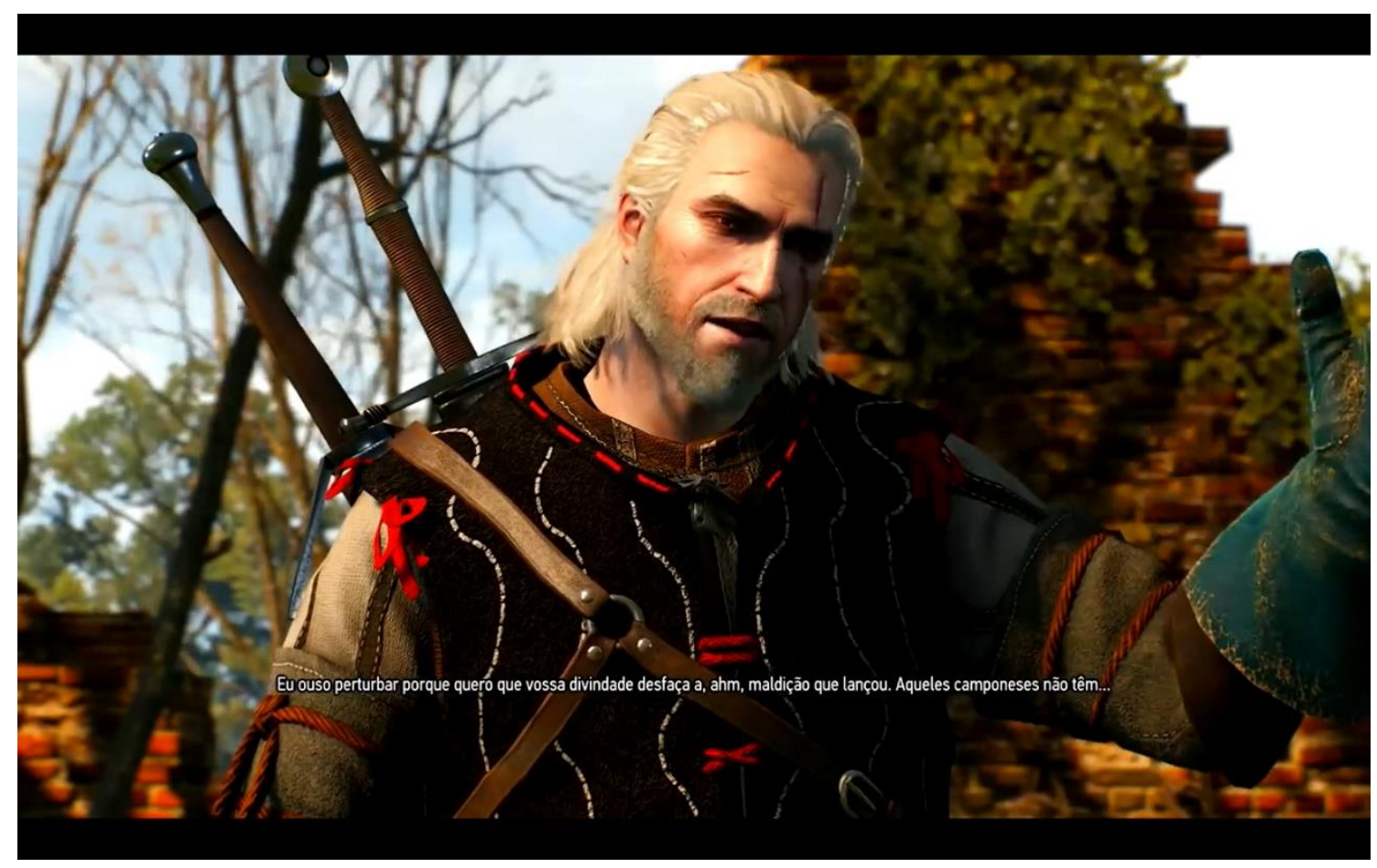

(Figura 3.50 - "Eu ouso perturbar porque quero que vossa divindade desfaça a, ahm, maldição que lançou. Aqueles camponeses não têm...")

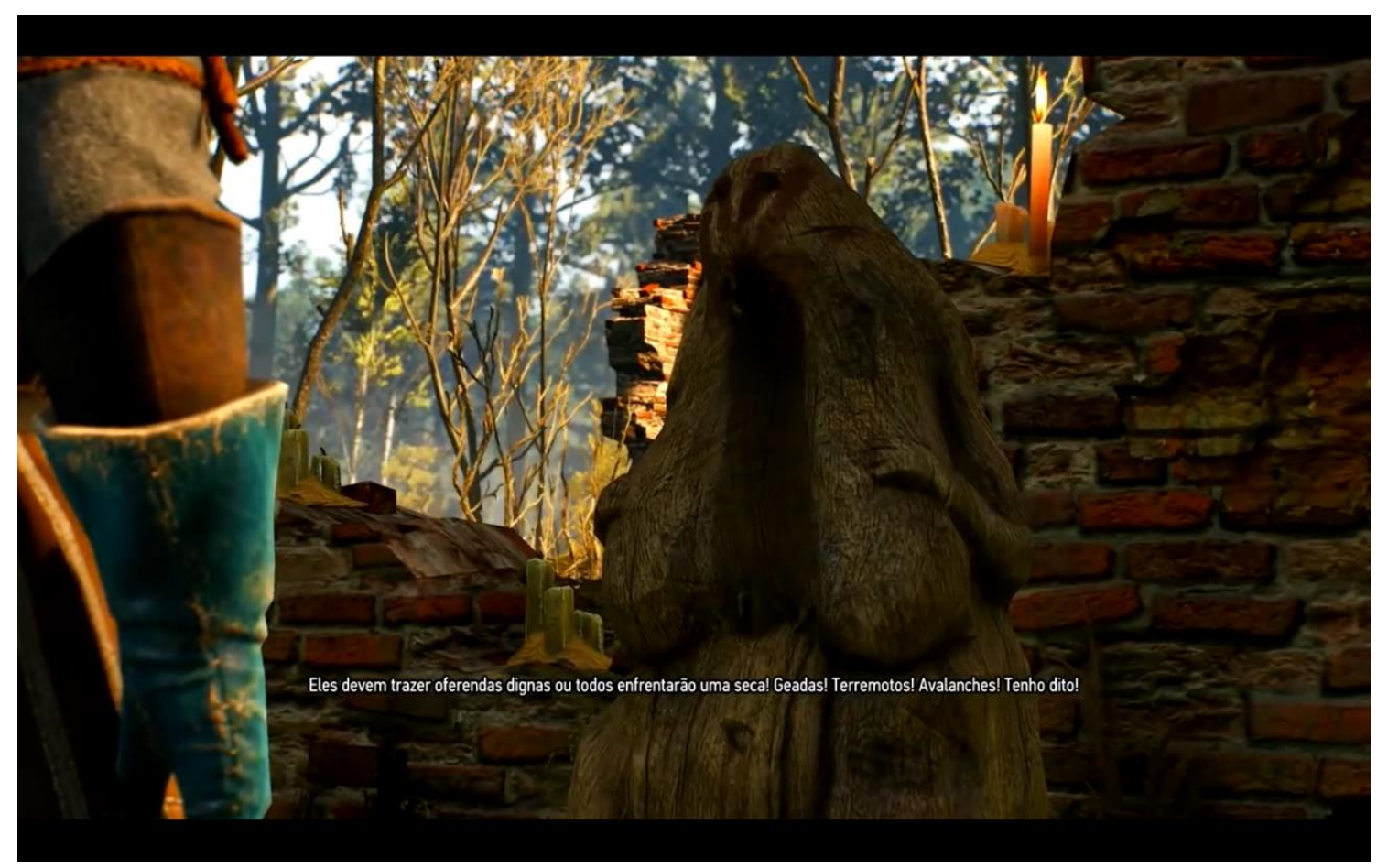

(Figura 3.51 - "Eles devem trazer oferendas dignas ou todos enfrentarão uma seca! Geadas! Terremotos! Avalanches! Tenho dito!")

Quando o "deus" menciona “avalanches”, Geralt desconfia, já que a terra de Velen não é marcada por terreno montanhoso. Com sua audição aguçada, o protagonista 
consegue supor que a voz da "divindade" vem do subsolo do terreno abandonado. Explorando os arredores, o guerreiro identifica uma ilusão mágica e a desfaz com um aparato que recebera anteriormente de sua amiga feiticeira, revelando uma escadaria para uma câmara escondida. Ao adentrar o ambiente, depara-se com uma figura um tanto curiosa.

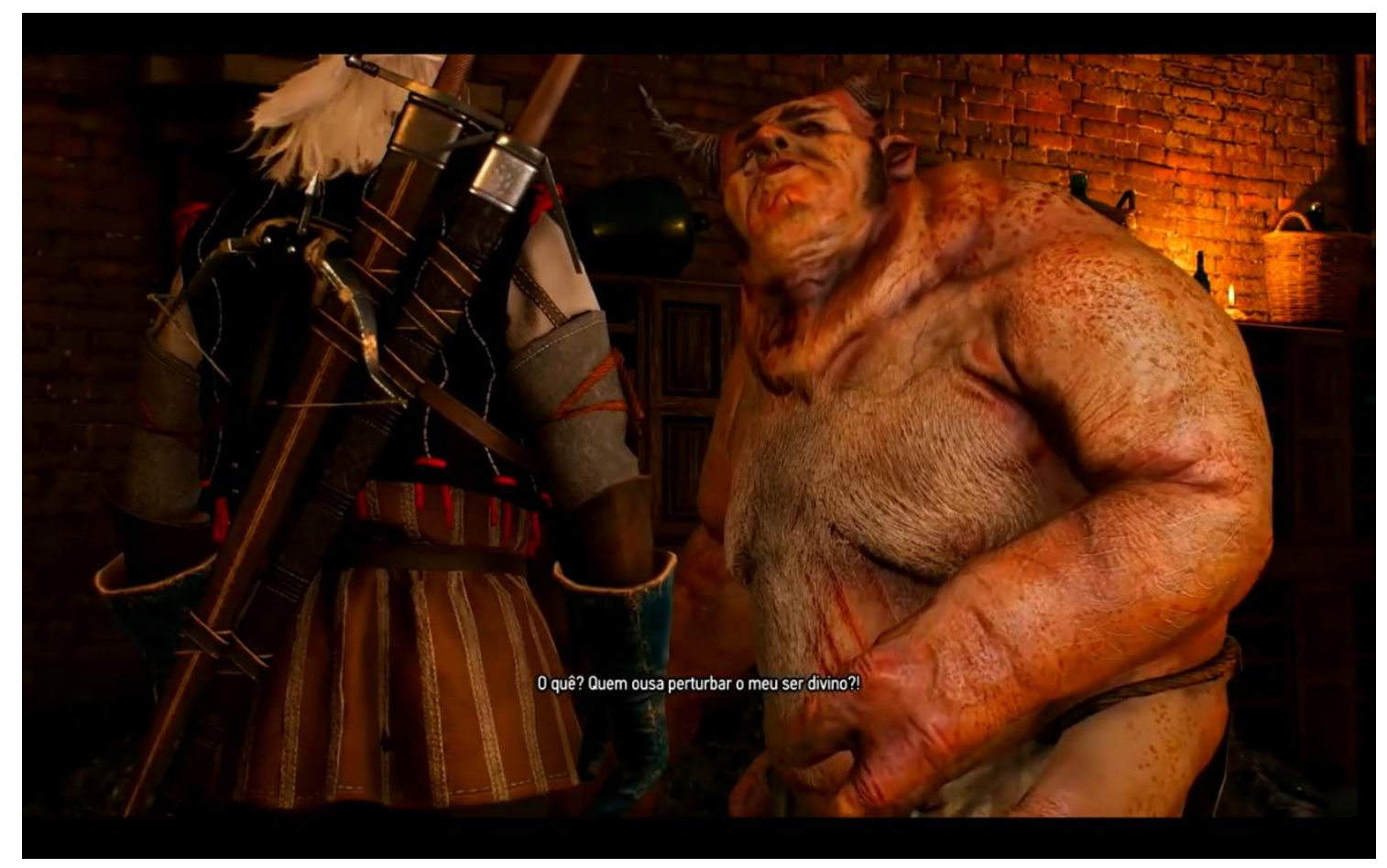

(Figura 3.52 - O monstro indaga: "O quê? Quem ousa perturbar o meu ser divino?!") 


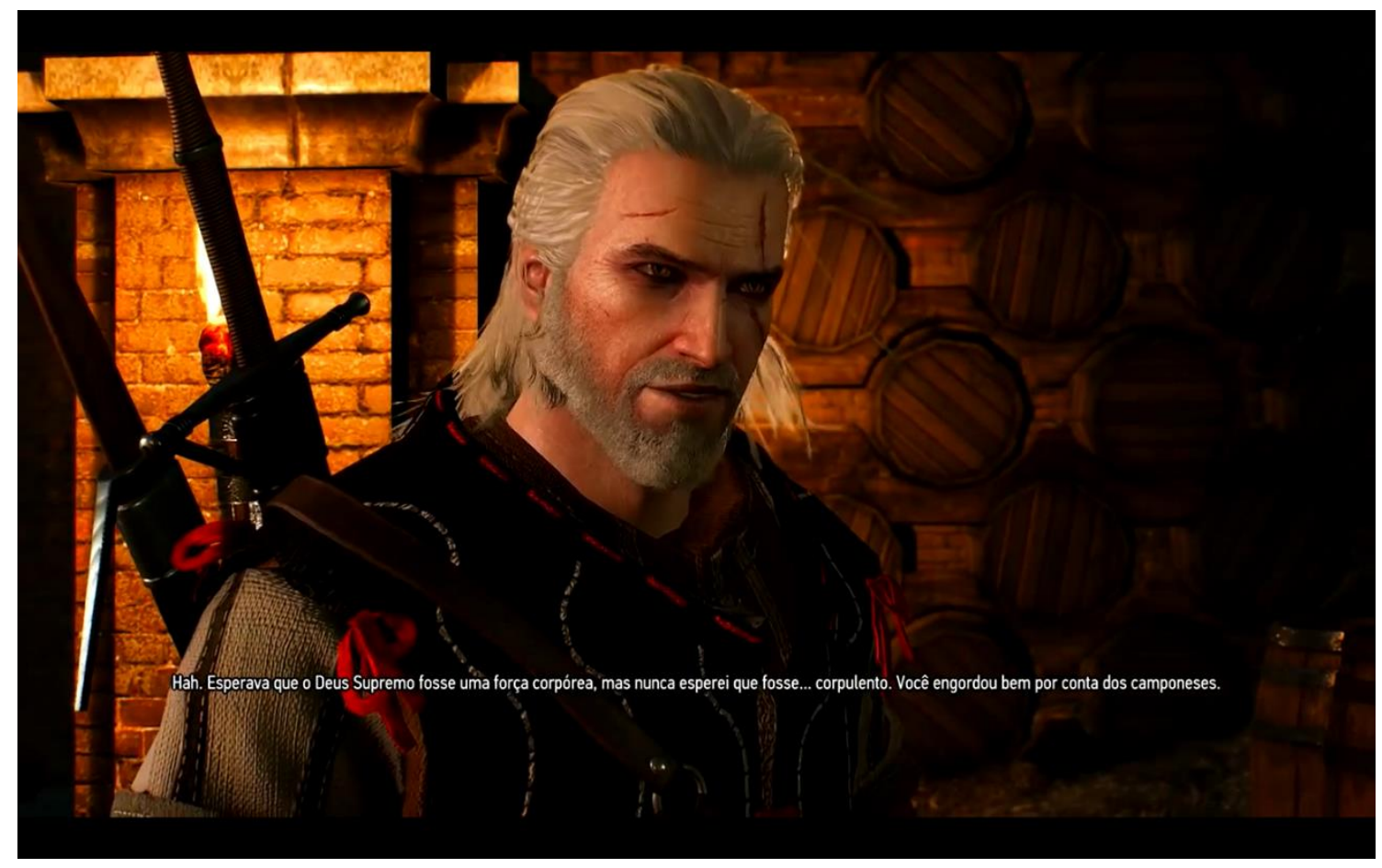

(Figura 3.53 - Geralt satiriza o porte da criatura: "Esperava que o Deus Supremo fosse uma força corpórea, mas nunca esperei que fosse... corpulento. Você engordou bem por conta dos camponeses.")

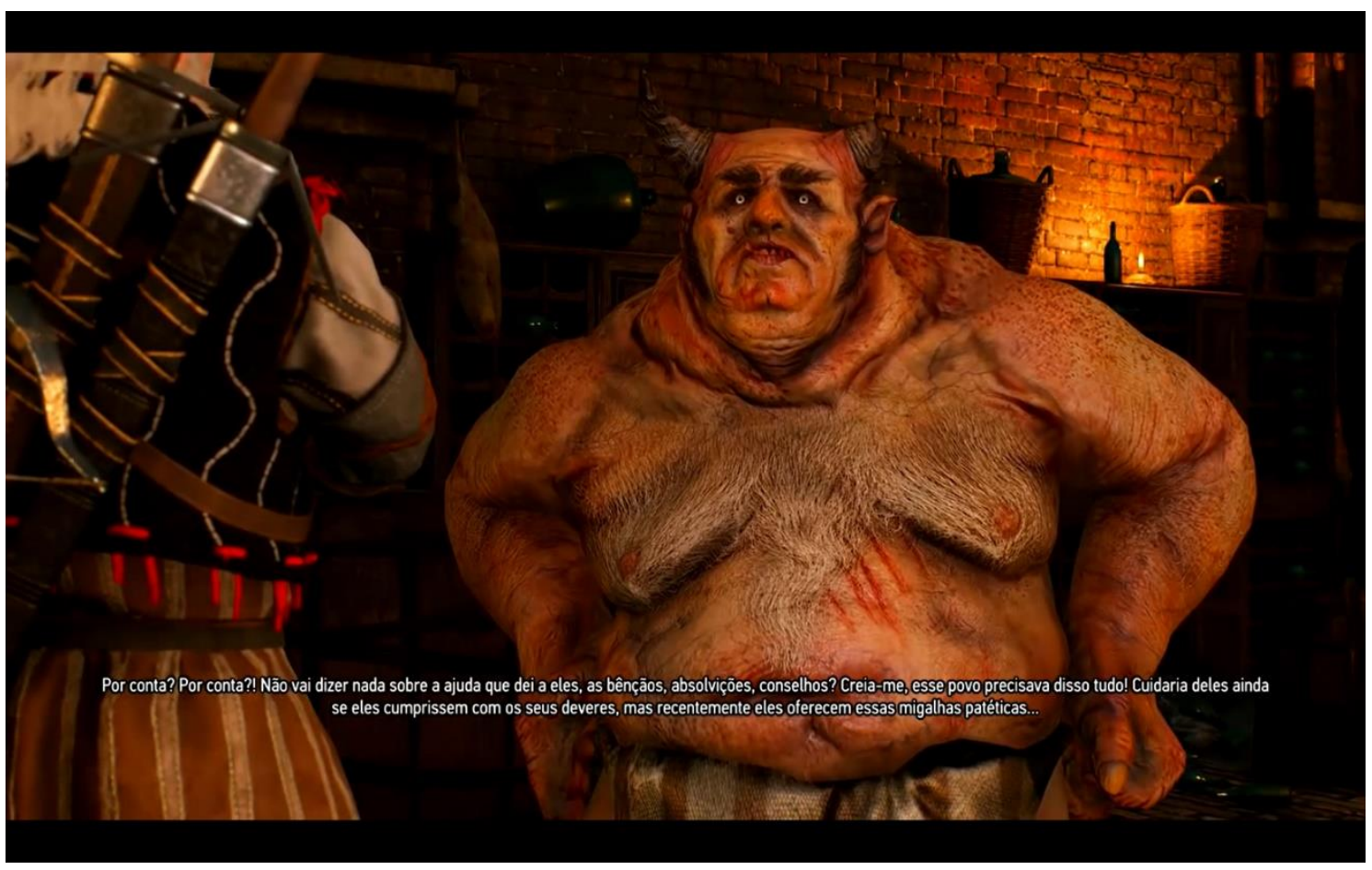

(Figura 3.54 - "Não vai dizer nada sobre a ajuda que dei a eles, as bençãos, absolvições, conselhos? Creiame, esse povo precisava disso tudo! Cuidaria deles ainda se eles cumprissem com os seus deveres, mas recentemente eles me oferecem essas migalhas patéticas...") 


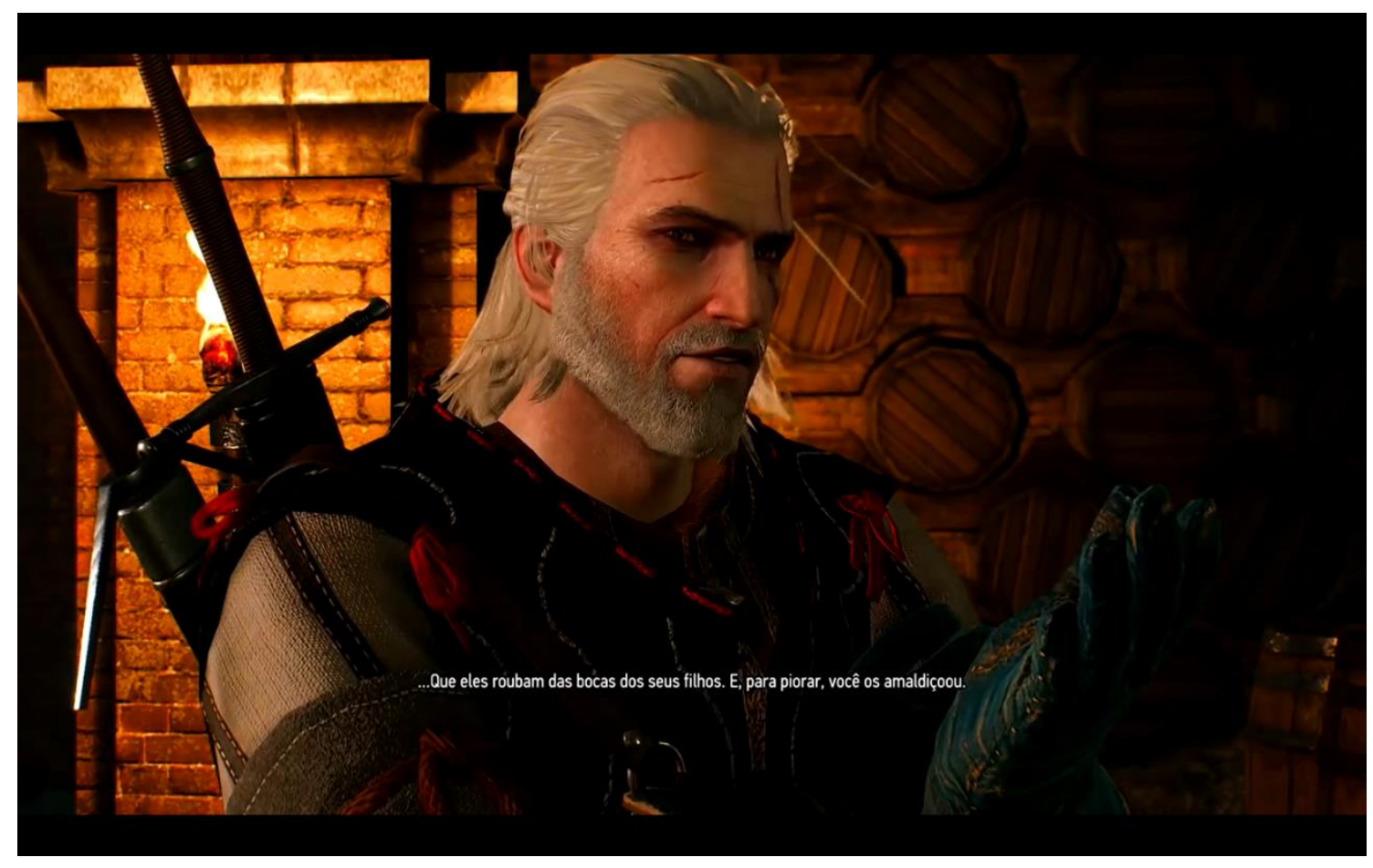

(Figura 3.55 - "...Que eles roubam das bocas dos seus filhos. E, para piorar, você os amaldiçoou.")

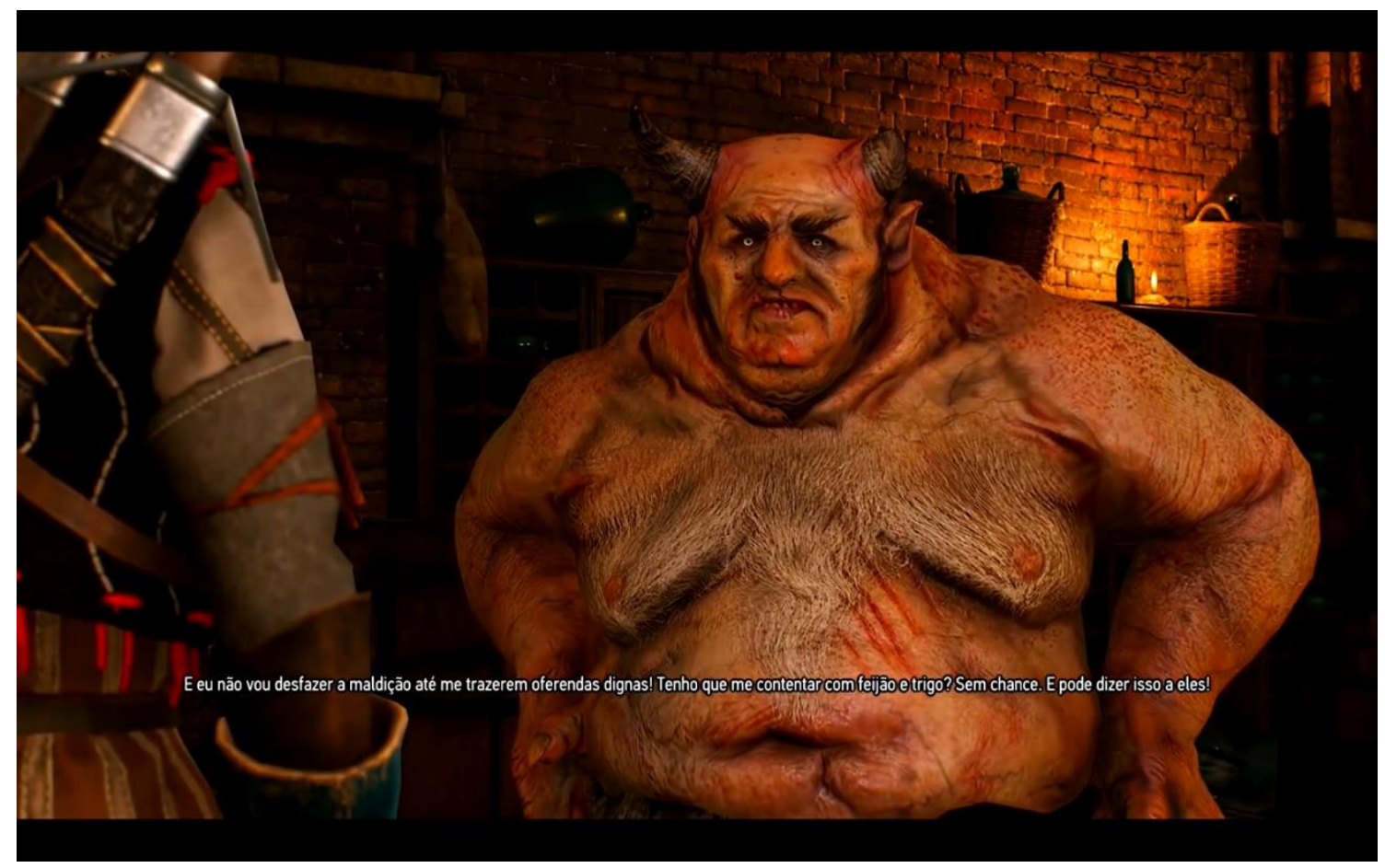

(Figura 3.56 - E eu não vou desfazer a maldição até me trazerem oferendas dignas! Tenho que me contentar com feijão e trigo? Sem chance. E pode dizer isso a eles!")

Após discussão, Geralt confronta o monstro e o mata. Solucionado o problema, o guerreiro decide informar aos camponeses sobre como o vilarejo inteiro estava sendo 
manipulado por um “deus" charlatão, no entanto, acaba surpreso com a reação da dupla que o aguardava.

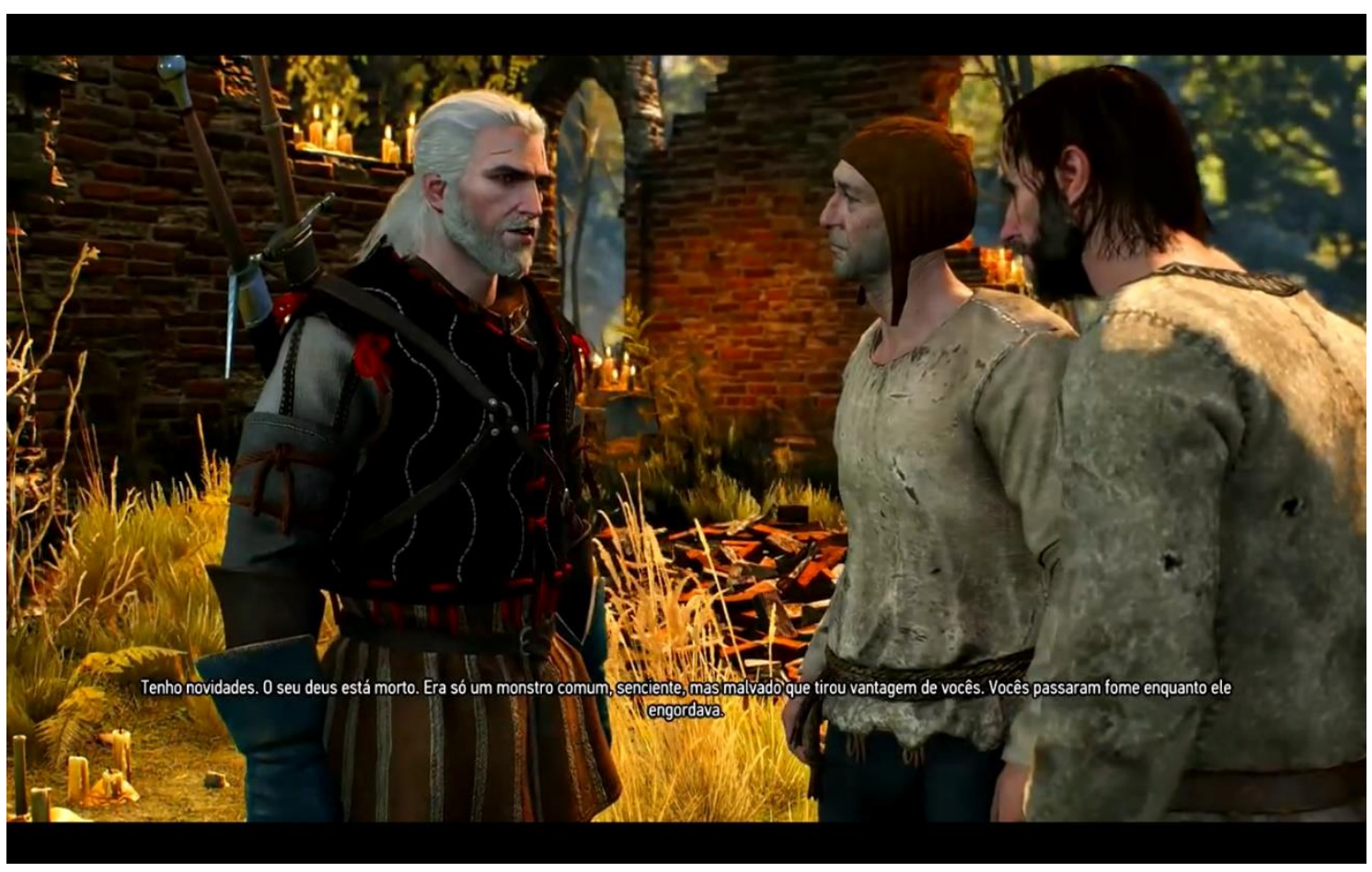

(Figura 3.57 - "Tenho novidades. O seu deus está morto. Era só um monstro comum senciente, mas malvado, que tirou vantagem de vocês. Vocês passaram fome enquanto ele engordava.") 


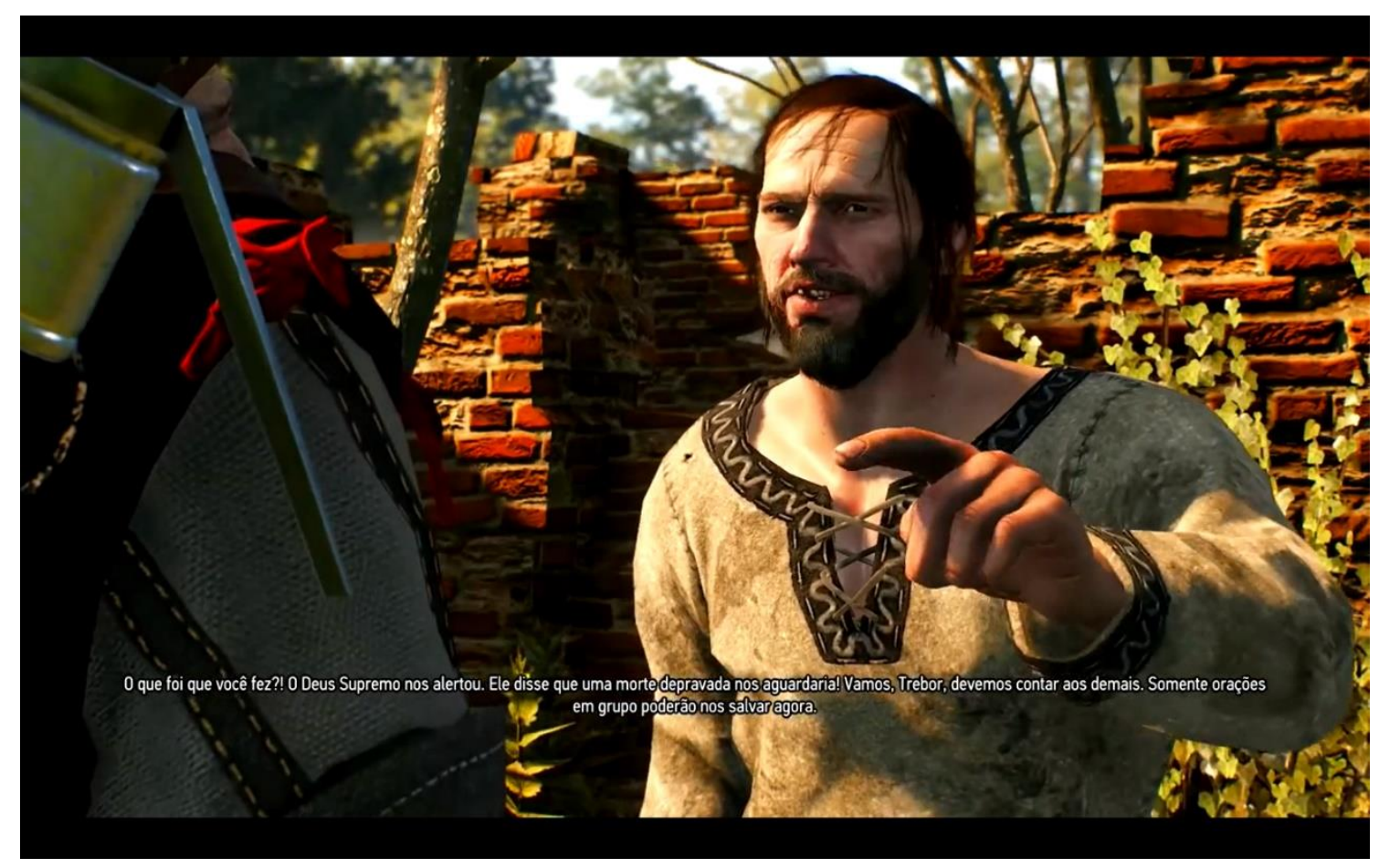

(Figura 3.58 - O camponês reage: "O que foi que você fez?! O Deus Supremo nos alertou. Ele disse que uma morte depravada nos aguardaria! Vamos, Trebor, devemos contar aos demais. Somente orações em grupo poderão nos salvar agora.")

"Um deus ganancioso" pode ser considerado um PN de uso, presente na narrativa de Geralt. No nível fundamental encontramos a oposição/vida/ VS. /morte/, de modo que o vilarejo passa fome, começando a entrar em um estado de /não-vida/.

Para tentar reverter a situação, o sujeito decide interceder pelo vilarejo. Geralt busca um saber ao conversar com o altar do "deus supremo" e o obtém ao identificar que a voz vem do subsolo e que há uma ilusão mágica impedindo que os camponeses enxerguem a escadaria que leva às ruínas onde o obeso monstro se esconde.

Ao dissipar a magia e confrontar a criatura, o sujeito realiza a performance, no entanto, de forma inesperada tanto para ele quanto para o jogador que comanda a ação, é sancionado negativamente, devido à ignorância daqueles que receberam sua ajuda. 


\section{Programa narrativo de "Um deus ganancioso"}
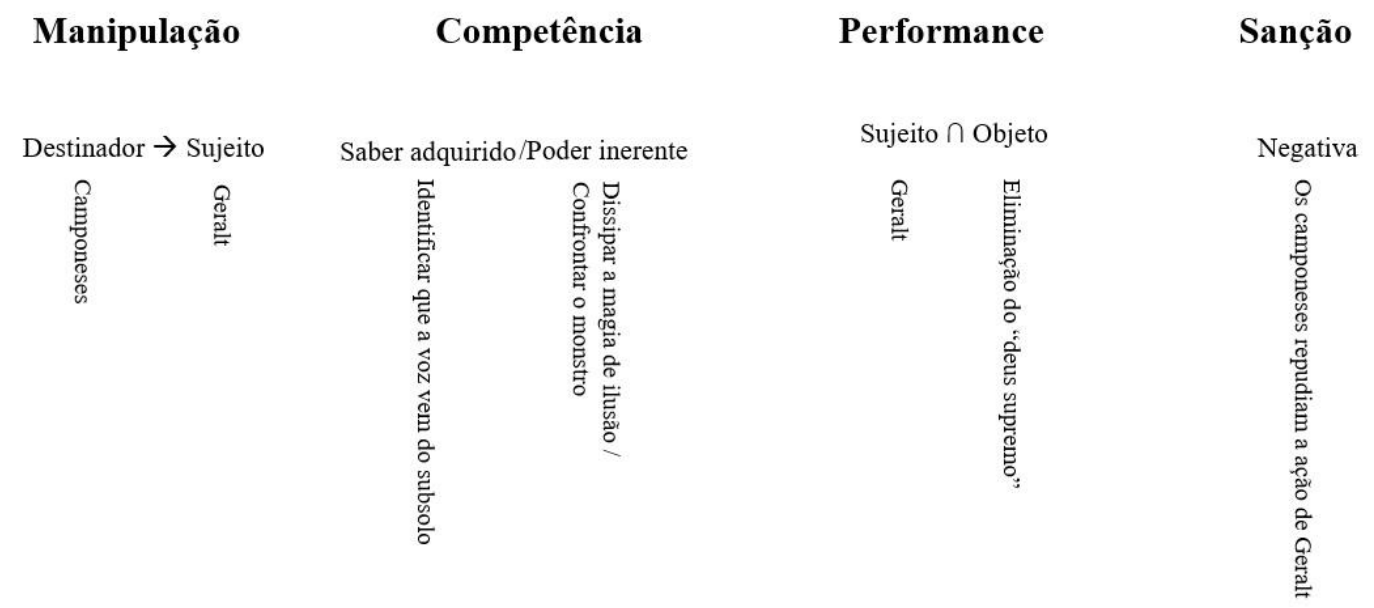

(Figura 3.59 - Programa narrativo de "Um deus ganancioso")

Podemos afirmar que "Um deus ganancioso" faz um passeio intertextual pelos episódios de ofertas a Deus na cultura judaico-cristã, mais especificamente o que separamos no início deste subcapítulo, criando uma relação pela chave da paródia.

Segundo Norma Discini:

A paródia inverte (...) o texto-base, mas tem nele sua mira enunciativa, o que significa que se mantém apegada a ele. São os valores do texto-base que a orientam, por isso ela constrói o seu discurso, para contrariar tais valores.

Na paródia, o texto-base, recontextualizado, provoca o contraste, que, por sua vez, provoca o efeito de sentido da comicidade. (DISCINI, 2004, p. 39, grifos nossos)

O efeito cômico é evidenciado nas falas de Geralt, seja quando aborda o altar com ironia, seja quando faz piada com a robusteza da criatura.

No texto-base que tomamos como exemplo, Deus quer o melhor que alguém pode oferecer a Ele como oferta, dando a entender que Caim guardou as melhores produções da sua terra para si e Lhe entregou oferendas indiferentes. $\mathrm{O}$ "deus supremo" presente em The Witcher III não só faz exigência das melhores ofertas, como as nomeia: bacon e cerveja, o que em si já causa estranhamento. 
Vale ressaltar que a cultura judaico-cristã não é a única que tem em seus textos religiosos cenas de ofertas a uma figura divina, no entanto, conseguimos identificar que é nela que a variante intertextual se baseia pela figura que se põe como deus. O que Geralt encontra nas ruínas é um silvano. Segundo a própria mitologia de The Witcher:

Os silvanos e os yakshas, são criaturas da floresta extremamente raras, cujo aspecto combina característica de cabras e homens rechonchudos. Essas criaturas costumam representar pouco perigo, pois limitam o seu contato com seres humanos a truques inofensivos (embora irritantes) e a comer as suas plantações ${ }^{48}$

O silvano charlatão não é o primeiro que o protagonista encontra em sua vida. No capítulo "Os confins do mundo", de $O$ último desejo, primeiro livro da série de Sapkowski, Geralt aceita um contrato para caçar um diabo.

- E então? - não aguentou mais o poeta. - O que aconteceu?

- Pois é... - Dhun ergueu a cabeça e coçou-se atrás da orelha. - Pois é... um diabo vagueia por aquela campina.

- O quê? - surpreendeu-se Jaskier. - O que vagueia pela campina?

- Já disse: um diabo.

- Que tipo de diabo?

- E de que tipo deveria ser? É um diabo, e basta.

- Não existem diabos!

- Não se intrometa, Jaskier - falou calmamente Geralt. - Prossiga, senhor Dhun.

- Mas eu já disse: um diabo.

- Sim, entendi. - Geralt, quando queria, era capaz de demonstrar infinita paciência. Diga-nos qual é a sua aparência, de onde ele surgiu e em que atrapalha vocês. E, se possível, ponto por ponto, uma coisa de cada vez.

- Pois é (...) sua aparência é a de um diabo, exatamente como um diabo deve ser. (SAPKOWSKI, 2016, p. 200-201).

Baseado nas informações recebidas do contratante, Geralt e seu amigo poeta Jaskier vão até um canhameiral, onde é dito o diabo habitar, e entram em conflito com ele. A criatura dispara uma quantidade incontável de bilhas, atingindo a dupla e forçando-

\footnotetext{
${ }^{48}$ Disponível em: https://thewitcher.fandom.com/pt-br/wiki/Silvanos. Acesso em 21/01/2020.
} 
a a bater em retirada. De volta ao vilarejo, o protagonista busca conselhos com uma anciã, conhecida por ser fonte de sabedoria. Então temos a descrição de que um silvano e o diabo têm a mesma aparência na mitologia de The Witcher.

A velhinha, contendo com dificuldade o tremor das mãos, virou algumas páginas. O bruxo e o poeta se inclinaram sobre a mesa. Com efeito, a água-forte mostrava a figura do atirador de bilhas: cornudo, peludo, com cauda e um sorriso malicioso nos beiços macios.

- O diabo - recitou a velhota -, também chamado de salgueiro ou silvano. Às propriedades e animais domésticos é muito perverso e incômodo. (Idem, p. 211).

Apesar de representar a figura completamente oposta a Deus no Velho Testamento, em "Um deus ganancioso" o silvano procura se assimilar a uma divindade, não para realmente comandar sobre os aldeões, mas só para roubar-lhes as comidas gordurosas, o que causa o efeito de comicidade.

Se abordarmos a variante pela modalidade veridictória, checamos que o silvano parece um deus, porque age e fala como um, no entanto, não é um deus, configurando-se uma mentira, o que coincide com a relação da paródia com o texto-base, causando o humor.

A paródia resulta de um conflito entre enunciação enunciada e enunciado enunciado, na medida em que o texto-base, implícito na enunciação, é rejeitado pelo enunciado da variante intertextual; rejeitado, entretanto, no modo do ser e não no modo do parecer da paródia. (DISCINI, 2004, p. 73).

\subsubsection{A loba em pele de Chapeuzinho}

"Chapeuzinho vermelho", de Charles Perrault, é um dos contos da tradição ocidental que se perpetuou ao longo dos tempos, recebendo inúmeras adaptações até os dias de hoje.

Na narrativa composta no século XVII, a protagonista é uma bela garotinha de um vilarejo, cuja avó a amava tanto que "mandara fazer um chapeuzinho vermelho, e este 
caía tão bem na menina, que em todos os lugares passaram a chamá-la Chapeuzinho Vermelho" (PERRAULT, 2015, p. 37).

Um dia, a mãe de Chapeuzinho assa uma torta e pede para a garota ir checar o estado de saúde da avó, que morava em outro vilarejo, depois de uma floresta. Caminhando até lá, no meio do caminho se deparou com um lobo.

Perguntou aonde ela ia; a pobre criança, que não sabia que é perigoso parar para dar ouvidos a um lobo, disse:

- Vou visitar minha avó e lhe levar uma torta com um potinho de manteiga que minha mãe está mandando.

- E ela mora longe? - perguntou o lobo.

- Ah! Mora - disse Chapeuzinho Vermelho -, para lá do moinho que se vê lá longe, lá longe, na primeira casa da aldeia. (Idem)

O lobo, astuto e malicioso, diz querer visitar a velhinha também e propõe à menina apostarem uma corrida até lá, pegando o caminho curto, enquanto Chapeuzinho segue pela estrada longa, demorando mais.

Ao ser atendido pela vovó, o lobo disfarça a voz e consegue adentrar a casa, devorando a velhinha rapidamente e tomando o seu lugar na cama. Quando a garota chega, o vilão afina a voz e a convida a entrar.

O lobo, ao vê-la entrar, disse-lhe se escondendo na cama, debaixo das cobertas:

- Põe a torta e o potinho de manteiga em cima da arca e vem se deitar comigo.

Chapeuzinho Vermelho tira a roupa e se enfia na cama, mas fica bem espantada ao ver como a vovó era em roupas íntimas. Então disse:

- Vovó, que braços compridos a senhora tem!

- É para te abraçar melhor, minha neta.

(...)

- Vovó, que dentes grandes a senhora tem!

- É para te comer.

E, dizendo isso, o lobo mau pulou em cima do Chapeuzinho Vermelho e a comeu. (Idem, p. 39). 
Para comentarmos o texto de Perrault, lançaremos mão do capítulo dois de Intertextualidade e conto maravilhoso, já que "Chapeuzinho Vermelho" foi o principal objeto de estudo da autora.

Norma Discini considera que o nível fundamental do conto tradicional lida com a oposição /identidade/ VS. /alteridade/, em que a primeira, representada pelo comportamento não completamente obediente de Chapeuzinho, é tida como disfórica.

"Chapeuzinho Vermelho", construindo suas leituras a partir da oposição fundamental alteridade vs. Identidade, começa pela afirmação da alteridade, que é manifestada na autoridade da mãe, da avó, no espaço coercitivo do lar. A menina tenta ousar, transgredir, negando a alteridade e afirmando a identidade. Não dá certo, e surge a punição: o lobo devora a menina. O texto, então, passa a negar a identidade, implicando uma afirmação da alteridade, o que subentende uma circularidade das relações. (DISCINI, 2004, p. 83).

A autora ainda expande, aplicando as oposições de /vida/ VS. /morte/ e /cultura/ VS. /natureza/, onde a natureza se alia ao campo da identidade, sendo considerada disfórica no conto.

Revelar-se-á o salto da "cultura" e da "vida" para a "natureza" e "morte". Pelo medo imposto à negação da "cultura", negar-se-á a "natureza", desejar-se-á um mero apêndice de "vida", que nada mais é do que a "não-morte". O que deve importar é estar em conjunção com a segurança, a estaticidade, a não-ruptura. É para lá que o discurso nos levará.

A reflexão, a crítica e a busca da individualidade, revestidas do traço de ousadia e (des)encaminhadas semanticamente para a disforia da dêixis negativa, acenam com a morte como punição. É de lá que o discurso quer-nos afastar, e o faz com uma cruel e eficaz "advertência", que permanece no segredo do próprio discurso. (Idem, p. 89).

Tal "advertência" nos é apresentada na moral da história, onde o narrador orienta, principalmente as "mocinhas" a não "ouvirem qualquer tipo de gente", reforçando a /alteridade/ e a /cultura/ como benéficas. 
Vemos aqui que os pouco experientes,

E acima de tudo as mocinhas,

Gentis, bem-feitas, bonitinhas,

Fazem mal em ouvir qualquer tipo de gente,

Por isso é que nunca me espanta

Que o lobo chegue a comer tantas. (...) (PERRAULT, 2015, p. 39, grifos nossos)

Quanto ao nível narrativo de "Chapeuzinho Vermelho", Norma Discini o descreve, já aplicando um olhar analítico:

"Chapeuzinho Vermelho" é a história de um sujeito ("menina"), manipulado por um sujeito ("mãe"), para que saia de casa, vá ver a avó, vá ao espaço externo.

O sujeito "menina" quer cumprir e realmente cumpre o acordo, para que se mantenham os valores que já possui: o clã, o abrigo, o carinho - o "outro". Era bela e muito querida, o que subentende sem "defeitos" morais ou físicos. Reconhecida como "boa" (pressuposto) e "bela", é recompensada com o "chapeuzinho vermelho", que a torna ainda mais bela, isto é, ainda mais em conjunção com o "o outro" ("a cultura").

Surge o lobo, com outros valores: os da "natureza", que se opõem à "cultura", e que supõem a ruptura, a "liberdade" de ser ela própria - sem mãe, nem avó, nem dever (ser ou fazer). Esses valores tentam o sujeito "menina", fazendo com que ela vá pelo caminho mais longo e permaneça no bosque, esquecida do primeiro compromisso.

A permanência no bosque representa o rompimento do primeiro contrato. A menina transforma-se num sujeito verdadeiramente rebelde: parece e é. Assume o valor da "liberdade".

Quando chega à casa da avó, começa o percurso inverso: entra em disjunção com a "liberdade", negando-a, renunciando a ela, por isso ouve a voz do lobo e sente medo, por isso vê o lobo/avó e sente espanto. Arrepende-se, mas é tarde. O lobo a devora.

A menina é sancionada pela ruptura do contrato fiduciário com a mãe, ruptura essa que confirma a mentira da conjunção com a "submissão" no PN prévio. (DISCINI, 2004, p. 93-94).

O tema "épico" está presente, assim como em boa parte dos contos de fadas. Aqui, não há figuras como castelos ou príncipes, no entanto, temos "aldeia", "bosque", "lenhadores" e o lobo, um animal antropomorfizado, figura recorrente em fábulas. Curiosamente, a figura lupina também engloba o tema da violência, que pode ser interpretada de duas formas, já que é descrito que o vilão devora Chapeuzinho, mas também, que a garota se deita na cama com ele antes de ser atacada, o que abre a 
possibilidade de uma interpretação relacionando a figura do lobo ao abuso sexual, reforçado por Perrault na moral da história também.

(...) Por isso é que nunca me espanta

Que o lobo chegue a comer tantas.

Eu digo "o" lobo, porque há raças

Que atuam de uma outra maneira;

Que têm atitude fatigueira,

Sem barulho, raiva, ameaças,

Que mansos, meigos e com graça,

Perseguem as mocinhas novas

Dentro de casa até, e mesmo nas alcovas;

Que dó! Quem saberá que esses lobos melosos,

Entre todos que há são os mais perigosos. (PERRAULT, 2015, p. 39-40).

Já em The Witcher III: Wild Hunt, a missão "Chapeuzinho" alude intertextualmente ao texto de Perrault de forma bastante curiosa.

Cavalgando ao norte da cidade de Oxenfurt, Geralt adentra uma aldeia e é chamado por um grupo de homens que clamam pela sua ajuda. Segundo os aldeões, o bando da Chapeuzinho está prestes a invadir o vilarejo, pois juraram vingança a um deles. 


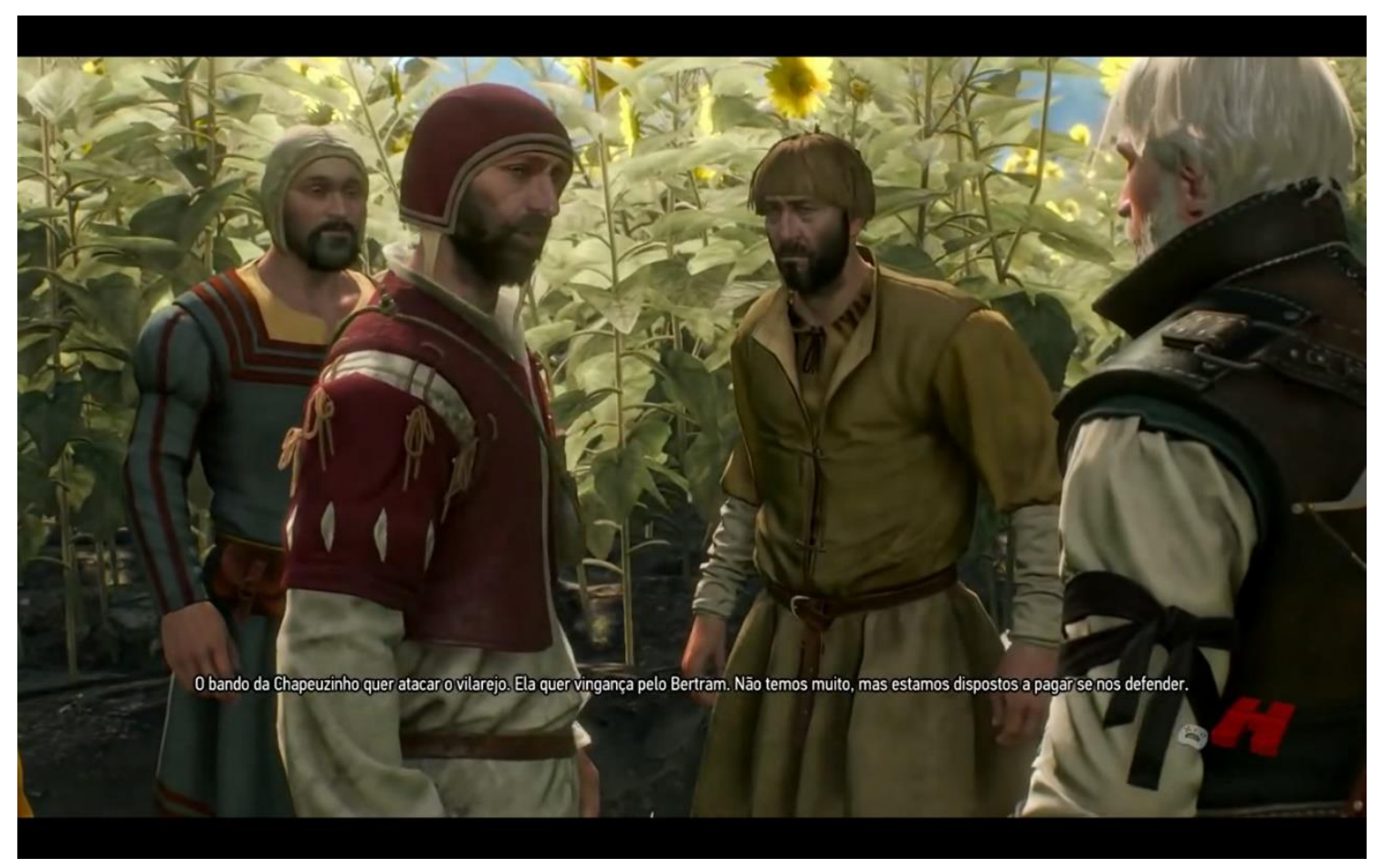

(Figura 3.60 - O aldeão explica a situação: "O bando da Chapeuzinho quer atacar o vilarejo. Ela quer vingança pelo Bertram. Não temos muito, mas estamos dispostos a pagar se nos defender.")

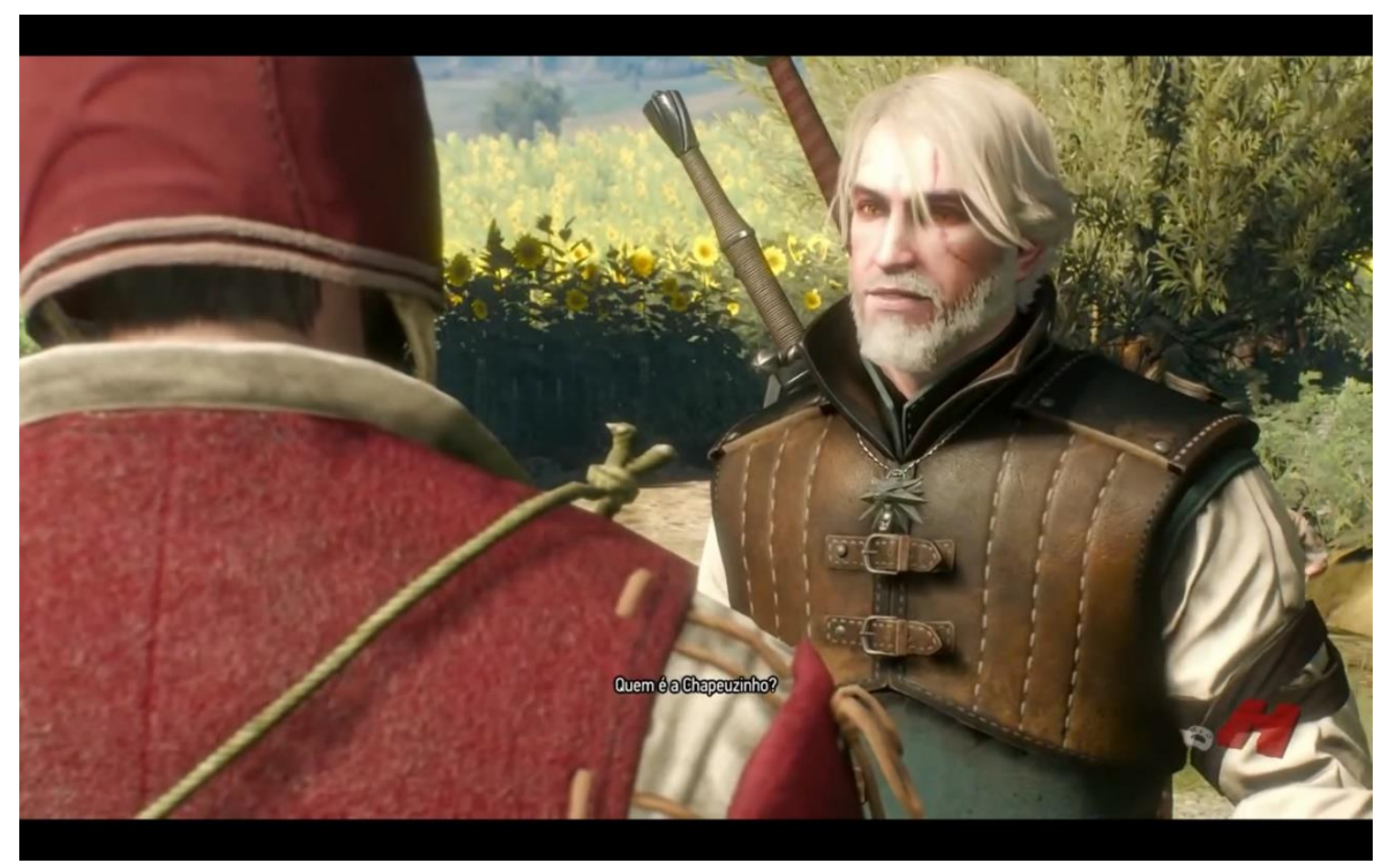

(Figura 3.61 - Geralt pergunta sobre a Chapeuzinho.) 


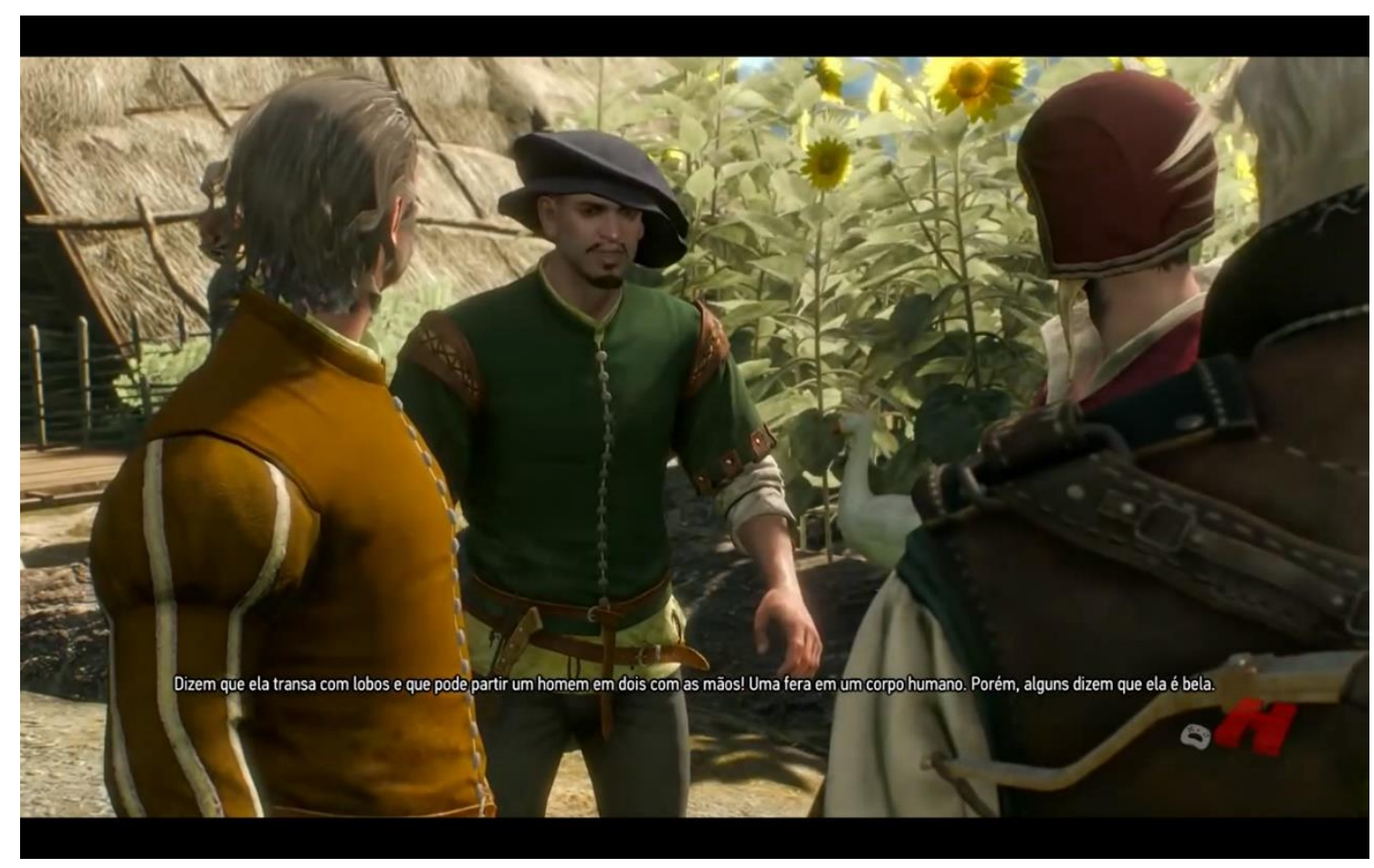

(Figura 3.62 - "Dizem que ela transa com lobos e que pode partir um homem em dois com as mãos! Uma fera em um corpo humano. Porém, alguns dizem que ela é bela.")

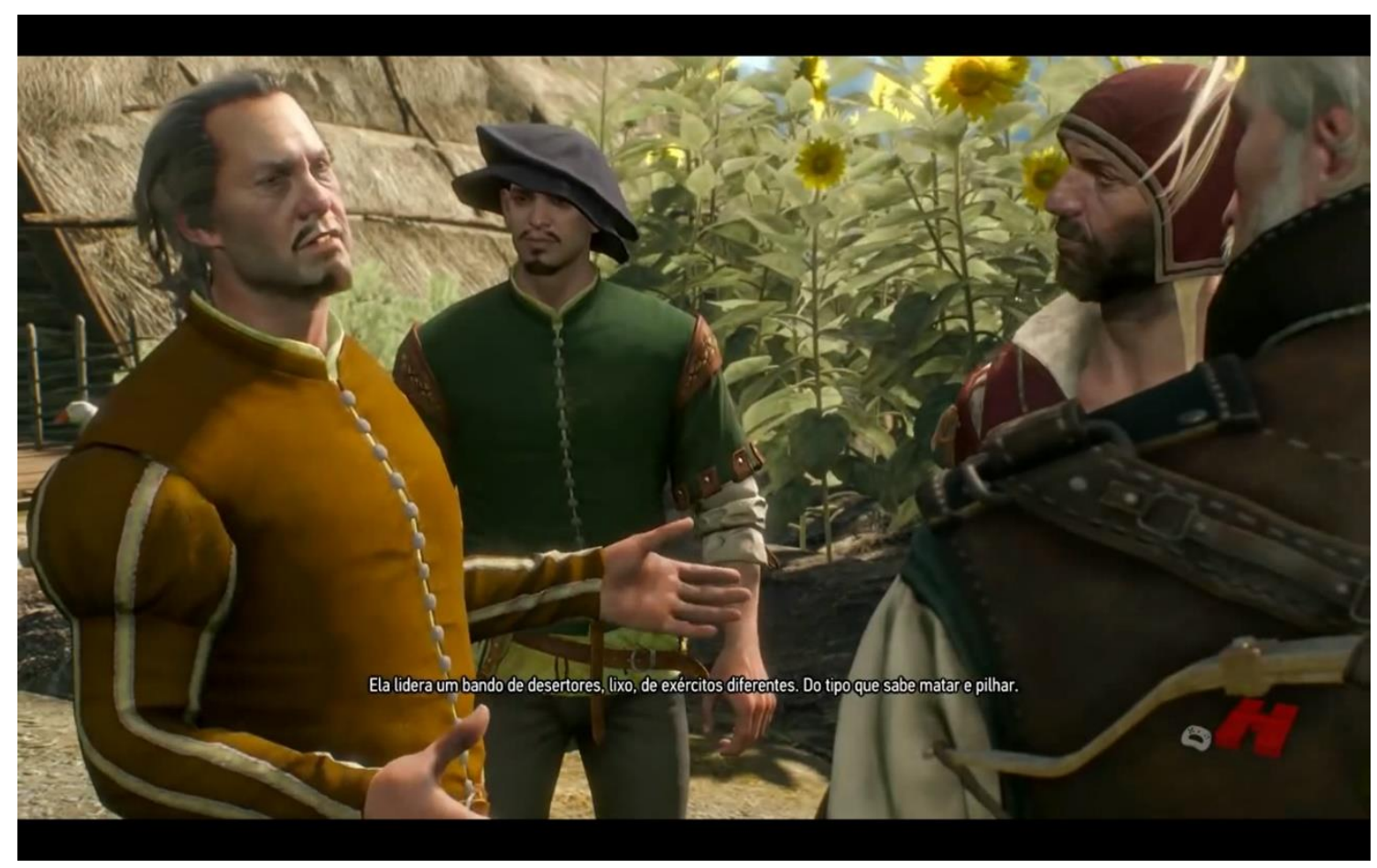

(Figura 3.63 - "Ela lidera um bando de desertores, lixo, de exércitos diferentes. Do tipo que sabe matar e pilhar.")

Disposto a ajudar os aldeões, Geralt busca descobrir qual é a razão para Chapeuzinho desejar vingança contra Bertram. Este, em meio aos seus companheiros, relata que havia recorrido aos caçadores de bruxas para perseguirem os bandidos, já que 
o vilarejo não conseguia ajuda de mais ninguém. A descoberta de que Bertram havia entregado a posição do bando aos caçadores seria a razão pela qual Chapeuzinho buscava matá-lo.

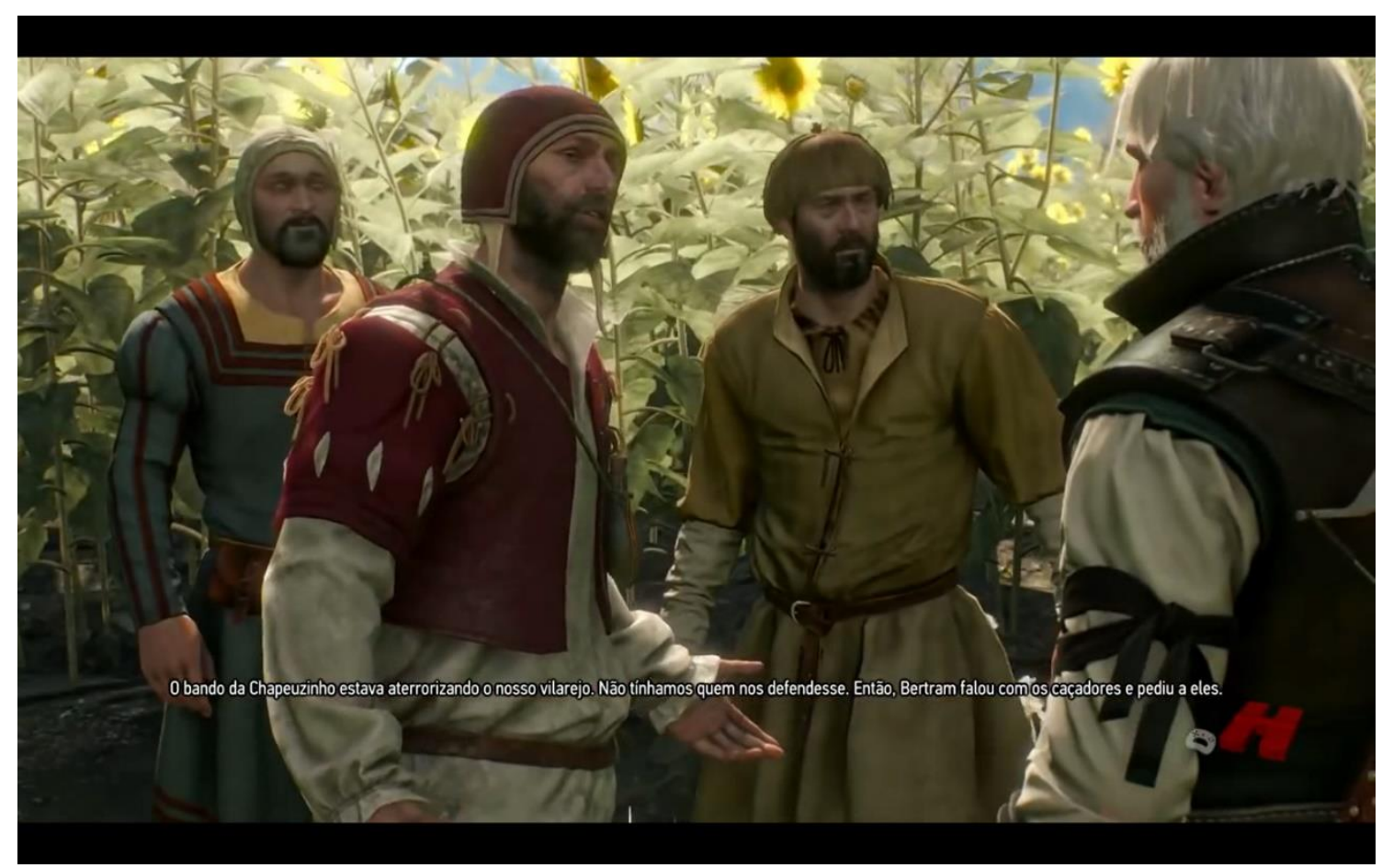

(Figura 3.64 - "O bando da Chapeuzinho estava aterrorizando o nosso vilarejo. Não tínhamos quem nos defendesse. Então, Bertram falou com os caçadores e pediu a eles.") 


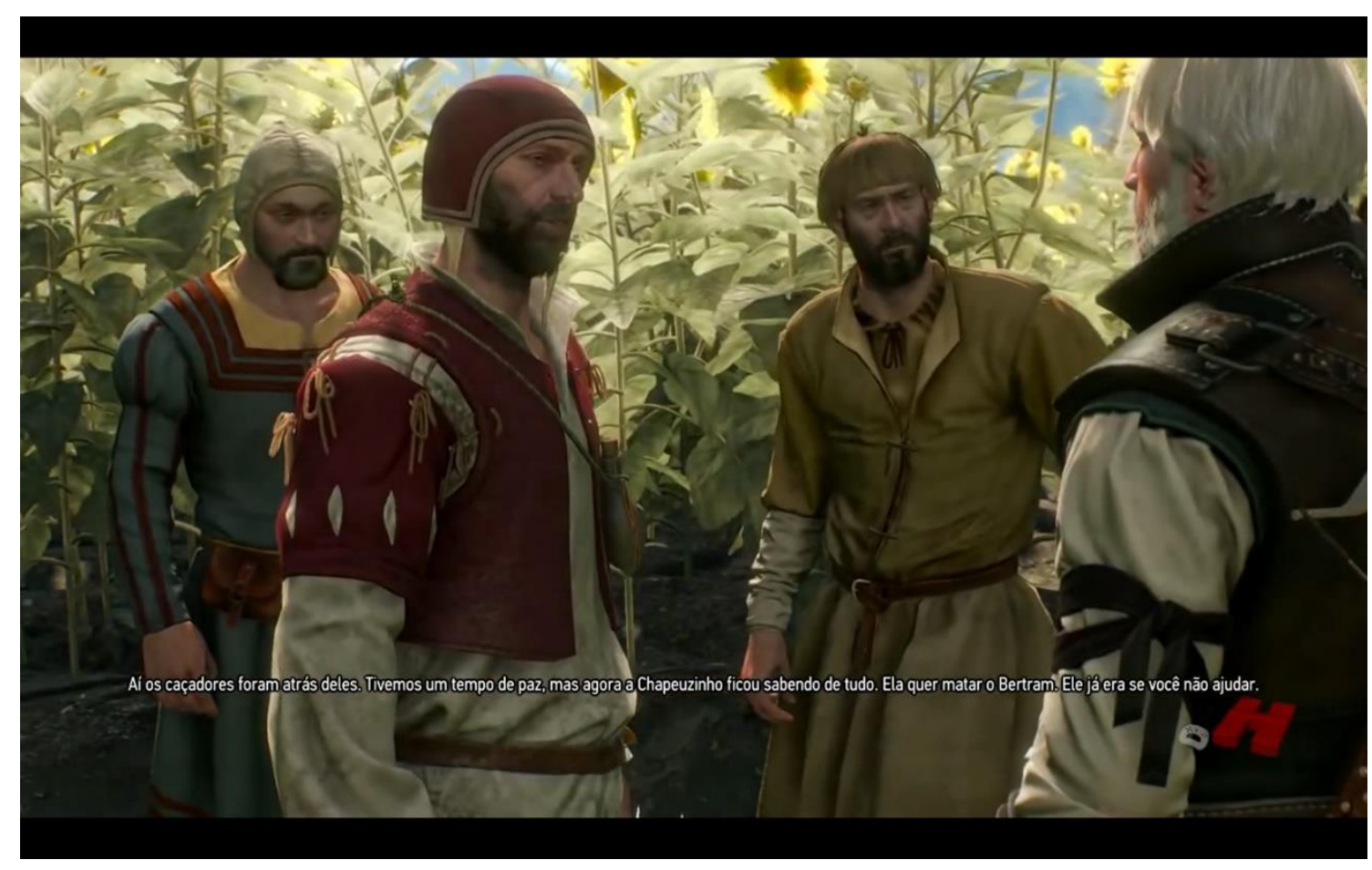

(Figura 3.65 - "Aí os caçadores foram atrás deles. Tivemos um tempo de paz, mas agora a Chapeuzinho ficou sabendo de tudo. Ela quer matar o Bertram. Ele já era se você não ajudar.")

Geralt decide auxiliar os aldeões, ficando no vilarejo até anoitecer. Próximo da meia-noite, o grupo de bandidos invade o local e começa a procurar por Bertram. Decidido a intervir, o protagonista vai até a líder deles, vestida com um chapeuzinho vermelho e pele de lobo sobre os ombros. 


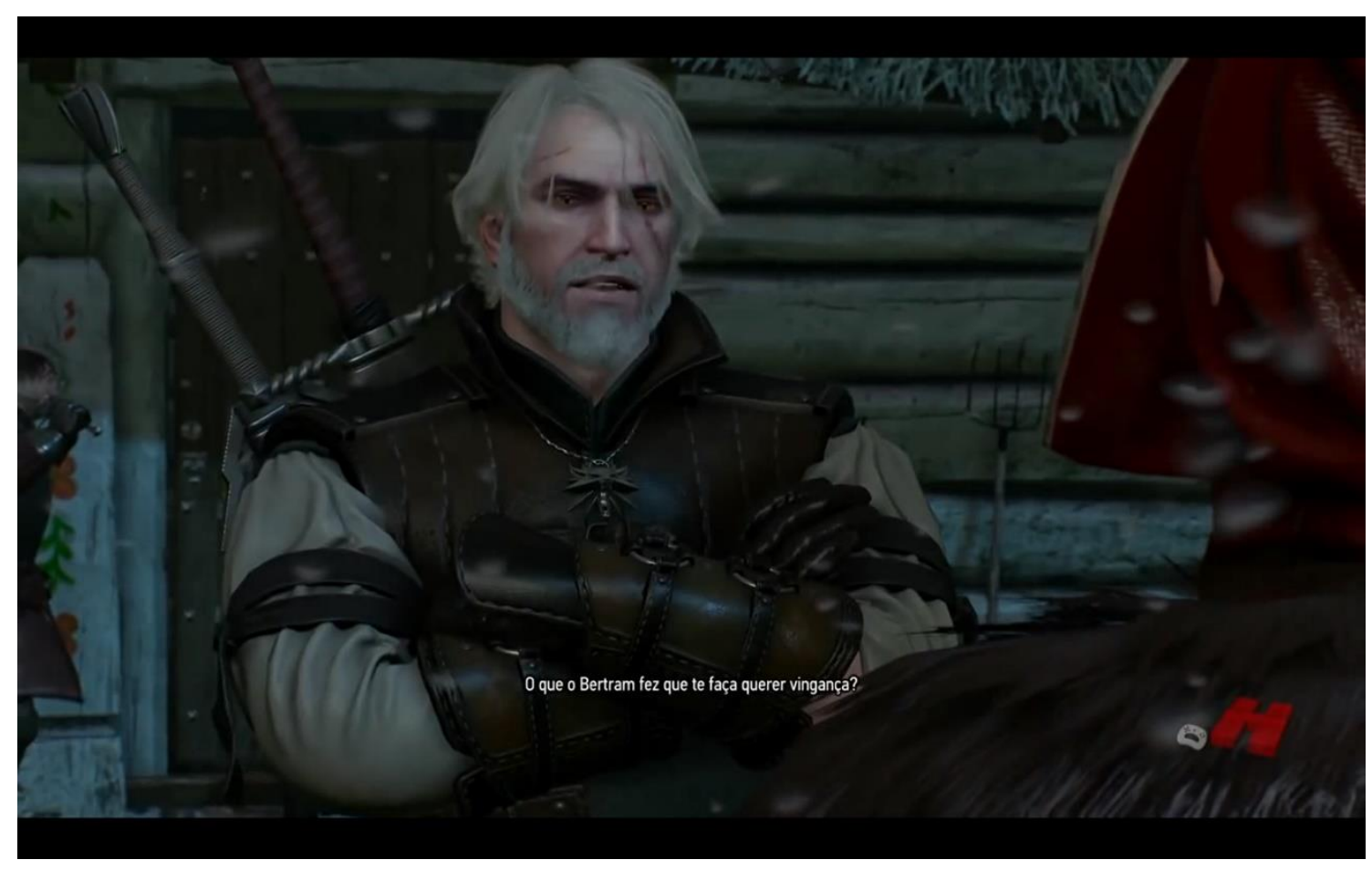

(Figura 3.66 - Geralt indaga Chapeuzinho: "O que o Bertram fez que te faça querer vingança?")

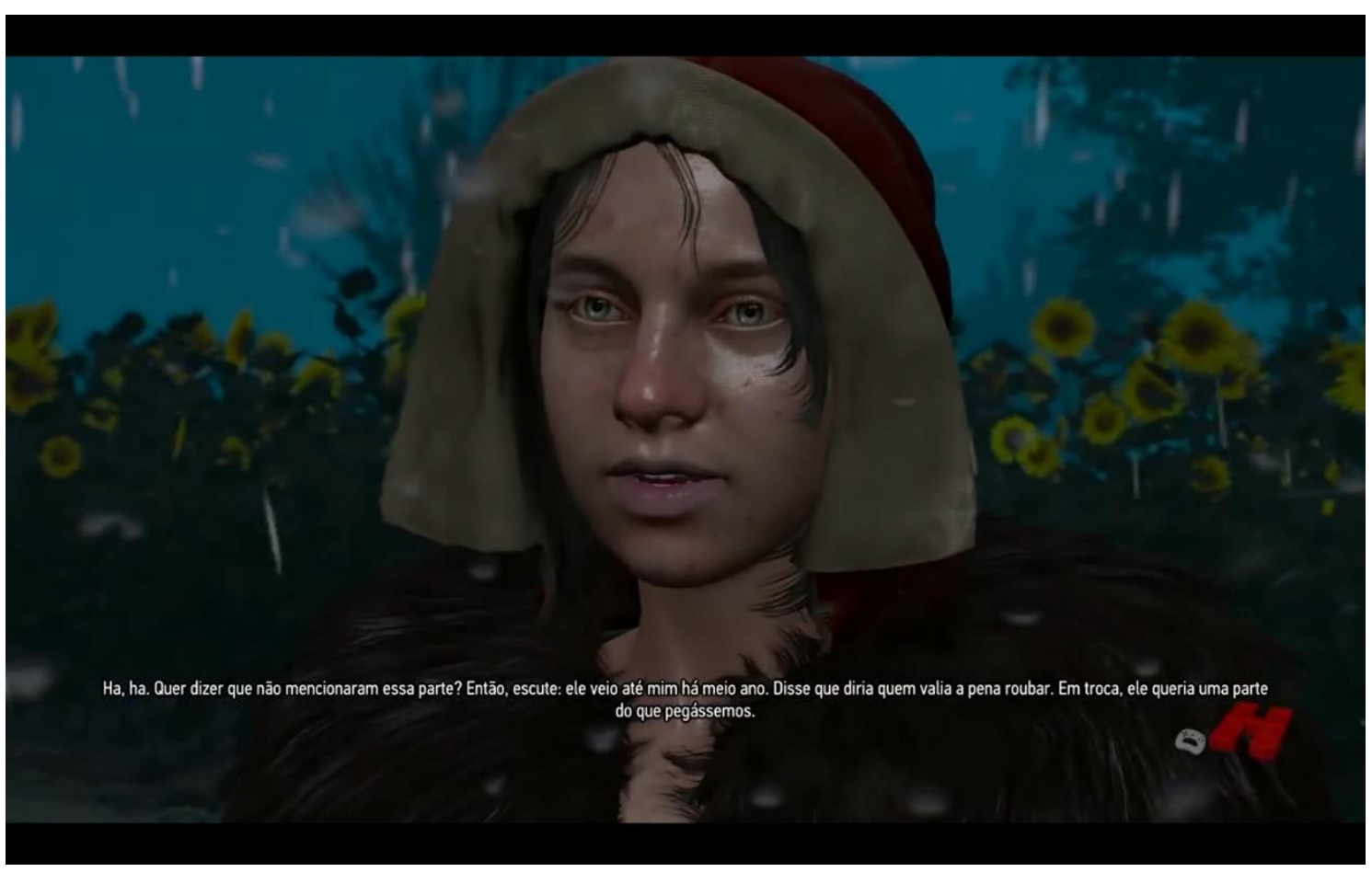

(Figura 3.67 - "Quer dizer que não mencionaram essa parte? Então, escute: ele veio até mim há meio ano. Disse que diria quem valia a pena roubar. Em troca, ele queria parte do que pegássemos.") 


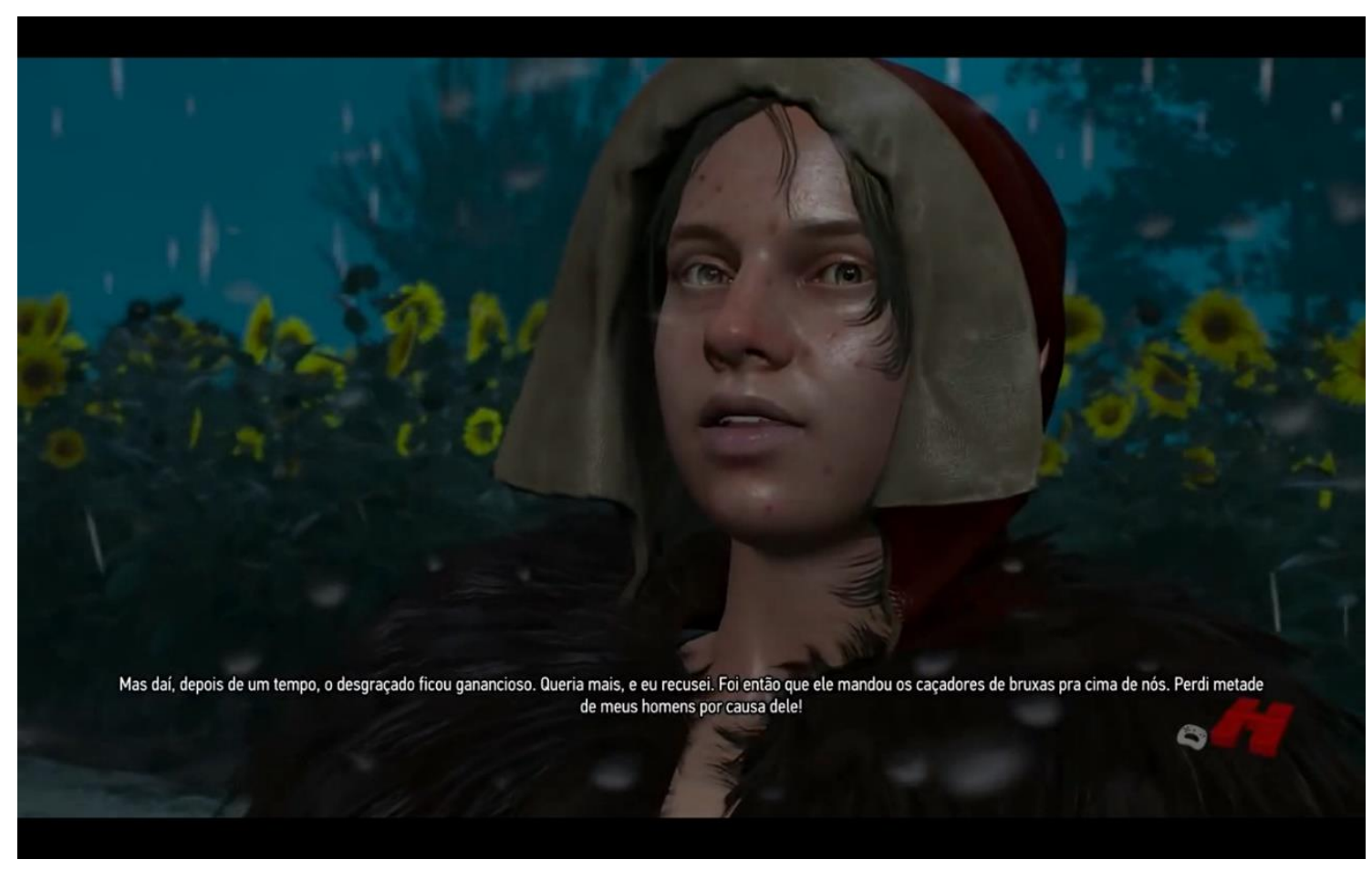

(Figura 3.68 - "Mas daí, depois de um tempo, o desgraçado ficou ganancioso. Queria mais, e eu recusei. Foi então que ele mandou os caçadores de bruxas para cima de nós. Perdi metade de meus homens por causa dele!")

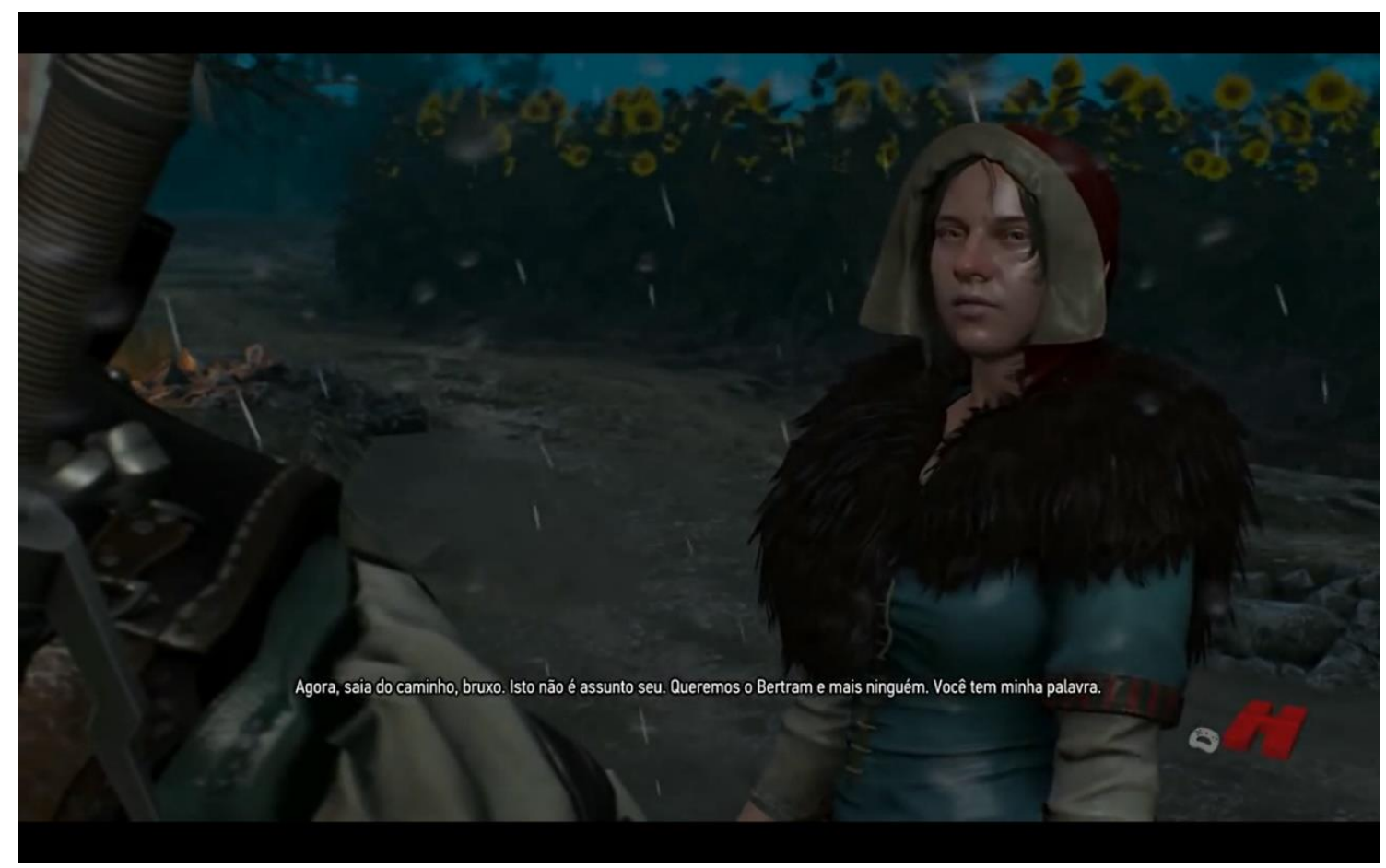

(Figura 3.69 - "Agora, saia do meu caminho, bruxo. Isto não é assunto seu. Queremos o Bertram e mais ninguém. Você tem a minha palavra" diz Chapeuzinho, determinada.) 


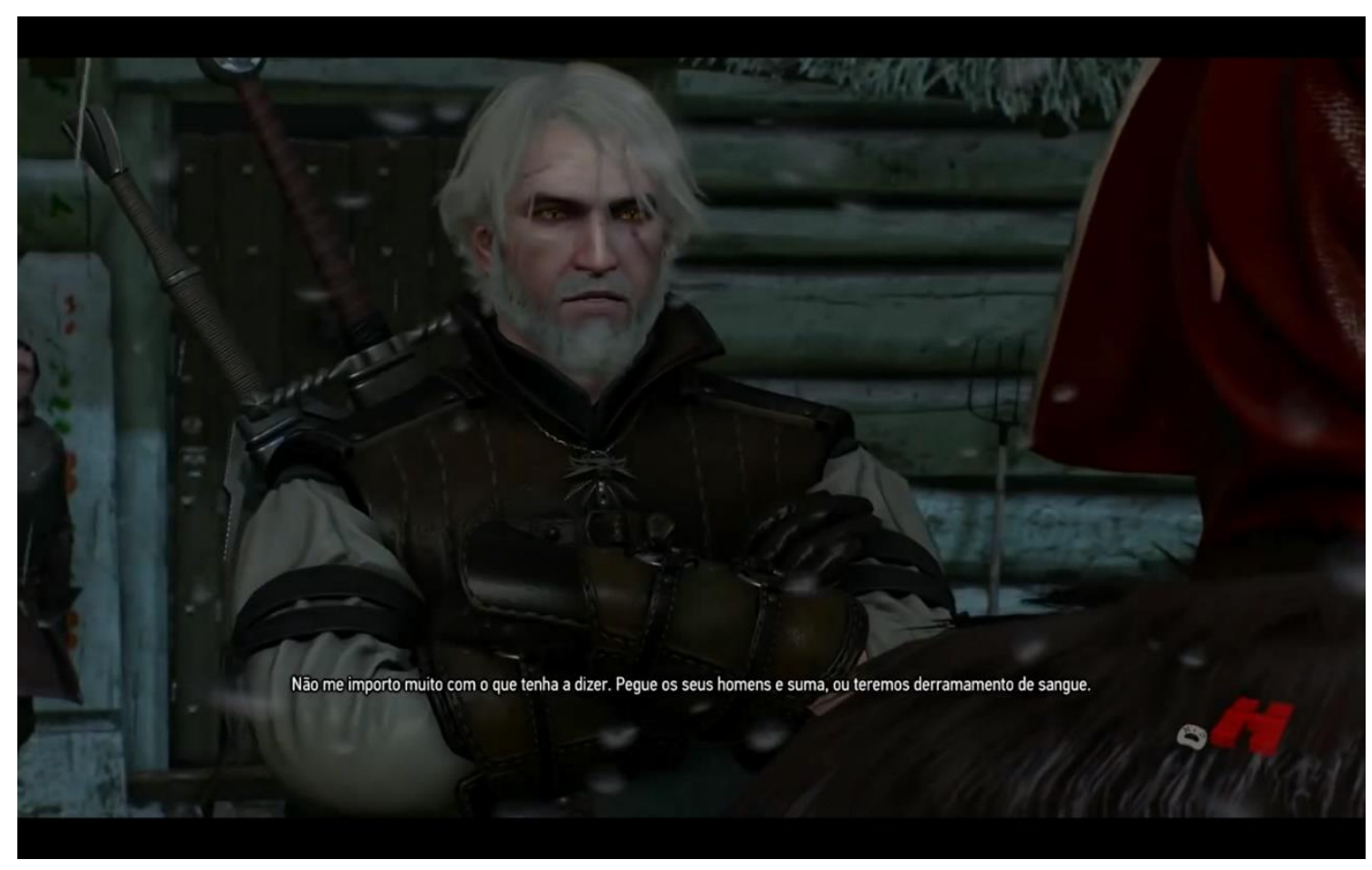

(Figura 3.70 - "Não me importo muito com o que tenha a dizer. Pegue os seus homens e suma, ou teremos derramamento de sangue." frisa Geralt.)

Chapeuzinho se ira com a postura do protagonista e anuncia o combate. De repente, para a surpresa de Geralt, a moça se revela ser, na verdade, um lobisomem.

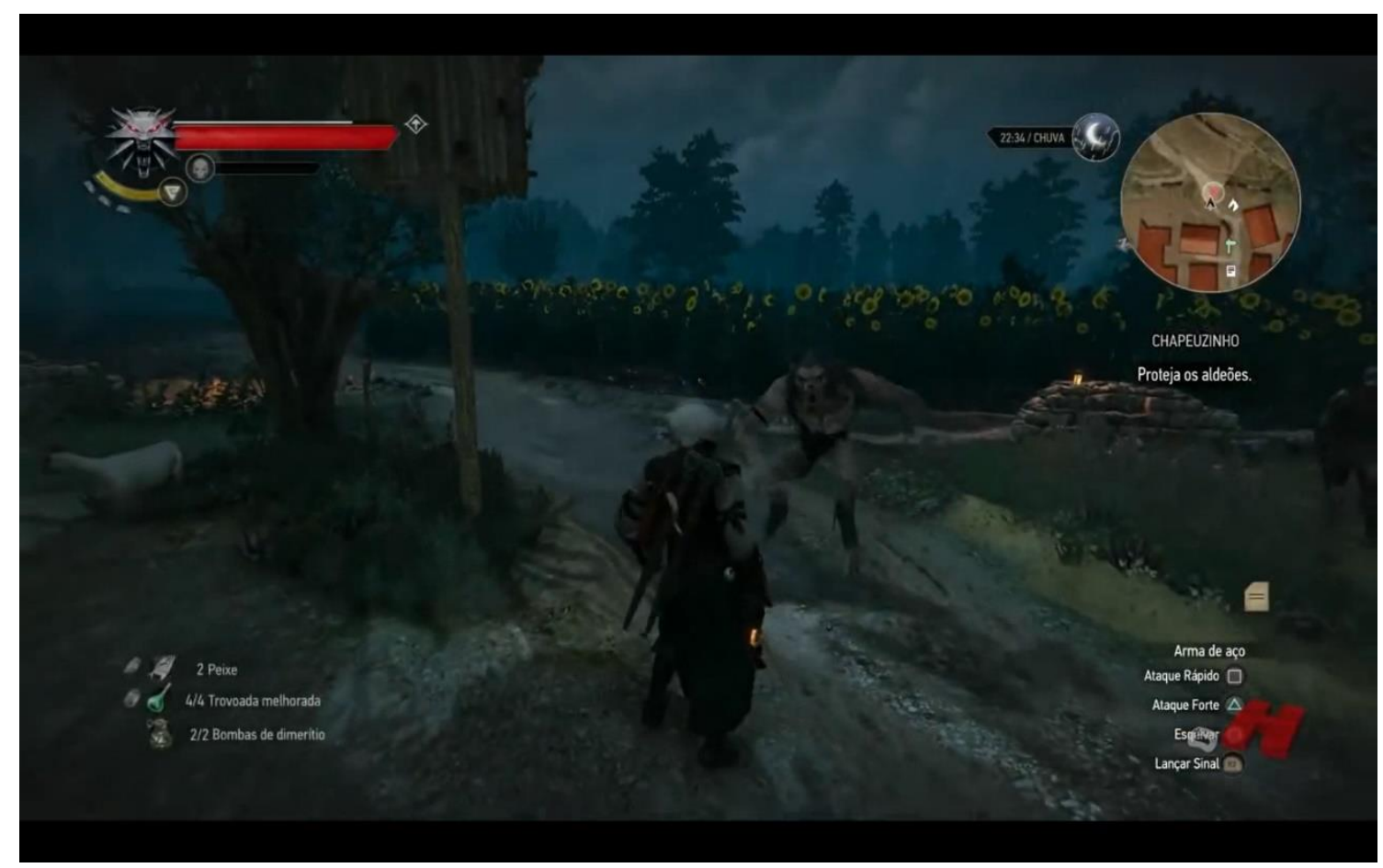

(Figura 3.71 - Chapeuzinho se transforma em um lobisomem (centro).) 
Após vencer o combate, o protagonista indaga aos aldeões o fato de não terem mencionado o perigo a ele, no entanto, o magistrado da aldeia relata que nenhum deles tinha certeza sobre o boato da garota ser um monstro. Agradecido, o homem paga a Geralt e o despede.

Temos aqui uma relação intertextual com o conto de Perrault feita de modo sutil. Apesar de Geralt ser o sujeito do programa narrativo da missão "Chapeuzinho", lutando contra um monstro que pode matá-lo e a qualquer camponês da aldeia, direcionaremos o foco à personagem Chapeuzinho.

Como visto, apoiados em Discini, "Chapeuzinho Vermelho" lida com a oposição /identidade/ VS. /alteridade/, onde a /cultura/ e a /vida/ são expansões da /alteridade/ e a /natureza/ e a /morte/ são da /identidade/. No ambiente coercitivo do lar, são impostos à menina os valores da /alteridade/, porém, ao sair de casa e resolver deixar por um tempo a sua tarefa prevista de lado, insere-se nos valores da /identidade/, transgressora.

O ponto curioso da narrativa em análise do jogo eletrônico é que o texto faz menção direta ao conto de Perrault no momento em que um dos camponeses diz haver um boato de que "Chapeuzinho transa com lobos" (ver Figura 3.62), aludindo ao final trágico da história original, demonstrando que The Witcher III está dialogando realmente com o texto-base e não com outras variantes, como poderia ser com a versão dos Grimm.

Se tomarmos a vilã Chapeuzinho como referencial, a oposição /identidade/ VS. /alteridade/ se mantém, entretanto, a personagem é só /identidade/. Chapeuzinho de The Witcher III é transgressora em todos os momentos, de forma que se mostra uma figura poderosa até para corromper Bertram a se inserir na vida de crimes. Além do mais, o que é o grande diferencial do jogo, Chapeuzinho é a figura selvagem, é a criatura caçada (ver Figura 3.64), e, mais importante, é a junção da figura do lobo implacável à menina bela, o que subverte o texto-base de Perrault.

"Chapeuzinho" do jogo eletrônico The Witcher III: Wild Hunt não parece um conto tradicional e nem é, o que configura a variante como uma polêmica, segundo Norma Discini: 
A polêmica resulta de um conflito entre a enunciação enunciada e o enunciado enunciado, na medida em que o texto-base, implícito na enunciação, é rejeitado pelo enunciado da variante intertextual; rejeitado no modo de ser e no modo do parecer da polêmica. Esse conflito resolve-se na negação do texto-base em todos os níveis; negação que culmina, ou origina-se, no nível discursivo, em que se tematizam a crítica, a denúncia, o protesto, em que se fragilizam as figuras intertextuais, em que acontece, enfim, uma contraditoriedade de isotopias, que gera ironia, sem humor. (DISCINI, 2004, p. 72-73).

Para conclusão deste capítulo, podemos afirmar que, dentro da proposta desta pesquisa, foi possível compreender em The Witcher III: Wild Hunt o uso de intertextualidade manifesta como um recurso de enriquecimento da narrativa presente no jogo eletrônico. 


\section{Considerações finais}

Mesmo tendo trabalhado com uma proposta demonstrativa em relação à manifestação da intertextualidade como fato enriquecedor da narrativa de um jogo eletrônico específico, deixamos algumas questões que surgiram ao longo do trabalho em aberto, afinal, a abordagem que tivemos dos tópicos presentes neste texto de pesquisa acadêmica não exauriram a discussão sobre os assuntos abordados, mas, pelo contrário, podem acender a chama de novas pesquisas voltadas às problemáticas encontradas.

Iniciamos buscando, na Introdução, justificar a escolha do objeto específico e o porquê de lançarmos mão da semiótica francesa como principal ferramenta para embasarmos as análises textuais. Para pesquisar a intertextualidade em episódios narrativos de um jogo eletrônico lançado em 2015 (última geração de videogames até o momento da conclusão desta pesquisa) foi necessário dar início a uma jornada de exame do terreno em torno do objeto de estudos para depois contemplá-lo da premissa que havia nos instigado. The Witcher III: Wild Hunt é um RPG eletrônico inspirado em uma série de livros do escritor polonês Adzrej Sapkowski, de modo que foi preciso inicialmente encarar as raízes do RPG, as adaptações de um jogo de lápis e papel para o meio eletrônico, a contextualização da obra de Sapkowski e um aprofundamento do personagem protagonista que seria o principal atuante dos episódios do jogo que pretendíamos analisar. Vale ressaltar que em todo momento o percurso da pesquisa foi fundamentado principalmente pelo olhar da semiótica (apesar de encarar o jogo per se, e termos experiências como jogadores, não somos especialistas da ludologia).

No primeiro capítulo abordamos as origens e o conceito do "role playing game", mais precisamente, do pioneiro do gênero, Dungeons \& Dragons. Ancorados na semiótica e caminhando pela ludologia, vimos no RPG um tipo complexo de texto que se instaura no próprio momento da enunciação, de modo que esta é basilar para que o jogo ocorra e o seu universo imaginativo se crie. Exploramos a evolução do RPG e sua adaptação ao meio eletrônico, abordando uma partida de bloggers, disponível na internet, pela lente da semiótica francesa. Algumas questões que ficam em aberto e podem ser posteriormente trabalhadas são: 1) Abarcar o ato do jogo de role playing em si e analisar, 
de maneira aprofundada, como as estratégias enunciativas do RPG se diferem de outros textos. 2) Compreender em pesquisa os processos de adaptação intersemiótica de um jogo baseado em interpretação ao vivo para um videogame que disponibiliza ao jogador falas predispostas no sistema de códigos do próprio software que permitem a ele dar voz a seu personagem e, por conseguinte, progredir a narrativa do jogo.

No Capítulo 2 justificamos a escolha de The Witcher III: Wild Hunt como principal objeto de estudo desta Dissertação, demonstrando sua relevância no universo dos videogames. Também nos debruçamos sobre a origem do jogo, baseado em uma série de livros que apresenta ao leitor um protagonista dito sem sentimentos, de modo que, agora apoiados em Semiótica das paixões, analisamos as questões passionais envolvendo o sujeito. Trabalhar com a ideia de "sem sentimentos" nos levou a associar à "apassionalidade", o que, posteriormente, vimos que, pelo olhar da semiótica, é impossível, já que, pelo que fundamenta a semiótica tensiva, é o eixo sensível que rege os sujeitos. Apesar de termos lançado mão de um pronunciamento de Lakoff, reforçamos que não somos estudiosos da área da linguística cognitiva, mas que embasamos nossas análises deste capítulo principalmente em Greimas e Fontanille (1993) e Claude Zilberberg (2011). Observando, com o suporte de Marsciani (1984), que o sujeito Geralt é predominantemente movido pela paixão da indiferença, buscamos compreender como a questão do sujeito "sem sentimentos" era abordada no jogo eletrônico que havíamos escolhido como objeto de estudo desta pesquisa, percebendo que o simulacro "sem sentimentos" no sentido de "apassional" não se sustenta, como demonstrado em breve análise da cólera no episódio da vingança de Geralt contra o bandido Willy Cipriano.

Feito todo um percurso de contextualização, chegamos finalmente à análise da intertextualidade, demonstrando como esta está intrinsecamente presente nas mídias e nos aprofundando em três episódios do jogo The Witcher III: Wild Hunt, considerados variantes intertextuais de narrativas de alto valor cultural no Ocidente. Também reforçamos que as problemáticas presentes nos segundo e terceiro capítulos podem suscitar questões a serem analisadas, tais como: 1) Manifestações passionais em personagens de jogos eletrônicos. 2) Como o sensível rege o jogador a progredir a narrativa do jogo eletrônico? 3) Com a presença de recursos textuais que complexificam suas narrativas, como diferenciar um jogo eletrônico artístico de um simples subproduto da cultura de massas? 
Nosso principal objetivo desta Dissertação foi demonstrar, por meio de análise semiótica, como a intertextualidade enriquece a narrativa do RPG eletrônico de ação The Witcher III: Wild Hunt, presente no Capítulo 3. Desta forma, exibido ao leitor o que buscávamos analisar por meio desta pesquisa, fica às mãos deste mais uma manifestação acadêmica que o convida a perspectivar o jogo eletrônico como objeto cada vez mais pertinente para o olhar da semiótica e de outras teorias do texto. Encerra-se esta Dissertação no mesmo eixo que se iniciou, através de breve narração simulando a conclusão de uma partida de RPG de lápis e papel:

"Você termina de ler o texto e pousa o livro sobre a face de madeira da escrivaninha. O vento já não sopra mais e um silêncio expressivo envolve o ambiente, como se a poltrona, o abajur, a samambaia, as cortinas e os livros esperassem a sanção de sua boca. A tal Dissertação foi-te relevante até que ponto? Você sorri, preparando-se para dar a resposta para si...” 


\section{Referências}

ANGELO, J. R. C. Análise semiótica de videogames: uma aposta na Interdisciplinaridade. Dissertação (Mestrado) - Universidade Federal Fluminense, 2015. Disponível em:

https://app.uff.br/riuff/bitstream/1/3002/1/Disserta\%C3\%A7\%C3\%A3o\%20de\%20Mest rado\%20Romero.pdf. Último acesso em 01/11/2019.

BARROS, D. L. P. de. Teoria semiótica do texto. 4ªed. São Paulo: Ática, 2005.

BAKHTIN, M. Questões de literatura e estética: a teoria do romance. Trad. Aurora Fornoni Bernardini. $7^{\mathrm{a}}$ ed. São Paulo: Hucitec, 2014.

DISCINI, N. Intertextualidade e conto maravilhoso. $2^{\mathrm{a}}$ ed. São Paulo: Associação Editorial Humanitas, 2004.

ERNICA, R. R. Ensaio semiótico sobre a narratividade nos jogos digitais. Dissertação (Mestrado) - Faculdade de Filosofia, Letras e Ciências Humanas, Universidade de São Paulo, 2014. Disponível em: https://teses.usp.br/teses/disponiveis/8/8147/tde-22052015095739/pt-br.php. Último acesso em 27/02/2019.

EWALT, D. M. Dados e homens: a história de Dungeons \& Dragons e de seus jogadores. Trad. Rodrigo Salem. 1 ${ }^{\text {a }}$ ed. Rio de Janeiro: Record, 2016.

FIORIN, J. L. As astúcias da enunciação: as categorias de pessoa, espaço e tempo. $3^{\mathrm{a}}$ ed. São Paulo: Contexto, 2016.

FIORIN, J. L. "Interdiscursividade e intertextualidade". In. BRAIT, B. (org.). Bakhtin: outros conceitos-chave. $2^{\mathrm{a}}$ ed. São Paulo: Contexto, 2016. p. 161-193.

FIORIN, J. L. Paixões, afetos, emoções e sentimentos. CASA: Cadernos de Semiótica Aplicada. São Paulo: UNESP, vol. 5, n. 2, dezembro de 2007.

GREIMAS, A. J. Sobre o sentido II: ensaios semióticos. Trad. Dilson Ferreira da Cruz. $1^{\mathrm{a}}$ ed. São Paulo: Nankin: Edusp, 2014.

GREIMAS, A. J.; COURTÉS, J. Dicionário de semiótica. Trad. Alceu Dias Lima, Diana Luz Pessoa de Barros, Eduardo Peñuela Cañizal, Edward Lopes, Ignacio Assis da Silva, Maria José Castagnetti Sombra, Tieko Yamaguchi Miyazaki. $2^{\mathrm{a}}$ ed. São Paulo: Contexto, 2016.

GREIMAS, A. J.; FONTANILLE, J. Semiótica das paixões. Dos estados de coisas aos estados de alma. Trad. Maria José Rodrigues Coracini. São Paulo: Ática, 1993.

HUIZINGA, J. Homo Ludens: o jogo como elemento da cultura. Trad. João Paulo Monteiro. $8^{\text {a }}$ ed. São Paulo: Perspectiva, 2014. 
JUUL, J. "The Game, the Player, the World: Looking for a Heart of Gameness". In. Level Up: Digital Games Research Conference Proceedings, editado por Marinka Copier e Joost Raessens, 30-45. Utrecht: Utrecht University, 2003. Disponível em: http://www.jesperjuul.net/text/gameplayerworld/. Último acesso às 14:15 do dia 09/10/2018.

LIMA, E. S. de. A semiótica das paixões e a análise da dimensão passional dos enunciados. Revista de Estudos da Linguagem, Belo Horizonte, v.25, n. 2, p. 841-871, 2017.

LUZ, A. R. da. Vídeo games: história, linguagem e expressão gráfica. São Paulo, SP: Blucher, 2010.

MARSCIANI, F. Les parcours passionels de l'indifférence. Actes semiotiques, v. 53, 1984, p. 3-30.

PERRAUlT, C. Contos de Mamãe Gansa. Trad. Ivone C. Benedetti. Porto Alegre: L\&PM, 2015.

RANHEL, J. "O conceito de jogo e os jogos computacionais". In. SANTAELLA, Lucia; FEITOZA, Mirna (orgs.) Mapa do jogo. São Paulo: Cengage Learning, 2009: 3-22.

SAPKOWSKI, A. O útlimo desejo. Trad. Tomasz Barcinski. $2^{\text {a }}$ ed. São Paulo: Editora WMF Martins Fontes, 2015.

SAPKOWSKI, A. A espada do destino. Trad. Tomasz Barcinski. $2^{\mathrm{a}}$ ed. São Paulo: Editora WMF Martins Fontes, 2015.

SHAKESPEARE, W. Romeu e Julieta. Trad. José Francisco Botelho; Introdução de Adrian Poole. $1^{a}$ ed. São Paulo: Penguin Classics Companhia das Letras, 2016.

SHELlEY, M. Frankenstein, ou O moderno Prometeu. Trad. Doris Goettems. Edição bilíngue. São Paulo: Editora Landmark, 2016.

SOUZA JÚNIOR, P. C. de. Entre jogador e leitor: análise semiótica da adaptação de Assassin's Creed para romance. Dissertação (Mestrado) - Universidade Federal Fluminense, 2015. Disponível em:

https://app.uff.br/riuff/bitstream/1/2942/1/Disserta\%C3\%A7\%C3\%A3o\%20de\%20mest rado $\% 20-\% 20$ Paulo $\% 20 \% 20$ Cesar\%20de\%20Souza $\% 20 J \% \mathrm{C} 3 \%$ BAnior.pdf. Último acesso em 01/11/2019.

VEUGEN, C. Here be dragons: advent and prehistory of the adventure game. 2004. Disponível em: http://dare.ubvu.vu.nl/bitstream/handle/1871/11014/HereBeDragonsbw.pdf;jsessionid= 328C73A0A6488A5DB87481C215BE4EEF?sequence=2. Último acesso às 15:11 do dia $15 / 06 / 2018$.

XAVIER, G. A condição eletrolúdica: Cultura visual nos jogos eletrônicos.

Teresópolis, RJ: Novas Ideias, 2010.

ZILBERBERG, C. Elementos de Semiótica Tensiva. Trad. Ivã Carlos Lopes, Luiz Tatit, Waldir Beividas. São Paulo: Ateliê Editorial, 2011. 


\begin{abstract}
Anexos
Anexo A: Vídeos consultados para embasamento teórico e obtenção de imagens, através do recurso de Print Screen, para o corpo do trabalho
\end{abstract}

Vídeo sobre o pronunciamento de George Lakoff: George Lakoff on The political mind. Disponível em:

http://library.fora.tv/2008/06/20/George_Lakoff_on_The_Political_Mind (último acesso em 20/07/2018).

Vídeos consultados para capturas de tela e obtenção de imagens (todos os links verificados em 21/02/2019):

Death Note - https://www.youtube.com/watch?v=ZaXnHluLPYs

Dragon Age: Origins - https://www.youtube.com/watch?v=m0u1Ww0eOP0

Red Dead Redemption II - https://www.youtube.com/watch?v=MBd0NOFCUgE

The Witcher III: Wild Hunt - https://www.youtube.com/watch?v=mBiWW_ouolk

https://www.youtube.com/watch?v=EMvqpqKpVO8

https://www.youtube.com/watch?v=9bzHCOwB5jE

https://www.youtube.com/watch?v=zjZ1QpbT58I

https://www.youtube.com/watch?v=unFBET9spIc

https://www.youtube.com/watch?v=fvqWtkMwvsY

https://www.youtube.com/watch?v=1v9ge05C5WY

https://www.youtube.com/watch?v=4Q-r0axdnjU

https://www.youtube.com/watch?v=TwIB-OdXMCY

Vingadores, era de Ultron - https://www.youtube.com/watch?v=NtVBqsgueRs 
As imagens obtidas de Runescape são capturas de tela do computador pessoal.

\section{Anexo B: Resumo da história dos jogos eletrônicos analisados no capítulo 1}

\section{Colossal Cave Adventure}

Colossal Cave Adventure (also known as ADVENT, Colossal Cave, or Adventure) is a text adventure game, developed between 1975-1977, by Will Crowther for the PDP10 mainframe. The game was expanded upon in 1977, with help from Don Woods, and other programmers created variations on the game and ports to other systems in the following years.

In the game, the player controls a character through simple text commands to explore a cave rumored to be filled with wealth. Players earn predetermined points for acquiring treasure and escaping the cave alive, with the goal to earn the maximum number of points offered. The concept bore out from Crowther's background as a caving enthusiast, with the game's cave structured loosely around the Mammoth Cave system in Kentucky.

Colossal Cave Adventure is the first known work of interactive fiction and, as the first text adventure game, is considered the precursor for the adventure game genre. Colossal Cave Adventure also contributed towards the role-playing and roguelike genres.

Adventure has the player's character explore a mysterious cave that is rumored to be filled with treasure and gold. To explore the cave, the player types in one- or two-word commands to move their character through the cave, interact with objects in the cave, pick up items to put into their inventory, and other actions. The program acts as a narrator, describing to the player what each location in the cave has, the results of certain actions, or if it did not understand the player's commands, asking for the player to retype their actions.

YOU ARE STANDING AT THE END OF A ROAD BEFORE A SMALL BRICK BUILDING.

AROUND YOU IS A FOREST. A SMALL STREAM FLOWS OUT OF THE BUILDING AND

DOWN A GULLY. 
go south

YOU ARE IN A VALLEY IN THE FOREST BESIDE A STREAM TUMBLING ALONG A ROCKY BED.

The program's replies are typically in a humorous, conversational tone, much as a dungeon master would use in leading players in a tabletop role-playing game. A notable example is when the player dies after falling into a pit (player's commands in lower case, and the program's reply in all-capitals).

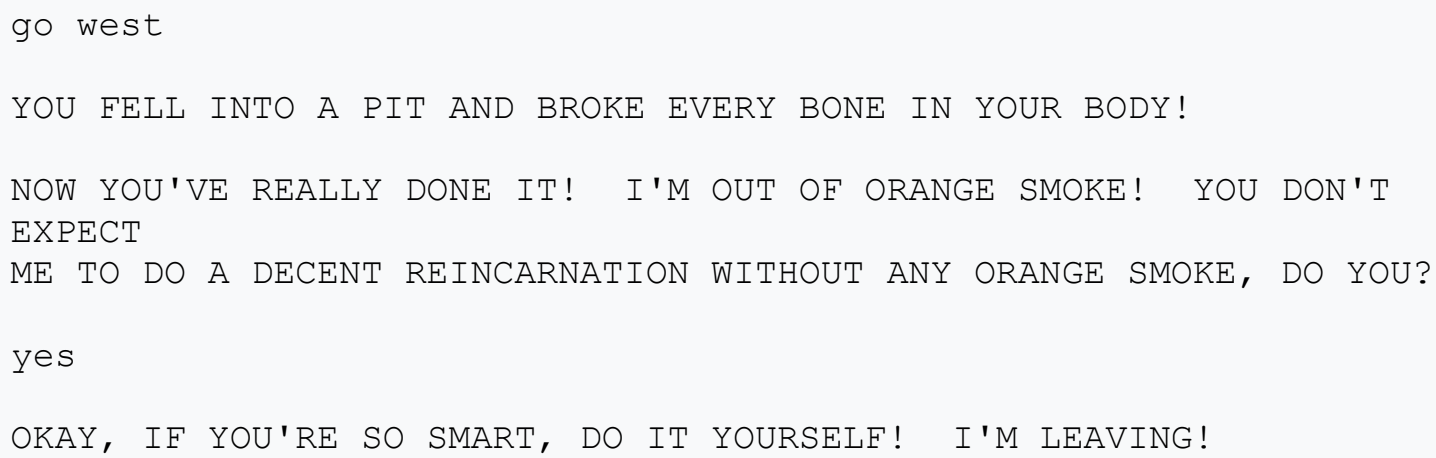

Certain actions may cause the death of the character (the player has three lives), requiring the player to start again. The game has a point system, whereby completing certain goals earns a number of predetermined points. The ultimate goal is to earn the maximum number of points (350 points), which partially correlates to finding all the treasures in the game and safely leaving the cave.

\section{Fonte}

https://en.wikipedia.org/wiki/Colossal_Cave_Adventure

\section{Adventure}

Adventure is a video game developed by Warren Robinett for the Atari VCS (later called the Atari 2600) and released in late 1979 or 1980 by Atari, Inc. The player controls a square avatar whose quest is to explore an open-ended environment to find a magical chalice and return it to the golden castle. The game world is populated by roaming enemies: three dragons that can eat the avatar and a bat that randomly steals and hides items around the game world. Adventure introduced a number of new game 
elements to console games, including a playing area that spanned several different screens and enemies that continued to move even when not displayed on the screen.

Adventure was conceived as a graphical version of the 1977 text adventure Colossal Cave Adventure. It took Warren Robinett approximately one year to design and code the game, during which time he had to overcome a variety of technical limitations in the Atari 2600 console hardware, as well as difficulties with management within Atari. In this game, he introduced the first widely known video game Easter egg: a secret room containing text crediting himself for the game's creation.

Adventure received mostly positive reviews at the time of its release and has continued to be viewed positively in the decades since, often named as one of the industry's most influential titles. It is considered the first action-adventure and console fantasy game, and inspired other titles in the genres. More than one million cartridges of Adventure were sold, and the game has been included in numerous Atari 2600 game collections for modern computer hardware. The game's prototype code was used as the basis for the 1979 Superman game, and a planned sequel eventually formed the basis for the Swordquest games. The Easter egg concept pioneered by the game has transcended video games and entered popular culture.

In Adventure, the player's goal is to recover the Enchanted Chalice that an evil magician has stolen and hidden in the kingdom and return it to the Golden Castle. The kingdom includes two other castles (White and Black) and various obstacles and mazes within them. Furthermore, the kingdom is guarded by three dragons: Yorgle (yellow dragon), Grundle (green dragon), and Rhindle (red dragon who moves much faster than the other two), that protect various items in the game and will try to chase and eat the player's avatar. There is also a bat that can roam across the kingdom freely, carrying a single item (which can include the chalice or a dragon) around; the bat was to be named Knubberrub but the name did not make it into the manual. The bat has two states, agitated and nonagitated; when in the agitated state, the bat will either pick up or swap what it currently carries with an object in the present room, eventually returning to the non-agitated state where it will not pick up an object. The bat continues to fly around even if not present on the player's current screen and may continue moving or swapping around objects.

The player's avatar is a simple square shape that can move within and between rooms, each represented by a single screen. While Robinett originally intended for all rooms to 
be bidirectionally connected, a few such connections (including one inside the White Castle) were unidirectional, which he considered to be bugs. Such problems were explained away as "bad magic" in the game's manual. The player's goal is to find objects to help defeat the dragons and recover the Chalice. These include various keys that open the castles, a magnet that pulls items towards the player, a magic bridge that the player can use to cross certain obstacles, and a sword which can be used to defeat the dragons. Only one object can be carried at a time. The player can be eaten by a dragon if it is caught in its "bite" cycle, at which point the avatar is stuck in the dragon's stomach. At this point, the player can opt to restore their avatar's life instead of completely restarting the game, reappearing at the Golden Castle while leaving all objects where they were last left, but this will also regenerate any dragon previously killed as well. The ability to reset the player's avatar without resetting the entire game is considered one of the earliest examples of a "continue game" option in video games.

The game offers three different skill levels. Level 1 is the easiest, as it uses a simplified room layout and doesn't include the White Castle, bat, Rhindle the red dragon, nor invisible mazes. Level 2 is the full version of the game, with the various objects appearing in set positions at the start of the game. Level 3 is similar to Level 2, but the location of the objects is randomized to provide a more challenging game. In addition, the player can use the difficulty switches on the Atari 2600 to further control the game's difficulty by affecting the behavior of the dragons: one switch controls the dragons' bite speed, and one causes them to flee when the player is wielding the sword.

\section{Fonte}

https://en.wikipedia.org/wiki/Adventure_(Atari_2600)

\section{Dragon Age: Origins}

Dragon Age: Origins is a role-playing game developed by BioWare and published by Electronic Arts. It is the first game in the Dragon Age franchise, and was released for Microsoft Windows, PlayStation 3, and Xbox 360 in November 2009, and for Mac OS X in December 2009. Set in the fictional kingdom of Ferelden during a period of civil strife, the game puts the player in the role of a warrior, mage, or rogue coming from an elven, human, or dwarven background. The player character is recruited into the Grey 
Wardens, an ancient order that stands against demonic forces known as "Darkspawn", and is tasked with defeating the Archdemon that commands them and ending their invasion. The game is played from a third-person perspective that can be shifted to a topdown perspective. Throughout the game, players encounter various companions, who play major roles in the game's plot and gameplay.

BioWare described Dragon Age: Origins as a "dark heroic fantasy" set in a unique world, and a spiritual successor to their previous Baldur's Gate and Neverwinter Nights franchises. Its setting was inspired by The Lord of the Rings and A Song of Ice \& Fire, and was described by BioWare as a mix between high fantasy and low fantasy. Development of the game began in 2002 and BioWare employed more than 144 voiceactors, and hired Inon Zur to compose the game's music. The development of the game's console versions was outsourced to Edge of Reality.

Origins received critical acclaim upon release, with praise mostly directed at its story, setting, characters, music and combat system. It sold more than 3.2 million copies and 1 million pieces of downloadable content. Its multiple year-end accolades included Game of the Year and Best Role-playing awards from several gaming publications. BioWare released several instances of downloadable content after the game's initial launch, an expansion pack for the game titled Awakening in March 2010, and two sequels, Dragon Age II and Dragon Age: Inquisition, were released in 2011 and 2014 respectively.

Fonte

https://en.wikipedia.org/wiki/Dragon_Age\%3A_Origins

\section{The Witcher III: Wild Hunt}

The Witcher 3: Wild Hunt is a 2015 action role-playing game developed and published by CD Projekt and based on The Witcher series of fantasy novels by Andrzej Sapkowski. It is the sequel to the 2011 game The Witcher 2: Assassins of Kings, played in an open world with a third-person perspective. Players control protagonist Geralt of Rivia, a monster hunter (known as a witcher) who is looking for his missing adopted daughter on the run from the Wild Hunt, an otherworldly force determined to capture her and use her powers. Players battle the game's many dangers with weapons and magic, interact with 
non-player characters, and complete main-story and side quests to acquire experience points and gold, which are used to increase Geralt's abilities and purchase equipment. Its central story has several endings, determined by the player's choices at certain points in the game.

Development began in 2011 and lasted for three and a half years. Voice recording took more than two and a half years. The writing was infused with realistic aspects such as moral ambiguity in an attempt to avoid simplification, impart authenticity, and reflect Sapkowski's novels. Central and Northern European cultures formed the basis of the game's world. REDengine 3 enabled the developer to create a complex story without compromising the game's open world. The music was composed by Marcin Przybyłowicz and performed by the Brandenburg State Orchestra.

The Witcher 3: Wild Hunt was released for Microsoft Windows, PlayStation 4, and Xbox One in May 2015, with a Nintendo Switch version released in October 2019. The game received critical acclaim, with praise for its gameplay, narrative, world design, combat, and visuals, although it received minor criticism due to technical issues. It received numerous Game of the Year awards and has been cited as one of the greatest video games ever made. It was also a commercial success, shipping more than 20 million copies by June 2019. Two expansions were also released to critical acclaim: Hearts of Stone and Blood and Wine. A Game of the Year edition was released in August 2016, with the base game, expansions, and all downloadable content.

Fonte

https://en.wikipedia.org/wiki/The_Witcher_3:_Wild_Hunt

\section{The Elder Scrolls V: Skyrim}

The Elder Scrolls V: Skyrim is an action role-playing video game developed by Bethesda Game Studios and published by Bethesda Softworks. It is the fifth main installment in The Elder Scrolls series, following The Elder Scrolls IV: Oblivion, and was released worldwide for Microsoft Windows, PlayStation 3, and Xbox 360 on November 11, 2011. The game's main story revolves around the player's character, the Dragonborn, quest to defeat Alduin the World-Eater, a dragon who is prophesied to destroy the world. The game is set 200 years after the events of Oblivion and takes place in Skyrim, the 
northernmost province of Tamriel. Over the course of the game, the player completes quests and develops the character by improving skills. The game continues the openworld tradition of its predecessors by allowing the player to travel anywhere in the game world at any time, and to ignore or postpone the main storyline indefinitely.

Skyrim was developed using the Creation Engine, rebuilt specifically for the game. The team opted for a unique and more diverse open world than Oblivion's Imperial Province of Cyrodiil, which game director and executive producer Todd Howard considered less interesting by comparison. The game was released to critical acclaim, with reviewers particularly mentioning the character advancement and setting, and is considered to be one of the greatest video games of all time. Nonetheless it received some criticism, predominantly for its melee combat and numerous technical issues present at launch. The game shipped over seven million copies to retailers within the first week of its release, and over 30 million copies on all platforms as of November 2016, making it one of the best-selling video games in history.

Three downloadable content (DLC) add-ons were released-Dawnguard, Hearthfire, and Dragonborn - which were repackaged into The Elder Scrolls V: Skyrim - Legendary Edition and released in June 2013. The Elder Scrolls V: Skyrim-Special Edition is a remastered version of the game released for Windows, Xbox One, and PlayStation 4 in October 2016. It includes all three DLC expansions and a graphical upgrade, along with additional features such as modding capabilities on consoles. Versions were released in November 2017 for the Nintendo Switch and PlayStation VR, and a stand-alone virtual reality (VR) version for Windows was released in April 2018.

\section{Fonte}

https://en.wikipedia.org/wiki/The_Elder_Scrolls_V:_Skyrim

\section{Runescape}

RuneScape, sometimes referred to as RuneScape 3, is a fantasy massively multiplayer online role-playing game (MMORPG) developed and published by Jagex, first released in January 2001. RuneScape was originally a browser game built with the Java programming language, but was largely replaced by a standalone $\mathrm{C}++-$ coded 
client in 2016. The game has had over 200 million accounts created and is recognized by the Guinness World Records as the world's largest and most-updated free MMORPG.

RuneScape takes place in the world of Gielinor, a medieval fantasy realm divided into different kingdoms, regions, and cities. Players can travel throughout Gielinor via a number of methods including on foot, magical spells, or charter ships. Each region offers different types of monsters, resources, and quests to challenge players. The game's fictional universe has also been explored through a tie-in video game on another of its maker's websites, FunOrb, Armies of Gielinor, and the novels Betrayal at Falador, Return to Canifis, and Legacy of Blood.

Players are represented in the game with customizable avatars. RuneScape does not follow a linear storyline; rather, players set their own goals and objectives. Players can choose to fight non-player character (NPC) monsters, complete quests, or increase their experience in the available skills. Players interact with each other through trading, chatting, or by participating in mini-games and activities, some of which are competitive or combative in nature, while others require cooperative or collaborative play.

The first public version of RuneScape was released in January 2001 in beta form, with Jagex as its copyright holder being formed later that year. As the game's popularity grew, the game engine was rewritten and released as RuneScape 2, with the original version of the game being renamed RuneScape Classic. The third iteration of the game, known as RuneScape 3, was released in July 2013. Old School RuneScape, a separate, older version of the game dating from August 2007 was released in February 2013, and is maintained alongside the original client. It was announced that mobile ports of both versions of RuneScape would be released for Android and iOS devices in 2018.

\section{Fonte}

https://en.wikipedia.org/wiki/RuneScape 


\section{Anexo C: Resumo da história dos títulos de mídia (filme, mangá/anime, jogos eletrônicos) analisados no capítulo 3}

\section{Vingadores: Era de Ultron}

Avengers: Age of Ultron is a 2015 American superhero film based on the Marvel Comics superhero team the Avengers, produced by Marvel Studios and distributed by Walt Disney Studios Motion Pictures. It is the sequel to 2012's The Avengers and the eleventh film in the Marvel Cinematic Universe (MCU). The film was written and directed by Joss Whedon and features an ensemble cast that includes Robert Downey Jr., Chris Hemsworth, Mark Ruffalo, Chris Evans, Scarlett Johansson, Jeremy Renner, Don Cheadle, Aaron Taylor-Johnson, Elizabeth Olsen, Paul Bettany, Cobie Smulders, Anthony Mackie, Hayley Atwell, Idris Elba, Stellan Skarsgård, James Spader, and Samuel L. Jackson. In the film, the Avengers fight Ultron, an artificial intelligence obsessed with causing human extinction.

The sequel was announced in May 2012, after the successful release of The Avengers. Whedon, the director of the first film, was brought back on board in August and a release date was set. By April 2013, Whedon had completed a draft of the script, and casting began in June with the re-signing of Downey. Second unit filming began in February 2014 in South Africa with principal photography taking place between March and August 2014. The film was primarily shot at Shepperton Studios in Surrey, England, with additional footage filmed in Italy, South Korea, Bangladesh, New York City, and various locations around England. While in post-production, the film was converted to 3D and over 3,000 visual effects shots were added. With an estimated net production budget of $\$ 365$ million, it is the second most expensive film ever made.

Avengers: Age of Ultron premiered in Los Angeles on April 13, 2015, and was released in the United States on May 1, 2015, in 3D and IMAX 3D. The film received generally positive reviews from critics and grossed over $\$ 1.4$ billion worldwide, becoming the fourth-highest-grossing film of 2015 as well as the fifth-highest-grossing film at the time. Two sequels, Avengers: Infinity War and Avengers: Endgame, were released in April 2018 and April 2019, respectively. 
In the Eastern European country of Sokovia, the Avengers-Tony Stark, Steve Rogers, Thor, Bruce Banner, Natasha Romanoff, and Clint Barton—raid a Hydra facility commanded by Baron Wolfgang von Strucker, who has been experimenting on humans using the scepter previously wielded by Loki. They encounter two of Strucker's test subjects - twins Pietro, who has superhuman speed, and Wanda Maximoff, who has telepathic and telekinetic abilities_ and apprehend Strucker, while Stark retrieves Loki's scepter.

Stark and Banner discover an artificial intelligence within the scepter's gem, and secretly decide to use it to complete Stark's "Ultron" global defense program. The unexpectedly sentient Ultron, believing he must eradicate humanity to save Earth, eliminates Stark's A.I. J.A.R.V.I.S. and attacks the Avengers at their headquarters. Escaping with the scepter, Ultron uses the resources in Strucker's Sokovia base to upgrade his rudimentary body and build an army of robot drones. Having killed Strucker, he recruits the Maximoffs, who hold Stark responsible for their parents' deaths by his company's weapons, and goes to the base of arms dealer Ulysses Klaue in Johannesburg to obtain Wakandan vibranium. The Avengers attack Ultron and the Maximoffs, but Wanda subdues them with haunting visions, causing Banner to turn into the Hulk and rampage until Stark stops him with his anti-Hulk armor.

A worldwide backlash over the resulting destruction, and the fears Wanda's hallucinations incited, send the team into hiding at a safe house. Thor departs to consult with Dr. Erik Selvig on the apocalyptic future he saw in his hallucination, while Nick Fury arrives and encourages the team to form a plan to stop Ultron. In Seoul, Ultron uses Loki's scepter to enslave the team's friend Dr. Helen Cho. They use her synthetic-tissue technology, vibranium, and the scepter's gem to craft a new body. As Ultron uploads himself into the body, Wanda is able to read his mind; discovering his plan for human extinction, the Maximoffs turn against Ultron. Rogers, Romanoff, and Barton find Ultron and retrieve the synthetic body, but Ultron captures Romanoff.

The Avengers fight amongst themselves when Stark and Banner secretly upload J.A.R.V.I.S. - who is still operational after hiding from Ultron inside the Internet-into the synthetic body. Thor returns to help activate the body, explaining based on his vision that the gem on its brow is the Mind Stone, one of the six Infinity Stones, the most powerful objects in existence. This "Vision" and the Maximoffs accompany the Avengers 
to Sokovia, where Ultron has used the remaining vibranium to build a machine to lift a large part of the capital city skyward, intending to crash it into the ground to cause global extinction. Banner rescues Romanoff, who awakens the Hulk for the battle. The Avengers fight Ultron's army while Fury arrives in a Helicarrier with Maria Hill, James Rhodes and S.H.I.E.L.D. agents to evacuate civilians. Pietro dies when he shields Barton from gunfire, and a vengeful Wanda abandons her post to destroy Ultron's primary body, which allows one of his drones to activate the machine. The city plummets, but Stark and Thor overload the machine and shatter the landmass. In the aftermath, the Hulk, unwilling to endanger Romanoff by being with her, departs in a Quinjet, while Vision confronts and seemingly destroys Ultron's last remaining body.

Later, with the Avengers having established a new base run by Fury, Hill, Cho, and Selvig, Thor returns to Asgard to learn more about the forces he suspects have manipulated recent events. As Stark leaves and Barton retires, Rogers and Romanoff prepare to train new Avengers: Rhodes, Vision, Sam Wilson, and Wanda.

In a mid-credits scene, Thanos, dissatisfied by the failures of his pawns, dons a gauntlet and vows to retrieve the Infinity Stones himself.

Fonte

https://en.wikipedia.org/wiki/Avengers:_Age_of_Ultron

\section{Death Note}

Death Note (Japanese: デスノート Hepburn: Desu Nōto) is a Japanese manga series written by Tsugumi Ohba and illustrated by Takeshi Obata. The story follows Light Yagami, a teen genius who stumbles across a mysterious otherworldly notebook: the "Death Note", which belonged to the Shinigami Ryuk, and grants the user the supernatural ability to kill anyone whose name is written in its pages. The series centers around Light's subsequent attempts to use the Death Note to carry out a world-wide massacre of individuals whom he deems morally unworthy of life to change the world into a utopian society without crime, using the alias of a god-like vigilante named "Kira" ("キラ", the Japanese transliteration of the English word: killer) and the subsequent efforts of an elite task-force of law enforcement officers, consisting of members of the 
Japanese police force, led by L, an enigmatic international detective whose past is shrouded in mystery, to apprehend him and end his reign of terror.

Death Note was first serialized in Shueisha's manga magazine Weekly Shōnen Jump from December 2003 to May 2006. The 108 chapters were collected and published into 12 tankōbon volumes between April 2004 and July 2006. An anime television adaptation aired in Japan from October 3, 2006, to June 26, 2007. Composed of 37 episodes, the anime was developed by Madhouse and directed by Tetsurō Araki. A light novel based on the series, written by Nisio Isin, was also released in 2006. Additionally, various video games have been published by Konami for the Nintendo DS. The series was adapted into three live action films released in Japan on June 17, 2006, November 3, 2006, and February 2, 2008, and a television drama in 2015. A miniseries entitled Death Note: New Generation and a fourth film were released in 2016. An American film adaptation was released on Netflix on August 24, 2017.

Death Note media is licensed and released in North America by Viz Media, with the exception of the video games and soundtracks. The episodes from the anime first appeared in North America as downloadable from IGN, before Viz Media licensed it and it aired on YTV's Bionix anime block in Canada and on Adult Swim in the United States with a DVD release following. The live-action films briefly played in certain North American theaters in 2008, before receiving home video releases. In 2015, the collected volumes of the Death Note manga had over 30 million copies in circulation.

In Tokyo, an intelligent yet disaffected high-school student named Light Yagami finds the "Death Note", a mysterious black notebook which can kill anyone as long as the user knows both the target's name and face. After verifying that the notebook works and initially being terrified of its god-like abilities, Light begins to consider the possibilities of the Death Note's abilities and sets out to create a utopian world without crime, killing numerous high-profile Japanese criminals, before eventually targeting international criminals and felons around the world. Eventually, Light is visited by Ryuk, a "Shinigami," beings inspired by the Japanese god of death and the Death Note's previous owner, who dropped the notebook into the human world out of boredom. Ryuk, who is invisible to anyone who has not touched the Death Note, is amused by Light's actions and serves as Light's companion. 
As numerous criminals and convicts around the world begin to die of inexplicable freak accidents and heart attacks, the global media begin to believe that a single mastermind is responsible for the mysterious murders and name him "Kira", the Japanese transliteration of the word: "killer", who is both feared and beloved by the public and law enforcement agencies. Hoping to apprehend Kira, Interpol requests the assistance of an enigmatic and highly esteemed international consulting detective, known as L, who has cracked numerous crime cases around the world, to assist them in the investigation. After deducing that Kira is based in Japan, L stages a TV broadcast in which he tricks Light into revealing that he is in the Kanto region of Japan, by manipulating him to kill a decoy. Humiliated, Light vows to kill L, whom he views as obstructing his plans. L quickly deduces that Kira has inside knowledge of the Japanese police's investigation, led by Light's father, Soichiro Yagami. Under the suspicion that "Kira" could have familial connections with the members of the "Kira" investigation, L assigns a team of FBI agents to monitor the families of those connected with the investigation, but Light outmaneuvers and kills them all. Nonetheless, L picks up enough hints to designate Light as the prime suspect. Around this time, Light graduates from high school to college. L recruits Light into the Kira Task Force, both trying to get the other to reveal crucial info.

At this point, a famous model/actress named Misa Amane gains a second Death Note from a Shinigami named Rem. Misa makes a deal with Rem for Shinigami eyes, which allows her to kill knowing only the face at the cost of half her lifespan. Misa commits numerous murders, sends taped recordings to the police, and eventually uncovers Light's identity as the original Kira. Infatuated with Light, she demands Light be her boyfriend. Although he does not love Misa, Light agrees, intending to use Misa's Shinigami eyes to discern L's true name. However, before she can do so, L deduces that Misa is likely the second Kira and detains her. Rem, who has feelings for Misa, threatens to kill Light if he does not find a way to save Misa. Light arranges a scheme in which he and Misa temporarily lose their memories of the Death Note, and has Rem pass the Death Note to a less morally driven individual, Kyosuke Higuchi of the Yotsuba Group. Now with no knowledge of the Death Note, Light wholeheartedly joins the investigation. Together, Light and L deduce Higuchi's identity, arrest him, and discover the existence of the Death Notes and the Shinigami. When they touch the Death Note, Light and Misa regain their memories, and Light kills Higuchi with a piece of the Death Note, regaining possession of the book. However, L casts suspicion on Misa, forcing Rem to murder L to save her. 
Rem dies in the process, as it is forbidden for Shinigami to prevent humans from dying. The task force agrees to cover up L's death and appoint Light as the new L. The investigation stalls as a result.

Four years later, crime rates worldwide have massively dropped, but cults have arisen which adore Kira. Two intelligent young men, who were raised as potential successors to L, are revealed: Near and Mello. Both are aware that L is dead, and thus consider Light, the current L, a prime suspect. Mello, along with the Mafia's assistance, kidnaps Light's sister, resulting in his father's death during the rescue mission. As suspicion starts to fall again on Misa, Light passes Misa's Death Note to a fervent supporter of Kira, Teru Mikami. He also appoints a well-known newscaster, Kiyomi Takada as Kira's public spokesperson. Realizing that Takada is connected to Kira, Mello kidnaps her. Takada kills Mello with a hidden page of the Death Note but is killed by Light in order to dispel suspicions. Shortly after, Near deduces Mikami's connection to Kira and arranges a meeting between Light and the current Kira Task Force members. Light seizes the chance to have Mikami kill Near as well as all the task force members. However, Mikami's Death Note fails to work. It is revealed that Near had replaced Mikami's Death Note with a decoy. Perusing the names Mikami had written down, only Light's is missing, which proves Light is Kira. A scuffle breaks out during which Light is grievously wounded. Ryuk, realizing that Light will spend the rest of his life in prison, writes down Light's name in his Death Note - as he had promised to do at the beginning of the story.

Fonte

https://en.wikipedia.org/wiki/Death_Note

\section{Red Dead Redemption 2}

Red Dead Redemption 2 is an action-adventure game developed and published by Rockstar Games. It was released for the PlayStation 4 and Xbox One in October 2018, and for Microsoft Windows in November 2019. The game is the third entry in the Red Dead series and is a prequel to the 2010 game Red Dead Redemption. The story is set in 1899 in a fictionalized representation of the Western, Midwestern and Southern United States and follows outlaw Arthur Morgan, a member of the Van der Linde gang. Arthur must deal with the decline of the Wild West whilst attempting to survive against 
government forces, rival gangs, and other adversaries. The story also follows fellow gang member John Marston, the protagonist of Red Dead Redemption.

The game is presented through both first and third-person perspectives, and the player may freely roam in its interactive open world. Gameplay elements include shootouts, heists, hunting, horseback riding, interacting with non-player characters (NPCs), and maintaining the character's honor rating through moral choices and deeds. A bounty system similar to the "wanted" system from the Grand Theft Auto franchise governs the response of law enforcement and bounty hunters to crimes committed by the player. Red Dead Online, the online multiplayer mode of the game, was released as a beta version in November 2018 before a full release in May 2019.

The game's development began soon after Red Dead Redemption's release and was shared between all of Rockstar's studios worldwide. The development team drew influence from real locations as opposed to film or art, focused on creating an accurate reflection of the time with the game's characters and world. The game was Rockstar's first built specifically for the consoles, having tested their technical capabilities while porting Grand Theft Auto V to the platforms. The game's soundtrack features an original score composed by Woody Jackson and several vocal tracks produced by Daniel Lanois. Broadly anticipated and marketed before release, Red Dead Redemption 2 broke several records and had the second-biggest launch in the history of entertainment, generating $\$ 725$ million in sales from its opening weekend and exceeding the lifetime sales of Red Dead Redemption in two weeks. It received widespread critical acclaim, with praise directed at its story, characters, open world, graphics, and considerable level of detail. Considered as an example of video games as an art form, it won year-end accolades including Game of the Year awards from several gaming publications. It is among the best-selling video games of all time with over 26.5 million copies shipped.

\section{Fonte}

https://en.wikipedia.org/wiki/Red_Dead_Redemption_2 